The London School of Economics and Political Science

\title{
Risen from Chaos: \\ the development of modern education in China, 1905-1948
}

Pei Gao

A thesis submitted to the Department of Economic History of the London School of Economics for the degree of Doctor of Philosophy

London, March 2015 


\section{Declaration}

I certify that the thesis I have presented for examination for the MPhil/PhD degree of the London School of Economics and Political Science is solely my own work other than where I have clearly indicated that it is the work of others (in which case the extent of any work carried out jointly by me and any other person is clearly identified in it).

The copyright of this thesis rests with the author. Quotation from it is permitted, provided that full acknowledgement is made. This thesis may not be reproduced without my prior written consent.

I warrant that this authorisation does not, to the best of my belief, infringe the rights of any third party.

I declare that my thesis consists of 72182 words.

I can confirm that my thesis was copy edited for conventions of language, spelling and grammar by Eve Richard. 


\begin{abstract}
My $\mathrm{PhD}$ thesis studies the rise of modern education in China and its underlying driving forces from the turn of the $20^{\text {th }}$ century. It is motivated by one sweeping educational movement in Chinese history: the traditional Confucius teaching came to an abrupt end, and was replaced by a modern and national education model at the turn of the 20th century. This thesis provides the first systematic quantitative studies that examine the rise of education through the initial stage of its development.

It mainly contains three analytical parts. The first one sets out the jourey toward the birth of the first modern education system, and generalized the main virtues and progresses it brought to China. The second section provides long-term estimates on how much education progressed through 20th century based on a rich variety of indicators: literacy rate, enrolment ratio, and more importantly -- human capital stock (average years of schooling). This exercise allows putting Chinese accomplishments in education into international perspective. The last Chapter of this thesis tackles one hotly debated question that 'what factors drove the rise of mass schooling (primary education)?' Given its political turmoil and economic backwardness, the expansion of modern primary schooling that was mainly driven by increasing public efforts seems puzzling. What contributed to mass education's noteworthy diffusion in China? Based on a dataset that covers more than one thousand counties, we find that economic factors have little power in explaining the variations in educational outcomes. In contrast, both informal practice of governance imposed by gentry (one important social group in Chinese history) and regional political stability presented their critical importance. The findings of this section not only contribute to pin down determinants of education expansion, but also shed lights on a growing literature stressing the importance of informal institution in providing public goods in non-democratic societies.
\end{abstract}




\section{Acknowledgement}

Obtaining a doctoral degree is not solely an intellectual challenge, but also a physiological task. Luckily enough, along my journey towards a $\mathrm{PhD}$, I have been surrounded by a group of intelligent, loving and generous people, with whose help and support, I cannot ask for a better five years in London.

First and foremost, I am extremely grateful to my supervisors, Dr. Chris Minns and Dr. Debin Ma, whose encouragement and guidance enabled me to complete this thesis. I am also thankful for Professor Peter Lindert who offered generous help and guidance on my thesis at its last stage. I am equally grateful for the head of Economic History Department, Professor Max Schulze, the director of PhD programme, Professor Oliver Volckart and Professor Joan Roses, their solid support at some critical moments gives me the chance to finish this thesis.

I would like to thank my parents who have been giving me their unconditional love. Without their unwavering trust and support, I will not be the person I am today. I also need to thank my peers and friends in the department who made my days in LSE more colourful. Furthermore, I'm truly blessed to have a group of loving friends who have been there for me through ups and downs. Lastly, I also want to thank Yu-Hsiang Lei's patience and support, who probably never intended to know so much about the education development in China. 


\section{Table of Contents}

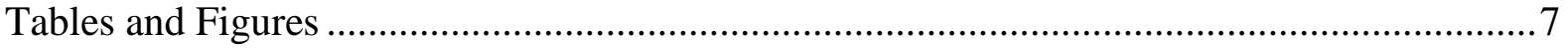

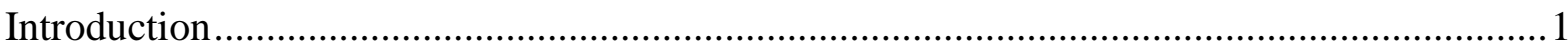

Chapter 1 : Setting the scene: political and economic background of a modern education

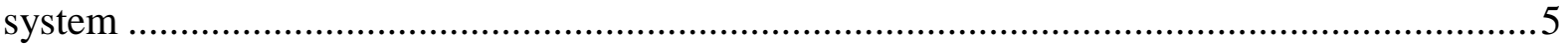

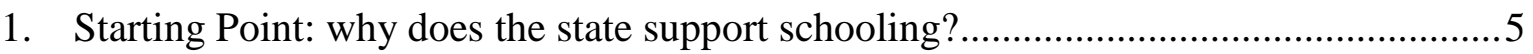

2. Economic and political foundation of educational development in the early $20^{\text {th }}$ century 9

2.1 Historical Background: The awakening Empire ....................................................

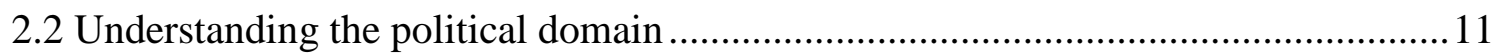

2.3 Understanding key features of the Chinese economy ...........................................22

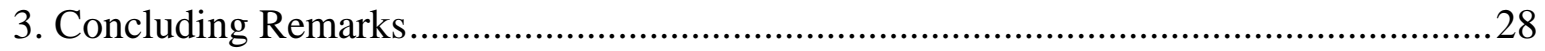

Chapter 2 : The journey: towards a modern education system in China ................................29

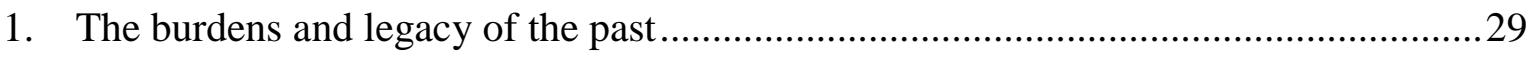

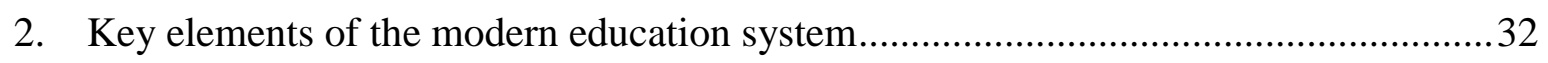

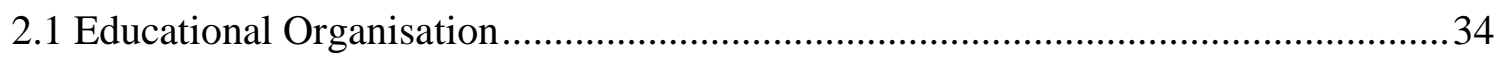

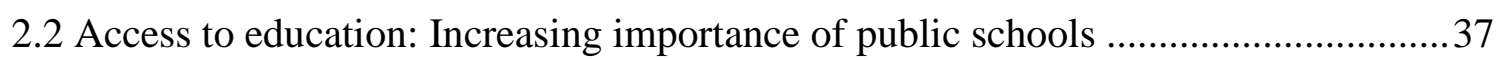

2.3 Decentralised Structure of the new education system ............................................ 40

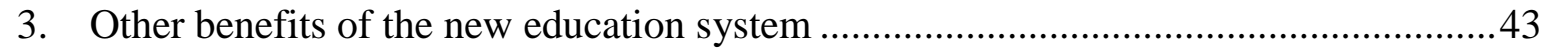

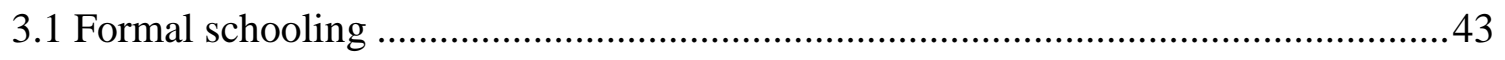

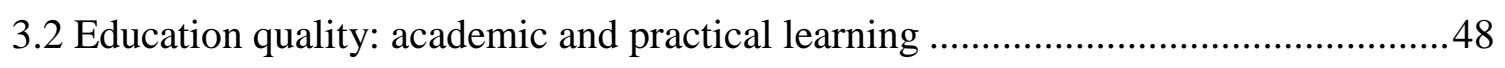

3.3 Equal access to schooling: gender neutrality ...................................................... 49

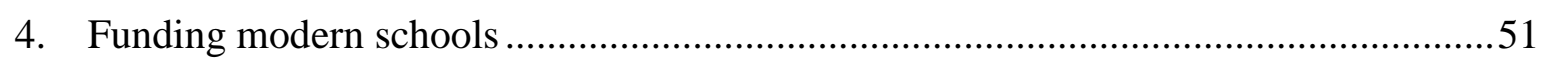

4.1 Weak fiscal capacity and the implicit fiscal relationship in China ...........................52

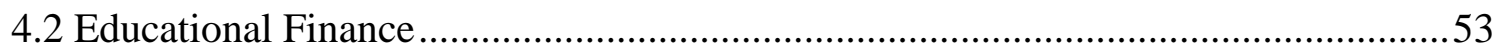

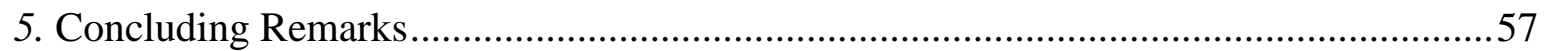

Chapter 3 : Long-term Trends in Schooling: Measuring educational development ................59

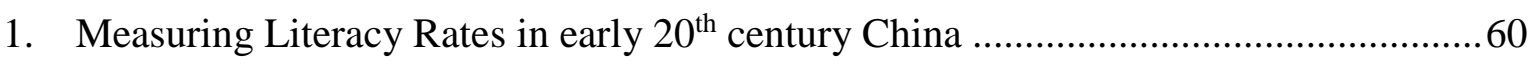

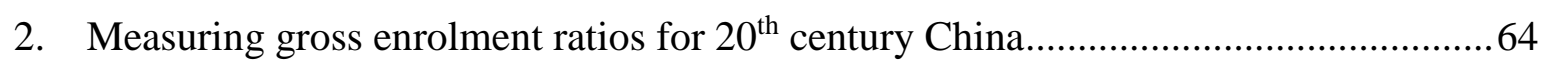

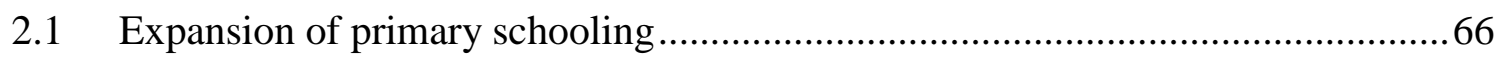

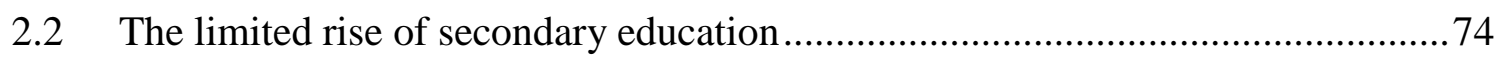

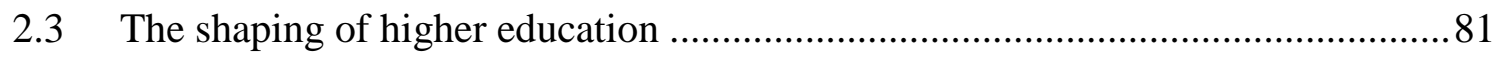

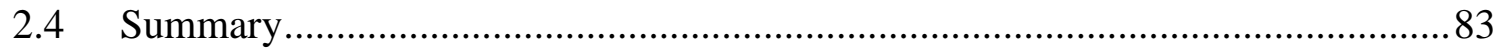

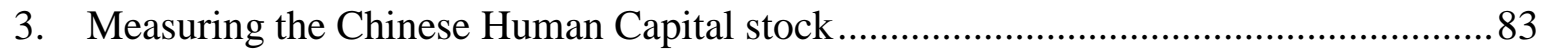

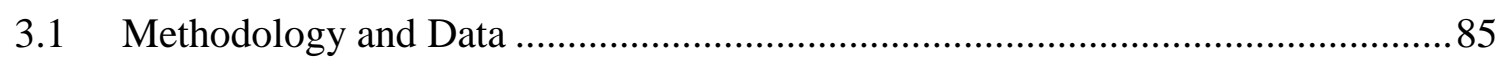

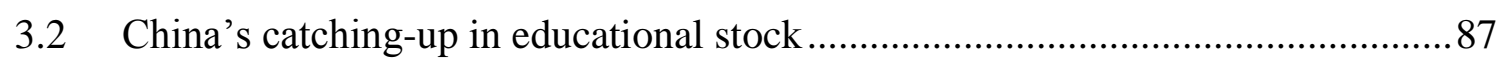

3.3 Complementary evidence using individual survey data ......................................94 
4. Concluding remarks

Chapter 4 : Risen from Chaos: What drove the spread of Modern Primary Schooling in China

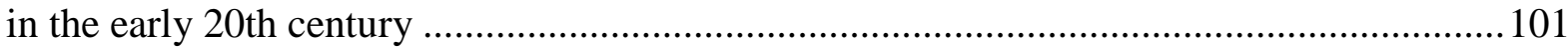

1. Conceptual framework: what are the driving forces of education? .............................103

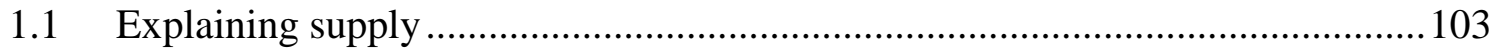

1.2 China's exogenous education supply shock in the early $20^{\text {th }}$ century ...................... 106

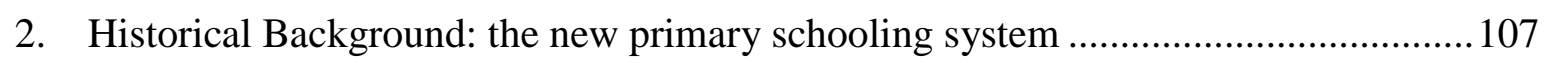

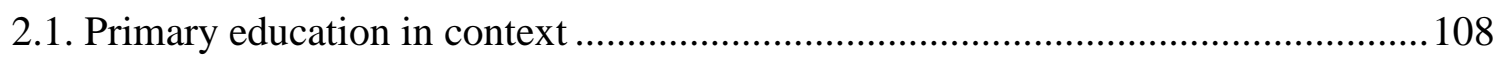

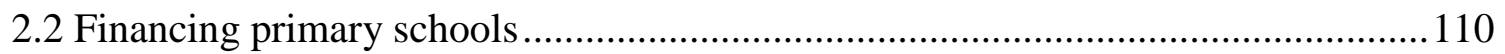

3. Was the prosperity the main determinant of the rising mass schooling in China? .....115

4. Interest groups on education provision .................................................................... 119

4.1 Was the commitment from govern the driving force? ......................................... 119

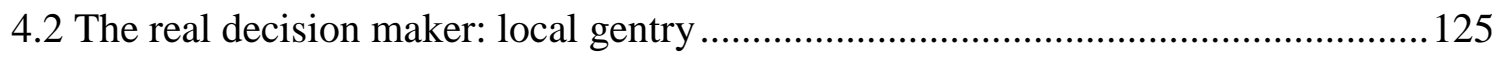

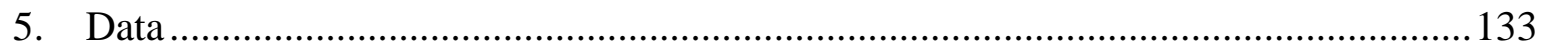

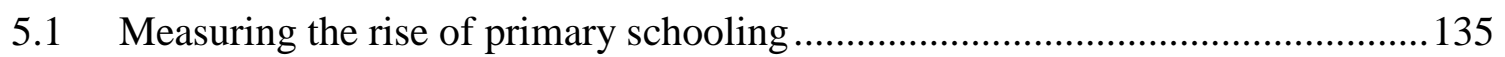

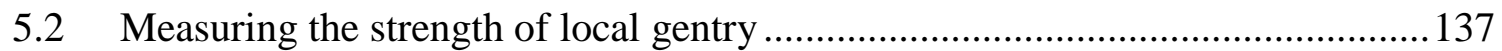

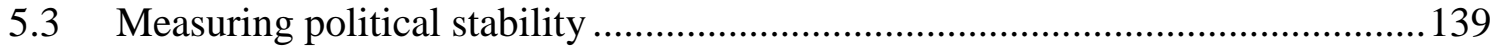

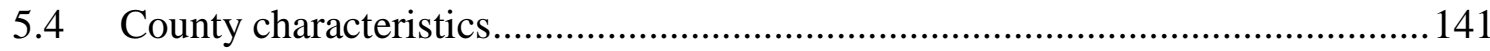

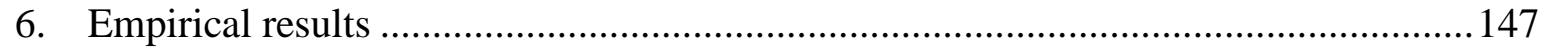

6.1 Local gentry and the expansion of schooling ............................................... 147

6.2 Instrumented evidence: the gentry's effect on primary schooling ......................153

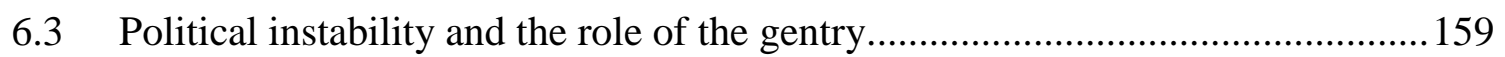

6.4 Economic outcomes and schooling development.............................................. 161

6.5 Alternative influencing mechanisms of the gentry: scholar culture? .................. 165

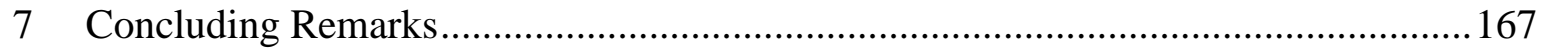

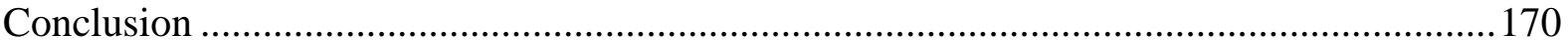

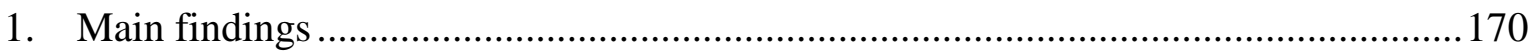

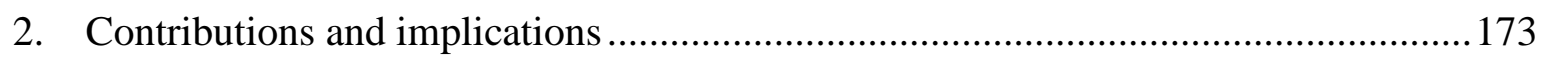

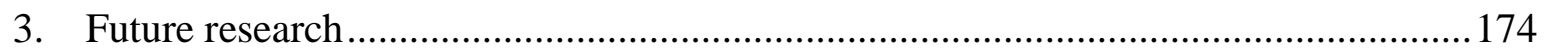

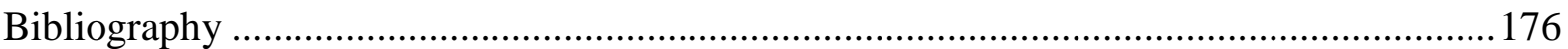

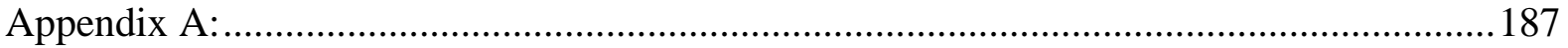

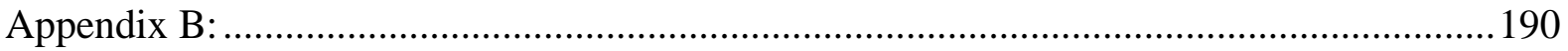

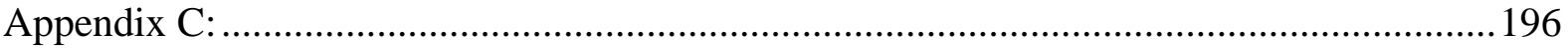




\section{Tables and Figures}

\section{Tables:}

Table 1.1: Timeline of Chinese history \& educational progress............................... 10

Table 1.2: The formal government structure of China (both late Qing and

Republican)

Table 1.3: Labour force and GDP composition of China, in $1933 \ldots \ldots \ldots \ldots \ldots \ldots \ldots . .25$

Table 2.1: Education Acts passed through the first part of the $20^{\text {th }}$ century ............... 34

Table 2.2: School by management, 1910s-1940s......................................................... 41

Table 2.3: The difference between traditional and modern education.......................43

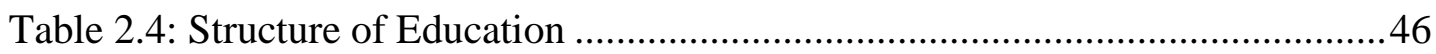

Table 2.5: Educational background of primary school teachers, 1946 ......................47

Table 2.6: Regulatory models for primary school curricula (\%) .............................49

Table 2.7: Male/Female student ratio in secondary schools (1912-1946) ..................51

Table 2.8: Education and military expenditure in central government expenditure ..54

Table 2.9: Sources of the revenue for primary education (county)............................56

Table 3.1: Modern Primary Enrolment Ratios, per 1000 population (5-14)..............69

Table 3.2: Secondary Enrolment Ratios per 1000 population .................................. 77

Table 3.3: Composition of Secondary school (general/normal/vocational)................79

Table 3.4: Regression results for the projection approach ........................................90

Table 3.5: Human capital accumulation in China $(1920-2000)$................................91

Table 3.6: Average schooling at different levels of education in China, 1950 - 2000

Table 4.1: Composition of public primary schools $(\%)$........................................... 108

Table 4.2: Composition of public primary schools by province in $1933(\%)$........... 109

Table 4.3: The difference between provincial, local and private schools .................110

Table 4.4: The revenue composition for primary education at county level (Yuan)112

Table 4.5: Statistical summary for primary schooling level by group .................... 118

Table 4.6: Turnover of county magistrates ............................................................. 123

Table 4.7: Summary statistics for dependent variables: schooling variables............ 136

Table 4.8: Summary statistics for the numbers of the gentry .................................139

Table 4.9: Summary statistics for the turnover of county magistrates...................... 140

Table 4.10: Statistical summary of control variables............................................. 146

Table 4.11: Correlation between primary schooling provision and gentry............... 149

Table 4.12: Correlation between primary schooling level and gentry .....................150

Table 4.13: Dynamic effects of local gentry on primary education......................... 152

Table 4.14: Falsification tests: the effect of instrument on other variables ............. 155

Table 4.15: Estimation results from IV strategy ................................................ 156

Table 4.16: Dynamic effect of the local gentry on primary education .....................158

Table 4.17: Robustness check using Shanxi Province ............................................. 159

Table 4.18: Dependent variable: primary enrolment ratios ..................................160

Table 4.19: Economic characteristics and primary enrolment ratios .........................163

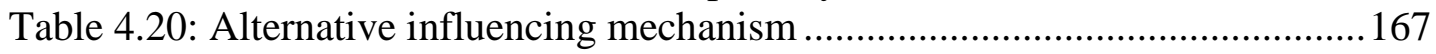




\section{Figures:}

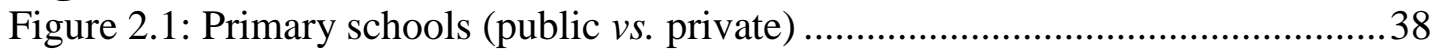

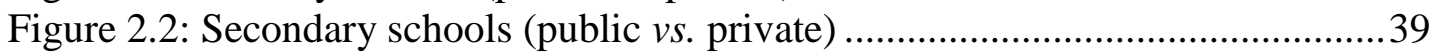

Figure 2.3: Tertiary schools (public $v s$. private) ....................................................... 39

Figure 3.1: Gross enrolment rates in modern primary education, 1900-2005 ..........67

Figure3.2: Relationship between modern primary schools and Sishu ......................72

Figure 3.3 Gross enrolment ratios in secondary education, 1907-1949.................... 76

Figure 3.4: Gross enrolment ratios in secondary schooling, 1949-2005 ...................78

Figure 3.5: Gross enrolment ratios (normal school vs. vocational school)................80

Figure 3.6: Gross enrolment ratio in tertiary education, 1912-1946 .......................81

Figure 3.7: Enrolment proportions in China (primary/secondary/tertiary) ................83

Figure 3.8: Years of schooling by birth cohorts at age 30 years .............................. 88

Figure 3.9: International comparison of educational attainment 1920- 2000).......... 93

Figure 3.10: The China/Japan ratio in educational attainment by level of education 94

Figure 3.11: Years of schooling by birth cohort and gender....................................96

Figure 3.12 : Years of schooling by birth cohort and urban-rural divide ..................97

Figure 3.13: AYS stemming from enrolment data vs CHIP ..................................98

Figure 4.1: Primary Schools by Management ........................................................ 107

Figure 4.2: The structure of gentry \& levels of the Civil Service Exam ..................127

Figure 4.3: Distribution of Shengyuan quota, for both early and late Qing............. 138

Figure 4.4: change of quota vs. economic factors.................................................. 154

\section{Maps:}

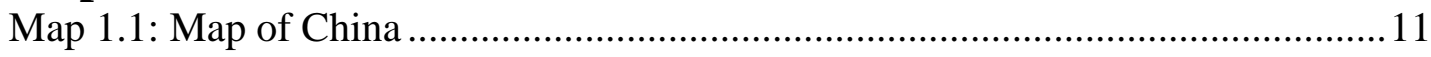

Map 1.2: Regional political and military tensions (1911-1928) .............................. 18

Map 4.1: The 'open and rich' regions vs. the rest of China..................................117

Map 4.2: The Geographical Data Covered ........................................................... 134

Map 4.3: Soil suitability for major crops ….................................................... 143 


\section{Introduction}

On a freezing afternoon in late January, 1913, my great grandfather assembled the Gao family in the grand hall of his courtyard home. He was about to tell the whole family that the Sishu ${ }^{1}$, which he had run for decades in Qi County of Shanxi province and which people travelled far to attend, had to be closed. The future was as unimaginable as the past. He had reasons to be worried: the world he used to live in, understand and be good at had been turned up-side down. The Emperor was gone; the queue hanging behind men's backs for more than 200 years had been cut off, ${ }^{2}$ and he was deluged with new terms, such as 'democracy', 'republic' and 'science'. The same day, my great grandfather, the last gentry member of the Gao family, who had obtained the title of Gongsheng ${ }^{3}$ and had long been one of the most respected persons in the county, walked for about an hour along the dusty road to the county seat. A little reluctant and probably terrified, he knew that a new era was coming, and he refused to not be part of it. From then on, he became a teacher and one member of the school board of the first modern secondary school in this remote county.

This thesis is indeed not about one person or one family's vicissitudes. Since the last decades of the crisis-ridden late Qing era, China as a whole was under unprecedentedly far-reaching and comprehensive transformations. The old order was abandoned, and great emphasis was placed on intellectual, economic and social Westernization; the advent of a modern educational system consisted in great part of this. Traditional Confucian teaching was practised in China for more than a thousand years. It was abruptly discontinued in 1905, and was replaced by a modern national

\footnotetext{
${ }^{1}$ Sishu is the Chinese traditional educational institute, where people attend to receive basic education and prepare for the civil service examination. We will elaborate on the function of Sishu in later chapters.

2 The queue was the compulsory hairstyle for all males in the Qing era (1644- 1912). In the early 1910s, after the fall of the Qing dynasty, the Chinese no longer had to wear it, and most of them abandoned it after the last Emperor, Xuantong (1909-1912), cut his queue in 1922.

${ }^{3}$ The so-called Gongsheng (贡生) especially designates scholars who had passed the first level of the civil service examination, and were then recommended for a place in the Imperial Academy; they were eligible to hold a government post and become an official bureaucrat. They constituted members of the higher tier of degree holders (or gentry class) under the traditional education system. Regarding the details of the structure of degree holders (gentry) in traditional education, please refer to Figure 4.2 in Chapter 4.
} 
education system that approximated to a Western education model. Such an educational movement completely altered the why, how and what of education that Chinese people received.

Systematic study on the Chinese experience with modern education remains wanting. How quickly and widely did the new education system spread? Did the birth of the new education model increase the level of human capital level in the country? Was solely the state promoted, contributed and responsible for the progress of modern schooling through this period? Among different vested interest groups, who actually implemented the reforms and carried them out? Who benefited from the educational reform and who lost out? How did the increasing demand for modern education generated by economic development fit into this story? Unfortunately, the existing literature provides too few answers to too many questions, and this thesis therefore aims to study the origin of the modern education system in China, measure its progress and assess its underlying driving forces.

This thesis is largely motivated by two puzzling observations. First, a new education model, which emphasised government intervention, usually results from the aspiration of a strong modern state. How did the withering Qing Court, which was struggling to deal with internal turmoil and foreign penetration, initiate the birth of this new education system days before its collapse? In the same vein, why was this educational reform carried out consecutively by successive regimes in a period of political chaos? Second, the conventional wisdom points to one simple fact: that a public schooling system requires an economically strong state to implement it. We should expect to observe that wealthy regions tended to have better education, while poor areas would be more likely to provide less. However, what strikes us at first glance is that the prominent regional frontrunners in terms of economic prosperity, such as the Lower Yangtze Delta, did not notably outperform in schooling; implying that economic factors may not be the main predicator when it comes to modern educational expansion. If this is so, what socioeconomic factors accounted for the rise of modern schooling in China? 
Before addressing these puzzles, the phrase 'modern education system' in this study requires clear definition. The purpose of the term 'modern education system' is to contrast with the traditional and indigenous system that provided classic education in Imperial China (221BC - AD1911). From historical accounts, the formation of a system of formal schooling at least partly funded and supervised by the state which provided universal education for all children of school age in Europe and North America from the early $19^{\text {th }}$ century onward marks the beginning of global modern education It is sometimes also referred to as a 'national education system' (Green, 1990, p. 297). ${ }^{4}$ Two major achievements emerged regarding this global education model. For one, schooling is at least partly provided, and funded by the state (Goldin, 2015; Goldin \& Katz, 2008; Green, 1990; Lindert, 2004a; Mitch, 2013; Remick, 2004). It is true that in the history of education, there are times when the private sector has delivered more than at present, but public schooling has apparently increased in relative importance as the private sector has shrunk. Additionally, another critical feature consists in the emphasis of the education system on secular, practical and academic areas of learning (Goldin \& Katz, 2008, pp. 149-152; Green, 1990). Thus, the phrase 'modern education system' in the following chapters can be understood as the Chinese version of the school systems developed in Europe, the US and Japan from the early $19^{\text {th }}$ century onwards. These education systems are distinct in many ways, but fundamentally they are similar with several core characteristics: they are universal, mandatory, ${ }^{5}$ secular and academic, providing what is widely considered to be an institutionalised model of national development around the globe. In a nutshell, the 'modern education system' in this study refers to an education system which possesses the above critical features.

To describe the journey towards the modern education system and uncover the determinants of its expansion, this thesis is laid out in four parts. Chapter One sets the historical, political and economic foundation for the advent of the modern education system in China. Then, Chapter Two provides a general roadmap for this modern education system, revealing its origins, structure, evolution and virtues. The

\footnotetext{
${ }^{4}$ There were numerous attempts at a blueprint for a modern education system from the late $17^{\text {th }}$ century and $18^{\text {th }}$ century pioneered by monarchs in Europe. Unfortunately, due to lack of resources, such attempts were not implemented effectively until the early $19^{\text {th }}$ century.

${ }^{5}$ The mandatory features of education apply only to basic education. The coverage of compulsory education usually starts in the primary years and goes on until the secondary stage. The timing of change is largely different across countries, but the pattern and trend remain similar.
} 
third chapter provides long-term estimates on how far education progressed through the 20th century based on a rich variety of indicators: literacy rates, enrolment ratios and, more importantly, the stock of human capital (average years of schooling). This exercise allows Chinese accomplishments in education to be put into international perspective. Furthermore, the fourth chapter, one of the core sections of this thesis, tackles one hotly debated question; 'what factors drove the rise of mass schooling (primary education)?' Given its political turmoil and economic backwardness, the expansion of modern primary schooling in China which was mainly driven by increasing public efforts seems puzzling. What contributed to the noteworthy diffusion off mass education in China? Based on a dataset that covers more than one thousand counties, we find that economic factors have little power to explain the variations in educational outcomes. In contrast, both the informal practice of governance imposed by the gentry (one important social group in Chinese history) and regional political stability are presented in all their critical importance. 


\section{Chapter 1 : Setting the scene: political and economic background of a modern education system}

The purpose of this research is to study the rise of modern education in China and its underlying driving forces. To be sure, these cannot be understood without context; for example, what was the political environment where the new education system was implemented? What kind of economic foundation generated the increasing demand, if any, for modern education? The first chapter provides a general answer to these essential questions, and sets the scene for subsequent analytical chapters. Not only will the history of modern Chinese education since the late $19^{\text {th }}$ century be told, but the chapter will also set out the economic and political foundations of educational reform.

At the dawn of the $20^{\text {th }}$ century, China experienced one startlingly sweeping educational movement: the traditional education model came to an abrupt end, and was replaced by a brand new system. In order to provide a clear roadmap for the journey of transforming a long-lasting traditional education system, this chapter will be organised as follows. First, the literature on why states intend to intervene and support education will be summarised. Then, the political and economic conditions in China at the time, which provide a historical context to the rise of modern education, are analysed separately.

\section{Starting Point: why does the state support schooling?}

The main focus of this chapter is to lay the foundation for later discussions; hence, we start our analysis with the origin of modern education systems and try to answer one basic question which has yet to be confronted: why does government become involved, invest in and support education? ${ }^{6}$

The principal reason why a government provides schooling is because increasingly, people consider education as an overall benefit to a society as a whole (Freire, 1976; West, 1965;

\footnotetext{
${ }^{6}$ Individuals tend to invest in education for many reasons; these have been thoroughly studied by labour economists. To summarise briefly, a person's final educational outcome is largely associated with household decisions, including household income and parental educational background, etc. However, this individual perspective on the reasons for investing in education is not the focus of the present research and will not be discussed here. This thesis is concerned more about public choices regarding education; specifically, why and how governments or communities come to a decision to expand schooling.
} 
Wiseman \& Peacock, 1962, pp. 29-39). As the broad range of positive external effects of education is proved by scholars, the intrinsic tension over whether governments should provide education or leave it to the private sector lies between the private demand for education and externalities brought about by the accumulation of human capital (Mitch, 2013).

An education system reflects a nation's values, customs, languages and collective priorities. The foremost among many purposes of education include: transmitting knowledge and cultivating common values between people and across generations. As education generates positive externalities of many types for a society, in the following section, various externalities of education will be discussed under one or other of the two chief purposes of education.

To begin with, regarding the principal function of education - the transmission of knowledge, the government intervenes and encourages education to create a literate, skilled and educated populace, which is widely believed to contribute positive effects to the economy, political institutions (in democratic countries in particular) and social utilities. The first obvious positive externality of higher human capital in the population is apparent from the economic perspective. The public provision of education, which prominently reduces the cost of education, allows knowledge to spread to more people to match the rich variety of needs of a prosperous economy (Lange, 2006; West, 1965, pp. 87-110). Politically speaking, as suggested by Lipset, education leads to more informed and engaged citizens. This is exceptionally important for societies which grant political participation to the population; because mass education stands as a basic and essential requirement to keep the election procedure functioning, to encourage the poor to be more politically active and to enhance the capacity of citizens to make good 'electoral decisions' (Castelló-Climent, 2008; Freire, 1976; Gallego, 2010; Lindert \& Go, 2010, pp. 40-49; West, 1965, pp. 40-49). ${ }^{7}$ Last, from a social point of view, education can generate for society a handful of further positive externalities; for instance, a lower crime rate and lower mortality (Goldin, 2015; Lange, 2006; West, 1965, pp. 70-86). In the scenario seen in China through the early $20^{\text {th }}$ century, the principal impetus

\footnotetext{
${ }^{7}$ Empirically, the correlation between democracy and education has long proved to be positive, but to establish the causality requires more solid empirical studies. There is no solid evidence to prove that democratic societies tend to provide more education than non-democratic countries for the period before the early $20^{\text {th }}$ century. The pattern emerges only after the second half of the $20^{\text {th }}$ century (Lance, 2011).
} 
for the state to establish a new national educational system consisted more in its urgent ambition to become an economically strong nation, and less in the pursuit of social and political objectives.

Furthermore, a government's involvement in education is intended not only to encourage quantity in schooling; in many cases, it is an action to ensure that the 'right' quality of knowledge and skills will be transferred to the population. Different types of educational content may lead to very different economic developments, political institutions and state capacity in any given country. Therefore, the state has a large stake in guiding the design of the content of schooling (Jones, 2008; Yuchtman \& Cantoni, 2013). For instance, in a small country with limited natural resources, Singapore's government regarded the economy as driven by high technology, and as underpinning the right national development strategy; consequently, education in science and technology has long been vigorously promoted and encouraged in Singapore as the 'right' kind of knowledge. In short, only the government could take the initiative in shaping the incentives to acquire different forms of human capital, because the cost of changing incentives and moving towards a new type of education is simply too great for any individual to bear. Going back to China specifically, the introduction of Western subjects, or what was called 'useful knowledge' in the modern education system in place of the long-standing classic Confucian teaching at the dawn of the $20^{\text {th }}$ century clearly demonstrates the single-minded ambition of the Qing Court to deliver the new type of education to its population as a national survival strategy.

In addition, education not only transmits knowledge; another of its primary functions is to cultivate a set of common values to shape people's beliefs, preferences and ideology (West, 1965, pp. 70-86). Therefore, a state's compelling interests in education also lie in its urge to forge a indoctrinatory, political, or religious uniformity as a modern state and to cement ideological hegemony (Green, 1990, p. 298; Lott, 1990b; Melton, 1988; Ramirez, O, \& Boli, 1987). ${ }^{8}$ Education has a long history of engaging in the process of state-building, or in some particular cases, of specifically enhancing a regional, tribal, ethnic or religious identity and set of values. From historical accounts, the formation of a national education system began across Europe in the $19^{\text {th }}$ century, initiated by thriving 'national sentiment' (F. O. Ramirez \&

\footnotetext{
${ }^{8}$ In Europe, religious and philosophical groups had long been predominant in education. It is clear that government intervention in education starting from the $19^{\text {th }}$ century was an endeavour to establish a national education, which could monopolise not only educational resources, but also rising nationalism.
} 
Boli, 1987). Later, the mass education movement in American between the $19^{\text {th }}$ and $20^{\text {th }}$ centuries is also argued to have been largely a political outcome of the surge of independence and democracy (Bowles \& Gintis, 1976; Dewey, 1916). Similarly, the Communist and Socialist educational 'brainwashing' in the Soviet Union, Eastern Bloc and later China between the 1950s and 1980s, is said to have pursued one single goal - forging the communist indoctrination of the populace (John R. Lott, 1999). Accordingly, the birth of an education system was securely incorporated within the compacted process of state-building in the global context, and three historical factors have been proved to be largely relevant: external military threats, internal revolution and programmes seeking to escape economic underdevelopment (Green, 1990). ${ }^{9}$ At the turn of the $20^{\text {th }}$ century, China possessed all three of the above factors, which was why the state-led educational reform was rigorously pursued at the time,. Through it, both Western subjects and certain new doctrines, such as the "Three Principles of the People", namely nationalism, democracy, and livelihood, were generally emphasised and promoted. ${ }^{10}$

However, this does not mean that the education system is solely a product of government that can only be imposed from top-down. On the contrary, significant educational progress in human history has often been initiated by increasing demands from civil societies. ${ }^{11}$ However, this scenario is more likely to be witnessed in democratic nations or societies with good political institutions through which demands from the masses can be heard, and their needs considered, by the government. To tell the truth, the rise of modern education in China was not like this.

In conclusion, historical and global experiences suggest that the formation of a modern education system is deeply integrated with both the political environment and economic development; and the fundamental impetus for the government to establish a national education system comes from the economic and political externalities generated by education. Therefore, in the following sections, these two aspects of the Chinese context will be further explored.

\footnotetext{
${ }^{9}$ This study has no intention of discussing the difference between state-building and nation-building.

${ }^{10}$ The 'Three Principles of the People' is a political philosophy developed by the founder of the Republic of China - Sun Yat-Sen. These three principles are often translated and summarised as nationalism, democracy, and economic security (民主，民生，民权)(Lary, 2007, p. 21).

${ }^{11}$ For instance, compulsory education in the USA came later given the fact that many states had already spontaneously provided compulsory secondary schooling for their citizens (Goldin \& Katz, 2011).
} 


\section{Economic and political foundation of educational development in the early $20^{\text {th }}$ century}

The advent of the modern education system in China occurred during the final days of the 19th century. Summarising this historical course is beyond the possible; as Fairbank remarks: 'The history of modern China ${ }^{12}$ cannot be characterised in a few words, however well chosen' (Rankin, Fairbank, \& Feuerwerker, 1986). Too many events occurred; too many hopes soared; too many wars were fought; too many reforms were explored; and the outcome can only be described as mixed. Seeking to understand the establishment of the modern education system, which took place through such a transformative, dynamic and turbulent time, this section focuses on its origin, and reveals the economic and political foundation on which was built the educational transformation; this altered the trajectory of Chinese development in the remaining decades of the 20th century.

\subsection{Historical Background: The awakening Empire}

China's modern history began with one great and dramatic event, namely the confrontation between the persistent and agrarian-bureaucratic Chinese civilisation, and the expanding, if not aggressive, Western powers (Fairbank, 1978). From the middle of the $19^{\text {th }}$ century, facing both the urge for openness from European Imperialism and the internal appeal for modernisation, the Qing throne (AD 1644 - 1911) adopted a defensive posture, leading to a series of enormous humiliations suffered on the battlefield, with consequent loss of sovereignty.

The Qing state did not await its downfall without exploring resolutions, and an this ancient country did to an extent awaken. The first initiative by the Qing Court was referred to as the Self-strengthening Movement. ${ }^{13}$ In order to encourage the adoption of Western technology, arsenals, shipyards and military schools were built, translators were trained in universities, and young talent were sent abroad under the rubric of 'Chinese learning is for the sake of the

\footnotetext{
12 This outbreak of the First Opium War in 1839 is considered by many historians the beginning of modern Chinese history, suggesting its profound influence on Chinese society.

${ }^{13}$ The Self-Strengthening Movement (1861-1895) represented a period of institutional reforms initiated during the late Qing dynasty following a series of military defeats. Some high-ranking Imperial officials believed that in order to strengthen Chinese military might, it was necessary to adopt Western military technology and armaments. Throughout this period, a number of military arsenals and shipbuilding dockyards were constructed to strengthen the Chinese navy, and the first group of Chinese students was sent to the United States sponsored by the Qing State. The Self-strengthening Movement was a highly Western-influenced reform, but due to the conflict between conservatives and pragmatists, the reform did not extend much further than the scope of military modernisation.
} 
essence, Western learning is for the sake of utility' (中学为体, 西学为用) (Lary, 2007, pp. 15-16). Unfortunately, such efforts were too little and too late. The last straw on the Qing dynasty's back was the bitter blow of the battles in the first Sino-Japanese War, ${ }^{14}$ where a disastrous defeat clearly revealed the weakness of the Qing state, and the perception of China was sweepingly altered, leading to the extensive diffusion of anti-Qing sentiment within society. In the immediate aftermath, the Empress Dowager Cixi finally agreed to full-scale political reforms in 1901 as an inevitable development, ${ }^{15}$ which included experiments in constitutional practice at the national level, as well as representative governments at the local level (Chien, 1950, pp. 52-55; Ichiko, 1980). Such drastic political and bureaucratic reforms required brand new talents and ideologies to support them, which paved the way for the educational movement of 1905. Ironically, the late Qing reform, which was originally designed to save this ancient empire, partly contributed to its downfall in 1911. Fortunately, through the following chaotic and turbulent ages, the great aspiration of forming a new and modern China was shared by successive regimes. Therefore, reforms aimed at modernising China, including an expanded modern education system, continued through the years of the Republic.

Table 1.1: Timeline of Chinese history \& educational progress

\begin{tabular}{|c|c|}
\hline Timeline & Major consequence \\
\hline \multicolumn{2}{|l|}{ Late Qing ( 1840 -1911) } \\
\hline The first Opium war (1840) & Forced opening-up of China: Western influence flourished \\
\hline Self-strengthening Movement(1861-1895) & A wave of adoption of Western military technology \\
\hline The first Sino-Japanese war (1895) & The weakness of the Qing was revealed $\rightarrow$ anti-Qing sentiment \\
\hline Late-Qing Reform (1901-1911) & Full-scale reforms $\rightarrow$ the abolition of the civil service exam \\
\hline \multicolumn{2}{|l|}{ Republic of China (1912 - 1949) } \\
\hline Early Republican (1912-1916) & Reform and modernisation of the education system continued \\
\hline Warlord Era (1916-1928) & Central power was largely undermined by 'regional regimes' \\
\hline Nanjing Decade (1928-1937) & Attempts to nationalize everything including education \\
\hline
\end{tabular}

\footnotetext{
${ }^{14}$ In 1895, Japan triumphed in the first Sino-Japanese war, and China signed the Treaty of Shimonoseki. Although Qing China had been defeated by European powers in the 19th century, defeat at the hands of an Asian power and a former political and cultural subordinate was a bitter blow.

15 The throne issued an imperial edict in 1901 calling for reform proposals, and initiated the era of the dynasty's 'New Policy', also known as the 'Late Qing Reform'.
} 


\subsection{Understanding the political domain}

As discussed, the formation of a new national education system was inherently political and therefore required extensive cooperation and coordination among various tiers of government. In order to understand how the spread of modern schooling can be executed, this section looks at the political environment where the new education system would function. To do so, we introduce the formal political and administrative institutions - the nominal government structure throughout this historical course. Equally important, the underlying tensions in the landscape of politics are further uncovered, which probably played an even more definitive role in the way in which China was ruled in practice.

\section{Map 1.1: Map of China}

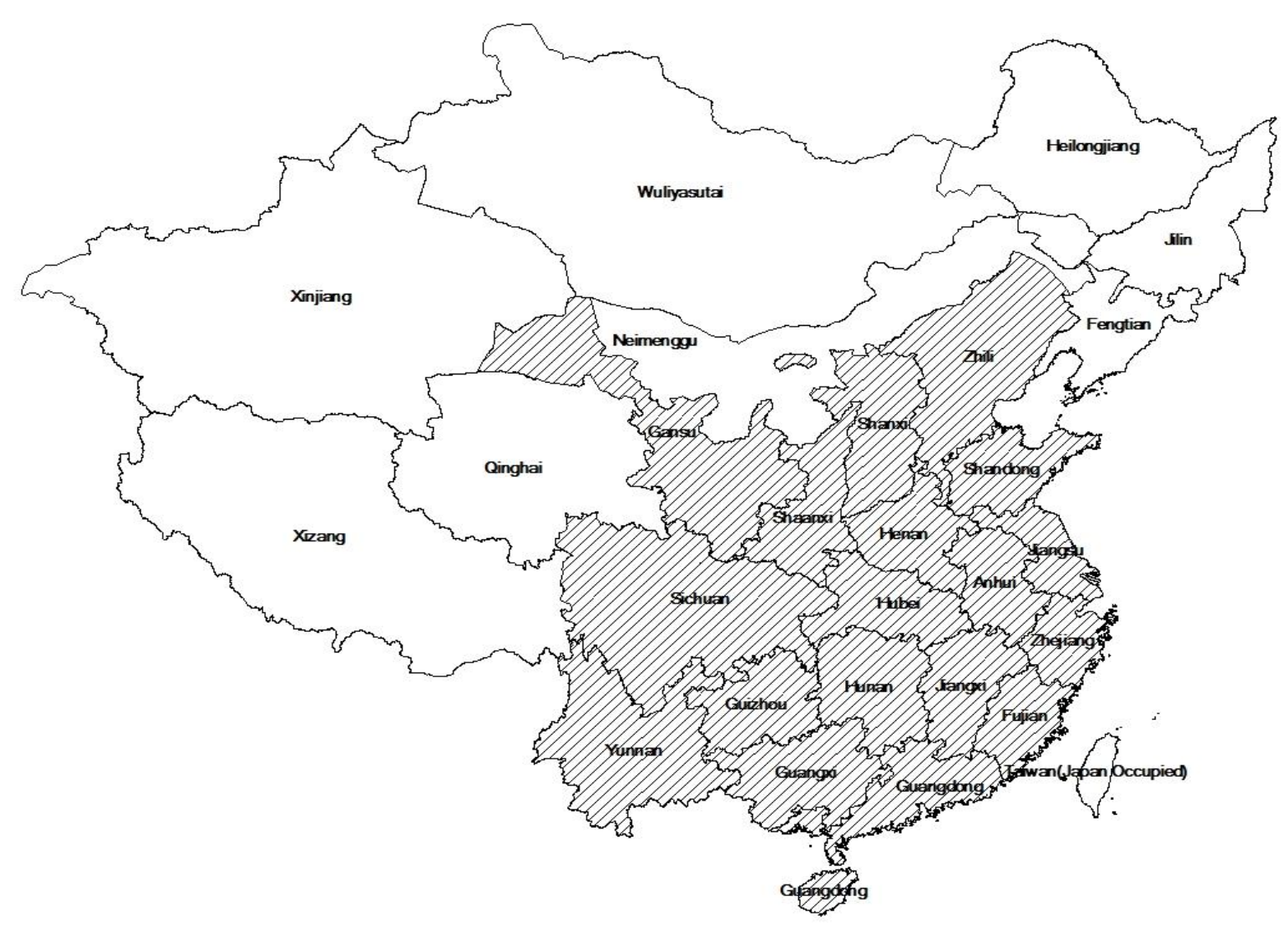

*Note: The shaded regions refer to the area of China Proper ${ }^{16}$

\footnotetext{
${ }^{16}$ China proper is a term usually used to express a distinction between the core and frontier regions of China. More explicitly defined, China proper covers 18 provinces as marked on this map, and this study focuses largely on China proper, given that it accommodated more than $80 \%$ of the population (measured by late Qing population data). The provinces are Anhui, Fujian, Gansu, Henan, Hubei, Hunan, Jiangsu, Jiangxi, Guangdong, Guangxi, Guizhou, Shannxi, Shanxi, Shandong, Sichuan, Yunnan, Zhejiang, and Zhili. The scope of this study is mainly limited to China proper.
} 


\subsubsection{Formal government structure}

How central and local governments are structured within a political framework is vital for our understanding of the way that responsibility for promoting modern education was allocated to various tiers of government. Hence, this section sets out the general government structure of China, and briefly outlines the corresponding responsibilities.

Table 1.2: The formal government structure of China (both late Qing and Republican)

\begin{tabular}{|l|c|c|c|c|c|c|}
\hline \multirow{2}{*}{ Unit } & \multirow{2}{*}{$\begin{array}{c}\text { chief } \\
\text { administrators }\end{array}$} & \multicolumn{2}{|c|}{ Number } & \multirow{2}{*}{ Size $\left(\mathrm{km}^{2}\right)$} & \multicolumn{2}{|c|}{ Average Population ${ }^{17}$} \\
\cline { 3 - 6 } & & Late Qing $^{18}$ & Republic $^{19}$ & & Late Qing & Republic \\
\hline Province & governor & 22 & 28 & $1.40 \mathrm{E}+07$ & 18990338 & 23384838 \\
\hline Prefecture & prefect & 302 & 319 & 14279 & 1308720 & 1422432 \\
\hline County & Magistrate & 1303 & $2122^{20}$ & 2297 & 251733 & 260598 \\
\hline Village & Village head & 8658 & - & - & - & - \\
\hline
\end{tabular}

*Sources:

(i). The number of administrative units: for the late Qing period: (Qu, 2003, p. 43); for the Republican period: (Chien, 1950, p. 418); specifically for China proper: (Bol \& Ge, 2007)

(ii). Territory size: (Bol \& Ge, 2007)

(iii). Population: (Hou, 2001; Stauffer, 1922)

Overall, both the central state and local government in Chinese history strove to restrain the scope of their responsibility in most of the public sector and presented very limited functions in terms of governance. ${ }^{21}$ Owing to the limited size of the bureaucracy, ${ }^{22}$ a large population and the sheer scale of the territory, one essential challenge of the Chinese state lay in the extraordinary high agency cost of its administration (Brandt, Ma, \& Rawski, 2014; K. G. Deng, 2011, pp. 25-36; Remick, 2004, pp. 29-39; Sng, 2014). Such an institutional set-up

\footnotetext{
${ }^{17}$ Due to lack of data on the population of peripheral provinces, the population numbers only cover China proper.

${ }^{18}$ The number presented in Table 1.2 for the late Qing period draws data from records under the Guangxu Emperor (1871 - 1908).

${ }^{19}$ The number presented in Table 1.2 for the Republican era derives from the Ministry of the Interior under the Nationalist government in 1947.

${ }^{20}$ The number 2122 includes 100 municipalities sharing the same administrative rank as the counties.

${ }^{21}$ From the $8^{\text {th }}$ century, bureaucratic recruitment became standardized and impersonal. Officials were selected from a small amount of successful candidate of civil service examination. For these degree holders (gentry), their prestigious status as social elites and the chances to be chosen as bureaucrats were all tightly connected to the Imperial regime(B. A. Elman, 2013). The structure and social functions of degree holders will be further explained in Chapter Four.

22 The size of bureaucracy in Imperial China was extremely small. Under the rule of Qing, there were fewer than 30000 bureaucrats on its payroll, and 2546 of which filled the key positions in central government. It meant that about 24000 officials need to cover 11 minion $\mathrm{km}^{2}$ territories, about 2000 counties and more than 400 million population (K. G. Deng, 2011, p. 25)
} 
caused the Imperial Chinese state to voluntarily withdraw from many of its public duties, resulting in low formal taxation and also limited state activities (Brandt et al., 2014; K. G. Deng, 2011, p. 36).

The structure of government had considerable continuity in terms of administrative organizations and functions. As presented in Table 1.2, the Qing Empire inherited from its predecessors a four-tier government structure comprising provinces (sheng 省), circuits (dao 道), prefectures ( $f u$ 府), and counties (xian 县), i.e. four tiers beneath that of central government. Even though some revisions were proposed and undertaken after 1911, the core of the government structure stayed intact. In theory, all levels of local government acted only as agents of the central administration within a strict hierarchical structure, where the chief administrators formed a political ladder, and were responsible to the grade immediately above and for the grade immediately below (S. Cheng, 1919, pp. 136-138; Chien, 1950, pp. 43-44).

The province (sheng 省) was the largest administrative unit, and was administered by a governor (xunfu 巡撫), who possessed the main administrative power within his territory; ${ }^{23}$ while as a power balance, the provincial governor was subordinate to a viceroy (zongdu 总), who was especially entrusted with military tasks throughout one of the nine macro-regions (Qu, 2003, p. 13) ${ }^{24}$ However, in many cases through the Republican era, the provincial governors were also the viceroys who controlled all provincial affairs, both civil and military, making them extraordinarily powerful regional leaders. ${ }^{25}$ Politically, the provincial government was directly subject to the central government, and the appointment and evaluation of provincial governors was strictly controlled by central government (S. Cheng, 1919, pp. 136-137). Nonetheless, economically speaking, given that even the smallest province in China, Zhejiang, was larger than Portugal; with limited access to modern

\footnotetext{
${ }^{23}$ For the governor of a province, his power varied significantly, depending upon circumstances.

${ }^{24}$ Under the rule of Qing, there were nine viceroys in total: the Viceroy of Zhili, Viceroy of Liangjiang, Viceroy of Min-Zhe, Viceroy of Huguang, Viceroy of Shaan-Gan, Viceroy of Liangguang, Viceroy of Yun-Gui, Viceroy of Sichuan, and Viceroy of Northeast provinces. Exceptionally,Shanxi, Shandong and Henan were not included in any of the nine regions; therefore, they were not governed by any regional viceroys. Historians usually rank the viceroyalty of Zhili as the most powerful post; Yuan Shikai, the first president of the Republic of China, was the last Viceroy of Zhili in the late Qing period.

${ }^{25}$ In the early days of the Republic, the political leadership in most provinces was drawn from the army, where 12 out of 17 provinces in China proper had military men as governors in the middle of summer 1912 (Young, 1983).
} 
transport and communications, most provinces were self-sustaining and independent (Chi, 1936, p. 4).

Regarding the two intermediate layers of local government - the circuit (dao 道) and the prefecture ( $f u$ 府), they were not administrative units and held very restricted functions. ${ }^{26}$ The circuit was administered by circuit intendants (daotai 道臺), who were specially responsible for transportation issues, for instance, waterways and food transportation (C. S. Li, 1922, pp. 33-34); while prefectures, which were governed by prefects (zhifu 知府), functioned largely as a channel of communication between province and county (C. S. Li, 1922, p. 34). The average size of a prefecture was about that of Belgium; hence, daily administration was too challenging to carry out effectively; consequently, it was later divided into counties.

The single most vital unit of Chinese local government was the county (Xian 县). The county government was responsible for an exceedingly rich variety of duties: legislative, judicial, executive and tax-collecting functions were all in the hands of its magistrate (zhixian 知县) (S.-G. Cheng, 1919., pp. 135-136; C. S. Li, 1922, p. 34; Qu, 2003, pp. 29-34; Zhong, 2003, pp. 18-26). Interestingly, except for a few very basic and vague regulations on its standard responsibilities, there were no further protocols to specify the activities that a county magistrate should undertake; therefore the county magistrate could go as far in these local affairs as his interests led him (Chien, 1950, pp. 43-45; Qu, 2003, pp. 29-34). Such a high level of flexibility in the scope of the county government's functions was propitious for selfgovernment at the level of the local community.

In the end, since direct state administration stopped at county level, the county in theory was the lowest state organ under both the Qing Empire and the later Republican rule (K. G. Deng, 2011 , p. 26). However, with an average county population of 250,000 , the county unit was always further divided into townships and villages. ${ }^{27}$ Even though these numberless grass-

\footnotetext{
${ }^{26}$ To streamline the levels of Chinese administration, the circuit and prefecture were abolished as distinctive units of local government in a row after the founding of the Republic of China in 1911 (S. Cheng, 1919, p. 138). This change resulted in the corresponding provincial governor's direct supervision of the county magistrates. However, it was soon realised that it was not feasible for the provincial government to directly manage dozens of counties; as a result, the prefectural layer was restored between province and county (S.-G. Cheng, 1919., pp. 135-146).

${ }^{27}$ At grass-roots level, the two systems coexisted. Besides the natural division of county into villages, for the purpose of control in the rural areas, the Qing Court instituted a police control system - Bao Jia and Li Jia. However, this sub-administrative system was superimposed upon, without replacing, the natural division
} 
roots governing organs did not obtain legitimate status as administrative sub-divisions, their daily governance was carried on by various state agents via non-bureaucratic means (Hsiao, 1960 , p. 5). ${ }^{28}$ In the same vein, village chiefs were not government officials either; instead, they were respectable native gentry, ${ }^{29}$ who were selected by the residents of the locality $(\mathrm{C}$. S. Li, 1922, p. 37; Qu, 2003, p. 41) ${ }^{30}$ In a nutshell, direct state control never penetrated below the county level; on the contrary, the management of local communities rested upon informal institutions, including guild, gentry, clan and lineage (S. Cheng, 1919, pp. 8-12; Duara, 1988; Schoppa, 1982). ${ }^{31}$ As a bridge between state and populace, the grass-roots governing bodies served two major duties. Village self-governance issues were their foremost responsibility, including the provision of public goods, mediating disputes and maintaining public order. At the same time, sub-county governing bodies were made subject to the control of the county magistrate; consequently they were also subject to the obligation to carry out state policies.

In summary, the political-administrative environment in China was formulated in a four-layer structure: the hierarchical division of central government, provincial, county, and the selfgoverning local community. In the following sections, the term 'local government' refers to both county and sub-county governing bodies.

\subsubsection{Underlying tensions in the political landscape}

Aside from the key political institutions and formal political-administrative structure, there were several critical themes in the realm of polity that probably played a more influential role in the ruling of China from the late $19^{\text {th }}$ century to the early decades of the $20^{\text {th }}$ century. Traditionally, state power under Imperial China was largely monopolised by the emperor, the

mentioned previously. This police control system is beyond the scope of this study, and is not included in the following analysis.

${ }^{28}$ The administrative township and village (Xiang 乡) had its origins in earl imperial time, By the Qing, it developed from a formal administrative unit to extra-bureaucratic status(Hsiao, 1960, p. 12)..

${ }^{29}$ The term 'gentry' (士绅 or 缙绅) has no complete equivalent in English. It possesses a distinct meaning unlike that in a European context. The gentry in Europe are usually associated with substantial land-holding and the aristocracy, both of which are inheritable. In China, the scope of the term is vaguer. It refers to people who have obtained high prestige via success in the imperial examination system, and are therefore office-holders, but this role cannot be inherited. The role of gentry in modern education development in China will be analysed in greater depth in Chapter 4.

30 The first attempt to extend political administration beyond the county level was in 1928, when the Nationalist government tried to establish official township government. (Chauncey, 1992, p. 42)

${ }^{31}$ After entering the Republican period, the government made some attempts to transform the power of the local elites into the official sphere. All types of social institution at grass-roots level, including chambers of commerce, education associations, agricultural associations, and militia organisations, were established. However, the local elites still dominated these institutions and in practice ruled rural China. 
literati-bureaucrats and the local gentry (Yamada, 1987b, p. 187). After the 1840s, the old equilibrium of power structures was destroyed, leading to many new developments and changing order in the political landscape. The foremost changes were in three areas, namely: (i) a decline in central control; (ii).fierce tension, if not conflict, among provincial regimes; and (iii).a power vacuum at the local level.

\section{The withering Central state and regional devolution}

At the outset, the single most important change in politics after the late $19^{\text {th }}$ century was that central control was evidently undermined by provincial powers, most of which carried strong elements of military government.

The Taiping Rebellion (1850-1864), which was crushed by provincial armies and not the Imperial Army, not only severely diminished the capacity of the Qing court, but more importantly, gave the power to train personal armies paid from provincial revenues to the increasingly powerful regional forces (S. Cheng, 1919, pp. 121-135; H. Chi, 1976, pp. 10-33; K. G. Deng, 2011, p. 70). ${ }^{32}$ In the same vein, the 1911 revolution was also led by provincial governments under the control of military viceroys. The historical legacy of these events paved the way in the next few decades for a weak central government to oppose powerful provincial powers under the new Republican regime (H. Chi, 1976, pp. 10-35; Chien, 1950, pp. 178-181; Mccord, 1993). The weakness of the central state persisted even after Chiang Kai-Shek reconciled the regional warlords and re-unified China in $1927 ;^{33}$ the new central government seated in Nanjing still struggled to keep its allies under its control (Eastman, Fairbank, \& Feuerwerker, 1986; Yamada, 1987a). ${ }^{34}$

\footnotetext{
${ }^{32}$ The irreplaceable contribution to suppressing the Taiping Rebellion was mad by a provincial army, the Xiang Army (its soldiers were all from Hunan province), led by a provincial leader, Guofan Zeng. The Army was financed through local revenues and support from local gentry, it therefore was firmly based on personal and regional loyalties (S. Cheng, 1919, p. 123). Another important provincial military force was the Huai Army (named after the Huai River and mainly based in Anhui province), led by Hongzhang Li; it later became the Beiyang Army. This devolution of centralized military control contributed to the eventual downfall of the Qing and the emergence of the 'warlord era' in China.

${ }^{33}$ From 1926 to 1928, the Kuomingtong (KMT) launched a massive military campaign, led by Chiang Kai-shek to unify China under its own control. The KMT successfully reconciled a number of regional warlords under its control, and therefore started to form an effective central government based in Nanjing.

${ }^{34}$ The new state tried many times to undermine the powers of previous regional regimes, but with limited success. Such attempts were fraught with difficulty, because the provincial warlords had not been defeated in battle but rather had been co-opted into the Northern Expedition movement. Here, the Nanjing Government had to tolerate a certain degree of independence among the provincial militarists who had voluntarily committed themselves to unification.
} 
The decline of central control can be observed in many military, fiscal and personnel areas. Taking tax revenue as an example, provincial governments appropriated most of the revenue without remitting any to the central budget; especially intent on doing so when money was needed for provincial military expenses (C. S. Li, 1922, pp. 83-84). ${ }^{35} \mathrm{In}$ fact, from the late Qing to the early Republican period, the few guaranteed tax revenues for the central treasury were the Maritime Customs tax and the Salt Tax; ironically, they were exempt only because they were collected by international organisations (Remick, 2004, pp. 37-39; Sheridan, 1977, p. 199). ${ }^{36}$

In a nutshell, civilian elites normally acquiesced to military government as a wartime necessity (Lary, 2007, pp. 39-40; Mccord, 1993, pp. 81-118). ${ }^{37}$ The seizure of power from the central state by military provincial forces occurred during the final stages of the Qing dynasty; it led to a weakening of central government, and the withering of central control, as a result of more powerful provincial 'regimes', in a self-intensifying vicious circle.

\section{Political and military tensions among regional powers}

As eloquently portrayed in many historical narratives, the decline of central control plus the rise of provincial military powers naturally created between the various regional military cliques a state of political and military tension, which led to mushrooming regional conflicts. By some calculations, in a period of merely 16 years (1912-1928), often referred to as the warlord era, over 140 militarists fought more than 1,300 provincial and inter-provincial wars (Billingsley, 1988, p. 24; J. Chen, 1968). ${ }^{38}$ In the same vein, it was wildly belived that at least 1.4 millions solders or armed men serving in military unites(Lary, 2007, pp. 61-62). The exact figure depends on the definition of an 'independent warlord'; however, these estimates provide a general picture of the fierce tensions between the provincial powers.

\footnotetext{
${ }^{35}$ In the late Qing, around $20 \%-30 \%$ of the total tax revenue collected at provincial level would be sent to the Imperial Treasury in the capital, known as the 'capital revenue', while the rest remained in the provinces for local use(Shi, 2009, pp. 25-33). The situation became much worse after the Republican era: many provinces refused to remit the tax revenue to the central authority.

36 The Maritime Customs House was managed and supervised under the control of the British, while the salt tax was collected by the Sino-Foreign Salt Inspectorate(Remick, 2004, pp. 37-39).

${ }^{37}$ Consequently, the top provincial executive changed from being a civil official, with a certain degree of supervisory authority over military forces, to a military official with even greater control over both military and civil administrations, usually documented as a warlord in Chinese history.

${ }^{38}$ One thing worth stressing is that even though so many regional wars were documented in history, it is widely believed that no large-scale fighting took place. In the same vein, according to demographic records, no widespread casualties occurred either.
} 
Map 1.2: Regional political and military tensions (1911-1928)

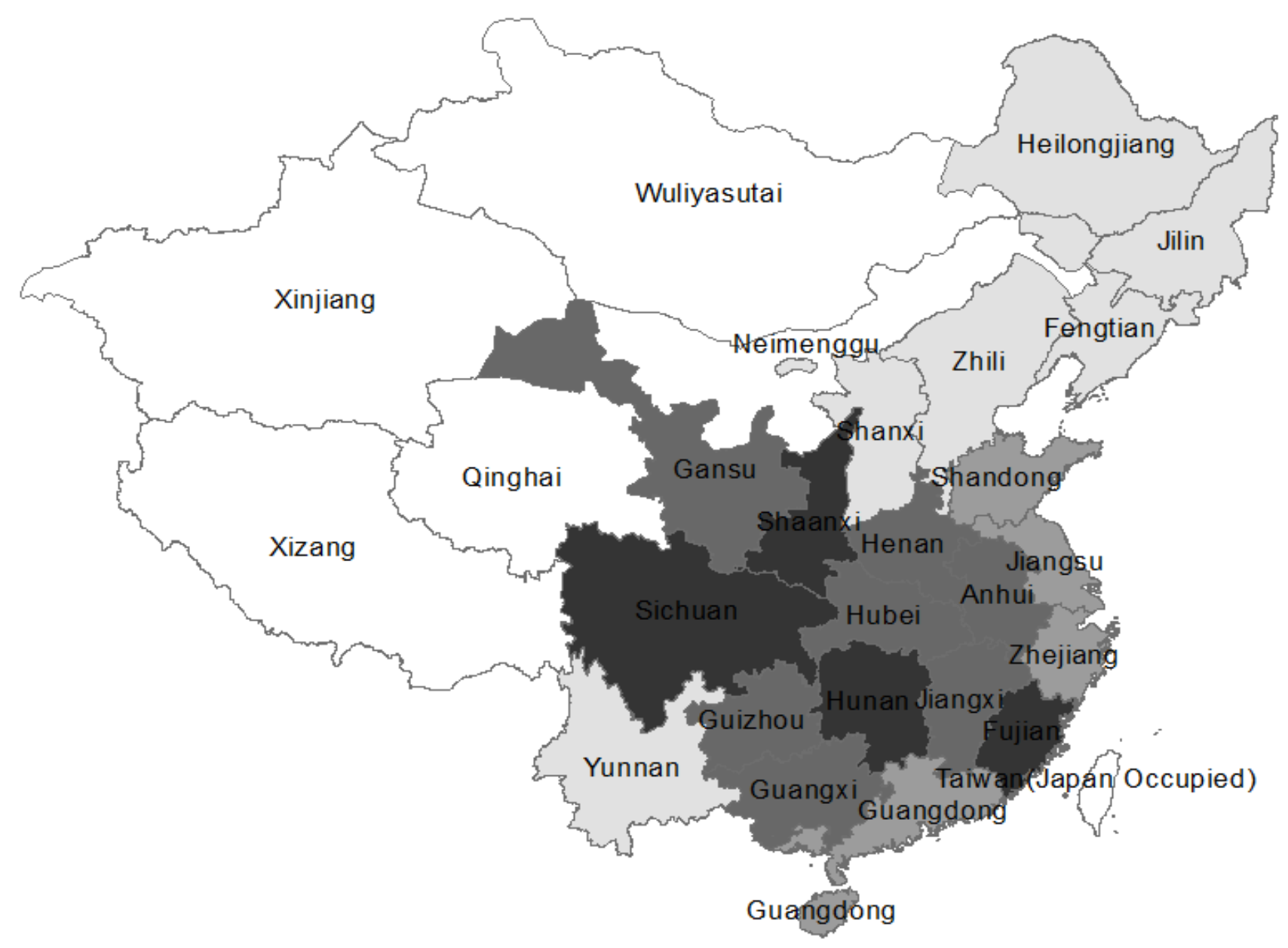

\begin{tabular}{|c|}
\hline Peripheral area \\
\hline Controlled by single military power \\
\hline Stable, expose to western power \\
\hline Certain degree of stability \\
\hline Warfare zone \\
\hline
\end{tabular}

Source: (Billingsley, 1988; H. Chi, 1976) 
One point that should be borne in mind when interpreting this historical course is that not all regions experienced chaos to the same extent. As displayed in Graph 1.2, some regions were ruled with an iron fist by either a single military strong man or a single military clique. In these cases, warlords could hold on to power for some considerable time, and these regions thus enjoyed a certain level of political stability. ${ }^{39}$ In contrast, other regions, owing to their strategically important location, became hotly contested areas for different warlords.

The cliques fighting against each other during this period were very complicated and changed over time. However, put simply, the country could be roughly divided into two major parts, North and South. As illustrated in Graph 1.2, the warfare zone was the buffer belt, which truly divided north from south, running from Shaanxi, Sichuan, West Hubei, north Hunan, Jiangxi to Fujian (J. Chen, 1968). ${ }^{40}$ This area suffered from endless battles between northern and southern forces, leading to frequent changes of military control, and the exploitation of tax revenues from the local economy. Besides strategic considerations, military conflicts were also centred on key economic areas, such as the Canton Delta, the Chengdu Plain in Sichuan, and the Lower Yangtze Delta (J. Chen, 1968). The infamous example of Sichuan province as the most chaotic and turbulent region through this period may be cited. ${ }^{41}$ In 1916 , the regular armies in Sichuan numbered around 8 divisions, rising to more than 24 between 1920 and 1929. Xin claims that 467 wars were fought (Xin, 1932). While this figure may not

\footnotetext{
${ }^{39}$ In fact, there were several autonomous provinces, legitimized the regional dominance of the major warlord groupings. Yuhsiang Feng controlled Gansu, Shanxi, and Henan. Xishan Yan controlled Shanxi. The so-called Guangxi clique dominated the councils at Hankou, Beijng and Canton, which were headed by Renzong Li and Chongxi Bai. Another branch political council arose under Xueliang Zhang in Manchuria (H.-S. Chi, 1976). Among these relatively stable regions, the most famous warlord was Xishan Yan who governed Shanxi province for almost 40 years. Similarly, in the cases of Yunnan, Zhili and Shandong, even though they all experienced changes of regional warlords, the controlling military factions in each province held tight to power, keeping the transitions significantly smooth.

${ }^{40}$ The establishment of the Beijing-Hankou Railway and Tianjin-Pukou line formed the A shape of the strategic region, which secured control of Beijing. In order to guarantee the defence of the A shape, the peripheral provinces, which formed a buffer belt, had to be controlled (J. Chen, 1968).

${ }^{41}$ The Sichuan warlords had rarely been involved in national political activities. Sichuan itself, as a large isolated and rich region, was the great prize for most Sichuan warlords. From 1919, Sichuan was cut up into several garrison areas (fangqu), each of which was ruled by one military division and enjoyed politically autonomy, independent of each other, of the provincial government, and of central government. In order to enrich and sustain their control of their own garrison areas, the local military regimes exploited the masses mercilessly. In some extreme cases; local governments even collected taxes 50 years in advance (Gunde, 1976). For instance, the surcharges could sometimes be 30 times higher than the land tax proper (Sun, 1935, pp. 213-217).
}

Table: sky-high surtax $v s$ bas tax in sample counties in Sichuan in 1920s

\begin{tabular}{|l|l|l|c|c|l|c|c|c|}
\hline County & $\begin{array}{l}\text { Ba } \\
\text { Xian }\end{array}$ & $\begin{array}{l}\text { Jiangbei } \\
\text { Xian }\end{array}$ & $\begin{array}{l}\text { Fuling } \\
\text { Xian }\end{array}$ & $\begin{array}{l}\text { Yunyang } \\
\text { Xian }\end{array}$ & $\begin{array}{l}\text { Wan } \\
\text { Xian }\end{array}$ & $\begin{array}{l}\text { Xingwen } \\
\text { Xian }\end{array}$ & $\begin{array}{l}\text { Yibin } \\
\text { Xian }\end{array}$ & $\begin{array}{l}\text { Pengshan } \\
\text { Xian }\end{array}$ \\
\hline Surtax / base tax $(\%)$ & 2943 & 2750 & 1875 & 743 & 3123 & 1250 & 1130 & 625 \\
\hline
\end{tabular}


be accurate, it is illustrative and allows the conclusion to be drawn that the political situation in Sichuan was anything but orderly. ${ }^{42}$

Facing such intense and competitive political and military tensions, most provincial governments strove to fully sustain their military rivalry with others, and sought to secure control over their territories; consequently, for the period under discussion the level of political stability across provinces differed widely.

\section{Power vacuum at the local level:}

The increasing strength of the provincial powers not only changed the balance between them and central government; it also altered the relationship between local government (county and sub-county) and higher levels.

On the one hand, with the decline of central power, local governments came more under the rule of the provincial 'regimes'. The undermining of central power over local affairs can be observed in many ways. For instance, in the control of personnel, under the Qing rule, provincial governors had only the right to appoint county magistrates from a list of candidates passed down by central government. In contrast, under the Republican regime, provincial governments often seized authority over personnel and assumed the power to appoint county magistrates themselves(Q. Wang, 2000; Y. Zhang, 1999). In the same vein, the traditional prohibition against officials holding posts in their home provinces was abandoned, though it had once been an essential method of preventing excessive patronage at the provincial level (Qu, 2003, p. 294). ${ }^{43}$ On the other hand, powerful provincial governments were busy fighting against each other, resulting in noticeably less management and supervision over local governments. To sum up, county governments faced an incapable central authority and an indifferent, if not predatory, provincial government.

In such a hostile and chaotic political environment, was local daily governance drastically affected? Fortunately, the answer is no. Many historians claim that the late Qing chaos, the 1911 revolution and the subsequent warlord era had remarkably less disruptive effect on local

\footnotetext{
${ }^{42}$ Because of the extremely turbulent situation in Sichuan province, we exclude Sichuan from our later empirical chapters.

${ }^{43}$ When going through more than 500 county gazetteers containing information on county magistrates, I found that in contrast with the long-lasting prohibition, a large proportion of magistrates had actually served in their home provinces during the Republican era.
} 
governments than people might have expected, because the daily operation of governance rested upon the grounded foundation of the local gentry, who had shaped the political fabric and social ruling in local communities for centuries (Keenan, 1994; Lary, 2007, pp. 50-51; Mccord, 1993, pp. 81-118; Sheridan, 1977).

Through the period under discussion, there were abundant new needs regarding public facilities and services, created by rising urbanisation, commercialisation and modernisation. Unfortunately, governments had little capacity to meet these demands. Therefore, collaboration between government and local elites, including merchants and educated gentry, was sanctioned by the state, with elite groups increasingly engaged in providing local public services, ${ }^{44}$ mostly in such economically developed regions as lower Yangzi. ${ }^{45}$ In other words, a total administrative collapse at local level was prevented via the assumption of power by local political figures (Chauncey, 1992; Mccord, 1993, pp. 81-118; McDonald, 1978; Remick, 2004; Sheridan, 1977) One may wonder why these grass-roots governing bodies, led by local elites, but not necessarily local government officials, would carry out and support a new educational model that was seemingly introduced from above. We raise this question here but answer it later more fully in Chapter 4.

In conclusion, the tension between political demands and educational development was so intense that it largely shaped the direction of educational reform and its evolution in this period. From the late Qing to the Republican period, the formal political structure remained more or less the same, and functioned as a four-level division: central, provincial, county and sub-county. However, the devolution of central power, conflicts between provincial regimes and the power vacuum at the local level profoundly impacted on the functioning of the political structure in the event.

\footnotetext{
${ }^{44}$ There were many aspects of these increasing activities of local elites, and here we mainly emphasise their role in the public domain and their desire and effort to expand education. One other crucial example of local elites' increasingly important role lay in the Lijin tax collection. The collection of this main source of tax revenue was quasi-official in practice, which strengthened even further the legitimacy of the local elite in local public affairs. ${ }^{45}$ The birth of the first municipal government in Shanghai can be considered an illustrative example of the way in which local power rose in response to the inability of the state. After the first Sino-Japanese war, Shanghai's local figures were organised and ran the new city council to carry out long-standing projects, such as widening the streets.
} 


\subsection{Understanding key features of the Chinese economy}

A more challenging task than understanding Chinese politics is to sketch the outline of economic development in China through the late Qing and the Republican eras, simply because we know so little about so many issues. This section, based on the sparse literature, aims to provide some definitive answers to the key questions about the Chinese economy as the background for the educational movement through this period.

How does the economic foundation influence the modern schooling system? Increasing household income generated by economic growth and changing jobs thanks to changes in economic structure are the two factors that are closely associated with the increasing demand for education. In the following section, the main focus is on two questions. First, was there obvious economic development through the period under discussion? Second, did job markets start to require different skills from the labour force?

\subsubsection{The onset of the economic growth?}

There are few valid estimates of a GDP series or other measures of the size of China's economy before 1949, apart from several benchmark years in the 1930s conducted by contemporary Chinese economists (T. C. Liu, 1946; Wu, 1947). Without benchmark years in late Qing or through the early Republican period, it is challenging to claim that there was economic growth during the first half of the $20^{\text {th }}$ century.

Nonetheless, some clues can be identified from other crude indicators. First, China's population grew from approximately 400 million in 1850 to 439 million in 1911 (Cao, 2000, pp. 703-704), and remained at 450 million around 1930 (T.-C. Liu \& Yeh, 1965, pp. 34-36). ${ }^{46}$ The increasing population density and sustained living standards suggest a certain level of economic development in this period (Brandt et al., 2014). In addition, Maddison's work shows a growth in GDP per capita from 1870 to 1913, and a drop in 1950, probably due to the effects of warfare in the 1940s (Maddison, 2006, pp. 241, 261). Furthermore, Rawski reports a promising growth rate in terms of the national industrial output index, with total output rising by two-fifths between the 1910s and 1930, reflecting an increase of 20-25 percent in output per capita (T. Rawski, 1989, pp. 329-343).

\footnotetext{
${ }^{46}$ Consensus on accurate Chinese population estimates has not yet been reached among historians and demographers. For instance, in the 1930s, the population figure in government records was 500 million; after making many adjustments, Wang reaches the same result.
} 
In short, without a series of GDP per capita through this period, scattered pieces of evidence suggest that there was a sustained expansion of the Chinese economy through the late Qing and Republican eras, albeit not as rapid as in other rising nations. In the late Republican period, the only standardized national income estimate, adjusted by PPP, shows that the Chinese per capita income still only accounted for 35 percent of the Japanese level in the 1930s (Fukao, Ma, \& Yuan, 2007).

\subsubsection{Were there changes in economic structure?}

The demand for education is related not only to the absolute growth figure, but also closely associated with changes in economic structure - from an agrarian to an industrial economy. Before the 1840s, China had been a closed and agrarian economy. How much did the economic developments alter the demand for skills in the labour market? Unfortunately, detailed data on the composition of employment and GDP by industry only became available in 1930s; hence no changing trends can be observed here to illustrate whether there was a changing demand for skills caused by any structural economic upgrade.

However, substantial historical details suggest that the onset of modern industrial expansion occurred from the late Qing to the first few decades of the $20^{\text {th }}$ century. Several programmes were launched by the late Qing court, modelled on Japan's Meiji Restoration. ${ }^{47}$ This wave of industrialisation was further accelerated by the tremendous growth in international trade. ${ }^{48}$ The nominal value of Chinese exports sextupled, while, in real terms, the figure tripled (Mitchener \& Yan, forthcoming), stimulated by the growth of the most important modern industry - manufacturing, including cotton textiles, cigarettes, matches, and rubber goods, proceeded steadily before 1937 (T. Rawski, 1989, pp. 65-119). In addition, a wide range of other modern industries flourished in several important economic sectors, namely, modern

\footnotetext{
${ }^{47}$ The first wave of industrialisation was largely stimulated by military demand, which can be traced back to the Tong-zhi Restoration (1862-1874) and the Self-strengthening Movement (1861-1895). Due to resistance from conservative Manchu elites, the scope of these programmes remained limited, but through the process, a batch of modern industrial enterprises was set up, including the pioneers in modern industry - government-supervised merchant companies. They were operated by merchants, but were controlled and directed by government officials; a few of them were extremely influential companies throughout China's business history, including the China Merchants' Steamship Navigation Company, Kaiping Coal Mines, the Imperial Telegraph Administration, the Hua-sheng Spinning and Weaving Mill and the Imperial Bank of China.

${ }^{48}$ Even though the Treaty of Nanking (1840) permitted foreigners to trade with China in five treaty ports, the great change came when the Treaty of Shimonoseki, signed with the Japanese after the first Sino-Japanese war, allowed foreign direct investors in China to set up factories. According to the most-favoured-nation agreements, this privilege was extended to other foreign nations. Therefore, foreign capital very quickly flowed into China after 1895 , and stimulated the growth of modern industry.
} 
transportation, money and finance, and communication (Brandt et al., 2014; Y. Chang, 1989; T. Rawski, 1975, 1989; J. Wang, 1955; Wright, 1992). These developments remarkably reduced transportation costs, communication speed and financing difficulties; as a consequence it largely eased and supported economic growth in other sectors, such as manufacturing. Foreign investors and Chinese-owned companies shared these achievements in the booming industrial sector; the best illustration comes from Bergère, who identified this period as the 'golden age of the Chinese bourgeoisies' (Bergère, 1986). Echoing these historical narratives, estimates of industrial development indicate a similar picture of promise. The national industrial output index constructed by Chang shows a respectable double-digit annual real growth rate, while Rawski estimates the growth rate as 8.1 for the modern industrial sector before 1937 (J. Chang, 1955; T. Rawski, 1989).

Unfortunately, even though the modern industrial sector grew so rapidly, it had started in the late $19^{\text {th }}$ century from a small base, and after a few decades of substantial growth, it was still small in the context of the Chinese economy as a whole, accounting for less than 3 percent of GDP (T. Rawski, 1989, p. 9), and 13 percent of the aggregate industrial output figure in 1933 (T.-C. Liu \& Yeh, 1965, p. 89). Rising industrialisation was not only limited in scope, but its geographic coverage also remained regional and not national, in that 80 percent of modern industry was concentrated in the Yangzi delta ${ }^{49}$ and Manchuria $^{50}(\mathrm{Ma}, 2008)$. For instance, 50 to 60 percent of cotton spindles, which were among the most important exports from China through the early $20^{\text {th }}$ century, were located in Shanghai; more illustratively, half the national electricity in the 1920s was generated in Shanghai (Ma, 2008). Similar patterns can be observed in Manchuria as well; a region with 8 percent of China's population contributed almost a third to its factory production and over 43 per cent to the value added by modern transport (Eckstein, Chao, \& Chang, 1974). ${ }^{51}$ In a nutshell, such a small and regionally concentrated modern industrial sector barely skimmed the country's ocean of labour.

\footnotetext{
49 The Lower Yangzi Delta used to be known as Jiangnan, which is part of Jiangsu and Zhejiang province. Many historical studies suggest that this region had a long history of commercialisation and economic activities, making it the largest economic centre in China since the Song period. The lower Yangzi Delta also occupies a central place in recent revisionist literature, but this is beyond the scope of this thesis.

${ }^{50}$ Manchuria in the northeast of China is now known as the three Northeastern provinces. The rapid industrialisation in Manchuria since the late $19^{\text {th }}$ century was based on the development of an open frontier, and, more importantly, it was dominated by Japanese activities. After 1932, Manchuria was fully controlled by Japan and functioned as an essential source of raw materials for Japan's military expansion in Asia.

${ }^{51}$ Due to a lack of data, the author derived this percentage figure based on the 1941 output in Manchuria and in China in 1952 (in comparable prices).
} 
The overwhelming majority of the population were still rooted in agriculture (Chien, 1950, pp. 11-12). In 1933, Liu and Yeh estimate that about 80 percent of the workforce still engaged in agricultural production; but, unlike modern industries, the agricultural sector experienced much modest growth in both productivity and output. ${ }^{52}$ In the same vein, scattered small-scale historical evidence confirms similar results. For instance, data from 7 counties in Zhili province indicate that more than 80 percent of households engaged in agricultural production between 1928 and 1934 (T. Perkins, 2002, pp. 25-26). ${ }^{53}$ Putting this figure into international perspective indicates how far China's economic structure lagged behind. For instance, in the 1870s the share of employment in the agricultural sector in the UK was only 20 percent, and in the 1930s this number fell to 7.6 percent. Even the strong agricultural sector of the US took up only 50 percent of the country's labour in the late $19^{\text {th }}$ century, and the number dropped to 20 percent in the 1930s (Broadberry, 2004).

Table 1.3: Labour force and GDP composition of China, in 1933

\begin{tabular}{lcccc}
\hline & \multicolumn{2}{c}{$\begin{array}{c}\text { Employment } \\
\text { (million) }\end{array}$} & \multicolumn{2}{c}{ Domestic product } \\
& \multicolumn{2}{c}{${ }^{54}$} \\
\hline Agriculture sector & 204.91 & $79.05 \%$ & 18.76 & $62.78 \%$ \\
Non-agricultural sector & 54.3 & $20.95 \%$ & 11.12 & $37.22 \%$ \\
$\quad$ Handicrafts & 15.74 & $6.07 \%$ & 2.04 & $6.83 \%$ \\
Factories, mining, modern transportation & 2.38 & $0.92 \%$ & 1.41 & $4.72 \%$ \\
Finance & 0.14 & $0.05 \%$ & 0.21 & $0.70 \%$ \\
Trade & 14.88 & $5.74 \%$ & 2.71 & $9.07 \%$ \\
Government & 5.12 & $1.98 \%$ & 0.82 & $2.74 \%$ \\
\hline \hline
\end{tabular}

*Source: (T.-C. Liu \& Yeh, 1965, pp. 37-70)

To summarize, there is no denying that the modern industrial sector expanded rapidly, but, because of its small share in total and the geographic concentration of its location, the

\footnotetext{
${ }^{52}$ Due to inadequate data including acreage, yield or productivity, and because of the remarkable diversity in agriculture across China, scholars hold quite different interpretations of how much agriculture output and productivity increased in the course of this period. Rawski holds a very positive view, with extensive spill-over from modern industry pushing the exceptionally rapid economic growth into traditional sectors (Brandt et al., 2014; T. Rawski, 1989). However, there is no solid data to suggest that there was a 'take-off' towards sustained growth in the aggregate output in agriculture before 1949, because no significant technological breakthrough occurred in agricultural production in this period. (Feuerwerker, 1986).

${ }^{53}$ It is true that a proportion of peasants also produced handicrafts to supplement their income, but the way the industrial operation was organised can only be referred to as proto-industrialisation, and not modern industry. The proportion of people who reported that they engaged in handicraft production varied significantly, from $2 \%$ to $60 \%$; therefore, it is very difficult to give a definitive conclusion on this point.

54 The domestic product by industrial origin is presented in constant 1933 precise.
} 
booming industrial development did not alter the composition of labour force on any large scale; in other words, the demand for skilled labour increased to only a limited extent throughout this period.

\subsubsection{Child labour in booming industrialization}

One of the potential outcomes of expanding the modern industrial sector that is relevant to education is a prevalence of child labour, a matter which cannot be neglected. Global evidence shows that the rise of modern industry, the silk and cotton industries in particular, hold back improvements in educational outcomes, because the opportunity cost for children in such contexts tends to be higher (Goldin, 1998). Can a similar pattern be found in China in the early stages of its industrial development? First, given the size of modern industry through this period, child labour cannot have been as prevalent as in the comparable period in the UK and US. In addition, given the large reserve of adult unskilled labour in China; children were not a leading choice for manufacturers.

It is true that many observers at that time vividly recorded tragic scenes of children aged between 7 and 12 years working outside factories (J. Wang, 1955, pp. 1281-1286). ${ }^{55}$ But the number of child workers has not been fully estimated. We infer from a wide range of smallscale surveys targeting working class households a glimpse of life for workers in China during the Republican period. They provide us with important information - the structure of workers' age in its modern factories. The variety of modern industries was limited, including only manufacturing, railway, mining, shipping and banking (Wright, 1992, p. 32); and we find that the composition of under-age workers largely depends on the nature of the industry. ${ }^{56}$ The railroad industry and mining show very low proportions of child labour, with 2 percent of the total workers under the age of 20 . This is not surprising, given the high

\footnotetext{
${ }^{55}$ Wang records the prevalence of child labour working in Shanghai factories for no wage but 2 free meals and a place to stay at night.

${ }^{56}$ Table: The proportions of child labour in China in the 1930s (W. Li, Xia, \& Huang, 2006)

\begin{tabular}{lccccc}
\hline \multicolumn{1}{c}{ Wuxi } & Wuhan & Tanggu & railway & Administrative staff \\
\hline Youngest age & 11 & 10 & 13 & 14 & 14 \\
\hline Share of aged under $\mathbf{1 5}$ & & & & & \\
$\quad$ male & $2.52 \%$ & $6.21 \%$ & 0 & & \\
$\quad$ female & $10.54 \%$ & $21.93 \%$ & $6.09 \%$ & & \\
$\quad$ total & $5.21 \%$ & $10.15 \%$ & $3.08 \%$ & $2.25 \%$ & $0.98 \%$ \\
\hline Sample size & 691 & 1074 & 227 & 178 & 102 \\
\hline
\end{tabular}
}


physical requirements imposed by the nature of the work. The figure for manufacturing was slightly higher, among female workers in particular. However, the youngest child labourers found were no younger than 10 or 11 years of age, suggesting that even in the textile industry, which contained most child labour, a negative effect might be imposed on secondary school students rather than primary pupils. In short, the thriving modern industries were not the main labour pool for child labour, whereas the proto-industries where children and women worked in small-scale and scattered workshops remained the potential job market for most children(W. Li et al., 2006).

\subsubsection{The dynamic relationship between education and the economy}

The previous sections set out several key features of the economic development through the period under discussion, and the last section of this chapter seeks to generalize the dynamic relationship between education and economic demand. Briefly, what should we take away from such a mixed economic outcome? Did economic conditions lay a good foundation for the rise of a modern schooling system?

The dynamic of education and economic development can be summarized as follows: the demand for skills caused by economic structural change increases the return to education, while educational progress eventually drives up the supply of educated workers, thereby reducing the skilled wage (Goldin \& Katz, 2008). Looking at the Chinese context, there is no literature directly estimating the return to education for each level of schooling, ${ }^{57}$ However, Yan's pioneering work on the skills premium in China provides us with essential clues for guessing the dynamics of such a movement. According to Yan, from 1840 to 1900 the wages for skilled workers, defined as people receiving at least an equivalent training to secondary schooling, ${ }^{58}$ increased markedly, demonstrating that there was higher demand than supply for educated labour (S. Yan, 2007). However, the skills premium profile stagnated between 1900 and 1920, then declined slightly in subsequent decades (S. Yan, 2007). In other words, the demand for secondary education, perhaps triggered by the boom in modern industries, rose quickly in the late $19^{\text {th }}$ century, and was gradually met by the increasing supply of talent due

\footnotetext{
${ }^{57}$ There is no census or individual level survey data that includes questions about both income and education for this period.

${ }^{58}$ This definition is congruent with the description of occupations in the category of skilled worker.
} 
to the schooling expansion after the beginning of the $20^{\text {th }}$ century. ${ }^{59}$ At the same time, the wages of workers who had obtained some basic education, show little change through this period. ${ }^{60}$ Without estimates of the return to primary schooling, it is difficult to provide any conclusive argument, but there is no direct evidence indicating that there was an increasing demand for skills failed to be met by the limited supply of educated labour, which caused a notable rise in the return to education.

In short, after its opening up to the global market in the late 19th century, China enjoyed substantial expansion of its modern industrial sector and a modest economic growth. However, because of the narrow scope and limited geographic coverage of its industrialization, no full-scale structural transformation was witnessed in China. It meant that large segments of the country, its hinterland and rural population in particular, continued as agrarian economies with strong elements of proto-industrialisation. The enduring agricultural economy meant limited change in the demands for new skills and talents; therefore, even if the demand for skilled labour did increase, the effect was not large enough to generate a demand-driven education movement. Another issue that cannot be ignored is that education demand differed substantially across regions, because of regional dispersion in terms of economic development and industrial location. In Chapter Four, regional stories of the rise in education over the $20^{\text {th }}$ century in China will be further analysed.

\section{Concluding Remarks}

This chapter sets the scene for the remaining ones by introducing the historical, political and economic background of the birth of a modern schooling system in China. The modern education model was founded in China through a time of turbulence. Western imperialism and the rise of Japan affected China profoundly from the late $19^{\text {th }}$ century onwards, leading to a series of Western-influenced economic, political and social reforms. The remarkable educational movement was one of the many institutional responses to the wide-ranging changes, in particular the newly emerging ideological and political demands, but it was rooted in a fragmented, if not chaotic, political environment and a largely agrarian economy.

\footnotetext{
${ }^{59}$ Enrolment rates in secondary schools rose too late in the period to have much of an effect on the wages of skilled workers.

${ }^{60}$ In Yan's definition, positions that required basic literacy, such as office assistant, office boy and watchman, counted as unskilled (S. Yan, 2007).
} 


\section{Chapter 2 : The journey: towards a modern education system in China}

After setting out the historical background, I want in this chapter to outline China's journey towards establishing a modern education system. From the late $19^{\text {th }}$ century, the country had been calling for a new education model with the aim of transforming the classic Confucian traditional teaching system into a systematically organised, professionally staffed and publicly financed new system. Once the new system, modelled on those of Western countries and Japan, was set up, it expanded very quickly across the country. In the following sections, I briefly introduce the traditional education system that the new model was to transform. Then I discuss separately the three essential features of the modern education system, followed by summarizing a few of the far-reaching merits of the new educational model. The last section focuses on the funding channels of the modern schools.

\section{The burdens and legacy of the past}

Imperial China's long written history and its Confucian culture, coupled with perhaps one of the most sophisticated literati-bureaucrat systems in the world, for centuries determined the essence of what the Chinese chose to view as 'education'. Such a deeply-rooted past constituted the basis of the modern education system in China; it was therefore not possible to separate these two altogether. Classic Confucian education operated in China for over a thousand years. The most distinguished characteristic of this schooling system was that its foremost purpose revolved around one single institution: the Imperial civil service examination. ${ }^{61}$ The extraordinarily high economic and social rewards attached to success in this exam made the pursuit of education a hallmark of Chinese society. Such a link between education and upward social mobility with exceptionally high financial rewards reinforced

\footnotetext{
${ }^{61}$ The Imperial Civil exam was implemented as early as the Tang Dynasty (618-896) and had existed for more than 1000 years before its abolition in 1905. This exam system served to draw the top national talents to become bureaucrats and this had a deep influence on Chinese society. In fact, the university entrance examination system in contemporary China evolved indirectly from the imperial one.
} 
the demand for education, which also laid the ground for the extraordinarily high cultural value placed on education among the people. ${ }^{62}$

The Imperial Court meticulously crafted and monitored the Imperial examination, which served the function of choosing bureaucrats from the best candidates. Through this mechanism of passing several extremely competitive examinations, one could be admitted to a social elite - the class of the gentry. The considerably high returns from education came not only in the form of social privilege ${ }^{63}$ and the official income of a bureaucrat; according to some estimates, grey income might be as high as 14 to 22 times the official salary. This figure meant that about 22 percent of the agricultural output would accrue to a small group of people occupying the top 0.5 percent of the population (Ni \& Van, 2006). ${ }^{64}$ Several studies suggest that, thanks to the outstandingly high returns for success in education, Imperial China, as a pre-modern society, had an exceedingly high demand for schooling which also resulted in relatively high levels of literacy and numeracy (Baten, Ma, Morgan, \& Wang, 2010; E. Rawski, 1979).

At this point, one important question emerges: if the Imperial education system was full of excellence, why did negative accounts of it flourish and the call to replace it with a Western system become so popular from the second half of the $19^{\text {th }}$ century, in particular among enlightened intellectuals ${ }^{65}$ Not only reformers at the time, but also contemporary scholars, indicated that the imperial education system was one of the reasons why China was failing to modernize (Clark \& Feenstra, 2001; Huff, 2003; Landes, 2006; Lin, 1995).

There was no denying that some fundamental weaknesses in the traditional education system were nakedly exposed when China confronted Western and modern forces. Indeed, two major

\footnotetext{
${ }^{62}$ Such a cultural legacy is also widely witnessed across East Asia; all China's Asian neighbours, such as Vietnam, Korea and Japan, used to be influenced by its Imperial examination system.

${ }^{63}$ Many social privileges were granted to members of the gentry class, including exclusion from corporal punishment and corvée (labour service), special arraignment in tax payments, and legitimacy in wearing scholar's robes(C. Chang, 1962, pp. 32-43).

${ }^{64} \mathrm{Ni}$ and Van's calculation implies that the gentry class occupied 0.4 percent of the Chinese population (Ni \& Van, 2006); whereas according to Chang's calculation, the gentry class only comprised the top one to two percent of the entire Chinese population (C. Chang, 1955, p. 102).

65 The pioneers, who first called for remodelling the examination system, were some enlightened scholars and reformists during the late Qing, including Kang Youwei and Liang Qichao. For instance, Liang Qichao wrote in 1886 'there was the deleterious influence of the civil examinations on learning. Most candidates would master whatever curriculum was set on the examinations. . Hence, curricular reform was mandatory to change the learning habits of literati who sought public office" (B. Elman, 2000, p. 598). Later on, more and more scholars, many of who had received education from abroad, joined the wave of urging the educational reform.
} 
shortcomings were widely criticised. First, the narrow focus on Confucian study disincentivised young talent in China from pursuing broad academic achievements, resulting in the retarded development of technology and a modern mentality. The contents of the Imperial examination mainly covered the Four Books, the Five Classics and the ability to write 'eightlegged' essays. ${ }^{66}$ Accordingly, classrooms were dominated by the study of Confucian classics and the writing of unspontaneous essays (B. Elman, 2000, pp. 53-64). Before the 19th century, the gap between Chinese and Western science was already large. The failure to acknowledge a wider spectrum of knowledge, such as the natural sciences or practical expertise, are believed to be one of the essential explanations for China's backwardness in military prowess and industrialisation (Landes, 2006; Lin, 1995; Yuchtman \& Cantoni, 2013). ${ }^{67}$

The other peculiarity of Chinese traditional schooling system was the absence of public provision for basic schooling, which failed to reach many children in the country. One striking feature of the traditional school system was that the government supported elite education rather than basic education (E. Rawski, 1979, p. 24). ${ }^{68}$ Partly because of China's sheer size and large population, ${ }^{69}$ the Chinese Imperial state financed a very small number of academies for advanced scholars. It left the task of spreading basic schooling largely in private hands. ${ }^{70}$ According to Chang, only 0.18 percent of the population ever attended government academies in the course of the late $19^{\text {th }}$ century (C. Chang, 1955, p. 217); otherwise, the task of spreading basic education among the masses had been carried out by

\footnotetext{
${ }^{66}$ The core of the traditional Chinese education curriculum was the value and belief systems in 'Confucian learning' (儒学 ruxue). The curriculum experienced slightly change through time. After the Qing period, it mainly consisted in three parts. (i). A common classical language; (ii) memorization of a shared canon; and (iii). the ability to write elegant essays, known as 8-legged essay (B. A. Elman, 2013, pp. 46-93).

${ }^{67}$ Classical education in Europe between the $16^{\text {th }}$ and $19^{\text {th }}$ centuries shared similar drawbacks to China's in that the curriculum was at first based on religious principles and the medium of teaching was Latin. This education is believed to be distant from both modern scientific inquiry and practical economic life.

${ }^{68}$ The Imperial State certainly encouraged the establishment of a very small number of public schools for basic education - charity schools (义学) and community schools (社学). However, the central government did not allocate any funds for them, and so only a negligible number of them were built. According to Rawski, only 13,400 out of 40 million school-age boys were enrolled in them, providing negligible opportunities nationwide (E. Rawski, 1979, pp. 33-36).

${ }^{69}$ As discussed in section 2.2 of Chapter One, in the domain of education and not only there, the Imperial Court used to be quite reluctant to exert control in all kinds of public affairs and voluntarily withdrew from many public services, ranging from the supply of legal tender to the issuing of commercial regulations. A significant body of literature discusses how Ming-Qing China was actually run by social institutions with little supervision from the state, but this lies outside the scope of the present thesis.

${ }^{70}$ The government academies under the traditional system enrolled only those students, who had already passed several entrance level examinations, to further their studies at the next level. They were equivalent to modernday higher education institutions. They existed mainly in three formats: the Imperial Academy (国子监), prefectural schools (府学) and county schools (县学). These government schools, were few in number, and located only in provincial capitals, prefectural seats and county seats(C. Chang, 1955, pp. 21-43).
} 
households, local communities, lineages and native gentry (Borthwick, 1983, p. 10; P. Deng, 1997, pp. 2-16; E. Rawski, 1979, pp. 24-33). The most widespread educational institution in Imperial China - the Sishu, equivalent to primary school - was purely private; and almost all school-age children in traditional China received some education in a Sishu (P. Deng, 1997, pp. 6-8; E. Rawski, 1985, pp. 24-33). ${ }^{71}$ As the expenses incurred in preparing for the civil service examination could be substantial (B. Elman, 2000; Shiue, 2013; Yi Xu, Holdvari, \& Leeuwen, 2013), the lack of public education provision for the lower level of schooling may have been a critical reason for the failure of schooling failed to spread among vast populations, even though the exam itself seemed to be entirely open and fair to everyone.

In short, owing to its weakness, but also due to the surge in ideological and institutional changes through the late $19^{\text {th }}$ century, this long-standing system came to an abrupt end in 1905. While the traditional education system was outdated, it had in fact laid a solid cultural foundation for the success of the new system, in that education was extremely highly valued in China.

\section{Key elements of the modern education system}

The remodelling of the education system in China was a long journey, through which many plans were drawn up and a number of regulations were established. By the end of the Republican era, the key elements of the modern education system were largely in place. This model contains several major features, namely, an educational model largely supported by public efforts, a high degree of decentralisation, and an emphasis on radical change in its curriculum content.

The first government school in the modern sense was founded in Beijing in 1862, where the main task for students was to learn Western languages (Abe, 1987). ${ }^{72}$ Subsequently, other

\footnotetext{
${ }^{71}$ As the name indicates, Sishu literally means private school ( $S i$ in Chinese means privately-owned).Sishu received no public funds; more importantly, the government never included them under the heading of schools (Xиехiao). This absence of Sishu from the bureaucratic dictionary means that they have no statistical history; hence, we have no idea about the national level of enrolment ratios for traditional primary schooling in Imperial China. Neglecting Sishu had significant consequences for educational policies in the Republican era, too; the Republican government never considered using the Sishu as a basis for the new school system; this led to limited success in promoting mass primary education in China during the early $20^{\text {th }}$ century.

${ }^{72}$ Tongwen Guan (同文馆) was the first modern school built by the Chinese government. It served an important function in introducing Western knowledge to China. It became part of the Imperial Capital University (now Peking University) in 1902. Unfortunately, even with significant support from both the Qing court and Western
} 
modern schools flourished in China. However, the strong impulse to reform was not content with a small number of new schools, and continued to urge wide and thorough changes. In 1902, the very first piece of legislation on modern education was issued by the Qing Court, which largely emulated Japan's policies. The Education Act of 1902 outlined the general foundation of the first modern educational system in China (Huaxing Li, 1997, pp. 74-94; Shu, 1928, p. 6; Yang, 1934, p. 421). ${ }^{73}$ It was an unrealistic blueprint, which failed to provide concrete guidance to show how an education system should be instituted and implemented in the Chinese context; in consequence, it was never put into practice. However, as the first government-promulgated Education Act, it still demonstrated an official commitment from the state to a brand new education model. The most significant development on the road to the new educational model occurred two years later, when a slightly revised version of the Education Act was passed in 1904. Its implementation on a national scale marked the official start of the modern education system in China (Huaxing Li, 1997, pp. 98-118). ${ }^{74}$ On 2 September 1905, a memorandum was finally endorsed to discontinue the civil service examination system at all levels in the following year(C. Chang, 1955, pp. 208-209), thus officially ending the long-lived traditional education system, and more importantly deeply altering the nation's chief incentive for receiving education. As pointed out, the collapse of the Qing dynasty in 1911 did not stop the state from trying to set up a new education system; on the contrary, it was pushed repeatedly by subsequent regimes throughout the first half of the $20^{\text {th }}$ century, through which three more Education Acts were legislated. ${ }^{75}$

In short, through the first half of the $20^{\text {th }}$ century, five Education Acts in succession were passed. During a time of political turmoil, it is still an open question how seriously these education acts were implemented in practice, yet the ambition and aspiration of the state were

powers, the Chinese people were not ready to endorse this new type of education; therefore, the school encountered considerable difficulty in attracting students.

73 The Education Act 1902 (钦定学堂章程), also known as 壬寅学制 and drafted by Baixi Zhang, is made up of six chapters. Specific regulations on Higher Education, Secondary Education, Primary Education, and the criteria for entering higher grades are all covered in a corresponding chapter. It was further amended by Zhidong Zhang and Qing Rong in 1903 (Huaxing Li, 1997, pp. 74-84).

74 The Education Act 1904 (奏定学堂章程), also known as 癸卯学制, drafted by Bixi Zhang and Zhidong Zhang, includes 18 chapters which provide more of a grounded legal and administrative foundation for implementing the modern educational system in practice (Huaxing Li, 1997, pp. 74-84).

75 The Education Acts 1912 and 1913 were combined and are referred to as 壬子学.制 With some slight revisions in the following year, the combined version remained intact for the next decade, and was only replaced by the Education Act 1922 passed by the Beiyang Government, which is also known as 壬戌学制(Huaxing Li, 1997, pp. 98-110).. The last Education Act was legislated under the rule of the Nanjing Government in 1928, known as (中华民国学校系统), its content was that of the previous one with virtually no adjustments (Huaxing Li, 1997, p. 153) 
at least loud and clear. Altogether, they provided a roadmap and laid regulatory foundations for the new education model from many perspectives, including the administrative arrangements, the educational provision and the structure of education. In the following sections, these features of this new education model are described in turn.

Table 2.1: Education Acts passed through the first part of the $20^{\text {th }}$ century

\begin{tabular}{l|l|l}
\hline Act & Passed by & \multicolumn{1}{c}{ Major Revisions } \\
\hline Education Act 1902 & Qing Court & $\begin{array}{l}\text { Layout of the legal foundation of the modern education system. } \\
\text { Primary education was not regarded as compulsory, but it } \\
\text { mandated the local gentry to support primary schooling. } \\
\text { Failed to be implemented. }\end{array}$ \\
\hline Education Act 1904 & Qing Court & $\begin{array}{l}\text { The first education act was put in practice. } \\
\text { Very similar to the Education Act 1902 }\end{array}$ \\
\hline Education Act 1912 & $\begin{array}{l}\text { Nationalist } \\
\text { Government }\end{array}$ & $\begin{array}{l}\text { Compulsory lower-primary education } \\
\text { first time. } \\
\text { Equal educational opportunities for female students in primary } \\
\text { school were instituted. }\end{array}$ \\
\hline Education Act 1922 & $\begin{array}{c}\text { Beiyang } \\
\text { Government }\end{array}$ & $\begin{array}{l}\text { Initiated by provinces, a change in the structure of schooling to } \\
\text { 6-3-3 years. }\end{array}$ \\
\hline Education Act 1928 & $\begin{array}{l}\text { Nationalist } \\
\text { Government }\end{array}$ & No major adjustments compared to the Education Act 1922 \\
\hline
\end{tabular}

\subsection{Educational Organisation}

In order to better understand modern education, we start our analysis by focusing on the administrative structure under this new educational system. Two questions are addressed in this section. First, how did educational organisations operate under this new system? Next, what responsibilities and authorities did each of them have?

\section{Central level:}

At the central level, there had never been a government board directly responsible for education until the early $20^{\text {th }}$ century. ${ }^{77}$ In 1905 , the founding of the Ministry of Education

\footnotetext{
${ }^{76}$ The Ministry of Education made education for the first time in 1915, as one revision clause to the Education Act 1912, and specified that lower primary schools should be attended for four compulsory years (F. Wang, 1994, pp. 466-468).
} 
(学部 Xиеbu) marked the advent of central control in education. Later during the Republican era, the name changed several times, settling as the National Board of Education for much of its history (Huaxing Li, 1997, p. 391; F. Wang, 1994, pp. 1-7). ${ }^{78}$ There were two main responsibilities for the education office at central level. One was to directly finance and manage all the public universities across the country, granting scholarships to overseas students, and a very small number of secondary schools. In addition, an individual inspection department was created under the National Board of Education to supervise local educational affairs (F. Wang, 1994, pp. 1-7).

\section{Provincial level:}

Similarly, a separate education bureau, as one of five bureaus, ${ }^{79}$ was set up at the provincial level, and run by a provincial governor after 1905 (C. S. Li, 1922, p. 42). The responsibility of the provincial education bureau included directly supporting secondary education within its administrative boundary, and supervising the development of county level education (Huaxing Li, 1997, pp. 398-404; F. Wang, 1994, pp. 282-283). Another important force operating in the education sector was that of the provincial educational commissioners (视学 Shixue), who were directly appointed from Beijing (Huaxing Li, 1997, p. 432). ${ }^{80}$ However, as mentioned, central control was limited and the state rarely contributed to fundraising for local education; therefore the functions of the commissioners were limited in practice. Other than government organisations, powerful civil organisations also functioned in the field of education, and this made the separation of educational authority at the provincial level more ambiguous. For instance, the provincial education association, a professional self-governing organisation, was exceptionally influential, ${ }^{81}$ notably in provinces where regional elites were strong. In these cases, this civil educational organisation assumed many responsibilities, in

\footnotetext{
${ }^{77}$ No separate board of education existed before 1905. The Imperial Exam was the only educational field that the Government engaged in. The examination was under the jurisdiction of the Board of Rites ( $\mathrm{Li} \mathrm{Bu}$ ); at the same time, the money needed for administering the exam was supplied by the Board of Finance ( $\mathrm{Hu} \mathrm{Bu})$.

${ }^{78}$ In 1927, a reform was initiated by a few high-ranking intellectuals. Modelled on that of France, the National Board of Education changed to a series of académies (大学区) as the highest administrative organisations in charge of educational affairs. Such a reform was intended to reduce the political and bureaucratic influence on educational affairs; but it largely neglected the role of primary and secondary schooling. After two years of immature experiment, this reform came to nothing in the end, and the old system was brought back in 1929.

${ }^{79}$ The provincial governor's office was divided into five bureaus: general affairs, miscellaneous affairs, civil administration, industry, and education (C. S. Li, 1922, p. 42)

${ }^{80}$ In total, three independent commissioners in the provincial governor's office were directly appointed from Beijing; one was an educational commissioner. They were there to represent the Ministry of Education (or National Board of Education), and were supposed to supervise and report educational performance back to the central offices (C. S. Li, 1922, pp. 42-43).

${ }^{81}$ Provincial education association was established and flourished at the end of the Qing dynasty as an attempt to incorporate elite power into the court's agenda.
} 
terms of promoting education, for the provincial education bureau, and sometimes received large subsidies from provincial budgets (Chauncey, 1992, pp. 102-107). In a nutshell, multiple organisations for educational affairs coexisted at the provincial level, where the boundaries of responsibility and authorities for different organisations were implicit, and determined by the outcomes of a higher level power struggle> This partly explains why the situation varied substantially across provinces.

\section{Local level:}

In 1906, the Qing Court enacted a decree calling for the establishment of local education exhortation bureaus (劝学所 quanхиеsuo) in every county. These were responsible for every aspect of modern primary education (Huaxing Li, 1997, pp. 439-444; Yang, 1934, pp. $33,421)$. The name of this institution literally means 'persuading people to learn'. After 1922, the education exhortation bureau altered its name to the Local Board of Education, but its real function in practice remained similar. There is no doubt that primary schooling constituted the major component of modern schooling through the early $20^{\text {th }}$ century. Therefore, the county board of education, which undertook the foremost responsibility in primary education, constituted the backbone of the educational organisations in China in this development.

As discussed in section 2.2 of Chapter One, an important feature of the local board of education was its large autonomy. Not only did the county education bureau enjoy extensive autonomy in terms of decision making power in the sector of primary schooling, it also encountered exceptionally low levels of supervision and monitoring from above. Its chief officers and staff were appointed from the local gentry, ${ }^{82}$ and were not state officials (Chauncey, 1992; Keenan, 1994, p. 111). ${ }^{83}$ That is to say, every aspect of primary education, including the critical fundraising and daily operation of schools, was managed by members of local educated elites, not state officials.

To summarize, in terms of governmental organisation, the education system was formulated as a three-tier structure. The distribution of responsibility was clear in the central control of higher education, provincial control of secondary education, and local boards of education for primary schooling.

\footnotetext{
${ }^{82}$ In most cases, the chief officers of the education hortatory bureaus had no official salary and the positions were filled by respectable local gentry.

${ }^{83}$ How was primary schooling financed, managed and promoted by local government and social forces? How were local gentry involved in local governance? These questions will be further explored in Chapter 4
} 


\subsection{Access to education: Increasing importance of public schools}

As emphasised in the preceding discussions, the foremost feature of the modem education system lay in the increasingly important role it gave to the government. Unlike the limited role that the state had played in Imperial education from the very first, both the Qing Court during its last decade, and the regimes that succeeded it showed their desire to create in China a public education system to allow schooling to reach as many people as possible. From records on educational outcomes, it is clear that the nationwide expansion of modern schooling through this period was predominantly driven by the rise of the public efforts.

There are many ways of demonstrating the role of the government in education. First, one commonly seen indicator is the support ratio: government education expenditure as a share of GDP. No data are available on either of these indicators; therefore, the second best option that we can turn to is the share of publicly controlled schools. One thing that should be borne in mind when interpreting this ratio is that a 'publicly controlled school' was not synonymous with a 'publicly funded school'. ${ }^{84}$ Since private schools could receive public subsidies, public schools could equally benefit from private funding, including high tuition fees and private donations. In the early $20^{\text {th }}$ century China, limited tax revenues meant that most public schools under government ownership and control required tuition fees and private donations to make up their budgets. Accordingly, the term 'public school' in this thesis is more likely to refer to schools which were publicly provided, but not necessarily fully reliant on public funding.

First, as regards primary schooling, public primary schools were the main contributors. ${ }^{85}$ They were dominant in number at the very beginning of the $20^{\text {th }}$ century and became

\footnotetext{
${ }^{84}$ Public school' is not at all synonymous with the phrase 'publicly funded school'; they are entirely different concepts. The use of the term 'financed' or 'funded' emphasises the party which generated revenues (mostly through taxes) and directly pays for school inputs. When it comes to education provision, this concept is more related to the party which constructed schools, established the curriculum and supplied instructional materials (Le \& Meleisea, 2013). That is to say, education provision has a slightly broader frame of reference, and its tasks include capital investment in the buildings, hiring teachers, selecting the curriculum and so on. Education funding, on the other hand, concentrates only on the source of funding (Goldin, 2015).
}

${ }^{85}$ From the late Qing until 1949, four main types of primary school were existing together and delivering similar
functions: public primary schools, registered private primary schools, non-registered private schools, and the
long-lived traditional schools - sishu. Neither the government reports nor various surveys at the time contains
information on the latter two; therefore, the data presented in this chapter exclude these types of institution,
focusing only on the public and registered private primary schools. There is no denying that the significantly
large proportion of public schools has something to do with the biased reporting system where non-registered
private schools and Sishu were not documented properly. However, since there is no guarantee of the quality of 
increasingly prevalent. In 1946, public primary schools accounted for almost 95 percent of the total, demonstrating the dominant contribution of public primary schools to the diffusion of mass education among people in China throughout the early $20^{\text {th }}$ century.

Figure 2.1: Primary schools (public vs. private)

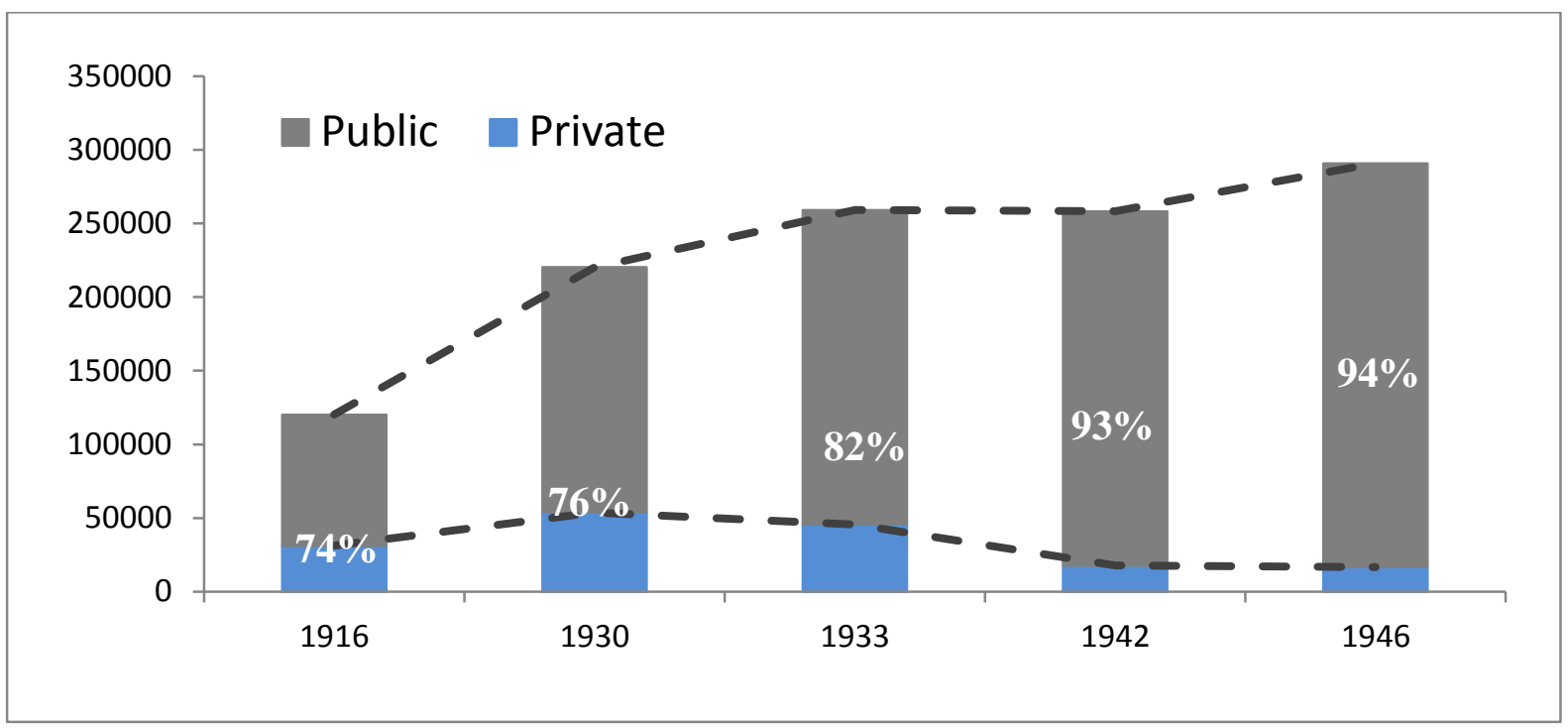

*Sources:

(i). (Zhonghua minguo jiaoyu tongji tubiao (The education statistic report for Republic of China, fifth) 1916)

(ii). (Quanguo Chudeng Jiaoyu Tongji (The statistic report on primary education) 1930)

(iii). (Quanguo Chudeng Jiaoyu Tongji (The Statistic Report on Primary Education in 1933), 1937)

(iv). 1946: (Zhu, 1948)

If we turn to higher education, a slightly different pattern emerges for both secondary and tertiary schooling. The number of public secondary schools rose substantially throughout the first half of the $20^{\text {th }}$ century, but as a share of all schools, they declined from 87 percent in 1912 to 61 percent in 1945 . The loss of importance of public secondary schooling reflects variance from what we observed in primary education, i.e. the rise of secondary education was mainly boosted by private provision and demand. In the same way, the number of universities and colleges did not increase markedly, while the share of public universities ranged from 51 percent to 70 percent. $^{86}$

education in the non-registered primary schools and Sishu schools, we can at least claim that public schools completely dominated formal primary education.

${ }^{86}$ In 1936, nearly half the university students had previously enrolled in private schools, but the ratio had dropped to $31.4 \%$ by 1946 . 
In summary, the wider access to education in China during the late Qing and Republican era was mainly due to the increasing number of public schools. More importantly, contrary to the practice of Imperial China, the limited public financial resources were mainly allocated to lower levels of schooling, to prepare a larger pool of literate labour; to the progress at secondary and tertiary levels, the private sector served as a more important contributor.

Figure 2.2: Secondary schools (public vs. private)

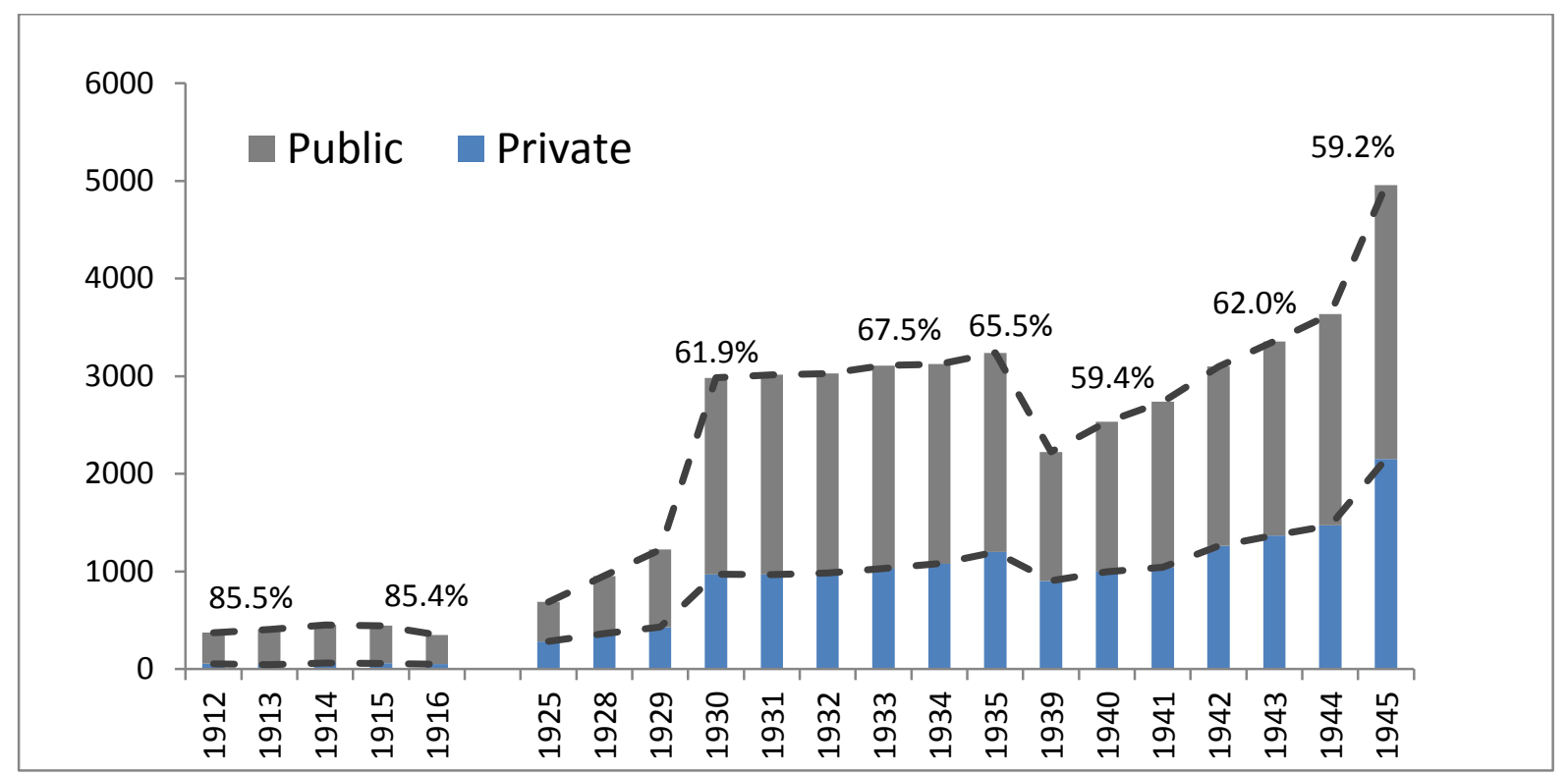

*Source: (Yang, 1934, p. 193; Zhu, 1948, pp. 1429-1430)

Figure 2.3: Tertiary schools (public vs. private)

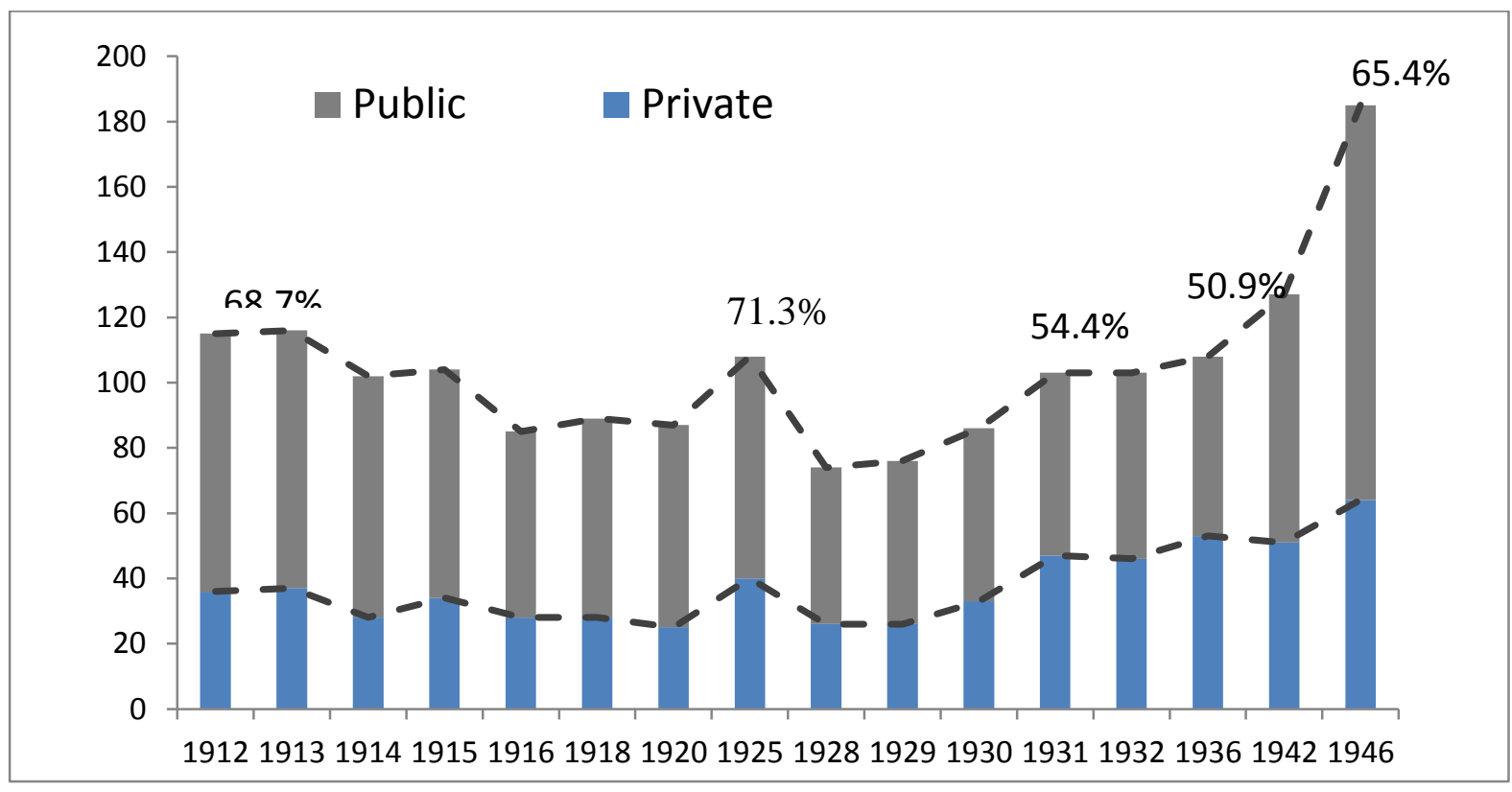

*Source: (Yang, 1934, pp. 22-23; Zhu, 1948, p. 1406) 


\subsection{Decentralised Structure of the new education system}

Another key feature of the new education system was its decentralisation. Of the many attempts to define educational decentralisation, we simply specify that an education system can be considered decentralised when the authority to do a range of things - revenue generation, spending autonomy, personnel control, and curriculum design - is assigned to lower levels of government (Fiske, 1996, p. 10).

An extensive literature discusses the virtues of a decentralised education system, most of all in the early stages of development. Local communities which are equipped with the best knowledge about their own locality can arguably guarantee higher efficiency; for instance, educational resources can be spent by them in a way that better fits the preferences of the residents. At the same time, local government also has an advantage when it comes to monitoring, say, the performance of schools, headmasters and teachers. According to historical studies, successful practice in European nations and the US through the early phase of the rise of schooling largely relied on a decentralised education system (Black \& Sokoloff, 2006; Goldin \& Katz, 2008, pp. 136-139; Lindert, 2004a, pp. 115-117). Furthermore, the decentralised education model has been passionately advocated by many contemporary international organisations, as a path to improve education in the developing world (WorldBank, 2004).

Measurement of education decentralisation can be problematic. As suggested in its definition, authorities of many kinds are associated with a country's system of education. Only when all of the above authorities are monopolised by the central level is the system considered highly centralised, while if all educational decisions are made at the local level, the system is highly decentralised. However, the reality is more complex, and many systems are partly decentralised and somewhere between the two extremes (Le \& Meleisea, 2013). Therefore, what matters more is which decisions are made by a central educational ministry, and which emerge at local level. In China's case, except for curriculum design, which was highly centralised, other educational decisions were local.

Furthermore, the degree of decentralisation can also differ from one schooling level to another. As pointed out in section 2.1 of this chapter, successive Education Acts through the early $20^{\text {th }}$ century outlined clear regulations regarding the allocation of responsibility by level 
of education, where central government undertook to deliver tertiary education, while the state delegated responsibility for secondary schooling to the provincial government, and primary schooling to county and sub-county governments. Accordingly, the degree of decentralisation rose as the level of schooling went down.

Table 2.2: School by management, 1910s-1940s

\begin{tabular}{|r|r|r|r|r|r|r|r|r|r|r|}
\hline \multirow{2}{*}{ Year } & \multicolumn{3}{|c|}{ Tertiary school (\%) } & \multicolumn{3}{c|}{ Secondary school (\%) } & \multicolumn{4}{c|}{ Primary school (\%) } \\
\cline { 2 - 12 } & national & provincial & local & national & provincial & local & national & provincial & county & grass root \\
\hline 1916 & 16.9 & 83.1 & 0 & 0.5 & \multicolumn{2}{|c|}{99.5} & 0.04 & \multicolumn{3}{|c|}{99.96} \\
\hline 1930 & 32.1 & 67.9 & 0 & 0.7 & 25.5 & 73.8 & 0.01 & 0.01 & 35.01 & 64.17 \\
\hline 1933 & 49.1 & 50.9 & 0 & 0.8 & 26.9 & 72.3 & 0.01 & 0.01 & 21.05 & 78.19 \\
\hline 1940 & 66.1 & 33.9 & 0 & 4.6 & 35.2 & 60.2 & 0.01 & 0.01 & 50.99 & 48.82 \\
\hline 1945 & 64.4 & 35.6 & 0 & 3.9 & 30.5 & 65.5 & 0.02 & 0.02 & \multicolumn{2}{|c|}{95.76} \\
\hline
\end{tabular}

*Sources:

(i). Primary: the sources noted under Figure 2.1 (ii). Secondary: (Zhu, 1948, pp. 1429-1430)

(iii). Tertiary: (Zhu, 1948, p. 1402)

As discussed, the ideal way to measure the degree of decentralisation is to ask where the decisions are made in regard to a long list of areas, namely, covering personnel control, core curriculum, school location, and so on, at each level of schooling. Nonetheless, in reality, we are constrained by the limitations of the evidence and it is impossible for us to provide detailed data on each aspect. The most critical indicators that we can apply refer to decentralisation in terms of educational finance. Among the range of administrative decisions, revenue generation played the essential role and dominated the further allocation of authority for other things. Economists tend to give special attention to educational finance to measure the extent of decentralisation. One commonly used method is to look at the percentage of educational revenues that come from local sources. In the Chinese case, the limited information regarding the composition of educational revenue means that we have to resort to something different - the composition of public schools by ownership instead of revenue source. The classification in Tables 2.3 and 2.4 are mainly attributed to ownership and the source of administrative control, but not financial source. For instance, classifying a school as 'provincial' did not necessarily indicate that it would be entirely financed from a provincial budget. It may have been subsidised by central government and/or private donations. 
In Table 2.2, several important patterns appear. Tertiary education, inconsistently with the Education Act, was not highly centralised, and control of more than half the public universities or colleges was delegated to provincial government. The situation altered only after the full-scale Japanese invasion in 1937, because of the special wartime arrangements that made national budgets more important in the realm of schooling. Similar patterns can be observed in secondary education. According to government statutes, the task of developing secondary education was supposed to be undertaken by provincial authorities, but in fact it was delegated to a lower level. No more than 35 percent of the public secondary schools were classified as provincial schools, leaving the rest of the burden to the county government. Last, primary schooling was a highly decentralised system with almost all public and private primary schools controlled by the lowest administrative units - county and sub-county governments.

International comparisons are recalled to put China's figures into perspective. If we turn to the two world leaders in schooling at the time, roughly 70 percent of Prussia's primary schools were funded by local taxes in the 1880s; the figure was similar for the US, where an untold number of local communities predominated as contributors to the impressive rise in schooling provision. The most decentralised country in Europe was Italy, in that, before the 1880s, 90 percent of primary schools were funded locally, which was a similar level to that of China. In contrast, England lagged behind in terms of schooling, and had a rather centralised schooling system before the 1880s; less than 20 percent of primary schools were financed by local governments (Lindert, 2004a, pp. 116-117).

In short, through the late Qing and the entire Republican eras, the education system remained highly decentralised in China. The degree of decentralisation was not the same across all schooling levels, but was greater at the lower levels. As an expanding schooling system in the early stages of its development, this new system required extensive funding, supervision and management from all tiers of government. With fragmented political bodies and the unequal economic development across regions, China's highly decentralised approach may have been the best possible strategy for developing education at this stage of its development. 


\section{Other benefits of the new education system}

After introducing some basic features of the modern education system, to better illustrate this landmark transformation in the educational history of China and the progress that it brought, this section generalises several major benefits of the modern schooling system. Compared to the old system, it brought a handful of critical advantages, including a shift from informal schooling to formal education, an extraordinary improvement in curriculum design and equal educational opportunities for both genders.

Table 2.3: The difference between traditional and modern education

\begin{tabular}{|c|c|c|}
\hline & Traditional Education & Modern Education \\
\hline Purpose & $\begin{array}{l}\text { Civil Service Examinations } \rightarrow \text { path to } \\
\text { bureaucrat status }\end{array}$ & $\begin{array}{l}\text { Transmitting knowledge and cultivating } \\
\text { competent citizens }\end{array}$ \\
\hline Curriculum & Confucian classics, Confucian doctrines & $\begin{array}{l}\text { Broader spectrum of knowledge, } \\
\text { vocational instruction, new doctrines }\end{array}$ \\
\hline $\begin{array}{l}\text { Main } \\
\text { Features }\end{array}$ & $\begin{array}{l}\text { 1. Civil Service examination oriented } \\
\text { 2. Private provision of basic schooling } \\
\text { 3. Informal system } \\
\text { 4. Educational opportunities for males } \\
\text { only }\end{array}$ & $\begin{array}{l}\text { 1.Dominant public schools } \\
\text { 2. Formal system with an explicit } \\
\text { classification of schooling level } \\
\text { 3. Neutrality towards gender }\end{array}$ \\
\hline
\end{tabular}

\subsection{Formal schooling}

The first critical advance for the modern system was the shift at the turn of the $20^{\text {th }}$ century from informal schooling to formal education. This transformation brought China a much more defined structure with three tracks of schooling and more professionally trained staff.

\footnotetext{
${ }^{87}$ From the Ming dynasty onwards, people who attended the Imperial Examination were required to be students of county or prefectural academies ( $f u$ xиe and xian xue), which were publically financed educational institutes. However, every county was equipped with one county academy at most; and only the students who passed the first level of the Imperial Examination were permitted to enrol. Therefore, by modern standards, the very small number of publically funded educational institutes of county academies and prefectural academies under the traditional system was equivalent to higher levels of schooling, such as secondary schools, if not universities. Thus, the argument that basic education was mostly privately-provided in Imperial China remains robust.
} 


\subsubsection{Defined educational structure}

The Imperial education system had strong elements of informal schooling, including a vague education structure and no clear criteria for teacher recruitment. At the turn of the $20^{\text {th }}$ century, we witness a shift from a sort of Bell-Lancaster method of teaching in which students of different ages studied together in one room with one teacher, ${ }^{88}$ to a schooling system, which separated students according to grade. One may wonder what differences formal schooling could bring. It is true that knowledge is not necessarily transmitted via a formal school system. ${ }^{89}$ However, such informal schooling presents extraordinary inefficiency. ${ }^{90}$ Just as many other institutions established rules and regulations creating predictability, so did the formal school system. In order to give education wide appeal to large numbers of ordinary people, a formal school system, with a clear education structure, was exclusively required. Starting from the Education Act 1904, which was revised many times, an explicit structure emerged.

Table 2.6 displays the evolution of the education structure more graphically. The new tripartite system developed a structure of parallel tracks for general, vocational and normal schools. The multiple schooling tracks diversified the purpose of education. Initially, general education remained the dominant form of schooling. One could spend roughly 19 years of study in general schools to attain the highest available qualifications. At the same time, there was an industrially-oriented option through vocational or technical education. Vocational schooling offered know-how or procedural knowledge for specific trades and occupations. In contrast to general education, it was practice-oriented and relevant to industrial activities. Last, normal education presented a third option, the training of teachers for the expanding modern education system, which was particularly important for females, since teaching

\footnotetext{
${ }^{88}$ The "Bell-Lancaster method" is also referred to as the monitorial system, an education method based on the abler pupils being used as 'helpers' to the teacher, passing on to other students the information they had learned

${ }^{89}$ Informal schooling, such as private tutors passing down knowledge to students, was a prevalent format for elite education, not only in Imperial China but also in Ancient Greece. For instance, Socrates taught Plato, and then Plato taught Aristotle, and so on.

${ }^{90}$ Under the traditional schooling system, one may spend many years in the pursuit of many areas of knowledge examinations without being able to predict the length of one's schooling (B. Elman, 2000; Yi Xu et al., 2013) To best illustrate the unpredictability of the time needed to attain degree level of degree, we need only think of the considerable difference in the age of people passing the examinations. According to historical narratives, among some prestigious officials through the late Qing period, we can see significant differences in this regard. Zeng Guofan passed the prefecture level exam when he was 23, while Li Hongzhang succeeded when he was 17, Zongtang Zuo was 14, and the precocious Liang Qichao was only 11. Studying to pass the first level of the Imperial Exam took on average 10.5 years, for the Juren degree, 16 years, and for the Jinshi degree it could take as much as 1.5 years more, a total of 17.5 years (Yi Xu et al., 2013).
} 
constituted one of the very few acceptable career options. ${ }^{91}$ Among the three tracks, there was no denying that the progress of general schooling dominated the expansion of modern education, occupying 60 to 70 percent of secondary education, leaving vocational and normal schooling as peripheral. ${ }^{92}$

In addition, under each track of education the duration of each level of schooling was clearly regulated. This model was promulgated by the Ministry of Education in the Education Act of 1905, which emulated Japanese arrangements. The system was a 9-4-6 division: primary school for 9 years, secondary school for 4 years and tertiary school for 6 years. Primary education was further divided into kindergarten, lower primary and higher primary, each lasting for 3 years. The structure of education was occasionally altered slightly through the Republican period; during this process, the Japanese influence weakened, due to the military conflict between China and Japan, while the Western influence became more prominent. In 1912, the division became 7-4-4. On 26 October 1921, the education system was changed again to follow the style of the USA, which favoured a 6-6-4 division. This continued until 1949; when Communist China was established; at this point a new system was introduced, copied from the Soviet Union.

\footnotetext{
${ }^{91}$ From 1907, normal schooling for girls was allowed under the new system.

${ }^{92}$ Immediately before the outbreak of the second Sino-Japanese War, the figure of 309,156 registered secondary schools was recorded; for vocational schools, the figure was only 31,592. Similarly, normal school student numbers were slightly higher at 38,795, but still almost a tenth of the students enrolled in general secondary school (Zhu, 1948). The breakdown records on the number of general secondary schools, vocational school and normal school may be found in Chapter 2, Table 2.3.
} 
Table 2.4: Structure of Education

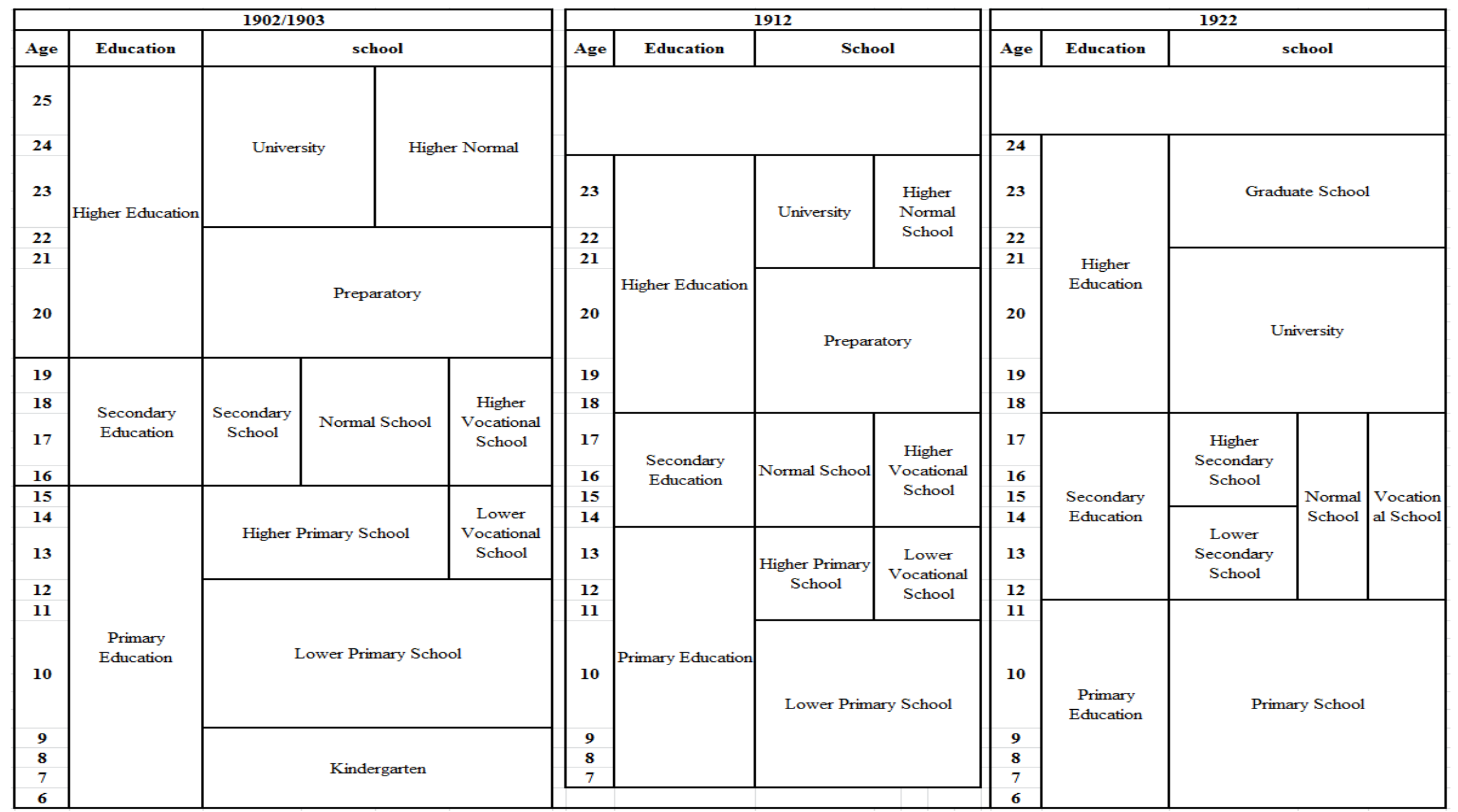




\subsubsection{Explicit regulation on teacher selection criteria}

Apart from a defined educational structure, there were also many attempts to explicitly regulate the recruitment criteria for teachers. Given that one of the principal propositions of the new educational model was to transform educational content, it was essential to appoint eligible teachers who had the academic capacity to deliver the right 'education' to students.

Under the traditional system, most teachers were lower degree holders or those who had failed the civil service exam (E. Rawski, 1979, pp. 42-43). In remote and poor villages, the elders could sometimes directly engage private tutors who had received very limited training (Borthwick, 1983, pp. 14-38; B. Elman, 2000; Gamble, 1954, p. 188). In contrast, the modern schooling system outlined strict eligibility requirements on teachers for each tier of schooling. In their recruitment, educational attainment stood as the main criterion. For a primary school post, only graduates of normal school (equivalent to secondary school) were eligible (F. Wang, 1994, p. 463). For a secondary school post, a degree from a higher normal school (equivalent to university) was required (F. Wang, 1994, p. 283).

Table 2.5: Educational background of primary school teachers, 1946

\begin{tabular}{|c|c|c|c|c|c|c|c|}
\hline & \multirow{2}{*}{ Tertiary } & \multirow{2}{*}{ normal } & \multicolumn{2}{|c|}{ Secondary } & \multirow{2}{*}{ primary } & \multirow{2}{*}{ others } & \multirow{2}{*}{ Total } \\
\cline { 4 - 5 } & & & Senior & junior & & \\
\hline Number & 445 & 66 & 3329 & 9567 & 6472 & 11102 & 30981 \\
\hline Percentage & $1.44 \%$ & $0.21 \%$ & $10.75 \%$ & $30.88 \%$ & $20.89 \%$ & $35.83 \%$ & $100 \%$ \\
\hline
\end{tabular}

Source: (Zhu, 1948, p. 1469)

Unfortunately, what happens in practice when a brand new education model is built from the ground up in a very short time is that teacher availability and quality were among the most common problems. Accordingly, the regulations on the criteria for teachers also specifically noted that exceptions could be made when a school committee approved of a candidate even without the required degree (Huaxing Li, 1997, pp. 513514). In other words, such rules were never fully implemented in practice due to the extremely low number of teachers who could meet these standards. As presented in 
Table 2.7, after decades of education expansion, roughly 80 percent of the primary teachers failed to meet the standard set by the Ministry of Education.

\subsection{Education quality: academic and practical learning}

There is no denying that the foremost improvement in the new education model was that it embraced a much broader academic range in its curriculum, instead of focusing solely on theories of morality and statecraft. As pointed out in section 2.1 of Chapter One, the advent of a modern education system in China was largely driven by the urge to strengthen military might and by aspirations towards state formation. Consequently, exceptional attention was given at the time to changing the educational content. Academic learning, technological know-how and ideological campaigns were emphasised in the new curriculum, which brought magnificent progress in the quality of education.

Since the late Qing period, many new curriculum models have been promulgated for schools to emulate and enrich the knowledge initiated in the classroom. Into the old system, the newly modified curriculum incorporated Western subjects, such as mathematics, physics, geography and foreign languages. Table 2.8 sets out several regulatory models for school curricula by the Ministry of Education from 1904 to 1948. Even though the full implementation of these models in practice was not guaranteed, it still conferred a progressive tendency on curriculum design. It is clear that the major change was the remarkable decline of the emphasis on the Chinese Classics; the class hours required in the total dropped from 35 to 15 percent. In addition, students spent less time studying social science and more time on natural science and manual work. These two lines of change can also be observed in the curriculum models for secondary school education launched by the Ministry of Education.

The second important change in the curriculum was the addition of moral training and cultural uniformity which was emphasised in classes (Kuo, 1913). In the past, education was the vehicle for selecting Imperial officials; therefore classic Confucian education had long encompassed ideological control, including loyalty to the emperor and honour for Confucius. However, under the new system, education undertook the task of spreading and promoting new moral doctrines; instead of promoting obedience and 
loyalty, new doctrines included nationalism, democracy and later the 'Three Principles of the People', which were rigorously pushed through the expanding education system to the masses. ${ }^{93}$ In a nutshell, modern schooling was considered a means of cultivating virtuous citizens for a modern society.

Briefly, the change in curriculum design constituted the most profound and far-reaching transformation in the new education system. The reform was largely Westerninfluenced, leading to the elimination of the Confucian classics as an individual subject, the introduction of new subjects, emphasis on manual work and military drill and the diffusion of new moral doctrines for the new regimes in place of Confucianism.

Table 2.6: Regulatory models for primary school curricula (\%)

\begin{tabular}{|c|c|c|c|c|c|c|}
\hline & 1904 & 1912 & 1922 & 1936 & 1948 \\
\hline \multicolumn{2}{|c|}{ Chinese (Confucian Classics) } & 35 & 20 & 20 & 17.5 & 15 \\
\hline \multicolumn{2}{|l|}{ Maths } & 10 & 15 & 17.5 & 15 & 12.5 \\
\hline \multicolumn{2}{|l|}{ English } & 10 & 15 & 17.5 & 15 & 15 \\
\hline \multirow{2}{*}{ Social Science } & History & \multirow{2}{*}{20} & \multirow{2}{*}{15} & \multirow{2}{*}{15} & \multirow{2}{*}{10} & \multirow{2}{*}{15} \\
\hline & Geography & & & & & \\
\hline \multirow{2}{*}{ Natural science } & Physics & \multirow{2}{*}{10} & \multirow{2}{*}{10} & \multirow{2}{*}{10} & \multirow{2}{*}{12.5} & \multirow{2}{*}{17.5} \\
\hline & Chemistry & & & & & \\
\hline \multicolumn{2}{|l|}{ Art \& PE } & 10 & 10 & 10 & 15 & 10 \\
\hline \multicolumn{2}{|l|}{ Manual work } & 5 & 15 & 10 & 15 & 15 \\
\hline
\end{tabular}

*Source: (Shu, 1928, p. 79)

\subsection{Equal access to schooling: gender neutrality}

Furthermore, the new schooling system carried another critical virtue: it ended the long history of female exclusion from formal education in Chinese society. Gender educational inequality is shared by many developing countries in the early stages of development and culture, and social politics were among the chief contributors to the role of females in the area of education. ${ }^{94}$ Gender neutrality is an advantage which

\footnotetext{
${ }^{93}$ As discussed in the section 'decentralised education', most authority in education was decentralised to a local level in the course of this period. The only exception lay in curriculum development, which was controlled at the central level.

94 Similarly, exceptionally little human capital came from females, a phenomenon which emerged in most of the Asian countries sharing a similar Confucian ideology to China's. Even in Japan, Asia's leading nation in terms of educational development, the gender gap in education remained very wide until the end of World War II (Yoshihisa Godo, 2001).
} 
brings higher incomes (Goldin \& Katz, 2008, p. 16), because including females in the education system significantly enlarges the base of the skilled-labour force. Including females into the formal education system in the Republican era profoundly changed the way that people were employed in the labour market.

Females had long been missing from the government sector in Imperial China; hence, traditional education system, the foremost purpose of which was to select bureaucrats for the Imperial Court, had no reason to include women. Before the inception of the modern education system, almost all Chinese females were either home-educated or not formally educated at all. ${ }^{95}$ When these barriers were gradually removed after 1905 with the ending of the civil service exams, the rise of educational institutions for females began (Keenan, 1994, p. 3).

In terms of institutional setup, educational opportunities in China became more and more gender neutral (Huaxing Li, 1997, pp. 74-118; Lu, 1934, p. 42). In 1908, the Ministry of Education promulgated statutes which allowed for the establishment of normal schools and primary schools, specifically for girls (X. Wang, 1934) and in 1912 fully functional coeducational schools began to be built. From the available records, it appears that the share of female students attending senior primary school was 6.34 percent in 1923 and by 1930 the figure had doubled, reaching 15 percent (Huaxing Li, 1997, p. 729). More systematic records regarding the narrowing gender gap were documented for secondary schools, as displayed in Table 2.9. After 1916, the number of female students attending secondary school began to rise at an unanticipated pace such that the male/female student ratio fell from 79 in 1912 to 7 in 1929 and continued to fall, finally reaching 3 in 1946. With such an exceptionally rapid rise of female students in secondary education, the progress in primary education must have been even better, given that the graduation rate for male students in primary schools is normally higher than for female students.

Two patterns are worth highlighting here. First, the private sector contributed more in promoting equal gender education opportunities. The pioneers in educating women in

\footnotetext{
${ }^{95}$ Not all women were illiterate, of course, least of all those from gentry families. Such women would perhaps have had the chance to receive home education in Chinese literature and female ethics. However, in traditional China even this type of training was not available for girls in the lower social classes.
} 
China were Western missionaries ( $\mathrm{Lu}, 1934) .{ }^{96}$ A great number of missionary schools exclusively for girls were opened in quick succession in Beijing, Tianjin and Shanghai. Another important force was the rising number of domestic private girls' schools. By 1907, 428 girls' schools had been established of which more than half were private. Furthermore, such a respectable achievement was largely thanks to the spread of normal schools. ${ }^{97}$ Since the cost of receiving normal education was substantially less than that of general education and also since it guaranteed job opportunities after graduation, one of the most popular career choices for 'new women' through the first half of the $20^{\text {th }}$ century was to become a teacher after attending a normal school. ${ }^{98}$

Table 2.7: Male/Female student ratio in secondary schools (1912-1946)

\begin{tabular}{c|cccc}
\hline \multirow{2}{*}{ Year } & \multicolumn{2}{|c}{ Female students } & \multicolumn{2}{c}{ Male students } \\
\cline { 2 - 5 } & number & Percentage $(\%)$ & number & Percentage $(\%)$ \\
\hline 1912 & 677 & 0.01 & 51423 & 0.99 \\
1913 & 470 & 0.01 & 57510 & 0.99 \\
1914 & 956 & 0.01 & 66298 & 0.99 \\
1915 & 948 & 0.01 & 68822 & 0.99 \\
1916 & 724 & 0.01 & 60200 & 0.99 \\
1922 & 3249 & 0.03 & 100136 & 0.97 \\
1929 & 33073 & 0.13 & 215595 & 0.87 \\
1930 & 59939 & 0.15 & 337009 & 0.85 \\
1933 & 73667 & 0.18 & 342281 & 0.82 \\
1946 & 379087 & 0.26 & 1106060 & 0.75 \\
\hline \hline
\end{tabular}

*Source: (Yang, 1934, p. 194)

\section{Funding modern schools}

Given the fact that both the Qing and Republican regimes faced high fiscal pressure, how did these financially needy governments generate sufficient revenue to support education? To answer this question, this section first outlines the Chinese fiscal system

\footnotetext{
${ }^{96}$ In 1844, Miss Aldersey established the first mission schools specifically for girls in Ningbo.

97 The proportion of females in secondary schools did not exceed $4 \%$ before 1930, but the girls accounted for about $18 \%$ of normal school students (equivalent to secondary school) (Tao, 1923, p. 4).

${ }^{98}$ To attract more students, those who enrolled in normal schools were exempt from paying tuition fees, while their cost of living was also covered by public funding; in recompense, after graduation, they had to serve at least three years in a local primary school (Huaxing Li, 1997, pp. 512-513).
} 
before disclosing how tax revenues were generated at each level of government to support the development of modern schooling.

\subsection{Weak fiscal capacity and the implicit fiscal relationship in China}

Understanding the fiscal system is a serious challenge, because the financial structure of government as a whole through this period is difficult to trace. A detailed study of the evolution of the fiscal system is beyond the scope of this thesis, but some brief remarks about its basic features is more than necessary to understand how the public schools were funded. In short, from the late Qing to the early Republican eras, China's political authorities remained unable to gain control over substantial financial resources.

According to Confucian ideals of statecraft, the state intended to impose only a very limited economic burden on it population (P. Kuhn \& Jones, 1978). In addition, owing to high agency cost and the fear of exacerbating bureaucratic expropriation, Imperial China, as many scholars emphasise, had long maintained an extremely low level of taxation (Brandt et al., 2014; K. G. Deng, 2011, pp. 16-18; Sng \& Moriguchi, 2014). More importantly, the weak fiscal capacity of the state continued from the Qing and the whole Republican eras before 1937, the time period under discussion (T. Rawski, 1989, pp. 31-32).

The most striking feature of central-local fiscal relations during the Qing and early Republican era was the absence of a clear separation of sources of revenue between different levels of the administration and the 'communist' attitude to finance between various governments in China(C. S. Li, 1922, pp. 59-60). Local government functioned as a state agency for collecting tax revenues on behalf of the central state; apart from a minimal amount retained to support basic government operations, most of the tax revenue was remitted to the provincial level and then to central government (Marianne, 1985; D. Zelin, 1984, pp. 26-62). Such implicit regulation attracted heated contention over the vertical division of tax revenues. There were many attempts to streamline the tax division among different tiers of government after the late Qing. ${ }^{99}$ Beginning with

\footnotetext{
${ }^{99}$ In 1913, the Ministry of Finance drafted a revenue separation bill to be enacted by the first parliament of the Republic of China; however, such an attempt was disrupted by the unexpected seizing of power from Yuan Shih-Kai and the dissolution of parliament. Even though such a draft never became a law in
} 
the fiscal reform in 1909 and through successive legislations, the government did specify distinct sources for central government and provincial government revenues. ${ }^{100}$ However, the source of revenue for county and sub-county government remained unclear (Duara, 1988, p. 66; C. S. Li, 1922, pp. 701-791).

Because the division of tax revenues was already far from clear on paper, the challenge was multiplied in reality. Before 1937, land tax was the chief source of revenue for the government (S. Liu, 1935; Shaw, 1926, p. 173). The basic land tax was shared by the central state and provincial government. ${ }^{101}$ In addition, the central government enjoyed other stable tax sources, such as maritime customs duties and salt taxes (Sheridan, 1977, p. 199); while provincial government tightly controlled Likin, which constituted one of the most lucrative sources of revenue for the provincial treasury(Yi Xu, 2009). ${ }^{102}$ Last, county government possessed minimum de jure power over tax revenues, largely relying on the levy of prolific surtax through the tax collection process. ${ }^{103}$ Thereby, the collection of surtaxes and commercial taxes by county and sub-county governments for local purposes, in our case spending on local education, became more and more prevalent during the Republican period (Chauncey, 1992; C. S. Li, 1922; Remick, 2004, pp. 33-35).

\subsection{Educational Finance}

As regards educational finance in particular, the state set out the lowest permissible standard of educational development for local authorities; local educational officers had

the latter Republican era, a wave of regulations were issued to compile budgets for different levels of government (C. S. Li, 1922, pp. 75-77).

${ }^{100}$ Under the Beiyang government, several edicts were issued on the separation of tax revenues between central and provincial government. Accordingly, land tax, salt lax, maritime custom duties, inland custom duties, tea tax, business license tax, etc. yielded revenues under the National treasury; while surtaxes on the land tax, trade tax, livestock tax, rental duties and so on belonged to the provincial treasury $(\mathrm{C}$. S. Li, 1922).

101 The sharing ratio between central and provincial government was far from clear, and the real figure largely depended on the circumstances.

102 The Likin (厘金), was a form of internal tariff, which was first introduced as a means of financing the locally armies recruited to suppress the Taiping Rebellion. It then constituted one of the most important sources of revenue for provincial government. Likin became a major tax item from 1860 and was especially lucrative in such economically advanced provinces as Jiangsu. It remained widespread and was abolished only in 1931(Yi Xu, 2009).

${ }^{103}$ In theory, the county government was only attached to the provincial government, and therefore had little fiscal capacity. However, the collection procedure was carried out by the county governments; therefore, they could easily return the base land tax to the province, but levy surcharges for their own use through the same process. 
discretion over decisions to provide more than the minimum. Unfortunately, both the Qing Court and the Republican government failed to offer clear guidance on how revenues were to be generated to achieve the set goals. ${ }^{104}$

\section{Central level}

At the central level, the National Board of Education depended mainly on tax revenues that went to the National Treasury. However, the lack of any remittance from provincial powers, the enormous burden of paying for war indemnities and the primacy of military spending in government budgets meant that the central state experienced severe fiscal difficulties. The share in government expenditure taken by the educational budget to support tertiary schooling was a small, never exceeding 4 percent of the total.

Table 2.8: Education and military expenditure in central government expenditure

\begin{tabular}{|c|c|c|c|c|c|c|c|c|c|c|}
\hline Year & 1913 & 1916 & 1919 & 1925 & 1930 & 1935 & 1937 & 1940 & 1943 & 1945 \\
\hline Education & 1.08 & 1.06 & 1.32 & 1.22 & 2.04 & 3.7 & 1.71 & 2.19 & 2 & 1.84 \\
\hline Military & 26.9 & 31.6 & 43.8 & 46.9 & 45.5 & 34.9 & 66 & 72.1 & 67.8 & 84.9 \\
\hline
\end{tabular}

*Source: The China Yearbook for the above years

\section{Provincial level}

China during the first half of the $20^{\text {th }}$ century collapsed into a state of political and military tension between a number of provincial military cliques. Consequently, the central problem of educational funding encountered at provincial levels was also due to high military expenditure. The figure varied significantly across provinces, but almost all provincial governments considered their priority to be the certainty of enough to spend on warfare, leaving little funding for other public goods, including uninterrupted investment in schooling. ${ }^{105}$

\footnotetext{
${ }^{104}$ For instance, the Qing Ministry of Education (xиеbu) set liberal standards for local authorities in 1904: one tertiary school in each provincial capital, one secondary school in each prefecture, and one higher primary school in each county (Yang, 1934). Under the Republicans, the scenario remained similar, even though the responsibility for each tier of government became more distinctly defined by newly-issued statutes. The state specified that the responsibility for constructing higher primary schools was up to the county government, while the lower primary schools were the responsibility of townships and villages (Yang, 1934). Secondary education continued to come under the provincial government and tertiary education under the central government.

${ }^{105}$ Cases of defalcation for military purposes were commonly seen. For instance, in 1924, the provincial government of Zhili controlled by Wu Peifu, misappropriated educational funds for the purpose of financing the second Zhili-Fengtian war, which directly led to a large number of schools being abandoned
} 
Unfortunately, annual information on provincial budgets is not available. For 1933, however, we have rich data documenting provincial educational expenditure. On average, 12.44 percent of the income of the provincial budget was used on education, which was higher than the proportion used by the central government; whereas the regional dispersion was large. Anhui Province spent 24.15 percent of its revenues on supporting educational development, while for some remote provinces, such as Qinghai and Guizhou, the shares were only 4.97 percent and 6.93 percent respectively (Quanguo Jiaoyu Jingfei Tongji 1932-1933 (The national educaitonal finance 19321933) 1937, p. 21). As suggested by the educational regulations, provincial governments mainly undertook the responsibility for secondary education, which occupied 47.2 percent of provincial budgets; while 20 percent was allocated to tertiary schooling and only 13.6 percent for primary schooling (Quanguo Jiaoyu Jingfei Tongji 1932-1933 (The national educaitonal finance 1932-1933) 1937, p. 23).

\section{Local level106}

As noted in the Education Act 1904, 1912 and the later revised clause of the Primary Education Act 1915, it is clear that the county and sub-county governments were supposed to collect enough funds to support primary education (F. Wang, 1994, pp. 441-517). However, both county government and sub-county communities were in low financial circumstances, as discussed above. Their budgets could not be met solely through public efforts and relied on a combination of funds from various sources: local taxes, rents from public lands, donations from the local wealthy elite, as well as parental contributions (tuition fees). Accordingly, the main revenue for county budgets came from surcharges on tax, land tax in particular(S. Liu, 1935, pp. 159-194).

In 1933, based on education reports for 7 provinces, we find 74.9 percent of the eudcation revenues at county level coming from surcharges on $\operatorname{tax}^{107}$; surchages on land

and a 500,000 drop in school enrolments (Huaxing Li, 1997, p. 539). A similar story is observed in Fujian province, where due to grave arrears of educational funding from the provincial budget, school teachers went on long strikes. Similar scenarios were seen in many provinces, such as Hunan, Zhejiang and Jiangsu.

${ }^{106}$ A more detailed analysis on local level educational finance is made in Chapter 4 , focusing on the rise of primary schooling.

107 The dmminant surcharges were on land tax. When the new Republican regime was established, land tax was composed only the three charges that made up the base tax of land tax (zhengliang). However, 
tax alone accounted for 47.25 percent of the revenue (Quanguo Jiaoyu Jingfei Tongji 1932-1933 (The national educaitonal finance 1932-1933) 1937, p. 108). Other compelling evidence lies in more than 400 county government balance sheets on educational finance in the 1930s that have been collected in the present study. As Table 2.4 shows, the county budget for primary education came at this time from two main sources, namely, tax surcharges (land tax as a whole) and revenues generated from endowed school land.

Table 2.9: Sources of the revenue for primary education (county)

\begin{tabular}{rcccccc}
\hline & All & Hubei & Shandong & Henan & Zhili & Jiangsu \\
\hline Various surcharges & $\mathbf{6 3 . 7}$ & 41.49 & 70.4 & 76.7 & 59.62 & 70.29 \\
surtax on land tax & $\mathbf{4 0 . 6 1}$ & 21.94 & 62.3 & 51.8 & 26.43 & -- \\
\hline \hline
\end{tabular}

*Note:

In the 1930s, a number of provinces published government reports on education enclosing statistics at county level, but the informativeness of these reports differs significantly across provinces. Of the provincial reports that I collected from archive, ${ }^{108}$ five carefully document the source and composition of educational income. The above table presents information for the provinces of Hubei, Zhili, Jiangsu, Shandong and Henan, 423 counties in total.

*Sources:

(Quanguo Jiaoyu Jingfei Tongji 1932-1933 (The national educaitonal finance 1932-1933) 1937, pp. 105-109)

(Shandongsheng Gexian Difang shibaniandu Jiaoyu Jingfei Suiruiyilanbiao (County balance sheets for education in Shangdong Province across counties, 1929) 1930)

(Hunansheng Zuijin Geniandu Shengshixianqu Jiaoyu Jingfei Diaocha Tongji (The county-level reports on education finance of Hunan Province), 1933)

(Hebeisheng Gexian Putong Jiaoyu Gailan (The county-level reports for general edcuation in Hebei province), 1928)

(Henan jiaoyu yianjian (The Education Yearbook of Henan province), 1930; Jiangsu Jiaoyu Gailan

(The education reports for Jiangsu province), 1933)

The fiscal burden of building up modern primary schools was not only laid upon county governments, but also drained the resources of sub-county communities. These grassroots governing entities bore a double burden: paying new taxes to fund the new

after warlord politics developed, surcharges were added to land tax and collected for the county budget. In most cases, the surcharges on land tax even exceeded the base tax. The best illustration comes from the infamous Sichuan province. We observe that in some counties, such as Wan County, surcharges were 30 times higher than the basic land tax (Sun, 1935, pp. 213-217).

108 To my knowledge, 11 provinces published similar education reports in 1930s, in response to a request from central government. 
governmental schools located in the county seat; and bearing the costs of establishing and managing the modest lower-primary schools that at the time outnumbered every other kind of educational institution in China teaching lower-primary age children (VanderVen, 2005, pp. 204-235). In the absence of any formal taxing authority for townships and village governments, rural communities had to find the money wherever they could. These local primary schools relied on a combination of sources, including community funds, individual donations and tuition fees. This practice appears to have been common across early- $20^{\text {th }}$ century China.

\section{Concluding Remarks}

The discontinuation of the civil service examination in 1905 officially marked the advent of the modern schooling system in China. The new education model contained three main features. First, the new education system intended to make schooling extensively available to the whole population; and for this reason the system was largely public. The state was more supportive towards primary education and the private sector was allowed to play a greater role in providing higher level, or more elite education. Second, the education content was radically transformed, from focusing only on the Confucian classics to a new and vigorous curriculum of Western subjects; in the same vein, the new curriculum also emphasised an ideological campaign aimed at the whole population. Last, this new education system was crafted as a highly decentralised structure, the degree of decentralisation being highest at primary level.

This new education system was modern, public and expensive; as a result, the first and most important task was to raise funds for the increasing number of modern schools. With a weak fiscal capacity and vaguely regulated fiscal relationships, each level of government showed its prowess and grabbed whatever it could lay its hands on; in the melee, not only were legitimate tax revenues mobilised, but also a pool of countless surtaxes, commercial fees, collectively owned endowments and private contributions to pay for the new education system.

Along these main features, a number of outstanding improvements took place in subsequent decades, thanks to this educational movement. The four major areas of 
progress were: (i) the shift from informal schooling to formal education; (ii) the absolute dominance of public schools in the education sector; (iii) significant improvement in curriculum design; and (iv) equal educational opportunities for both genders. 


\section{Chapter 3 : Long-term Trends in Schooling: Measuring educational development}

We have seen in the preceding discussion that a brand new education system was set up at the turn of $20^{\text {th }}$ century. In order to assess the spread of modern schooling, the quantitative dimensions of this educational development will be presented in this chapter. Long-term estimates of China's educational growth in the first half of the $20^{\text {th }}$ century, in terms either of flow variables or stock measures, are extremely rare. This paucity of empirical analyses can mainly be attributed to the lack of census data. Most of the existing literature focuses on the post-reform period, leaving us with very little knowledge about how much education actually grew before 1949. In this chapter, on the basis of various measurements, we try to plot a general trajectory of the educational growth of China from the dawn of the $20^{\text {th }}$ century onward.

Human capital was created through both formal and informal education; therefore, indicators which try to capture the education received by people are also often treated as proxies for human capital (Wößmann, 2000). Scholars have explored a variety of indicators to quantify the level of human capital across regions and over time. In the extensive literature are three widely used categories of measurement, namely, literacy rates (or numeracy rates), gross enrolment ratios for different schooling levels, and educational attainment (or average years of schooling). The former two refer to flows of investment in education, while the last captures the stock of human capital.

The global view holds that there are huge differences in educational development across countries; whether measured by enrolment rate, educational attainment, or quality of schooling. By the early 20th century, some nations, led by the US and Prussia, had already achieved universal primary schooling, while other nations, such as China, had only begun to establish a first national education system. The 'Great Divergence' in terms of education has been so huge that, by 1860, the primary enrolment rates in the US had reached 70 percent (Goldin, 2015) This figure went on rising and hit the figure of 90.6 percent in 1880 (Lindert, 2004a, p. 91), a level realised by China only after 110 years - around the 1990s. 
This chapter aims to address two questions: i). How quickly and widely did the modern education system spread? ii) Was there a steady increase in human capital? Since no perfect indicator exists, this chapter starts with an overview of the changing trend in literacy rates, providing a basic picture of the education level through the first half of the $20^{\text {th }}$ century. Then estimates of gross enrolment ratios for each level of education are presented, to directly reflect the expansion of formal schooling. The last section turns to a widely used educational stock indicator - average years of schooling - to further demonstrate the human capital development in China. Finally, to put China into perspective, we draw international comparisons based on each indicator.

\section{Measuring Literacy Rates in early $20^{\text {th }}$ century China}

The literacy rate measures the proportion of population with the ability to read and write. ${ }^{109}$ This indicator captures the very first part of the investment made in education and neglects further investment, which could generate higher levels of cognitive ability, skills and knowledge beyond basic literacy; consequently, it reflects only a small component of human capital, providing no more than a lower benchmark for measuring overall educational achievement. Nonetheless, in pre-modern societies where a very limited number of people receive education, the literacy rate offers a crucial clue to the spread of basic education across the population; at the same time, for the sake of simplicity and data availability, the literacy rate tends to be observable well before other sophisticated measurements appear. In the same vein we could count numeracy rates, which reflect people's ability to apply simple numerical concepts, as an alternative proxy for the basic level of human capital; many studies suggest that numeracy rates are highly correlated with literacy rates (A'Hearn, Baten, \& Crayen, 2009).

Through the early $20^{\text {th }}$ century, China, with no national census data, provides the main only information on its literacy rates from a number of social surveys, conducted as part

\footnotetext{
${ }^{109}$ Ways of defining a person as literate or not are also ambiguous. Quoted in UNESCO, Gray offers a definition of a literate person as one "who has acquired the knowledge and skills in reading and writing, which enable him to engage effectively in all those activities in which literacy is normally assumed in his culture or group' (Gray, 1957). In practice, for many historical studies on pre-modern societies, the people who can sign their names can be easily distinguished as the literate ones.
} 
of the rise of 'investigative modalities' in pursuit of a 'culture of fact' (Lam, 2011). ${ }^{110}$ In this section, we gather circumstantial evidence on the literacy rates in China between the late $19^{\text {th }}$ century and the first few decades of the $20^{\text {th }}$ century. Drawing on existing micro-level surveys and case studies, this section sketches a general picture of the changing trajectory of national literacy rates from the late $19^{\text {th }}$ century onward.

\section{Late Qing (1840-1911)}

As a starting point, it is critical to pin down Chinese literacy rates in the late Qing period as a benchmark. Many historical narratives suggest that Imperial China already possessed a highly literate population, but very few provide concrete evidence to support this claim. Based on Maritime Customs Reports, Perkins estimates that less than 50 percent of males over school age in 1880 s could be regarded as literate (D. H. Perkins, 1975, p. 4). Similarly, in her landmark book on education in the Qing dynasty, Rawski argues that basic education, mainly in an informal and traditional format, was under the rule of the Qing diffused nationwide, resulting in a high literacy rate. She points out that, even though the variation could be remarkably large across regions and between genders, a rough guess at the literacy rate during the late Qing might be 30 percent to 45 percent for males and 2 percent to 10 percent for females (E. Rawski, 1979, pp. 8-23).

If these figures are valid, then China had a very similar level of literacy rate to late Tokugawa Japan, where the rate for men was estimated at 40-50 percent, and for women 13-17 percent (Ohkawa \& Rosovsky, 1973, p. 8). This suggests that, before the $20^{\text {th }}$ century, in these terms China was comparable to Japan. ${ }^{111}$ However, the gap widened quickly after Japan's economic take-off under full-scale Westernization, with the Japanese literacy rate reaching 45 percent in 1890 (Luween \& Foldvari, 2008). If we bring European nations into the comparison, China's achievement in this area before the $20^{\text {th }}$ century is much less impressive. Most Western European nations and the USA experienced a remarkable rise in literacy as early as 1500; indeed, before 1900, probably 80 percent of Americans could be regarded as literate (the number stands at 90

\footnotetext{
${ }^{110}$ In social science, a foremost important methodology - the collection of empirical facts - came to China relatively late, only after the late $19^{\text {th }}$ century when China was exposed to Western culture as well as its academic environment.

111 The attempt to modernise the country following the Western model occurred in Japan in the 1860s, i.e. a few decades earlier than in China.
} 
percent if whites alone are included) (Black \& Sokoloff, 2006); and the ratios was 88 percent in Germany, 77 percent in the UK and 70 percent in France (Green, 1990, p. 33). Apparently, China, and all East Asia, lagged well behind the West in offering broad access to basic schooling.

In contrast to studies of literacy rates, Baten et al. find that given the low income level, the numeracy in Imperial China was intriguingly high (Morgan, Baten, Ma, \& Wang, 2009). According to the calculations of Morgan et al., from 1820 to 1920, numeracy among the Chinese was on a par with numeracy in the UK and France; moreover, it was much higher than that of India or Turkey. If we do not point fingers at the pragmatic bias age-heaping index, ${ }^{112}$ this finding demonstrates the possibility that basic education was already widespread in China before the advent of the modern schooling system.

In the same vein, some historians have documented the prevalence during the Qing dynasty of written communication of all kinds in hiring labour, renting property, spreading news and even in binding marriages, in remote rural societies as well as towns and cities (E. Rawski, 1979, pp. 9-13; M. Zelin, 1994). Such a high incidence of written contracts, advertisements and news indicates a large proportion of readers dating from the $18^{\text {th }}$ century.

\section{$\underline{\text { Republican Era (1911-1948) }}$}

Did the formation and the spread of modern education from the $20^{\text {th }}$ century onward in China actually raise the literacy rate? In his important book on China, Chien indicates that the literacy rate in the Republican era stood at 70 percent, which seems a considerable jump above the figure in the late $19^{\text {th }}$ century; unfortunately he offers no compelling explanation for this figure (Chien, 1950, p. 13). Between 1918 and 1919, Gamble and Burgess conducted an extensive survey in the city of Beijing; their results show that only 16 percent of its residents could not read. Adjusting for missing data, the literacy rate that they report corresponds to Chien's figure - about 70 percent literacy (Gamble \& Burgess, 1921, p. 507). This result is confirmed by John Buck’s study. Buck carried out one of the most comprehensive large-scale individual surveys in China

\footnotetext{
${ }^{112}$ Many critics have doubted whether the measure of the age-heaping index can be considered a good indicator of the numeracy rate. One possible explanation for the fact that the Chinese were less able to round up their age to the nearest 0 or 5 is a link to the tradition of the Chinese zodiac, which made it easier for the Chinese to remember their exact age.
} 
through the 1930s. Compared with every other researcher in this field, he presents exceptionally detailed records on Canton, one of the most important commercial urban areas and international trade centres in China throughout this period; the literacy rate in urban Canton that he reports is as high as 80-90 percent (Buck, 1937). Even though both studies focus on metropolitan areas only, these figures demonstrate a fairly high level of human capital in China, by any standard; more importantly, it indicates a pronounced increase in the literacy rate from the late $19^{\text {th }}$ century to the $1930 \mathrm{~s}$.

Exactly opposite evidence, however, can also be found in the existing literature. For instance, another important study by Gamble and Burgess, which was conducted in a model county of Zhili Province - Ting county - finds that in the 1930s only 20 percent of the population over six years old could be counted as literate. Breaking down this number, only about one third of males were literate, while 3 percent of females were able to read and write (Gamble, 1954, p. 185). Moreover, Buck studied regions far beyond Canton, and the results derived from pooling data for different regions together suggest that 45 percent of all males over 7 years of age had received some schooling, or could be considered literate. This scattered set of estimates shows no marked rise compared to the level of the literacy rate through the late Qing period. How should we interpret such different results for the same period? For both views to hold, the only plausible explanation is that there was a high level of regional dispersion in the literary rates across China at the time.

Instead of drawing evidence from contemporary social survey data, another way to measure the literacy rate for the first half of the $20^{\text {th }}$ century is to get the estimate for the following period, and then project the result backwards. The first population census after the Communist party came to power was conducted in 1953; unfortunately, it does not include information on literacy. The second was in 1964 and documents a literacy rate in China of 66 percent. Given that the massive campaign on 'eliminating illiteracy in rural China was undertaken in the 1950s', ${ }^{113}$ most scholars believe that the literacy

\footnotetext{
${ }^{113}$ Under the rule of Mao, a large-scale education movement was set in motion throughout the country to eliminate illiteracy. The efforts were not limited to schools, but went far beyond formal educational institutions - classes for adults as well as children, for males and also females were held inside and outside schools. Different formats for informal training schools, adult schools, short-term schools and part-time schools emerged to teach people basic reading and writing skills and impart some knowledge of the new regime. Almost the entire nation was involved in this mass education movement: government offices, factories, urban committees and villages all held different kinds of study sessions for their people
} 
rate soared dramatically between 1950 and 1960. This implies that literacy rate preceding 1949 would have been well below 66 percent.

In a nutshell, the scattered and circumstantial evidence make it difficult to provide any conclusive claim about the levels of literacy between the late $19^{\text {th }}$ century and the early $20^{\text {th }}$ century. But there are a few points we can be quite certain about; first, literacy increased after the late $19^{\text {th }}$ century. The proportion rose from less than 50 percent to close to two-thirds. Moreover, the regional gaps in literacy rates were noticeably wide, in particular the urban/rural differences. In some major urban centres, the literacy rates shot up, reaching so high a level that universal literacy, for men at least, came very close; whereas in remote and rural areas, literacy rates remained remarkably low just as they had in many pre-modern societies. Last but not least, as discussed in Chapter Two, the rising literacy in China from the $20^{\text {th }}$ century onward was largely attributed to the radical improvement of equalising educational opportunities for women.

\section{Measuring gross enrolment ratios for $20^{\text {th }}$ century China}

The most commonly seen and widely cited indicator for the quantity of formal schooling is the gross enrolment ratio. It estimates the share of students enrolled at a schooling level relative to the total population of similar age; it therefore explicitly reflects the schooling attainment of a population.

Gross enrolment ratio is defined by the UNESCO Institute for Statistics as enrolments at a given level of schooling divided by the population of the official age range associated with this level of education.

$$
e_{g}=\frac{E_{g}}{P_{g}}
$$

In Equation (3.1), Eg is the enrolment (the number of students enrolled) at schooling level $g$ and $P g$ is the total population of the age group that national regulations require to be enrolled at grade level $g$. It should be noted that, according to the formula, the gross enrolment ratio is calculated by taking all the people enrolled at a certain level of education nominated by the population who belong to this age cohort. Given the

(T. H.-e. Chen, 1974, pp. 18-51). If we do not cite figures on the quality of the education, at least the regime can be credited with the achievement of raising the literacy rate in China through this period. 
existence of under- and over-aged students, gross enrolment ratios may possibly exceed 100 percent.

One particular strength of gross enrolment ratios as an indicator lies in their accessibility and availability. Enrolment records are usually abundant in most societies, because international organisations such as the World Bank, national statistical bureaus for any given country and local statistical departments across the globe collect annual series for political purposes. ${ }^{114}$ Moreover, when collecting figures on enrolment, education reports often enclose relevant data on the number of schoolhouses, teaching staff and educational expenditure. This rich information allows scholars to measure the size of the formal schooling sector from different standpoints. Another reason why the gross enrolment ratio is exceptionally popular in academic studies is that enrolment data constitutes the starting point for almost every other more demanding estimate of educational stock, such as average years of schooling, which can be derived from the series of long-term enrolment ratios. Finally, as the most standardised and widely used indicators for education quantity, gross enrolment ratios have been estimated in many studies across the world, which facilitates global comparisons of educational progress.

Notwithstanding all the virtues of enrolment ratios as a measure of educational attainment, they have several possible defects that may cause problems in measuring Chinese educational progress. First, in common with most studies targeting developing countries, the central challenge lies in 'the population risk'. In earlier historical periods, as well as for developing countries, a figure for the total population is rare, let alone a valid school-age cohort population (Benavot \& Riddle, 1988). The imperfect demographic data documenting a detailed breakdown by age group prevents us from estimating the school-age population precisely. The tremendous challenge is further multiplied when the eligible age group for each level of education changes over time, because of changes in official regulations regarding the entrance age and length of any given level of education. ${ }^{115}$ Furthermore, besides the main concern over 'the risk population', there are other reasons to question the quality of historical enrolment

\footnotetext{
114 The enrolment ratio is very sensitive to exogenous factors, such as changes in the educational system or the fiscal budget; therefore, governments tend to document information on enrolment.

${ }^{115}$ For details on changes of length and the entry age for each level of education over time, please refer to Table 2.4.: structure of education, in Chapter Two.
} 
records documented in government reports. Some of these problems are minor, while others are more substantial. Enrolment figures are not necessarily equal to attendance, and according to historical accounts in Europe through the comparable period, attendance rates tend to be 15-30 percent lower than the corresponding enrolment rates (Benavot \& Riddle, 1988). This problem could be quite severe in China during the first half of the $20^{\text {th }}$ century, in particular during the agricultural harvest season. ${ }^{116}$ The accuracy of 'bottom-up' enrolment figures is doubtful. For instance, the universal truth about government reports is that local government tends to over-report performance, in order to demonstrate its good government and to attract more subsidies. In the Chinese context from 1900 to the 1930s, this kind of bias could be relatively small in its context, given the weak supervision and limited subsidies from the upper tier of government.

\subsection{Expansion of primary schooling}

China was far from achieving universal literacy in the early $20^{\text {th }}$ century. The rise of primary education therefore held exceptional importance throughout this period. This section estimates how much primary education progressed through the first half of the $20^{\text {th }}$ century, for both the modern and traditional tracks of 'primary schooling'.

\subsubsection{Modern track of primary schooling}

Before 1900, the only areas of the world where most of the school-age children had access to primary education were the United States, Canada, Prussia and Scandinavia. Universal primary schooling was eventually achieved in other Western European nations and Japan after the beginning of the $20^{\text {th }}$ century (Benavot \& Riddle, 1988; Easterlin, 1981; Lindert, 2004a; Mitch, 2013). Compared to the extensive literature on the developed world, studies estimating Chinese historical educational enrolment ratios are scarce, as few resources have survived the ravages of time. Benavot provides three aggregate estimates; the primary enrolment ratio for China in the 1920s was 4.5 percent

\footnotetext{
116 The government had detailed regulations on term lengths and attendance times. For instance, $1^{\text {st }}$ August was the start of every academic year, which was broken up into three terms. The summer vacation lasted between 30 and 50 days. The winter holiday and spring breaks were regulated at 7 days each, and should not exceed 14 days. For rural primary schools, according to social norms, extra breaks could be granted in autumn through the harvest season (F. Wang, 1994, pp. 63-64). However, the attendance figures in practice must be unimaginable. Concerning the highly agrarian nature of China's economy, attendance rates would probably have dropped sharply during busy seasons for farming, such as autumn harvest-times.
} 
and the figure rose to 10.3 percent and 12.4 percent for the $1930 \mathrm{~s}$ and $1940 \mathrm{~s}$ respectively (Benavot \& Riddle, 1988). Recently, Chaudhary et al. have reported that in 1900 only 4 percent of the Chinese school-age cohort was enrolled in modern primary schools, which includes only the national enrolment figure from the first education yearbook published in 1907 and simply applies the figure of $15 \%$ of the population as the school-age group (Chaudhary, Musacchio, Nafziger, \& Yan, 2012) . ${ }^{117}$

Figure 3.1: Gross enrolment rates in modern primary education, 1900-2005

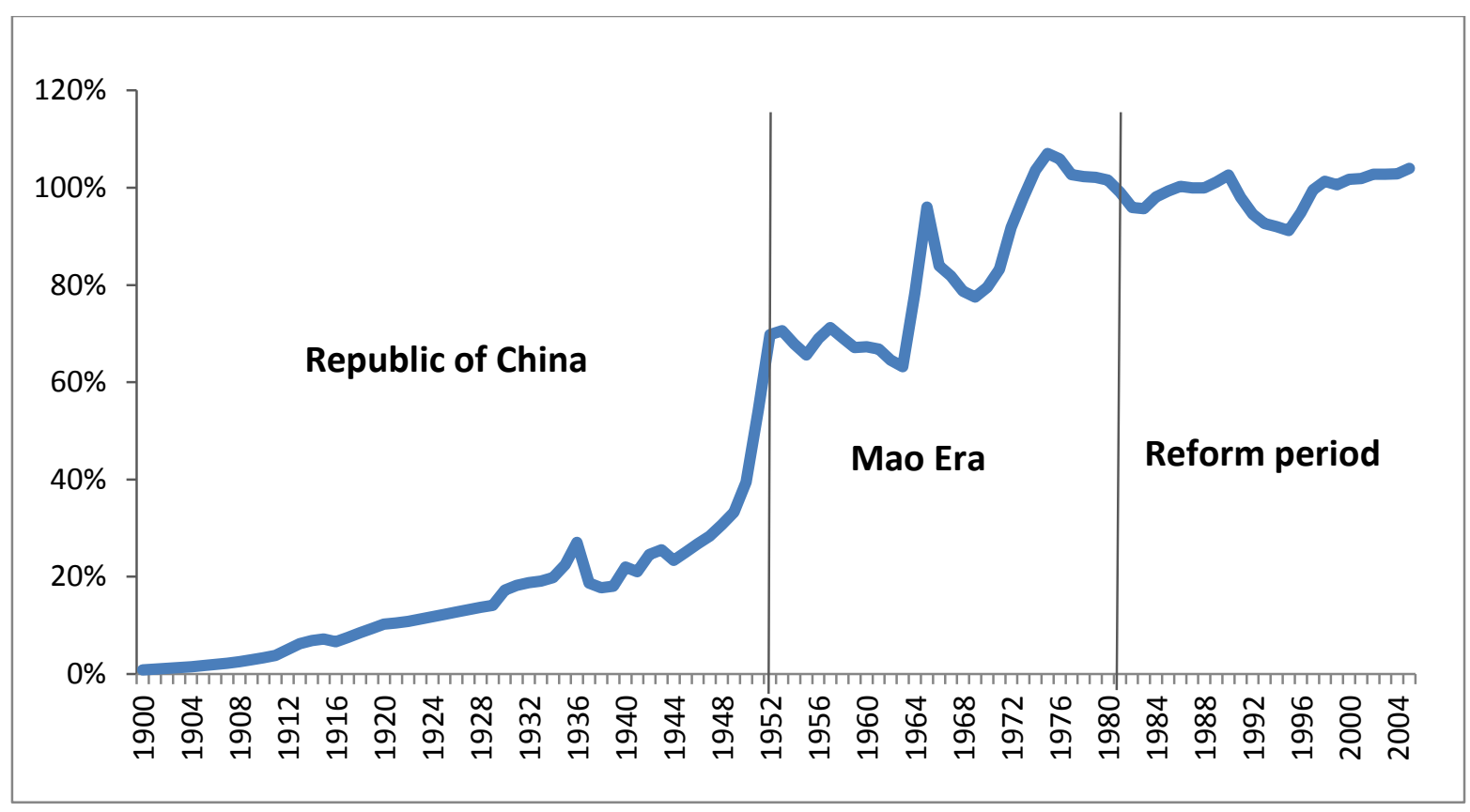

*Source: i. enrolment data: Chinese Yearbooks on Education in corresponding years.

ii. Population and age structure: (Hou, 2001)

In 1878, the first Chinese primary school in the modern sense was established in Shanghai (Yang, 1934, p. 421); ${ }^{118}$ from this date China's modern primary schools began to flourish. The most drastic development on the journey towards universal primary education took place in 1915, when compulsory education was legislated, oblige children to attend at least 4 years of lower primary schooling (F. Wang, 1994, pp. 460-468). Even though such a policy was too ambitious at the time to achieve, modern primary schooling spread more quickly afterwards. The number of primary schools was only 173 in 1902 but it grew by 1850-fold in the following few decades, to 320086 in

117 This chapter shows a slightly lower primary enrolment ratio than that of Chaudhary et al. (Chaudhary et al., 2012); because they apply $15 \%$ of the population as the school-age group in China; while we apply both age-groups, 6-11 and 5-14. as our population nominators.

${ }^{118}$ In 1878, China's first modern primary school (Zhengmeng School) was established in Shanghai by Huanlun Zhang. 
1936, the eve of the breakout of Japan's full-scale invasion of China, ${ }^{119}$ illustrating the marked expansion of primary education over the early $20^{\text {th }}$ century.

Figure 3.1 displays the changing trends of primary enrolment ratios throughout the $20^{\text {th }}$ century and, according to official regulations regarding the pupil's school-age group, we employ 6-11 as the eligible age range for primary education. Data on primary enrolment ratios in China through the first half of the $20^{\text {th }}$ century, together with comparable data for the United States, Japan ${ }^{120}$ and India are reported in Table 3.1. One point that should needs to be stressed here is that, unlike the data presented in Figure 3.1, to facilitate cross-country comparison, a broader school-age band (5-14) is adopted in this table; ${ }^{121}$ the numbers set out in Table 3.1, should therefore be regarded as a lower bound for the accrued enrolment ratio in China.

According to Figure 3.1, at the beginning of the $20^{\text {th }}$ century, the primary enrolment ratios stood at about 1 percent ( 2 percent), ${ }^{122}$ leaving a wide gap between China and its counterparts. ${ }^{123}$ But it rose rapidly in the proceeding decades and hit 17 (27 percent) $)^{124}$ on the eve of the Japanese invasion in 1937; the expansion of its primary education in the three decades was so successful that its primary enrolment ratio outstripped India's (11 percent) and at least rivalled Brazil's (21 percent) (Lindert, 2004a, pp. 91-93) .

Unfortunately, the noticeable rise of primary schooling was interrupted by the catastrophic upheaval of the 1937 invasion, which was then followed by a 4-year civil war between the Communist Party and the Nationalist Party. Illustrated in Figure 2.1,

\footnotetext{
119 The national figures on enrolment after 1937 are highly doubtful. Since the National Government kept losing control over territories to Japan, they were unlikely to receive educational reports with the same geographic coverage as had been sent before the war. To avoid the complexity relating to data quality caused by the major warfare, even though we present data series covering the wartime period, this study focuses mostly on the years before 1937.

${ }^{120}$ Between the $19^{\text {th }}$ and early $20^{\text {th }}$ centuries, all other Asian nations were under Western regimes, most of which promoted a modern educational system. Only three nations in Asia were not completely colonised: Japan, Thailand and China.

121 Since regulations regarding the school-age population differed across countries, to make the comparison easier, many studies in calculating primary enrolment ratios adopt the age range of 5-14 as their school-age population nominator.

122 The figures outside parentheses are the ones calculated by applying the 5-14 age cohort as the schoolage population for primary schooling; whereas the figures in parentheses are the ones reached by applying 6-11 as the age group for primary schooling.

${ }^{123}$ China's unusually low enrolment ratio in primary schooling is caused by the fact that the modern formal education system in China was established much later than in other developing countries. The process started only at the turn of the $20^{\text {th }}$ century in China, whereas for the nations colonised by the West, the modern education system was established by government in the early $19^{\text {th }}$ century.

${ }^{124}$ As noted in footnote 122
} 
the enrolment ratio dropped sharply, falling to 12 percent (19 percent) ${ }^{125}$ after 1937 and the ratio recovered slowly after this. The level before the war was not regained until 1947.

Table 3.1: Modern Primary Enrolment Ratios, per 1000 population (5-14)

\begin{tabular}{cc|cccc}
\hline Year & China & Year & India & Japan & $\begin{array}{c}\text { United } \\
\text { States }\end{array}$ \\
\hline 1907 & 12 & 1890 & 44 & 370 & 971 \\
1912 & 33 & 1900 & 47 & 507 & 939 \\
1915 & 47 & 1910 & 65 & 599 & 975 \\
1922 & 72 & 1920 & 80 & 602 & 924 \\
1930 & 119 & 1930 & 113 & 609 & 921 \\
1949 & 214 & 1950 & & & \\
\hline
\end{tabular}

*Source:

i.For China, the enrolment data comes from Yearbooks on Education in corresponding years; and population and age structure is from (Hou, 2001).

ii: For the United States, India and Japan come from ((Lindert, 2004a, pp. 91-93)).

*Note:

For primary schooling, the schooling age population refers to children are between 5 and 14 years old.

Even though not the focus of this study, it is worthwhile to briefly outline the general trajectory of primary schooling after the founding of the People's Republic of China in 1949. As illustrated in Figure 3.1, a huge jump occurred in the primary enrolment ratio in the early days of Mao's leadership. This remarkable achievement can in part be attributed to the efforts of the new Communist government in providing equal educational opportunities for all social classes, in accordance with the Communist Party's political ideology (T. H.-e. Chen, 1974, pp. 59-84). At the same time, this sudden increase in the enrolment ratio can also be regarded as a bounce back after the abnormally low war-time level. The rising trend did not last for long; instead, primary enrolment ratios went on to experience several significant fluctuations. The first occurred between 1952 and 1962, covering the period of the Great Leap Forward; while the second and more extensive interruption took place from 1965 to 1968 , during the

${ }^{125}$ As noted in footnote 122. 
early stages of the infamous Cultural Revolution. ${ }^{126}$ The primary enrolment ratio bounced back rapidly and reached its peak of 107 percent in 1975, reflecting a success in achieving universal primary education in China after almost one century of endeavour.

In conclusion, modern primary schooling in China was scarce at the turn of the $20^{\text {th }}$ century. It started to converge with its counterparts in the developing world through the first half of the $20^{\text {th }}$ century. Despite a handful of disruptions between the 1940 s and the 1970s, the primary schooling expansion achieved its aims, with enrolment rising to 100 percent by the 1980 s.

\subsubsection{Alternative educational tracks: enrolment in Sishu (私塾))}

The low primary enrolment ratios at the very beginning of the $20^{\text {th }}$ century can be partly explained by the fact that the educational transformation took time to be fully implemented. Despite traditional education's being officially discontinued in 1905, a large number of traditional-style primary schools did not disappear overnight but persisted as substitutes for modern primary schools throughout the early $20^{\text {th }}$ century. As discussed in Chapter Two, under the traditional schooling system, the Imperial State rarely provided the masses with schooling at a lower level; consequently, the educational institutes serving the function of spreading basic schooling, which could be referred to as the traditional style primary schools, were collectively called Sishu (P. Deng, 1997, pp. 6-8; E. Rawski, 1985, pp. 24-33). ${ }^{127}$ These traditional primary schools were privately funded, informal and small-scale. The central focus of this study is on the modern (formal) education system; however, the prevailing presence of Sishu cannot be completely neglected. According to Tao, the actual enrolment ratio for primary

\footnotetext{
${ }^{126}$ Contrary to what might have been anticipated, the primary schooling enrolment ratios managed to keep their increasing trend after 1968 through the whole late Mao period; unlike higher education, most primary schools continued to operate during the Cultural Revolution. By the 1980s, almost every commune had its own primary school; however, the quality of education was considerably compromised. In schools, academic performance was no longer valued highly, while political loyalty and conformity were highly emphasised, and became the dominating criteria for judging a student's performance.

${ }^{127}$ Sishu (私塾): the sishu was purely private, as the name indicates ( $\mathrm{Si}$ means privately owned in Chinese); and almost all school-age children in traditional China were educated in them. Sishu were conveniently divided into 3 general types: Family Sishu; lineage or village Sishu and privately established schools. This absence of Sishu from the bureaucratic dictionary means that they have no statistical history; hence, we have no idea of the national level of enrolment ratios for traditional primary schooling in Imperial China.
} 
education in China should at least be doubled, if Sishu are taken into account (Tao, 1923, p. 6). In a nutshell, calculating the enrolment ratios for Sishu and sketching the changes in them helps us understand the level of modern primary education and how it was attained.

Under the traditional system, in general, there were two types of sishu separated by their curriculum. ${ }^{128}$ Children went to junior Sishu to learn to read, write and do basic arithmetic so as to cope with everyday life; ${ }^{129}$ after about 4 years of basic studies, students could further enrol in senior Sishu to learn the Confucian classics in preparation for the Civil Service examination (E. Rawski, 1985, p. 31). After the abolition of the exam in 1905, senior Sishu eventually faded away, but junior Sishu continued to run in villages, small towns and also big cities, as an alternative to modernstyle primary schools. ${ }^{130}$ After the collapse of the Qing dynasty, to address the persistent popularity of Sishu across the country, a series of regulations was launched calling for their improvement to a standard comparable with the modern primary schools (Borthwick, 1983, p. 81) ${ }^{131}$. All these reform programmes saw very limited achievement, but then the state changed its attitude and banned the legitimacy of Sishu altogether after 1928 despite their activities (Liao, 1936; B. Zhang \& Qin, 2001, pp. 1417). Sishu continued to play a big role in the basic education of the population throughout the first half of the $20^{\text {th }}$ century. ${ }^{132}$

\footnotetext{
${ }^{128}$ Sishu varied a great deal from every standpoint (E. Rawski, 1979, pp. 44-53), the detailed elaboration of which is outside the scope of this study. Here we provide only a very general classification.

${ }^{129}$ Almost of all Sishu had very similar and standardized curriculum,. They used Thousand Character Text (千字经), Hundred Surnames (百家姓), and Three Character Classics（弟子规） as text book to train children to read and write. These texts at least constitute 1500 different characters, and also encoded with classical Confucius values(B. A. Elman, 2013, p. 47).

${ }^{130}$ Another important reason why the Sishu persisted through the early $20^{\text {th }}$ century was that many degree holders in late Qing no longer had any prospects in the public sphere after the end of the civil service examinations; they returned to their localities and created a large labour pool for potential Sishu teachers (Liao, 1936, p. 20).

${ }^{131}$ A movement for sishu reform began in Jiangsu in 1904, and then spread to other regions of China and was finally taken up by the central government in 1910 (Borthwick, 1983, pp. 19-21; Jiangsu Jiaoyu Gailan (The education reports for Jiangsu province), 1933).

${ }^{132}$ The Sishu remained widespread only until 1949, when the Communist Party forcibly carried out a sweeping elimination of them. In order to transform China into a socialist state-ownership system, the Communist party on accessing power demolished the whole private sector. Along with this economic and political line, private schools, including Sishu, which comprised $40 \%$ of all educational institutions, were forced to disappear once the Party established its rule in 1949 (P. Deng, 1997, p. 8).
} 
As the Sishu lacked the official status of recognized educational institutions under the Republican government (both the Beiyang and the later Nationalist governments), neither educational yearbooks nor national surveys carry a record of them. Without systematic data on enrolment records, it is impossible to estimate the average national enrolment ratio for Sishu. However, via scattered fragments of regional data, one important clue to their level and the changing patterns of Sishu enrolment ratios can be followed.

\section{Regional benchmarks}

At the very beginning of the Republican period, it is obvious that the Sishu outnumbered the modern primary schools. Using county gazetteers for 10 counties from 5 different provinces across China, Hu reports that between 1907 and 1911, when modern education had just been introduced, the highest enrolment ratio for Sishu was 23 percent (for a county in Zhejiang province), the lowest was 8.8 percent (for a county in Fujian province) and overall the average figure stood at 14.9 percent (Hu, 2009). To put this figure into perspective, even the lowest Sishu enrolment ratio among the 20 counties (8.8 percent) was in 1912 more than 4 times the level for modern primary schools (2 percent).

Figure3.2: Relationship between modern primary schools and Sishu

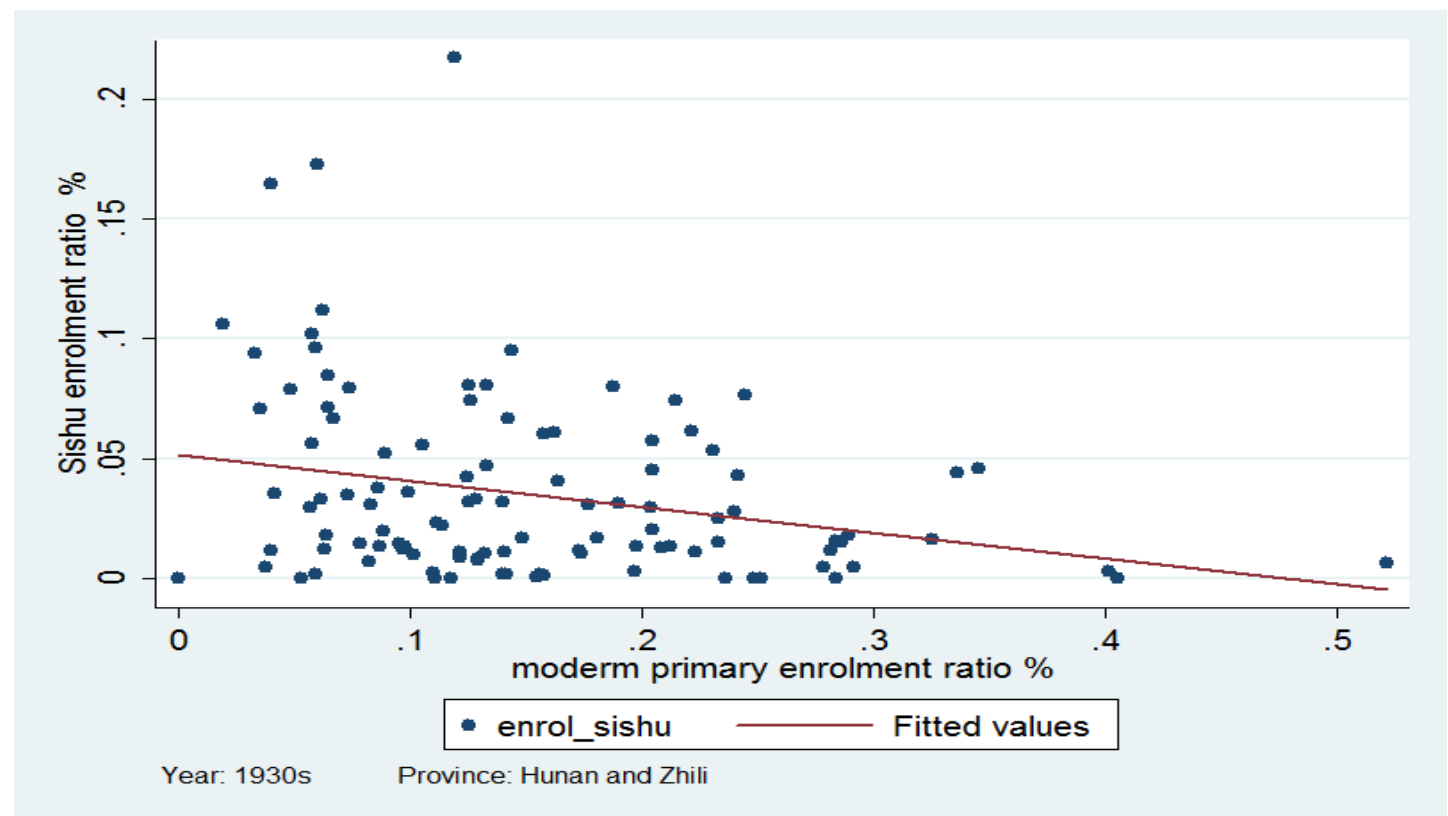

*Source: (Hebeisheng Gexian Putong Jiaoyu Gailan (The county-level reports for general edcuation in Hebei province), 1928; Hunan quansheng Jiaoyu Tongji (The education reports for Hunan province), 1931). 
But things seem to have changed so substantially in the proceeding decades that the Sish $u$ reduced their share of the primary education sector. For instance, in 1930 the province of Hunan reported the development of its primary schooling in each county; this report is one of the very few provincial education reports documenting data on registered Sishu enrolments. The enrolment ratio for the Sishu was only 3.1 percent, which was one-fifth of the modern primary school enrolment ratio in the same year (17.7\%) (Hunan quansheng Jiaoyu Tongji (The education reports for Hunan province), 1931). Similarly, Zhili province reported the enrolment figures covering all counties in the 1930s and the results present a similar pattern: that the enrolment ratios for Sishu were much lower than the one for modern primary schools in the 1930s (Hebeisheng Gexian Putong Jiaoyu Gailan (The county-level reports for general edcuation in Hebei province), 1928). According to Figure 3.2, the negative relationship between modern primary schools and Sishu evidently indicates that the relationship between the modern primary school and that Sishu allowed them to substitute for each other.

The Sishu prevailed in urban centres, and were if anything more prevalent in rural regions. In the preface to 'Statistics of Chinese education' published in 1923, the editor particularly specifies that in Nanjing city, one of the major metropolitan centres in China of the time, the Sishu numbered more than 500, accommodating about 12,000 students. The city of Canton reveals a similar figure; here approximately 20,000 students were enrolled in 1000 Sishu. In both cities, the number of students attending Sishu was much larger than the number of all students in modern primary schools (Tao, 1923, p. 6).

Without more systematic and representative estimates on Sishu, it is difficult to build a conclusive argument; but two important patterns can be identified. First, the rise of modern schooling heavily reduced the number of Sishu. There is no denying that traditional style primary schools declined gradually, to be replaced by substantially increasing numbers of modern primary schools. However, even as it declined; the presence of Sishu across China endured throughout the first half of the $20^{\text {th }}$ century as an alternative to the modern primary school. ${ }^{133}$ More importantly, all the calculations

\footnotetext{
${ }^{133}$ The persistence of Sishu can be explained by a few factors. First, when it came to affordability, Sishu had some advantages. The tuition fees for Sishu were much lower than those of modern primary schools. According to regulations from the Ministry of Education, the yearly fee for lower primary schools was
} 
on enrolment ratios in the previous section exclude Sishu and they tend to underestimate the actual proportion of the Chinese population who received some equivalent to primary education between 1900 and $1950^{134}$. However, the more intractable challenge of taking Sishu into account lies in how to adjust for the quality of different types of primary education.

In short, modern primary schooling spread nationwide at an impressive speed in China through the first half of the $20^{\text {th }}$ century; after several exceptionally difficult episodes, universal primary schooling finally arrived in the 1980s. However, if the traditional track of primary schooling is taken into account, the picture becomes slightly different for the early decades of the $20^{\text {th }}$ century; the estimates of modern primary enrolment ratios underestimated the real proportion of the population who received a certain level of basic education during the first half of the $20^{\text {th }}$ century. If the Sishu are included, they bring China well above India and Brazil in primary enrolment ratios, but still a long way below Japan.

\subsection{The limited rise of secondary education}

In this section, we turn to measuring the rise of secondary education. The progress of secondary education must have been based on a firm foundation of primary schooling, which created a pool of eligible primary school graduates demanding secondary education. The successful spread of universal primary education in most advanced nations preceding World War II led to the launch of the 'High school movement', headed by the USA, after the 1940s (Black \& Sokoloff, 2006; Goldin \& Katz, 2008, pp. 194-246). In contrast, because most Chinese were still striving to attend primary school, the primary enrolment ratio was lower than 30 percent through the first half of the $20^{\text {th }}$ century and naturally only a selected minority of these could proceed to secondary

around four yuan (twelve yuan for higher primary schools); while a child attending Sishu was charged less than two Yuan(F. Wang, 1994)。 Second, the short distance to the school was another factor to favour the Sishu. Modern primary schools were not widely prevalent in rural areas; therefore, people were more inclined to enrol their children in the local Sishu than in a distant primary school that might be was well outside their own village. Last but not least, according to the regulations of the Ministry of Education at the time, the recruitment for modern schooling was remarkably open and liberal, in that students were allowed to transfer easily from Sishu to modern primary schools, or graduate from Sishu and pursue their education in modern secondary schools (P. Deng, 1997, p. 8).

${ }^{134}$ As most of the developing countries continued with their indigenous educational systems through a comparable time period, and most of them did not include indigenous education in other studies either, this underestimate probably has only a minor impact on international comparisons. 
education. In theory, secondary education comprised general secondary education, vocational schooling and secondary normal schooling; and this section addresses each stream of secondary education separately.

\subsubsection{General secondary schooling}

Figure 3.3 presents the pattern of change in the secondary enrolment rates from 1907 to 1949. Here, the enrolment data for secondary schooling refers only to students enrolled in general secondary schools, excluding secondary normal schools and vocational schools. In addition, according to education regulations, we employ 12-17 as the age group for secondary schooling (12-14 for lower secondary schools and 15-17 for higher secondary schools $)^{135}$. One thing worth mentioning is that we not only calculate the total enrolment ratio series, but also construct a separate enrolment for junior secondary schools and senior secondary schools after 1931, when separate enrolment records for the two began to be kept. ${ }^{136}$ In the same vein, international comparison results of Chinese secondary schooling enrolment ratios with those of the United States, India and Japan are reported in Table 3.2. ${ }^{137}$

As illustrated in Figure 3.3, the enrolment ratios for secondary education barely grew between 1907 and 1927. In 1912, the ratio was only 0.103 percent, meaning that there was only about one in every 1000 in the relevant school-age group was attending secondary school. Compared to the strikingly high level of India's secondary enrolment ratio, 2 percent, and Japan's 13.9 percent, China in the 1910s lagged far behind. Between the 1920s and the 1930s, the speed of secondary schooling expansion

\footnotetext{
${ }^{135}$ As pointed out in section 4.1 of Chapter Two, the duration of secondary schooling changed a few times over the Republican period. Under the Regulation of Education Act 1904, secondary schooling was for 4 years only; accordingly, the school-age group would have been 16-19. In 1912, the length of secondary schooling did not change, but given that primary schooling reduced its duration, the corresponding age group for secondary education became 14-17. Again, the model was changed in 1922 and emulated the US education system; the length of time for secondary schooling became 6 years, consequently the school-age cohort changed to 12-17. The frequent changes in the corresponding school-age group for secondary education made it difficult to identify one specific age group from which to estimate enrolment ratios for secondary education.

${ }^{136}$ Compulsory education in China today covers only 9 years (primary education and junior high school); hence, the graduate ratio for junior secondary school is very important.

${ }^{137}$ Unlike the wide consensus to define the primary school age cohort as 5-14, scholars apply different age groups to secondary schooling, which makes international comparison more challenging. For instance, Goldin applies the range 14-17 to secondary schooling in the US (Goldin, 1998), Leewuen applies 12-17 to Japan (Leeuwen, 2007), Broadberry simply uses people under the age of 20 as the nominator (Broadberry, 2004), and Latika applies 15\% of the population as the figure for school-age children (Chaudhary, 2009).
} 
accelerated. The enrolment ratio grew by more than three times, rising from 0.2 to 0.7 percent. This short period of its prospering may be attributed to the separation of lower secondary school and higher secondary school in 1922 (Shu, 1928, p. 80). ${ }^{138}$ Issuing lower secondary school diplomas to students who finished 3 years of secondary schooling partially accounts for the significant decline in the number of dropouts.

Figure 3.3 Gross enrolment ratios in secondary education, 1907-1949

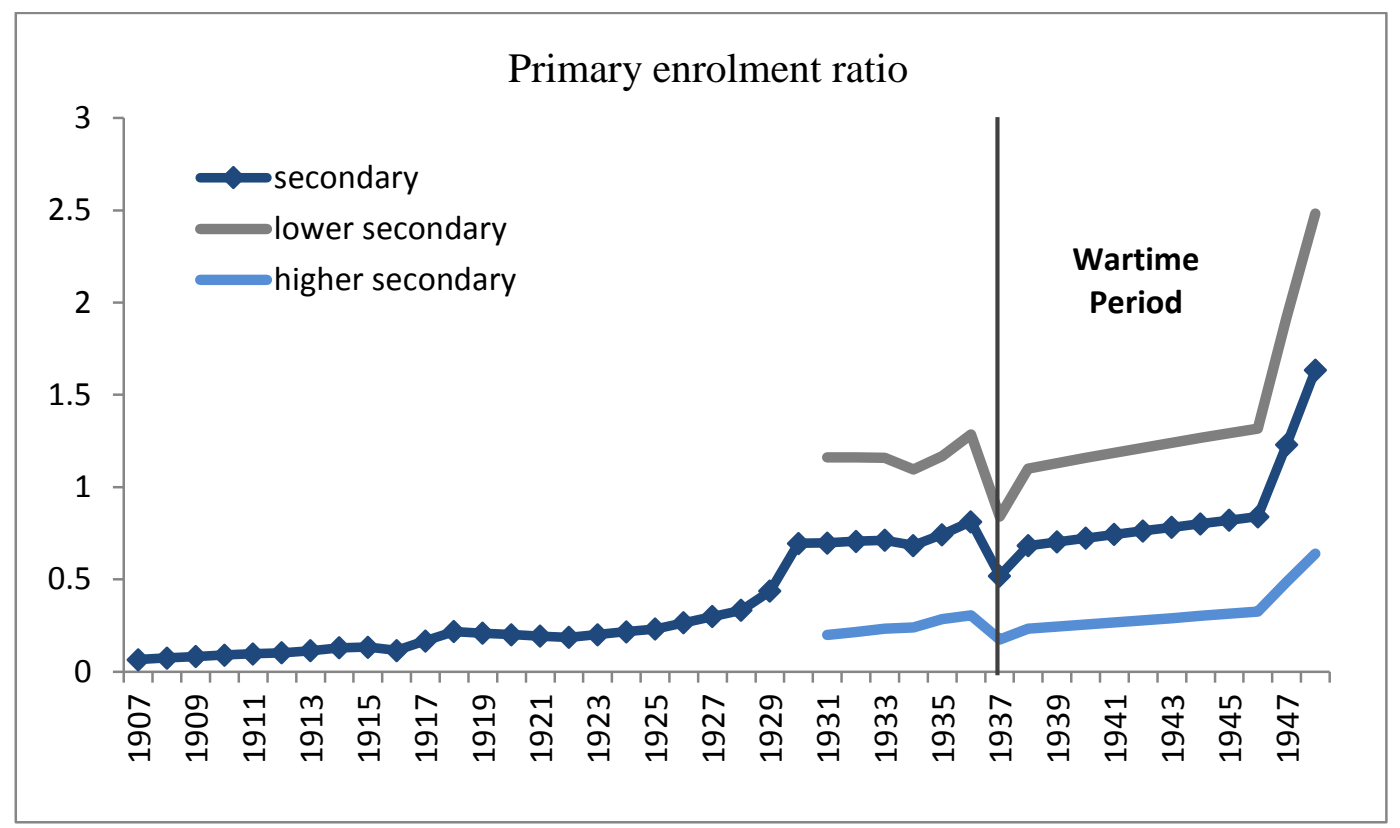

*Source:

i. enrolment data: Chinese Yearbooks on Education in corresponding years.

ii. Population and age structure: (Hou, 2001)

In contrast to the sharp drop of primary education during the war, only a very short window of disruption to the progress of China's secondary education was created by the Japanese invasion. The enrolment ratio fell substantially in the first two years after the war; however, it bounced back quickly and the number rose at unprecedentedly rapid rates during the civil war period, from 0.5 percent in 1945 to 2.1 percent in 1948. This was mainly driven by the increasing number of private secondary schools, as mentioned in Chapter Two. ${ }^{139}$

\footnotetext{
${ }^{138}$ As displayed in the Table 2.6, Chapter Two, the education model was promulgated by the Ministry of Education in the Education Act of 1925, which changed the education structure from 7-4-4 to 6-6-4. While the length of secondary school was extended to 6 years, it was further divided into junior and senior secondary schools, each of which had a separate diploma to grant to its graduates.

${ }^{139}$ As displayed in Figure2.2, Chapter Two, private secondary schools increased rapidly, most of all through the wartime period. In 1912, most secondary schools were public $(87.9 \%)$, while in 1946 the
} 
Table 3.2: Secondary Enrolment Ratios per 1000 population

\begin{tabular}{cc|cccc}
\hline Year & China & Year & Indian & Japan & $\begin{array}{c}\text { United } \\
{ }^{140} \text { States }\end{array}$ \\
\hline 1907 & 0.7 & 1890 & 16.4 & 26.5 & \\
1912 & 1.2 & 1900 & 21.2 & 50 & 106 \\
1915 & 1.7 & 1910 & 35.1 & 132.4 & 145 \\
1922 & 2 & 1920 & 42.1 & 310.7 & \\
1930 & 7.5 & 1930 & 65.7 & 505.4 & 511 \\
1937 & 7.6 & 1940 & 75.4 & 589.7 & 677 \\
1945 & 5.4 & 1945 & 85.3 & 767.9 & \\
1949 & 20.7 & 1950 & 166.1 & 695.1 & 745 \\
\hline
\end{tabular}

*Source:

i. .China's enrolment data come from Chinese Yearbooks on Education in corresponding years; and population data is from (Hou, 2001).

ii. Data for the United States comes from (Goldin, 1998, p. 27); while data for Japan and India comes from (Leeuwen, 2007)

If we put China's progress in secondary education into international perspective, the picture is less satisfactory. By the 1940s, the United States had already finished its great 'high school movement' and was approaching universal senior secondary education, while the enrolment ratios for secondary schooling in Japan and India were 59 percent and 8 percent respectively. Comparatively speaking, the secondary education enrolment ratio still stood at less than 1 percent in China, indicating that secondary schooling was much less widespread there than in its Asian counterparts, let alone in the major Western countries.

For the second half of the $20^{\text {th }}$ century, the enrolment ratios for secondary education rose rapidly during the first few years of the Mao period, followed by several fluctuations. ${ }^{141}$ Because of a programme launched to promote mass secondary education

private secondary schools accounted for half the total number. The number of private secondary schools rose from 523 in 1938 to 1937 in 1945; their enrolment increased from 155,688 in 1938 to 581,052 in 1945. It is highly likely that when public funds failed to provide enough schooling to match the demand, an increasing number of private educational institutions stepped into the market to meet the need.

${ }^{140}$ Data for USA presented here is the senior secondary enrolment ratio (school age is defined as 14-17) to secondary schooling in the US (Goldin, 1998)

${ }^{141}$ Not surprisingly, the changes in the enrolment ratio in secondary schooling deviated from the secular trend during the Mao period. The number dropped after the beginning of the Great Leap Forward and 
from 1955, a significant number of secondary schools were built in rural China, resulting in an increase in the enrolment ratio to 49 percent in 1977. The aggressive educational expansion could not be sustained and the ratio gradually returned to a regular trend. The enrolment ratio for secondary education rose rapidly after the 1980s, in particular after 1986 when a law on compulsory education was introduced; this obliged every child to receive 9 years of education, including 3 years of lower secondary schooling (Wikisource, 2013). ${ }^{142}$

Figure 3.4: Gross enrolment ratios in secondary schooling, 1949-2005

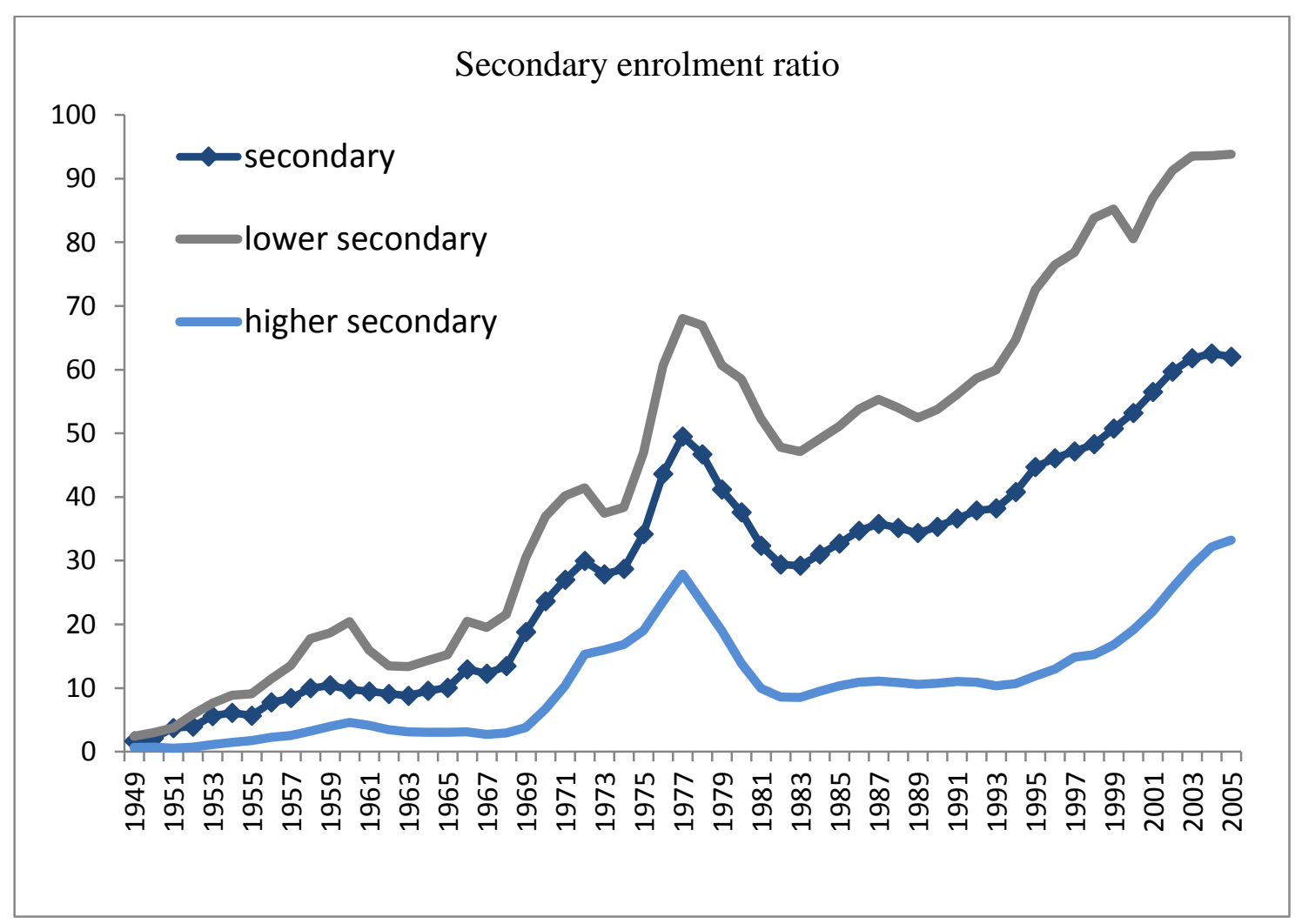

*Source:

i. enrolment data: (Zhu, 1948, p. 1428);

ii. Population and age structure: (Hou, 2001)

stagnated at the same level until 1968. As mentioned, the damaging effect of the Cultural Revolution on education was mostly focused on tertiary education; even with several fluctuations, the enrolment ratio in secondary schooling managed to increase steadily. We also see that higher secondary schooling was more under attack than lower secondary schooling, which is consistent with what most of the historical literature suggests. In order to effect a thorough reform of the educational system, a closure order, which targeted higher secondary schools and universities, was launched in 1966 (T. H.-e. Chen, 1974, p. 25).

${ }^{142}$ The Law on Nine-Year Compulsory Education (中华人民共和国义务教育法), which took effect on July 1, 1986, established requirements and deadlines for attaining universal education tailored to local conditions and guaranteed school-age children the right to receive at least nine years of education (sixyear primary education and three years secondary education). 


\subsubsection{Vocational schooling and normal schooling}

Formal schooling, with its emphasis on academic content and general knowledge, constitutes only one stream of education. Vocational training which provides jobspecific skills and normal education which targets teacher training are also important aspects of human capital formation. From global accounts, the expansion of vocational schools and a flourishing apprenticeship system had long been vital for supporting the growing industrial sector in Europe, for Germany in particular and perhaps the UK as well (Broadberry, 2004). The late- developing world presented a very different pattern in terms of vocational education, where it remained a minor line in the secondary education sector; for instance the share of students in 1970 on the vocational track of secondary schooling was only 10.1 percent for Asia and the figure has dropped further in recent decades (UNESCO, 2000).

Table 3.3: Composition of Secondary school (general/normal/vocational)

\begin{tabular}{|c|c|c|c|c|c|c|c|}
\hline \multirow{2}{*}{ Year } & \multicolumn{4}{|c|}{ School type } & \multicolumn{3}{c|}{ Percentage (\%) } \\
\cline { 2 - 8 } & Total & General & Normal & Vocational & General & Normal & Vocational \\
\hline 1912 & 832 & 500 & 253 & 79 & 60.1 & 30.4 & 9.5 \\
\hline 1916 & 962 & 652 & 198 & 84 & 67.8 & 20.6 & 8.7 \\
\hline 1922 & 1096 & 547 & 385 & 184 & 49.9 & 35.1 & 16.8 \\
\hline 1930 & 2992 & 1874 & 846 & 272 & 62.6 & 28.3 & 9.1 \\
\hline 1937 & 1896 & 1240 & 364 & 292 & 65.4 & 19.2 & 15.4 \\
\hline 1941 & 2812 & 2060 & 408 & 344 & 73.3 & 14.5 & 12.2 \\
\hline 1945 & 5073 & 3727 & 770 & 576 & 73.5 & 15.2 & 11.4 \\
\hline
\end{tabular}

*Source (Zhu, 1948, p. 1428)

The first attempt to provide modern technical training in China began quite early, in the 1860s. From this date, more and more vocational schools were encouraged to provide procedural knowledge, at a comparable level to secondary schooling (F. Wang, 1994, pp. 340-373). ${ }^{143}$ In the same vein, for the development of a newly established and expanding modern education model, training more qualified teachers was acknowledged to have crucial importance; normal schools were therefore largely promoted by the government throughout the period, as well. According to Table 3.3, normal and vocational education clearly grew fast, along with the general secondary education;

\footnotetext{
${ }^{143}$ Detailed information on the system of vocational education and normal education can be found in Table 2.6, Chapter Two.
} 
however, of the three tracks, the progress in general schooling dominated, leaving vocational and normal schooling as peripheral contributors.

Figure 3.5 shows that enrolment ratios for normal schools and vocational schools had the same changing trajectories as general secondary education had. They grew very slowly in the first two decades after the advent of the Republic of China and enjoyed a boom during the golden age between 1927 and 1937. After a sharp fall during the Second World War, their increasing momentum for both vocational and normal education was sustained until the end of the 1940s. Several points should be borne in mind when interpreting these series. First, secondary normal education spread faster than vocational schools, which is easy to understand. In a new and expanding education system, providing more and more eligible teachers would have been the priority for keeping the new education system running. Furthermore, the name 'vocational schools' is given here only to the formal vocational schools that provided technical training, but excludes the apprenticeship system that existed in many handcraft manufacturing sectors in China. Third, the enrolment ratios for both vocational and normal schools were considerably lower than for general secondary education. For instance, in 1946, the peak point of vocational enrolment ratios was below 0.2 percent and for normal schools, the figure was only about 0.35 percent, while the ratio for general secondary schools stood at around 2 percent.

Figure 3.5: Gross enrolment ratios (normal school vs. vocational school)

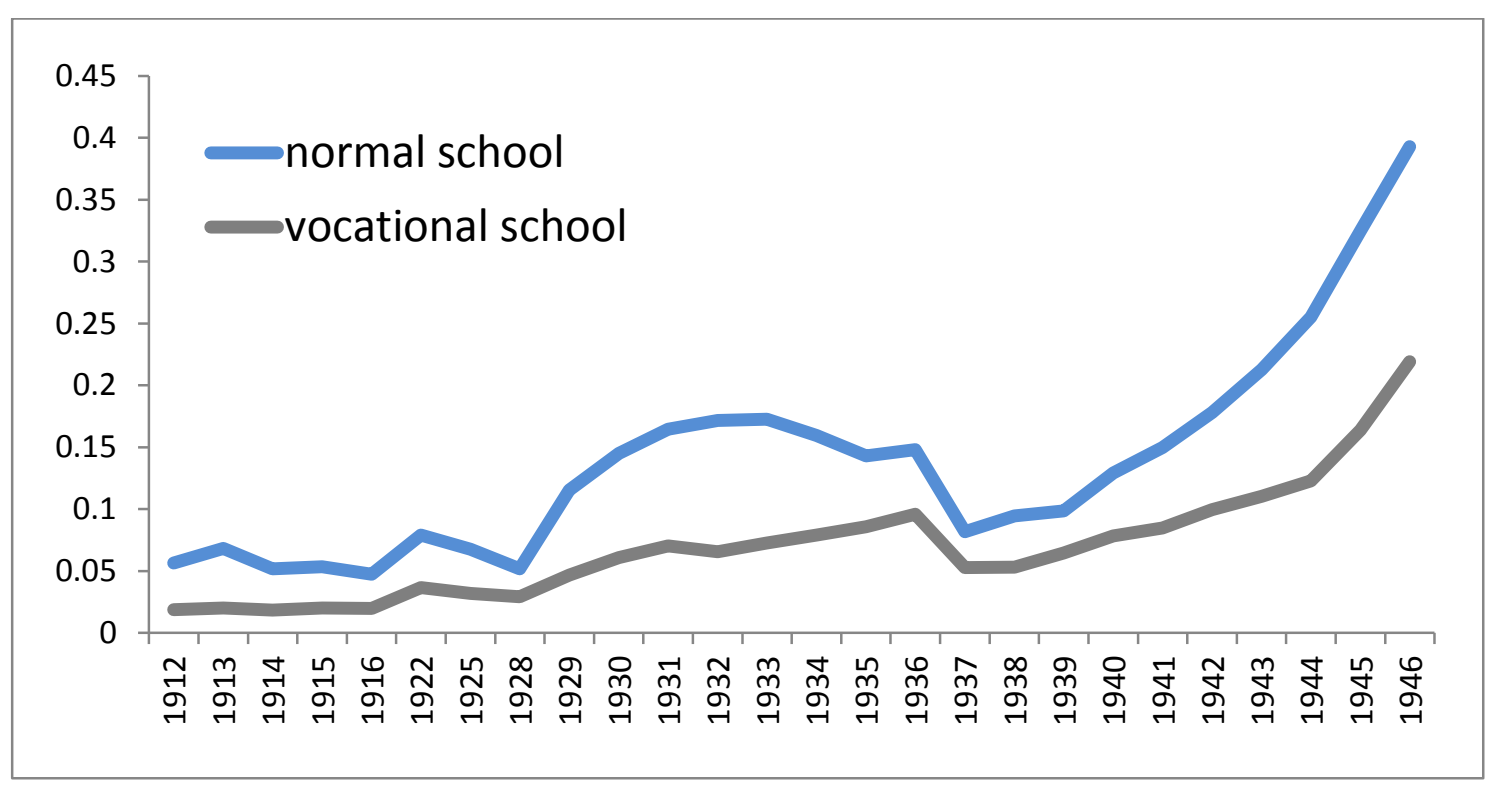

*Source: schooling: (Zhu, 1948, p. 1428); population and age structure: (Hou, 2001) 
In conclusion, the diffusion of secondary education, both general track and vocational/normal track, had only limited success through the first half of the $20^{\text {th }}$ century and can mainly be attributed to the rise of lower secondary schools and the increasing relative importance of private schools. In regard to the second half of the $20^{\text {th }}$ century, substantial progress was made in expanding secondary education, which contributed to attaining the goal of universal education for all schoolchildren up to the 9th grade.

\subsection{The shaping of higher education}

Without breadth of access to a basic education, college and university level schooling remained the preserve of members of the elites in China, a very limited group of people. The first university, which happened to be the first modern educational institution in China, was founded in 1862 -Tongwen Guan (同文馆); it later became a part of the Imperial Capital University (now Peking University) (Yang, 1934, p. 9).

Figure 3.6: Gross enrolment ratio in tertiary education, 1912-1946

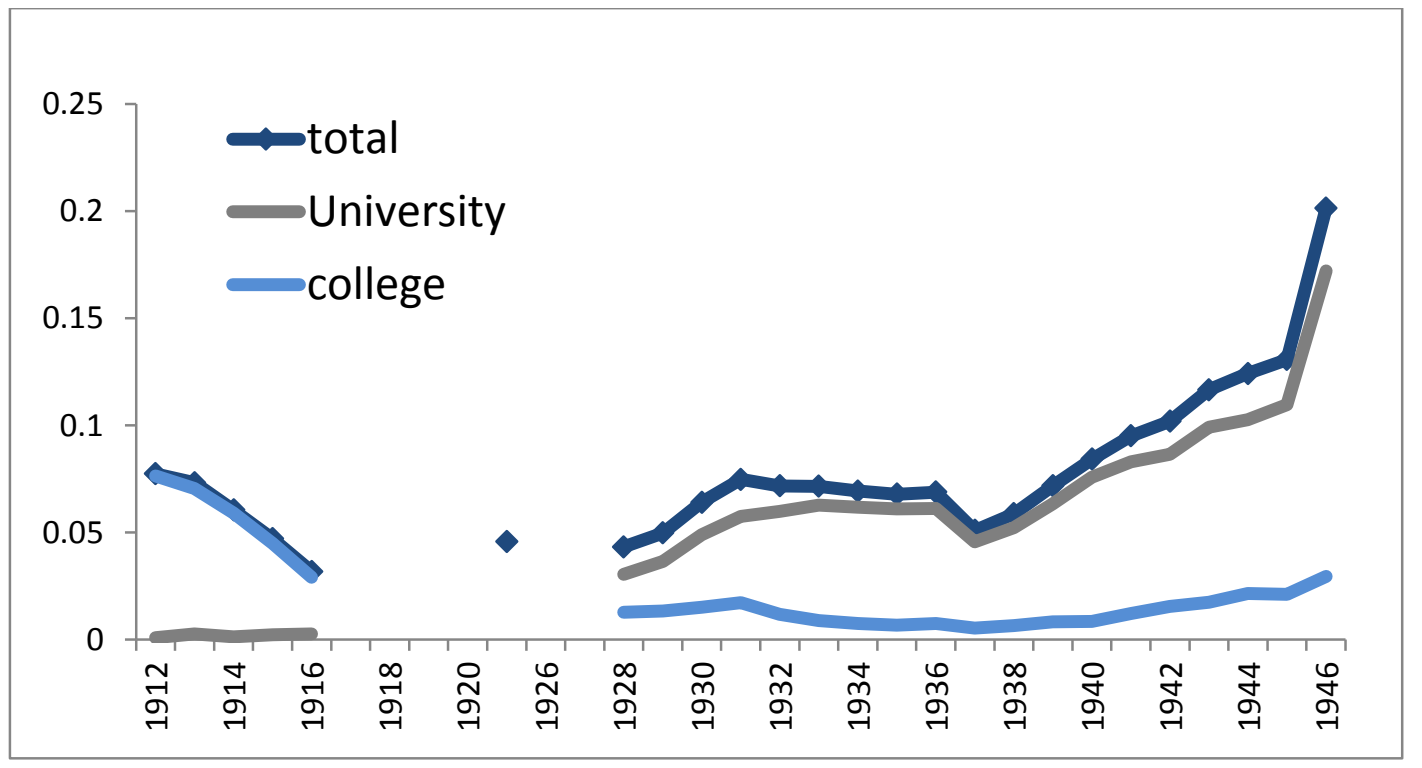

*Source: schooling(Yang, 1934, p. 60; Zhu, 1948, p. 1406); population and age structure (Hou, 2001)

Figure 3.6 displays the enrolment ratios for tertiary education throughout the first half of the $20^{\text {th }}$ century, universities (with a 4-year programme) and colleges (usually referring to institutions that offered a 2-year programme) being shown separately. It is difficult to assign a proper age band to tertiary education, not only because the relevant educational regulations changed frequently, but, more importantly, because of the 
presence of so many over-age and under-age students in tertiary education, compared to those in primary and secondary schooling. In Figure 3.6, the age band employed is 1821. Throughout the first three decades, tertiary education experienced no progress, perhaps even an actual decline. The enrolment ratio in 1907 stood at 0.07 percent and stayed at the same level for several decades. A substantial increase occurred only after the $1940 \mathrm{~s}^{144}$ and the ratio reached 0.21 percent in 1949. To put Chinese figures into perspective, a much higher level of enrolment in tertiary education had already been reached in Japan - its enrolment ratio was 4.05 percent, while even India reached 0.48 percent, i.e. more than 3 times the level for China.

Table 3.4: Tertiary Enrolment Ratios, per 1000 population

\begin{tabular}{cc|ccc}
\hline Year & China & Year & India & Japan \\
\hline 1907 & 0.07 & 1900 & 0.9 & 5.7 \\
1912 & 0.07 & 1910 & 1.3 & 10.7 \\
1922 & 0.05 & 1920 & 2.6 & 15.9 \\
1937 & 0.05 & 1930 & 3.1 & 29.8 \\
1945 & 0.13 & 1940 & 4.8 & 40.5 \\
1949 & 0.21 & 1950 & 10.8 & 46.5 \\
\hline
\end{tabular}

*Source:

i. China's schooling data is from (Yang, 1934, p. 60; Zhu, 1948, p. 1406); and population and age structure (Hou, 2001).

ii. Data for Japan comes from (Leeuwen, 2007)

Under Communist Party rule, tertiary education experienced several drastic disruptions, through the Great Leap Forward and the Cultural Revolution. As vividly portrayed in many historical narratives, tertiary education was the main target of attack during the Cultural Revolution, because of Mao's ideological goal of sweeping away bourgeois intellectuals. In 1966, the university entrance examination was abolished and almost all universities were shut down completely for one whole decade (Z. Deng \& Treiman, 1997). ${ }^{145}$ The university entrance examination was restored only in 1977 . Following the

\footnotetext{
${ }^{144}$ One thing worth stressing is that the Japanese invasion did not hugely damage tertiary education. Most of the universities, located in big cities, were able to take advantage of the relative safety of the international settlements and French concessions in these cities. Meanwhile the universities located in occupied China did not cease to operate; they merely fled south and continued to function throughout the war.

${ }^{145}$ Although the damaging effect of the Cultural Revolution is generally regarded as continuing for some 10 years, there was a gradual "return to normality" throughout the 1970s, since most universities began to reopen in 1972. But even with this, the quality of education remained low, because educational opportunity was still tied to political conformity and family origin, not to academic performance.
} 
economic reforms of 1978, the rise of tertiary education accelerated after the 1990s, above all when private universities were re-introduced in 1994. ${ }^{146}$

\subsection{Summary}

Throughout the $20^{\text {th }}$ century, changes in the educational model, the intervention of warfare, massive educational campaigns and political radicalism resulted in substantial fluctuations in educational progress and the extent of these influences for each level of schooling was different. As displayed in Figure 3.7, a pattern of educational development from primary to secondary and finally to tertiary education emerges in the Chinese case. In fact, for most of the $20^{\text {th }}$ century, the 'primary school movement' still constituted the main driving force behind the education expansion in China.

\section{Figure 3.7: Enrolment proportions in China (primary/secondary/tertiary)}

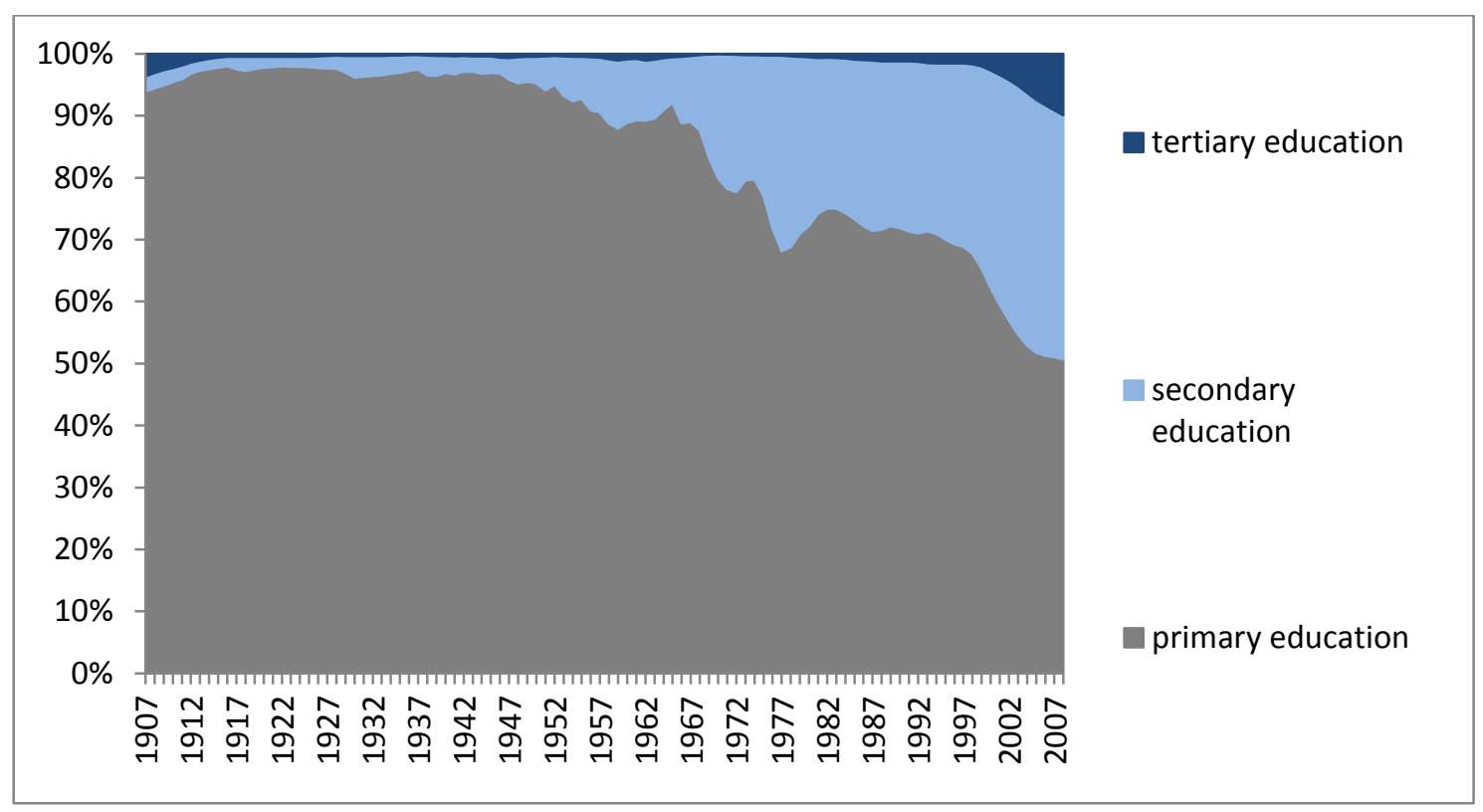

*Source: Same as in Figure 3.3, Figure 3.4, and Figure 3.6

\section{Measuring the Chinese Human Capital stock}

Gross enrolment ratios reflect only the flow of pupils into education. After the rise of growth theory in the 1950s (Becker, 1964), economists began to be more interested in the size of the human capital stock embodied in the current productive labour force of a

\footnotetext{
${ }^{146}$ In 1994, the Ministry of Education, for the first time, accredited six private higher institutions to issue graduate certificates.
} 
country. ${ }^{147}$ In response to a growing literature on growth accounting, studies on estimating human capital stocks across countries flourished (Barro \& Lee, 1993, 1996, 2001; Cohen \& Soto, 2007; Yoshihisa Godo, 2001; Krueger \& Lindahl, 2001; Kyriacou, 1991; Lau, Jamison, \& Louat, 1991; Wössmann, 2000).

Educational attainment is defined by the US Census Bureau Glossary as the highest level of education completed in terms of the highest degree or the highest level of schooling completed (US Census Bureau Glossary, 2000). Mean years of schooling, for their part, indicate the average number of completed years of education of a country's population (UIS).

Of the many studies assessing human capital stock across countries, there are a few which provide estimates for China after 1949; whereas few writers try to push back their timeline before 1949 , leaving the first half of the $20^{\text {th }}$ century remarkably underexplored. For instance, in their influential work, Barro and Lee offer an assessment of the average years of schooling for China from 1975 to 2000, based on census data (Barro \& Lee, 1996, 2001). Similarly, Yan Wang (2004) uses Barro and Lee's method to construct a measure of China's human capital stock from 1952 to 1999 . However, due to the unavailability of census data for the period before the 1980s, she draws on India's distribution of educational attainment to indicate the distribution in China, leading to some unreliable results. Deng and Treiman trace the figures back to the Mao period and uses data from the 1982 census of the People's Republic of China, presenting the educational attainment by birth cohorts throughout the Mao period (the 1950s to 1980s) (Z. Deng \& Treiman, 1997), focusing on how much the Cultural Revolution affected educational stock in China. Luween et al made the first attempt to quantify the human capital stock for the first half of the $20^{\text {th }}$ century, however, their study is highly relied on the number of people who participated in civil service examination and the assumed ratio of successful rate of passing each level of exam, which make the accuracy of this estimate suspicious(Yi Xu et al., 2013).

\footnotetext{
147 The main weakness of the flow variable is its time-lagged effect on the stock of human capital. The children currently enrolled in schools are not yet part of the labour force; therefore, current school enrolment ratios do not necessarily relate directly to the stock of human capital embodied in the current productive labour force of a country. The accumulated stock of human capital depends indirectly on the lagged values for school enrolment ratios, where the time lag between schooling and future additions to the human capital stock can be very long and also depends on the custom length of the education phase.
} 
In the following sections, long-term estimates of human capital stock are constructed to provide a general picture of China's educational development over the $20^{\text {th }}$ century. To begin with, the methodology and data are briefly introduced. Then we present an overall picture of the educational growth of successive birth cohorts of Chinese people in the $20^{\text {th }}$ century via two measurements: average years of schooling of 30-year olds and of the working-age population (15-64). Section three uses data from the first national individual survey (Chinese Household Income Project) as complementary evidence to not only confirm the previous results, but also to provide richer information on gender inequality and urban-rural dispersion in the Chinese educational stock. Finally, the educational stock years are compared to those of other nations.

\subsection{Methodology and Data}

The estimation of average years of schooling has to be derived from the educational attainment data. Therefore, we consider the estimation methodology for these two measurements together. Wössmann distinguishes three fundamental approaches (Wössmann, 2000) to estimating educational attainment. The first, pioneered by Barro and Lee, interpolates the census data for the years in between (Barro \& Lee, 1993, 1996, 2001; Cohen $\&$ Soto, 2007) ${ }^{148}$. This approach has the strict requirement of high quality census data at 5- or 10-year intervals. However, in China's case, the number of censuses is extremely limited; ${ }^{149}$ more importantly, only after the 1980 s did the questionnaires in the population census begin to include questions about education attainment. Thus, the Barro and Lee method cannot be applied in this study. The second approach is the Perpetual Inventory Method which is often employed in historical analysis. With a sufficiently long series of enrolment data available, the 'total school enrolment' for the corresponding years and ages can be accumulated after adjusting for changes in mortality, immigration, repeaters and drop-outs (Yoshihisa Godo, 2001; Yoshihiha Godo \& Hayami, 1999; Lau et al., 1991; Nehru, Swanson, \& Dubey, 1995; Schulze \& Fernandes, 2009). The third approach is the projection approach, which estimates the 'average years of schooling' from censuses for a few benchmark years based on lagged

\footnotetext{
${ }^{148}$ Many adjustments have been made to the basic Barro and Lee method by other scholars; for instance, the approach adopted by the UNESCO Institute for Statistics to the estimation of MYS (2010); however, the differences are quite small, and the methodological foundation remains intact.

${ }^{149}$ There were two national-scale censuses in China in the first half of the $20^{\text {th }}$ century, carried out in 1912 and 1947. However, very limited and scattered information on educational attainment was included in the answers. After the start of Communist rule, three national censuses were conducted before it became a 10-year regular routine; these were in 1956, 1964 and 1982.
} 
enrolment ratios (Kyriacou, 1991). Depending on the relationship between years of schooling and lagged enrolment ratios, the series of educational attainment figures can be projected backwards. In summary, in accordance with the availability of data on China, this paper mainly adopts the Perpetual Inventory method, but uses the projection approach in the following sections for further estimations.

\section{Perpetual-inventory approach}

The Perpetual Inventory method (superscript PIM) derives the relevant stock measures from the available flow data; therefore, educational attainment is directly built from the 'total school enrolment' for the corresponding years and ages.

$$
S_{t}^{P I M}=\sum_{t=T-A_{h}+D_{o}}^{T-A_{l}+D_{o}} \sum_{g} E_{g, t+g-1}\left(1-r_{g}-d\right) p_{g, t+g-1}
$$

where $E g, t$ is the total (gross) enrolment at grade level $g$ at time $t$, as in Equation (3.2), $A h$ is the highest possible age of a person in the labour force, i.e. 64; and $A l$ is the lowest possible age of a person in the labour force, i.e. 15. $D_{o}$ is the age at which children enter school, typically assumed to be 6 years; $r_{g}$ is the ratio of repeaters to enrolments in grade $g$ (assumed to be constant across time), $d$ is the drop-out rate (assumed to be constant across time and grades) and $p_{g, t}$ is the probability of survival until the year $T$ for an enroller at grade $g$ at time $t$.

The key challenge of applying Perpetual Inventory in historical analysis is the high requirement comprehensive enrolment records. According to Equation (3.2), estimating the average years of schooling for the working age population for a given year requires enrolment records going back over the previous 58 years. To capture the estimate for a single year, if only for one age cohort at age 30, the enrolment data must go back 24 years. Furthermore, in most historical analyses, for the sake of simplicity and if data are unavailable, no corrections can be made for repeaters and drop-outs.

\section{$\underline{\text { Projection approach }}$}

In order to project estimates to periods in an earlier epoch, there is a short-cut approach

- the projection method. If one assumes that the relationship between educational attainment and lagged enrolment ratio is stable, regressing the educational attainment on 
lagged enrolment to derive an equation with which to estimate the average years of schooling for the missing years is a valid solution. Kyriacou finds that this relationship is strong across 42 countries (Kyriacou, 1991; Wössmann, 2000).

\section{$\underline{\text { Data }}$}

In order to estimate human capital stock in China over the $20^{\text {th }}$ century, at least three sets of annual data are required: the size of the total population, the age structure and student enrolment numbers at primary, secondary (junior high school and senior high school) and tertiary levels.

One vital point to bear in mind when interpreting the results in the following sections is that the series of enrolment figures used to calculate the educational stock variables include only records from the formal modern educational system. As discussed in section 2.1.2, above, the traditional educational system was still important in China throughout the first half of the $20^{\text {th }}$ century; neglecting the enrolments for Sishu would severely underestimate the total human capital attained in the first few decades of the $20^{\text {th }}$ century. ${ }^{150}$

\subsection{China's catching-up in educational stock}

\subsubsection{The average years of schooling of 30-years old}

Even though the average years of schooling of the workforce is the most common indicator used in the literature, we start our analysis by applying the PIM to more defined age cohorts and to assess the average years of schooling of each birth cohort measured at the age of 30, when presumably everyone has completed formal schooling. If we do so, we can project the annual enrolment series to a much earlier period and also provide more insights into how the educational stock changed over time. The enrolment records are available from 1900 and we assume that the children who began to receive education at the same age as the age group we are looking at are now 30 years old; the

\footnotetext{
${ }^{150}$ Studies on estimating human capital for other developing countries encounter similar problems as well; however, the downward bias might be smaller compared to China, because the size of their indigenous education system was relatively small. Under Western or Japanese imperialism and colonisation, a modern educational system was established earlier in the above countries than in China and their indigenous educational system deteriorated in the $18^{\text {th }}$ and $19^{\text {th }}$ centuries, leading to relatively small provision for traditional education at the beginning of the $20^{\text {th }}$ century.
} 
series of average years of schooling can be traced back to the birth cohorts born as early as 1894 .

Figure 3.8: Years of schooling by birth cohorts at age 30 years

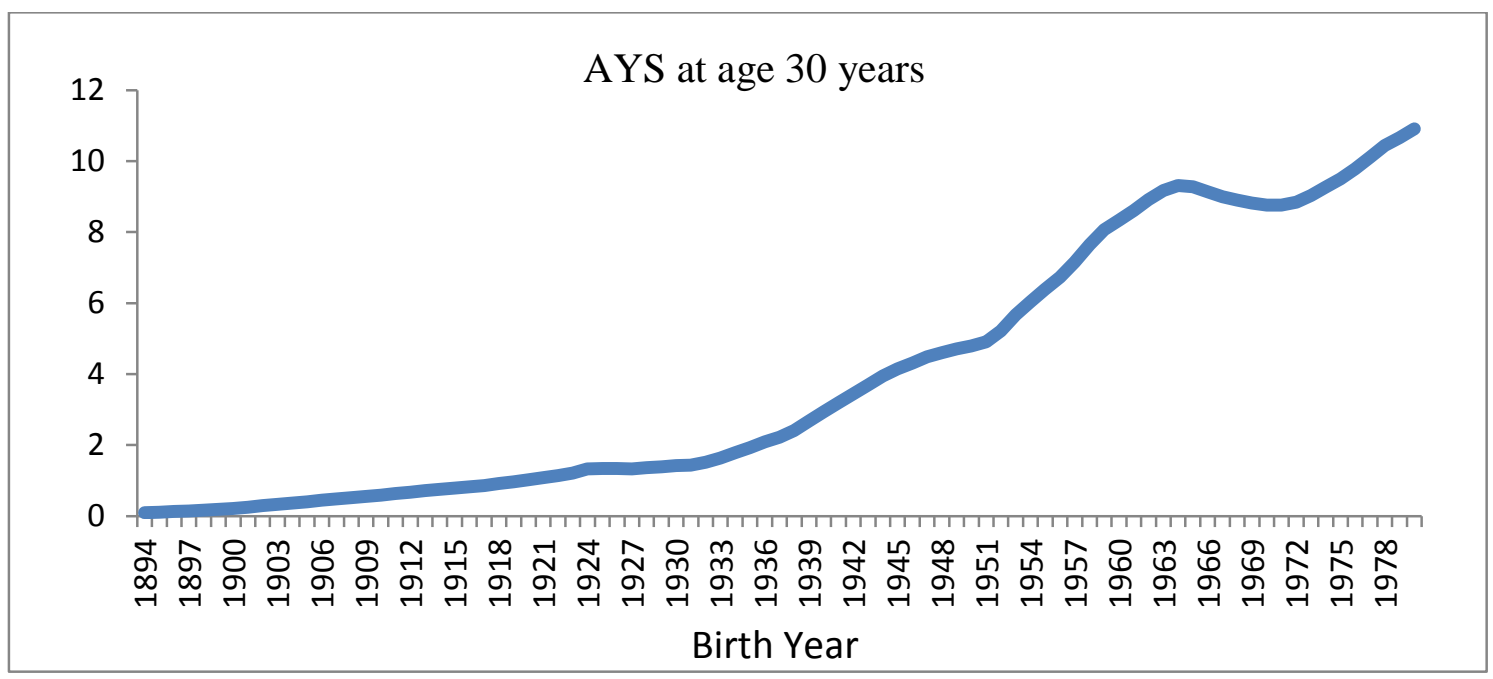

*Source: see Figure 3.3, Figure 3.4, and Figure 3.6

Figure 3.8 plots the average years of completed schooling for the Chinese population, adjusted to age 30 using the PIM approach. From the late $19^{\text {th }}$ century to the 1980 s, for people born in this period, the average years of schooling rose substantially from little above 0 to over 10 years. The period can be roughly divided into several sub-phases. First, if we assume that people normally stayed in the education system from 6 to 22, most of the cohorts born before 1924 (who were 30 between 1924 and 1954), presumably received their education during the first half of the $20^{\text {th }}$ century, ${ }^{151}$ when the average years of schooling grew slowly and steadily, by 0.4 years per decade. The second sub-period was a short phase of stagnation. The figure barely changed for the generations born between 1924 and 1933 (who were 30 years old between 1957 and 1963). This age cohort received education between 1930 and $1955 .{ }^{152}$ However, a great acceleration occurred afterwards, for the cohorts born between 1933 and 1965 (who were 30 years old between 1963 and 1995). ${ }^{153}$ The rate accelerated remarkably; the average years of schooling rose from 1.63 years to 9.1 years, implying a growth of 1.9 years per decade, which is an impressive rate rise, even compared to the USA during its

\footnotetext{
${ }^{151} \mathrm{We}$ assume that school age starts at 5 and normally ends at 22. In this case, for people born between 1894 and 1924, the period for which they were supposed to attend school fell some time in the years between $1900(1894+6)$ and $1946(1923+22)$.

${ }^{152}$ Similarly as noted in footnote 43, people born between 1924 and 1933 were supposed to attend school some time between $1930(1924+6)$ and $1955(1933+22)$.

${ }^{153}$ Again, people born between 1933 and 1965 were supposed to attend school some time between 1939 $(1933+6)$ and $1987(1965+22)$.
} 
so called 'human capital century'. ${ }^{154}$ A small anomaly is seen for people born between 1965 and 1970 (who were 30 years old between 1995 and 2000), who would have received education between 1971 and 1992. But very quickly the series went back to its regular trend and the average years of schooling started to rise again after the 1970 birth cohorts.

\subsubsection{The average years of schooling of the working-age population}

The average years of schooling of the workforce is the most standardised indicator for educational stock, which directly indicates the amount of human capital embodied in the whole labour force; it can also be further used in growth accounting to estimate the impact of education on economic growth. ${ }^{155}$ In this section, we offer estimates on human stock of the workforce at various points between 1920 and 2000, estimated by the Perpetual Inventory methodology and a slightly modified version of the projection method.

Because no records are available for the dropout rates and repeaters, we modify the PIM strategy for our estimation:

$$
S_{t}^{P I M}=\sum_{t=T-A_{h}+D_{o}}^{T-A_{l}+D_{o}} \sum_{g} E_{g, t+g-1} \times p_{g, t+g-1}
$$

where $E g, t$ is the total (gross) enrolment at grade level $g$ at time $t$, as in Equation (3.3), $A h$ is the highest possible age of a person in the labour force, set at 64; and $A l$ is the lowest possible age of a person in the labour force, set at $15 . D_{o}$ is the age at which children enter school, typically assumed to be 6 years; and $p_{g, t}$ is the probability of survival until the year $T$ for an enroller at grade $g$ at time $t$.

The key challenge of applying the Perpetual Inventory in our case is the data requirement for enrolment records. According to Equation (1), estimating the average years of schooling for the 15-64 working age population for a given year requires enrolment records going back 58 years. Unfortunately, the earliest records of modern

\footnotetext{
${ }^{154}$ For the US birth cohort born between 1876 and 1951 (who are supposed to receive education between 1882 and 1973), education expanded most rapidly, the average schooling of a 35-year old increased by 0.82 years per decade (Goldin \& Katz, 2008, p. 19).

${ }^{155}$ Applying educational stock series in growth accounting is far beyond the scope of this study.
} 
schooling enrolments in China start only at around $1900 ;{ }^{156}$ thus, with PIM, the earliest figure that we can calculate from the enrolment data is the year 1958. The other problem is that there are no enrolment data at grade level before 1990s; hence, we can use only the enrolment figures at each schooling level: primary, secondary (junior high and senior high) and tertiary.

Given the limitations, we resort to Projection Method to cover the first half of the $20^{\text {th }}$ century. We regress the educational attainment obtained on the basis of the PIM on lagged enrolment to derive an equation with which to estimate the average years of schooling for the missing years

$$
S_{T}^{\text {project }}=a_{0}+a_{1} e_{\text {pri,t-20 }}+a_{2} e_{\text {sec }, t-5}+a_{3} e_{\text {hig, } t-5}
$$

where $S_{T}^{\text {project }}$ is the projected average years of schooling at time $t$; $e_{\text {pri,t-15 }}$ is the enrolment ratio of primary schooling at time $t-20$; similarly $e_{s e c, t-10}$ is the enrolment ratio of secondary schooling at time $\mathrm{t}-10$; and $\mathrm{e}_{\mathrm{hig}, \mathrm{t}-5}$ is the enrolment ratio of secondary schooling at time t-5. ${ }^{157}$

Table 3.4: Regression results for the projection approach

\begin{tabular}{llll}
\hline & Coef. & Std. Err. & T \\
\hline P t-20 & 0.046 & 0.0033 & 13.73 \\
S t-10 & 0.032 & 0.0073 & 4.38 \\
U t-5 & 0.417 & 0.1003 & 4.16 \\
Cons & 0.273 & 0.1512 & 1.8 \\
\hline $\mathrm{R}==0.9644$ & $\mathrm{~F}=379.71$ & & \\
\hline \hline
\end{tabular}

According to the regression results, we can generate the equation below:

$$
A Y S=0.046 P_{T-20}+0.032 S_{T-10}+0.417 U_{T-5}+0.273
$$

\footnotetext{
${ }^{156}$ In the literature, the extrapolation can be used to project back the enrolment series. However, a modern school system in the Western sense was introduced in China only at the end of the $19^{\text {th }}$ century; this clear structure break in Chinese educational history around the turn of the $20^{\text {th }}$ century, invalidates the use of extrapolation to estimate enrolments before 1900 .

${ }^{157} \mathrm{We}$ have tried various combinations of lagged periods, and the results are quite similar.
} 
Table 3.5: Human capital accumulation in China (1920 -2000)

\begin{tabular}{lcccc}
\hline \multirow{2}{*}{ Year } & \multicolumn{2}{c}{ Population } & $\begin{array}{c}\text { AYS for } \\
\text { workforce }\end{array}$ & $\begin{array}{c}\text { Enrolment ratios } \\
(6-20)\end{array}$ \\
\cline { 2 - 3 } 1920 & Total & Workforce $(15-64) \%$ & 0.45 & 4.81 \\
1930 & 472 & 70 & 0.6 & 8.33 \\
1940 & 518.77 & 70.02 & 0.98 & 10.81 \\
1950 & 551.96 & 67.99 & 1.31 & 18.3 \\
1960 & 662.07 & 57.29 & 1.75 & 33.05 \\
1970 & 829.92 & 58.02 & 3.18 & 43.22 \\
1980 & 987.05 & 61.25 & 5.24 & 55.3 \\
1990 & 1143.33 & 64.97 & 6.25 & 56.76 \\
2000 & 1276.27 & 70.15 & 8.48 & 69.48 \\
\hline & & Growth Rate & (percent per year) & \\
1920-2000 & $\mathbf{1 . 2 5}$ & & $\mathbf{3 . 7 4}$ & $\mathbf{3 . 3 9}$ \\
$1920-1949$ & 0.52 & -0.36 & 3.63 & 4.55 \\
$1950-2000$ & 1.69 & -0.53 & 3.81 & 4.73 \\
$1950-1960$ & 1.84 & -0.92 & 2.91 & 6.09 \\
$1960-1970$ & 2.29 & 0.13 & 6.17 & 2.72 \\
$1970-1980$ & 1.75 & 0.54 & 5.14 & 2.5 \\
$1980-1990$ & 1.48 & 0.59 & 1.78 & 0.26 \\
$1990-2000$ & 1.11 & 0.77 & 3.09 & 2.04 \\
\hline
\end{tabular}

The estimated results on the educational stock of the workforce throughout $20^{\text {th }}$ century China are summarised in Table 3.6. The average years of schooling of the workforce progressed substantially between 1920 and 2000. The figure started at a very low level, 0.45 , and had risen to 8.52 in 2000 . The increase was about one year per decade, which yields a substantial annual rate of increase -- 3.74 percent per year. Through the first half of the $20^{\text {th }}$ century, educational stock rose slowly, from 0.45 years in 1920 to 1.12 years in 1948. During the first decade after the founding of Communist China, no impressive growth took place either. The educational stock stood at 1.14 at 1949 and had reached 1.53 by the end of the decade, an increase of only 0.39 years per decade. Rapid growth occurred only in the preceding couple of decades and the AYS increased sharply from 1.9 in 1960 to 8.48 in 2000 , with an increase of 1.65 years per decade. In regard to growth rate, the tipping point appears to be around 1970; even though it decelerated somewhat afterwards, it still remained at a high level. Given the fact that Chinese economic growth accelerated after 1978, it is consistent with what the literature 
suggests: that educational catching-up usually preceded rapid economic growth in the countries of East Asia(Behman \& Schneider, 1994; Dobson, 2013).

Furthermore, data for the period after 1958 allows us to calculate the average years of schooling of the working-age population, distinguishing different levels of education. According to Table 3.7, the increase in human capital stock was due largely to the 'primary school movement'. Even in 2000, half of the schooling received by the working-age population was composed of primary education. The share of secondary schooling rose rapidly after the 1970s, whereas the role of university and college level education remained marginal, occupying less than 3 percent of the years of schooling.

Table 3.6: Average schooling at different levels of education in China, $1950-2000$

\begin{tabular}{|c|c|c|c|c|c|c|c|}
\hline \multirow{2}{*}{ Year } & \multicolumn{4}{|c|}{ Average Years of Schooling } & \multicolumn{3}{|c|}{ Percentage (percent) } \\
\hline & Total & Primary & Secondary & Tertiary & Primary & Secondary & Tertiary \\
\hline 1920 & 0.45 & & & & & & \\
\hline 1930 & 0.6 & & & & & & \\
\hline 1940 & 0.98 & & & & & & \\
\hline 1950 & 1.31 & & & & & & \\
\hline 1960 & 1.75 & 1.38 & 0.29 & 0.07 & 19.35 & 1.88 & 0.46 \\
\hline 1970 & 3.18 & 2.35 & 0.75 & 0.08 & 33.94 & 5.62 & 0.54 \\
\hline 1980 & 5.24 & 3.3 & 1.82 & 0.12 & 41.58 & 14.89 & 0.79 \\
\hline 1990 & 6.25 & 3.6 & 2.47 & 0.19 & 46.82 & 20.78 & 1.19 \\
\hline 2000 & 8.48 & 4.7 & 3.33 & 0.46 & 50.34 & 25.98 & 2.81 \\
\hline
\end{tabular}

*Notes:

i. Average schooling refers to the average years of schooling for the working population.

ii. Primary schooling, provided for persons aged $6-12$ years

iii. Secondary schooling, provided for persons aged 12 -18years

iv. Tertiary schooling, provided for persons aged 18-24 years

In order to fully understand the growth trajectory of Chinese education attainment, we should make international comparisons. Figure 3.9 presents comparative data on the average years of schooling of the working-age population for several countries over the $20^{\text {th }}$ century. Drawing the data from Godo and Leewen, from the very beginning of the 20th century Japan remained the Asian front runner in terms of educational stock and its lead remained unchallenged over the entire $20^{\text {th }}$ century. The other Asian countries 
gradually converged with Japan; however, for Korea and Taiwan this convergence occurred much earlier and faster than it did for the bottom tier - China and India.

Figure 3.9 shows an intra-Asian divergence in terms of educational stock between 1920 and 1960. With a very similar educational level in 1920 to those of Taiwan and Korea, China then fell back, widening the distance to its Asian competitors. The acceleration in Taiwan and Korea between 1920 and 1950 can be partially explained by the enthusiastic promotion of mass education by the Japanese colonial government (Tsurumi, 1977). Only after 1960, did the growth rate in China begin to rise sharply; in the 1970s it surpassed India's average years of schooling and began to narrow the gap between it and the other countries of Asia.

Figure 3.9: International comparison of educational attainment 1920- 2000)

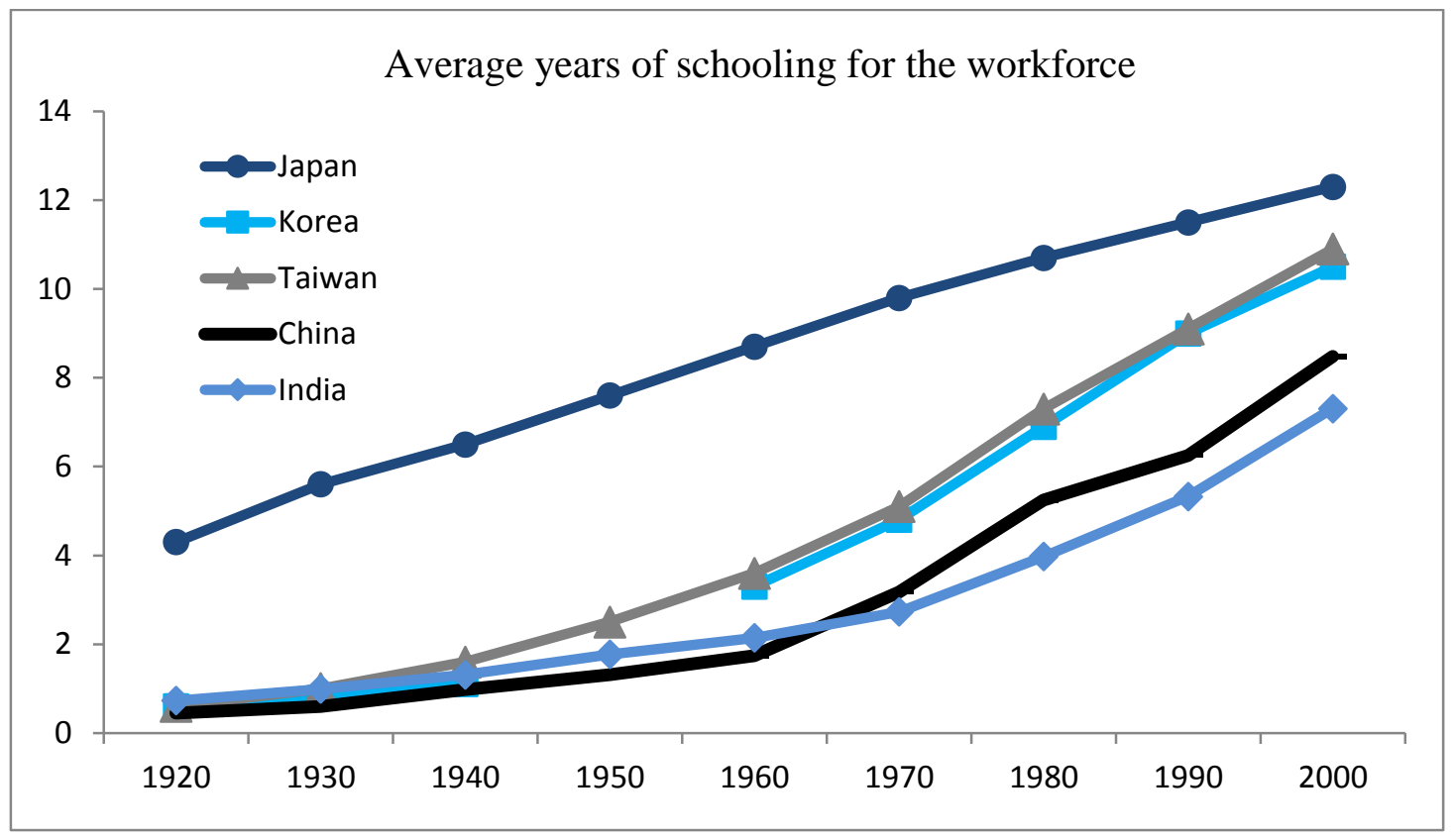

*Source:

i. Data for USA, Japan, Korea and Taiwan come from (Yoshihisa Godo, 2001; Yoshihiha Godo \& Hayami, 1999).

ii. Data for India are from (Leeuwen, 2007)

To further display how China's educational catching-up took place, we employ the results in Figure 3.10 with Japan's educational data as a benchmark to calculate the Japan/China gap at each level of education. China's educational attainment in 1920 was only 10 percent of that in Japan, but the ratio had risen to 60.3 percent by 2000 . We 
have seen a clear trend of convergence for both primary schooling and secondary schooling, but tertiary education, in contrast, took a long time to converge. In 1958, the average years of primary schooling, received by Chinese people was only 19 percent of that for their Japanese counterparts, but by 1995 the ratio had increased to 75 percent. Similarly, secondary schooling rose rapidly. In 1958, the Chinese received less than 1 percent of the years of secondary schooling that the Japanese had. The speed with which China caught up in secondary education accelerated rapidly after 1970 and in 2000, the Chinese got almost half the secondary education that Japanese received, showing considerable improvement. But the movement of the Japan/China ratio in tertiary education demonstrates that Chinese higher education caught up to only a limited extent over the $20^{\text {th }}$ century.

Figure 3.10: The China/Japan ratio in educational attainment by level of education

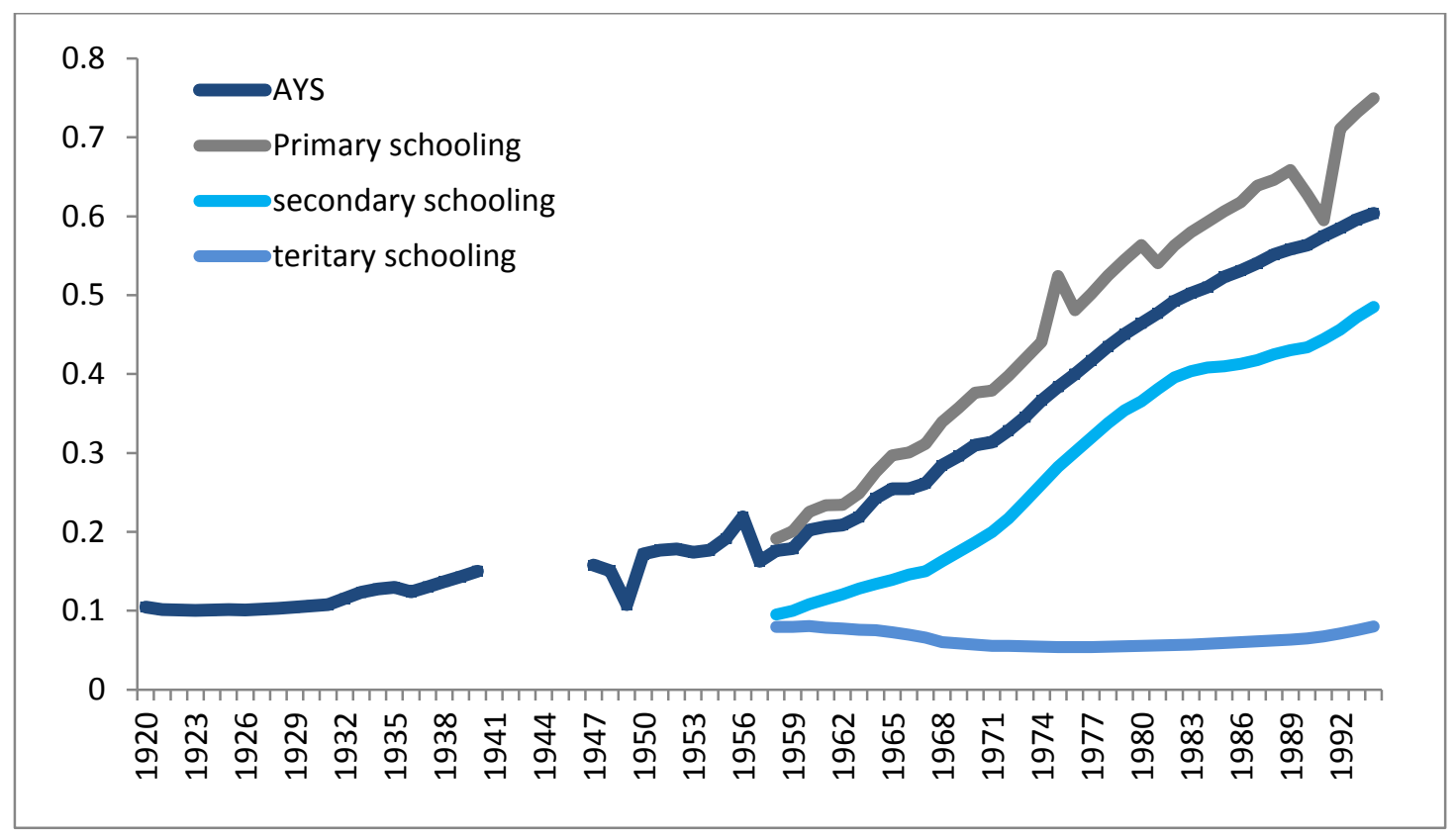

*Source: Data for Japan come from (Yoshihisa Godo, 2001; Yoshihiha Godo \& Hayami, 1999).

\subsection{Complementary evidence using individual survey data}

In this section, as a robustness check we use Chinese Household Income Project (CHIP) data from the first individual survey conducted in 1988 to provide complementary evidence to the previous estimations. ${ }^{158}$ At the same time, CHIP data provide much

158 Detailed information about the CHIP is available at the website http://www.icpsr.umich.edu/ICPSR/access/index.html (The Study No. for CHIP 1998 is 9836 and the Study No. for CHIP 1995 is 3012). 
richer information allowing us to explore other features of the growth of educational stock in China through the $20^{\text {th }}$ century.

The CHIP 1988 is the first national individual survey data asking questions about years of schooling and providing a sub-sample of the annual income and expenditure surveys of the Chinese State Statistical Bureau. Its questionnaire includes the question, 'How many years of schooling have you received?' The data contain two large samples (67,186 rural households and 34,945 urban households) drawn by the State Statistical Bureau (Griffin, Keith, \& Renwei, 1988). On the basis of CHIP 1988, we can roughly compute the outline of the years of schooling for different birth cohorts and, more importantly, we can examine gender disparities and urban-rural inequalities from the standpoint of educational attainment.

The main weakness of this dataset is that the size of its sample may be selectively small regarding old cohorts identified in 1988. Few people born between 1890 and 1900 were still alive in 1988. The CHIP 1988 incorporates 56,438 individual observations; however, the sample size for the 1890s birth cohorts consists of only 110, while for the 1900s birth group, the number is 489. At the same time, given that education is highly likely to be positively associated with the length of one's lifespan, the level of educational attainment for those early birth cohorts who were still alive in 1988 may be higher than the average for their generation.

\section{Gender inequality}

Figure 3.11 demonstrates the gender gap in terms of educational attainment through the $20^{\text {th }}$ century based on CHIP cohorts. Apparently, women and men shared the increase in education, but females gained more than males, in particular those who were born in the decades preceding the $20^{\text {th }}$ century and after the 1930s. The higher rate of growth of the educational stock for females is due to the initial gender inequality in education at the beginning of the $20^{\text {th }}$ century. This male-female inequality can partly be explained by the Confucian ideology, which confines women to a subordinate role in education. As pointed out in Chapter 1, one of the weaknesses of traditional Chinese education was its exclusion of females from the formal educational system. Even though the wide gap in education between males and females rapidly closed, taking only a few decades of 
modern educational expansion, the educational advantage for males did not disappear at any point throughout the $20^{\text {th }}$ century.

\section{Urban-rural gap}

Similarly, Figure 3.12 illustrates the urban-rural divide in educational development in China. People from both urban and rural settings shared the increase in educational attainment. However, the gap in years of schooling between rural and urban residents persisted throughout the whole period and remained between 4 and 6 years, which accounted for more than half of the average years of schooling received by the workforce. Such a marked urban-rural divide in educational attainment suggests that the educational expansion was not equally distributed across urban and rural areas and the failure to provide equal educational opportunities is still widely visible in present-day China. Moreover, the biggest disparity occurred for the 1920 birth cohort, who received education from around 1930 to 1950, implying that in the Republican era educational inequality was still noticeable. The huge urban-rural divide in education fits the features of educational decentralisation and the fact that modernisation and industrialisation were concentrated in a handful of regions, cities and treaty ports during the Republican period.

Figure 3.11: Years of schooling by birth cohort and gender

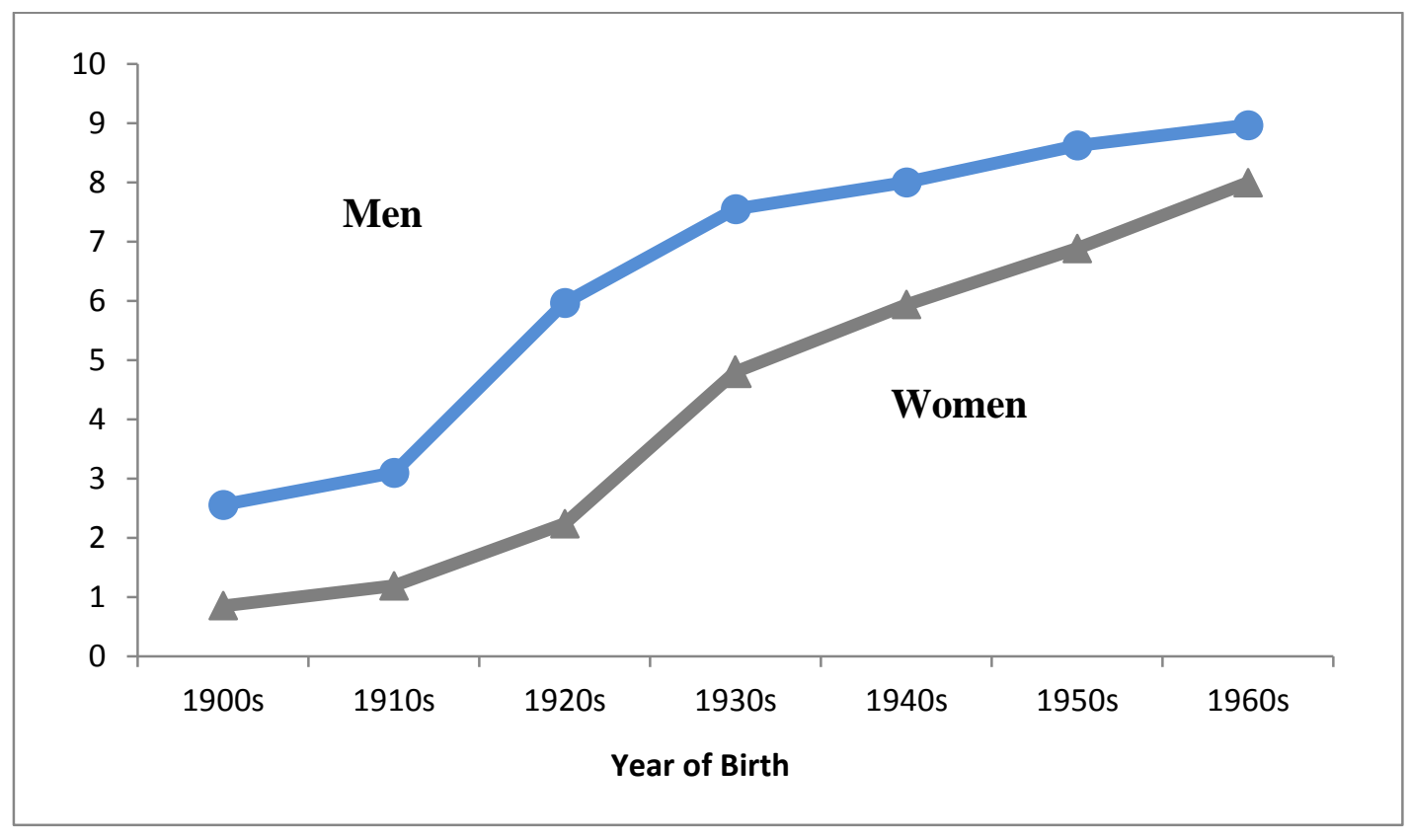

*Source: Chinese Household Income Project (CHIP) 1988 (Griffin et al., 1988) 
Figure 3.12 : Years of schooling by birth cohort and urban-rural divide

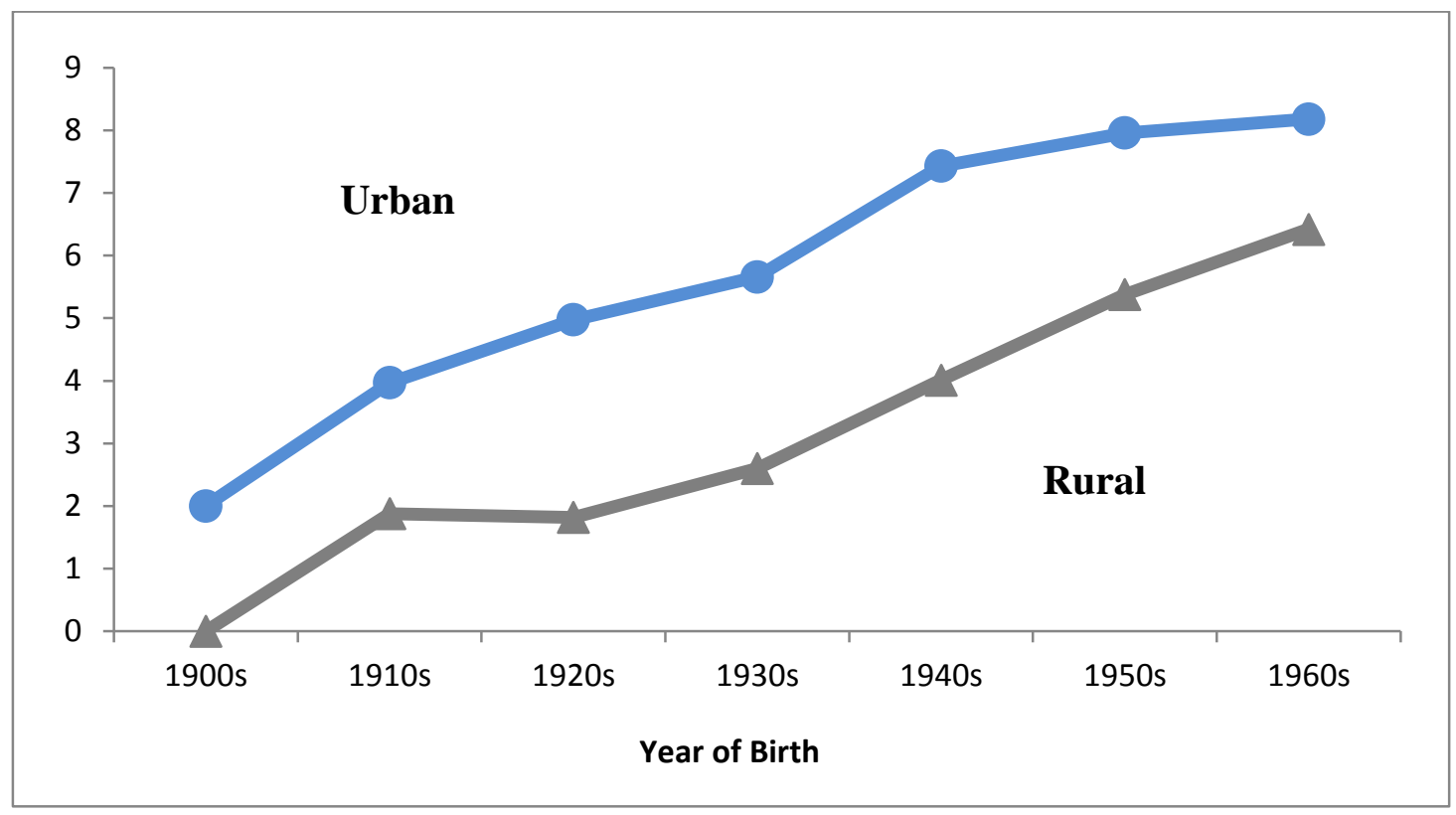

*Source: Chinese Household Income Project (CHIP) 1988 (Griffin et al., 1988)

\section{Re-examination: what did we miss?}

The CHIP data allow us to re-examine the previous results stemming from enrolment data, enabling us to compare the two results coming from two data tracks.

As discussed earlier, one major disadvantage lying in enrolment data is that it excludes the records of traditional schooling, as well as all other kinds of informal education. ${ }^{159}$ The average years of schooling that we obtain on the basis of formal school enrolment data, reflect only the amount of formal and modern education; however, the educational attainment series derived from CHIP data should capture all the kinds of education that people have received. ${ }^{160}$

Figure 3.13 shows that for the earlier generation, i.e. people born from the late 19th century to the 1920s, the gap between CHIP and enrolment is about one year. This missing 'one year' for Chinese people born between 1895 and 1913 may be explained as the traditional schooling that they received in Sishu, which cannot be counted in

\footnotetext{
${ }^{159}$ For instance, the informal education that people received in various forms of part-time schools and adult schools, which were very prevalent between 1950 and 1980, cannot be reflected in the enrolment series.

${ }^{160}$ The questionnaire in CHIP 1998 is designed in the form 'how many years of education have you received?' Answers to this kind of general question tend to include all the kinds of education that have been received.
} 
when we use government reported enrolment data. Additionally, the gap can also be caused by the older cohorts over-reporting their actual educational attainment.

\section{Figure 3.13: AYS stemming from enrolment data vs CHIP}

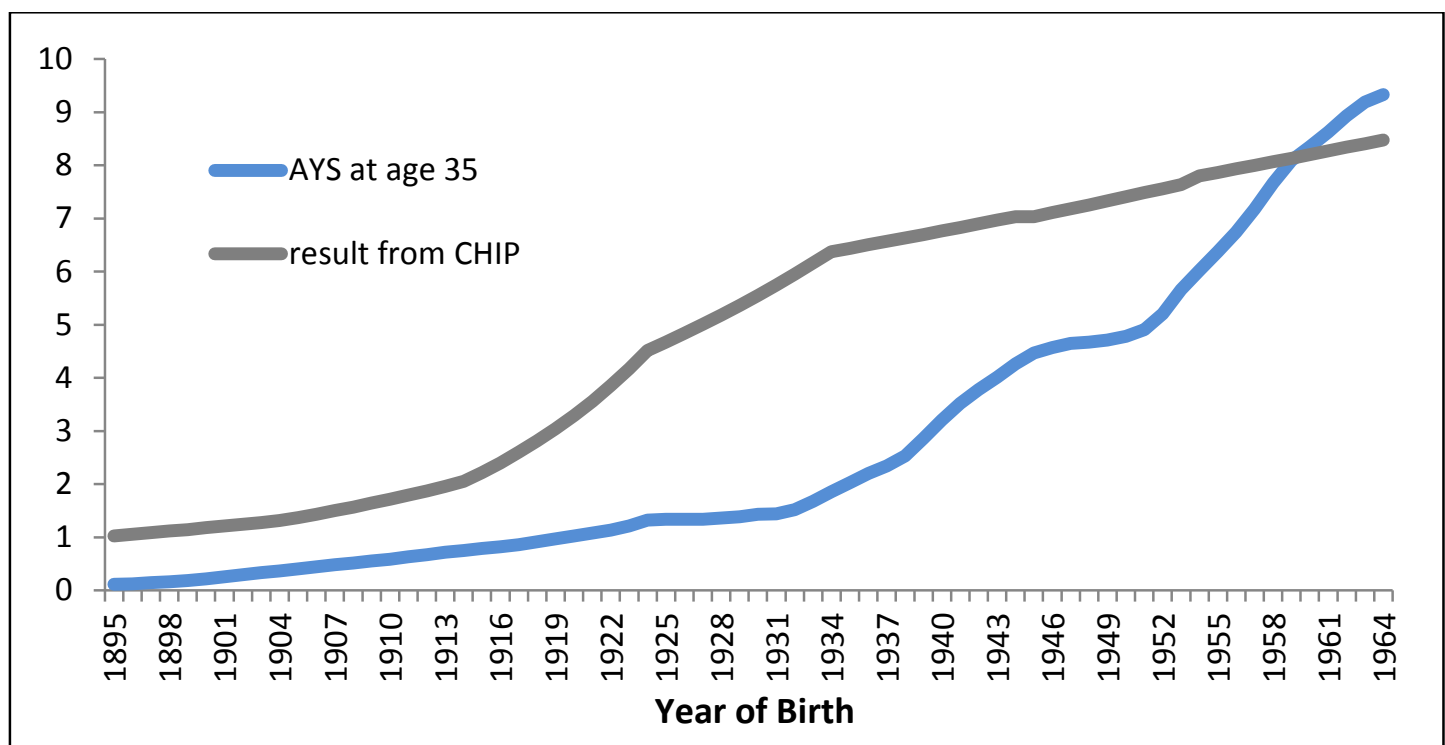

* Source:

1. AYS at age 35: using the Perpetual Inventory approach and based on enrolment data

2. Chinese Household Income Project (CHIP) 1988 (Griffin et al., 1988)

For the birth cohorts born between the 1920s and 1940s, the gap enlarged remarkably, implying that the informal schooling received by people born in this period increased significantly. Such increasing informal or adult education embodied in this age cohort can be attributed to their attending the massive campaign to eliminate illiteracy in the Mao period after reaching adulthood. Afterwards, the gap narrowed more gradually.

In short, educational attainment rose throughout the $20^{\text {th }}$ century, but the real acceleration began only from the 1960s. China gradually converged with its Asian competitors and after the 1970s even surpassed some, such as India. In terms of educational inequality, gender disparities remained severe, but narrowed over time. In contrast, differences in enrolment and attainment, by region and residence (rural or urban), remained strikingly high, partly due to the decentralisation of educational finance in the Republican period and partly because economic development itself was marked by regional inequalities in China, and this shifted the demand and supply of different types of education. 


\section{Concluding remarks}

This chapter used different measurements, alternative approaches and two datasets to assess the progress of education. The results are mixed when we consider flow variables. Changing patterns of literacy and numeracy rates indicate that China possessed a relatively high level of human capital as early as the turn of the $20^{\text {th }}$ century under the traditional education system; through subsequent decades, the literacy rate rose further, but modestly over time. The enrolment ratios for formal schooling paint a different picture revealing that at the beginning of the $20^{\text {th }}$ century China lagged badly behind in terms of schooling outcomes but bore the marks of a phenomenal educational expansion at the end of the Republic era and beyond. These different trends do not necessarily contradict each other, but are a reflection of the transformation of informal schooling to formal education. Under traditional education, a less defined schooling system and flexible teaching methods, it may have been possible to spread basic literacy to the masses. The remarkably increase in gross enrolment ratios suggest, however, wide acceptance for the diffusion of formal Westernized education when it was made available to Chinese children.

The result regarding educational attainment plots a slightly different trajectory, with little rise in the educational stock, as measured by average years of schooling, until the 1960s. The major contributor to the increase in human capital stock is the extensive spread of primary schools. Secondary schools expanded rapidly only after the 1980s and universities in the 1990s. Primary education expansion is mainly responsible for the rise of human capital in China through the 20th century.

In addition, based on the first individual level survey that included information on schooling, we are also able to discern the trends of the gender gap in educational stock, as well as the urban-rural inequality for the birth cohorts of the $20^{\text {th }}$ century. The estimates show that the gender gap closed up considerably, in particular for people born after the 1930s; while urban-rural disparities endured as the chief source of educational inequality in China. In the same vein, an intriguing gap between the results based on two tracks of data was observed, which presumably captures the amount of informal schooling received in the population. 
To put Chinese accomplishments in education into international perspective, at the beginning of the $20^{\text {th }}$ century, China lagged far behind most of the developed countries, whether measured by literacy rates, enrolment ratios or human capital stock. We also find evidence of China's catching up with its developing counterparts, including India and Brazil, through the first half of the $20^{\text {th }}$ century. However, the tipping points based on enrolment ratios and educational stock do not line up. The accelerating growth in enrolment ratios occurred much earlier, starting from the 1940s; while the catch-up for China, measured by educational stock, ensued only after 1960 . 


\section{Chapter 4 : Risen from Chaos: What drove the spread of Modern Primary Schooling in China in the early 20th century}

Universal access to primary education is a social policy that spread quickly from the nations of Europe to the US in the nineteenth century and later to Asia. In China, the attempt to provide mass schooling was part of a greater agenda to establish a modern and Western-inspired education system at the dawn of the $20^{\text {th }}$ century.

Why and how did mass schooling in China rise when it did? In order to look into its determinants through the opening stages of its development, this chapter for three reasons focuses on primary education. First, at this stage, universal education in China targeted primary schooling alone. ${ }^{161}$ Second, according to the calculations in Chapter Three, the average years of schooling of the Chinese workforce in the 1940s reached only around two years, with almost all its education throughout this period received from attending primary schools. Last but not least, of all levels of education, primary schooling has been shown to have its most positive effect during the early stages of industrialisation; the rates of return in late industrial nations are generally believed to be higher for primary schooling than for further education (Psacharopoulos, 1981; Psacharopoulos \& Patrions, 2004).

A growing body of literature has focused on identifying the determinants of educational expansion (Beltran Tapia, 2013; Chaudhary, 2009; Gallego, 2010; Go \& Park, 2012; Goldin \& Katz, 2008; Lindert, 2004a; Lindert \& Go, 2010; Musacchio, Fritscher, \& Viarengo, 2014). What makes China's historical path particularly interesting? First, given that most existing studies concentrate on investigating OECD countries or former colonies, the case of China in the early $20^{\text {th }}$ century would enrich the literature by increasing our understanding of what drives the rise of education in societies setting out in very different economic and political conditions from those of

\footnotetext{
161 The Education Act (1904) referred to primary education as mass schooling, and in 1915, the state officially made lower-primary schooling compulsory (F. Wang, 1994, pp. 460-468). However, the requirement of providing compulsory lower-primary schooling was without doubt too ambitious in China's economic and political circumstances, so the actual implementation of such legislation was never wholly successful.
} 
the developed world. Moreover, it is always an empirical challenge to disentangle the effects of supply and demand in schooling. With a distinctly new education system, China's sudden and substantial change in education quality and quantity through the first half of the $20^{\text {th }}$ century was arguably an exogenous supply shock. This experience provides a good testing ground for sorting out the contributing factors in the increasing supply of mass education, subject to some data limitations of pre-1950 China.

This chapter reveals that a critical role was played by the informal practices of governance imposed by one of the most important social groups in the history of China, namely the gentry. The local gentry, most of whom passed the civil service examination with a lower degree, supported the expansion of modern education because of their enduring public obligatory responsibility to local education, and their private interest in modern schooling as a potential source of income. Equally importantly, Mancur Olson's story of roving bandit is applicable in the context of China, in that we find the pattern of political stability bred better governance (in terms of schooling provision), and the positive effect of the local gentry was also enlarged in regions exposed to more unstable politics.

The findings of this chapter are exceptionally important. First, it notes an interesting contrast with the early stages of educational development in Europe, where the landholding elites were seen as the main interest group blocking the provision of education to people of lower rank(Cressy, 2006; Kaestle, 1976; Lindert, 2004a, pp. 100-104). In addition, as the local gentry's status was granted via traditional education, this finding confirms the legacy of traditional education in fostering the rise of modern schooling, which has been neglected in the field of Chinese educational history. Lastly, this research sheds light on the growing literature stressing the importance of informal institutions enforced by social groups as providers of public goods in non-democratic societies (Helmke \& Levitsky, 2004; Sklar, 2004; Tsai, 2007; Yinqing Xu \& Yao, 2014, Forthcoming).

The rest of this chapter is organised as follows. First, a conceptual framework is presented alongside the existing literature on factors contributing educational 
provision. Then, a brief introduction of the first modern primary education system in China is set out in section 2. Section 3 provides a politico-economic framework to explain the regional variations in schooling, in which the intentions and incentives of several key interest groups are identified. Finally, new archival data is used to conduct a series of empirical tests. The results are consistent with our conjecture: economic factors have limited power to explain the dispersion of schooling variables, whereas political stability and the strength of local elites contributed more to the successful diffusion of modern primary education in China throughout the early $20^{\text {th }}$ century.

\section{Conceptual framework: what are the driving forces of education?}

Schooling outcomes are determined by the supply and demand of education. On the demand side, more children can be attracted to school either by reducing the cost of education or by increasing the return attached to it. However, global evidence suggests that for basic education in particular, educational provision, especially through a public initiative, is vital. This is because publicly supplied education can reduce the cost of education to such an extent that receiving it becomes affordable for the first time to most of the population. Many cross-sectional studies confirm this claim (Hanushek \& Woessmann, 2011). Therefore, in examining the expansion of mass schooling in China through the early $20^{\text {th }}$ century, this chapter focuses mainly on the supply of education provided throughout this period.

\subsection{Explaining supply}

"Mass schooling did not arise spontaneously from popular demand or from the action of market forces alone. It was to a large degree organised from above by the state." (Green, 1990, p. 297).

Bearing in mind the predominant importance of the supply of schooling in the expansion of mass education, our focus begins with the factors that contributed to education provision. Supplying education is a public decision; and public schools dominate the history of educational expansion. The literature from other countries indicates that economic prosperity, the commitment of the government, and the 
homogeneity of local communities most powerfully explain the rise of educational spending (Gallego, 2010; Goldin \& Katz, 2008; Lindert, 2004a).

\subsubsection{Economic factors on the supply side}

The relationship between economic development and education remains unclear in the literature. Cross-sectional studies show that public efforts in mass schooling provision increase with the level of economic development (Frenandez \& Rogerson, 2001; Lindert, 2004b; Lott, 1990a; Mitch, 2013), because economic prosperity generates higher tax revenue for the government and wealth for households, both of which are positively associated with schooling provision and enrolment ratios.

\subsubsection{Government commitment}

Politics largely shape the level of government commitment to education and the procedures for implementing education policies. Previous research shows that the two major definitive actors in this area are the type of political regime and the extent of administrative decentralisation. ${ }^{162}$ More importantly, different combinations of these two factors generate different outcomes.

\section{1). Decentralized education system in democratic societies: local elections as enforcement}

Educational outcomes seem to be positive when high political participation is combined with administrative decentralisation. As discussed in Chapter One, it is widely agreed that that broad-franchise democracies tend to provide more public education than elite-franchise democracies, because universal education is essential for keeping the election procedure in operation, allowing the poor to be more politically active and enhancing the capacity of citizens to make good 'electoral decisions' (Castelló-Climent, 2008; Freire, 1976; West, 1965, pp. 40-49). In the same vein, many authors further develop the idea that local democracy amplifies the

\footnotetext{
162 The decentralisation of education does not stand by itself as a predictor of whether it facilitates or suppresses the development of education. There are several advantages of a decentralised education system, the two essential ones lying in the improvement of financial and administrative efficiency, which could lead to the same level of resources being allocated to higher education (Goldin, 1998; Lindert, 2004a; Mitch, 2013). For instance, limited revenues could be spent more wisely and monitored more closely; however, regional attainment levels could vary substantially under such a regime.
} 
advantages of a decentralised education system, because when educational decisions are delegated to local residents, voters tend to raise funds by taxing themselves to promote the education of their own children (Campante \& Chor, 2012; Cappeli, 2014; Gallego, 2010; Goldin \& Katz, 2009; Lindert \& Go, 2010).

\section{2). Decentralized education system in non-democratic societies: Problems of enforcement when formal institution is weak ${ }^{163}$}

By contrast, when control of education is decentralized in authoritarian regimes, schooling outcomes can be ambiguous. Under such a political system, local officials naturally have no democratic accountability to local residents. Thus, the decisionmaking process is not determined by the popular will of local residents, but rather by the political dynamics - the equilibrium achieved between the preferences of various veto interest groups.

In most of cases, developing countries are equipped with weak formal administrations to enforce benevolent governance. The way in which mass education progress was encouraged or hindered in developing countries, where the political and economic conditions differ from those in developed economies, have been illuminated in recent empirical studies(Chaudhary, 2009; Chaudhary et al., 2012; Go \& Park, 2012; Musacchio et al., 2014). These studies all point to one fact: when formal institutions fail to provide accountability to the populace, the nature of the political elites is the key factor in explaining the amount of education provision.

In short, it is informal rules, usually enforced by important social groups, to implement public policy in societies where formal democratic and bureaucratic institutions are weak. This process can lead to high levels of corruption and local predation, as commonly witnessed in Latin America, Central Asia and Africa

\footnotetext{
${ }^{163}$ Formal institution is not necessarily weak in non-democratic socities. Local officials can be strongly incentivised to deliver good governance, including promoting mass education; when official's career prospects is closely tied to achieving the 'right' goals set up by superiors. For instance, a reward mechanism, placing economic growth as the central criteria for local official's career advancement, substantially contribute to China's economic development after 1978(Hongbin Li \& Zhou, 2005; Shih, Adolph, \& Liu, 2012). Unfortunately, a strong personnel control system plus setting up the 'right' goals for the officials to attain is not a common scenario can be observed in most of non-democratic countries.
} 
(Collins, 2003; O'Donnell, 1996). Nonetheless, more and more evidence points out that informal institutions can also bring about benevolent governance, in particular when the informal institutions encourage collective action in the financing of public goods. In the Chinese context, informal rules created by social groups, for instance, with regard to lineage, have been found to be accountable for the local provision of public goods, including education, in China even today (Tsai, 2007; Yinqing Xu \& Yao, 2014, Forthcoming). ${ }^{164}$

\subsection{China's exogenous education supply shock in the early $20^{\text {th }}$ century}

Even though we stress the role of supply in education expansion for societies in the early stages of development, the demand for schooling also matters. In fact, it can be difficult empirically to separate the impacts of demand and supply.

However, a remarkable change in the provision of education within a short period could arguably be considered as an exogenous supply shock. At the turn of the $20^{\text {th }}$ century, China's distinctive new education system provided a sudden and substantial change in the quality and quantity of education. The number of primary schools was only 173 in 1902, but grew by 1850-fold in the next few decades, to 320,086 in 1936 . At the same time, the 'quality' of education also changed radically under the commands of the state. ${ }^{165}$ Such a dramatic sudden change in education within a short term window can be seen as an exogenous supply shock. Therefore, early $20^{\text {th }}$ century China is a suitable empirical testing ground for understanding what drives the rise and provision of mass education.

\footnotetext{
164 The damage to traditional social groups, such as those formed by lineage and gentry, through the Cultural Revolution period was devastating. But social groups have continued to play a major role in providing public goods in today's China. To some extent, it suggests a heavy inertia and marked power of resistance to change among traditional social groups in Chinese culture.

${ }^{165}$ Here, 'quality of education' does not indicate the teacher-student ratio or school improvements in facilities; rather it refers mainly to the fact that the content of education went through radical change during this period. Whether the change of curriculum was good or bad is not the central focus of this chapter, but at least it is clear that the content of education changed dramatically.
} 


\section{Historical Background: the new primary schooling system}

This section briefly sets out several key features of China's primary education system. As pointed out in Chapter Two, the primary schooling system had two principal features: the dominance of public over private schools, and the highly decentralised design. The following sections elaborate on these two features.

Figure 4.1: Primary Schools by Management

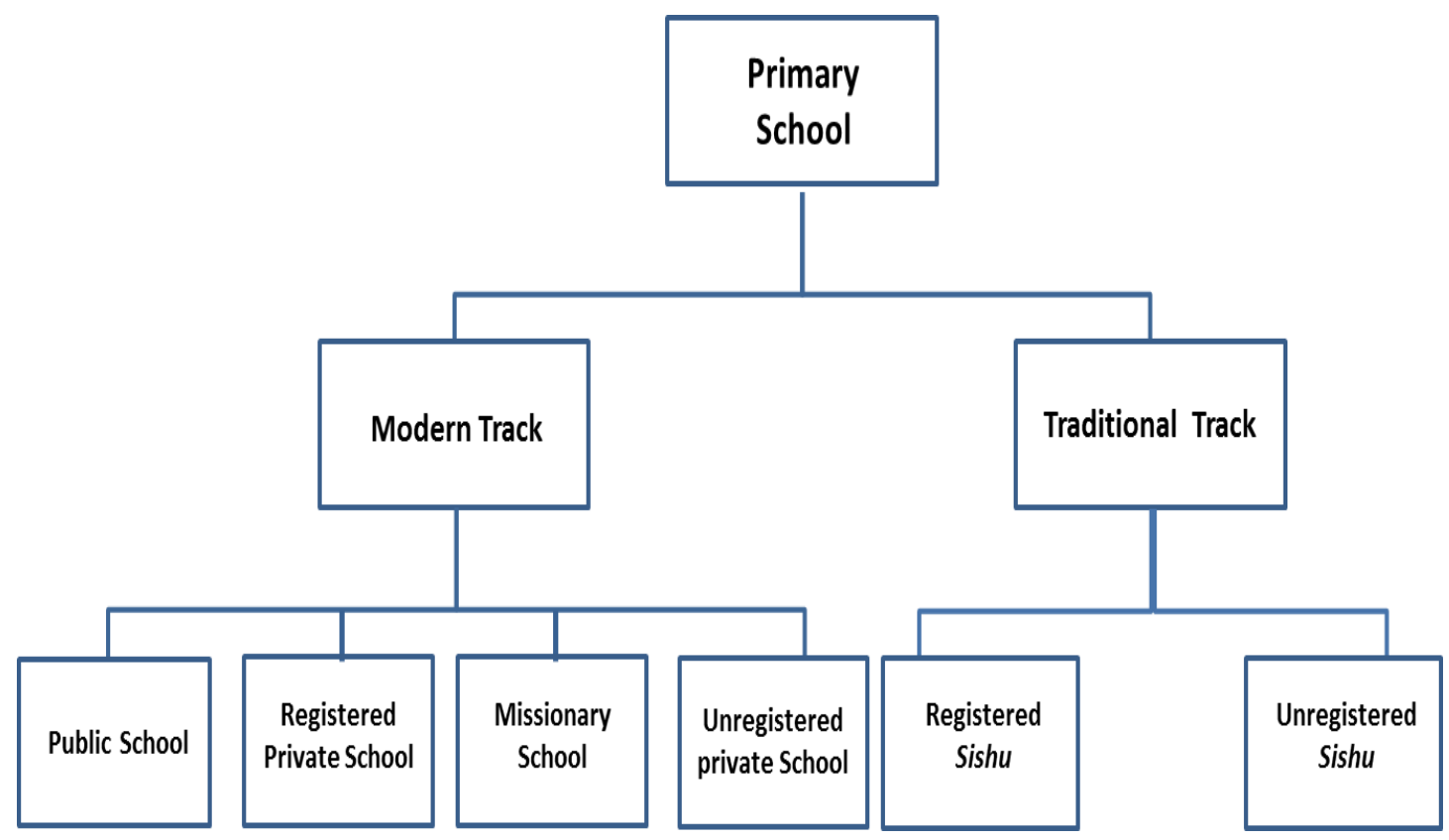

Many types of educational institution coexisted and delivered similar primary education to children throughout this period. They are broadly categorised as public primary schools, registered private primary schools, non-registered private schools, missionary primary schools ${ }^{166}$ and traditional primary schools - sish $u^{167}$ in Figure 4.1. But because this research focuses on the rise of modern schooling, the sishu, as part of traditional education, lies beyond its scope. Unregistered private schools and missionary schools are also excluded, because the former hold no statistical history, and the success of the latter cannot be attributed to the efforts of the Chinese state. Thus, the data under discussion include only public and registered

${ }^{166}$ Data on missionary schooling are included in the regression section to indicate the penetration of Western culture, but are not assessed here in relation to education progress in China.

${ }^{167}$ As discussed in previous chapters, after the termination of the Civil Service examination, Sishu continued to provide basic literacy and numeracy to children; thus, they were quasi-primary schools. Unfortunately, the Republican government discontinued Sishu in the formal schooling system. 
private primary schools, which, as is shown below, accounted for the majority of educational institutions in the category of modern primary schooling.

\subsection{Primary education in context}

Both the declining Qing Court and its successors showed a marked intention to pursue the development of a public and funded education system, with particular focus on the primary school sector. The second important feature of the modern primary education system lay in its highly decentralised design - the decision-making authority was concentrated within government at the county level. ${ }^{168}$ As discussed in Chapter Two, the first Education Act of 1904 had already outlined clear regulations regarding the allocation of responsibility for each level of education: central government undertook to deliver tertiary education; secondary schooling was delegated to provincial governments; and primary schooling to county and sub-county authorities (Huaxing Li, 1997, pp. 533-538). In this new system, accordingly, as the degree of decentralisation increased downwards through the schooling levels, primary education was the most decentralised.

Table 4.1: Composition of public primary schools (\%) ${ }^{169}$

\begin{tabular}{|c|c|c|c|c|}
\hline \multirow{2}{*}{ Year } & \multicolumn{4}{|c|}{ Public Primary Schools } \\
\cline { 2 - 5 } & \multirow{2}{*}{ National } & \multirow{2}{*}{ Provincial } & \multicolumn{2}{|c|}{ Local } \\
\cline { 4 - 5 } & & & County & Sub-county \\
\hline 1916 & 0.03 & & 74.07 \\
\hline 1930 & 0.01 & 0.61 & 26.45 & 48.49 \\
\hline 1933 & 0.01 & 0.62 & 17.26 & 64.12 \\
\hline 1940 & 0.01 & 0.16 & 47.49 & 45.47 \\
\hline 1946 & 0.02 & 0.14 & \multicolumn{3}{|c|}{94.1} \\
\hline
\end{tabular}

*Sources: same as the Figure 2.1

\footnotetext{
168 The term 'local government' in this research refers to county government and sub-county governing bodies.

${ }^{169}$ As pointed out in Chapter Two, the classifications in Tables 4.1 and 4.2 relate to the authority in administrative control and to ownership, but not to sources of revenue. For instance, 'public school' in this chapter refers to schools that are publicly provided, but not necessarily fully reliant on public funding. Similarly, to put a school in the provincial category does not necessarily indicate that it was entirely financed by the provincial budget. It might have been subsidized by the central government and private donations.
} 
As shown in Tables 4.1 and 4.2, local primary schools (county and sub-county government) accounted for the largest proportion. Throughout the whole period, the percentage of national and provincially administered primary schools never reached more than $1 \%$ of the total of primary schools, which reflects the marginal role that central and provincial governments played in the spread of such schooling. ${ }^{170} \mathrm{In}$ contrast, the share of local primary schools stood at about $75 \%$ in 1930, and the figure continued to increase over time, reaching $94.1 \%$ in 1946 . This breakdown of data is consistent with the educational regulation that the task of diffusing modern primary education should fall mainly on local governments.

Table 4.2: Composition of public primary schools by province in $1933(\%)$

\begin{tabular}{lcclll}
\hline & National \& & County & District & Township & Others \\
& Provincial & \&unicipal & & & \\
\hline ALL & $\mathbf{0 . 6 2}$ & $\mathbf{1 6 . 9 8}$ & $\mathbf{2 6 . 3 8}$ & $\mathbf{3 4 . 5}$ & $\mathbf{3 . 9 7}$ \\
Zhili & 0.11 & 14.84 & 5.85 & 74.01 & 2.69 \\
Henan & 0.14 & 15.55 & 28.1 & 47.7 & 3.69 \\
Shanxi & 0.13 & 3.29 & 0.5 & 93.2 & 2.31 \\
Shandong & 0.17 & 8.34 & 26.28 & 51.27 & 11.38 \\
Shaanxi & 0.18 & 16.85 & 16.55 & 35.33 & 10.8 \\
Gansu & 0.82 & 34.06 & 54.16 & 2.67 & 1.23 \\
Jiangsu & 0.44 & 88.41 & 2.32 & 2.43 & 0 \\
Anhui & 1.11 & 37.74 & 38.08 & 1.57 & 0.31 \\
Jiangxi & 1.15 & 13.51 & 16.69 & 18.28 & 6.09 \\
Fujian & 1.06 & 22.41 & 39.22 & 0 & 0 \\
Zhejiang & 0.21 & 6.6 & 44 & 8.48 & 0.7 \\
Guangdon & 0.06 & 3.27 & 13.95 & 18.61 & 0.9 \\
Guangxi & 0.05 & 5.52 & 90.21 & 0 & 0 \\
Hubei & 4.34 & 28.78 & 18.67 & 4.87 & 1.08 \\
Hunan & 0.04 & 1.94 & 48.42 & 12.32 & 2.07 \\
Yunnan & 0.11 & 6.59 & 53.27 & 33.63 & 3.45 \\
Guizhou & 0 & 62.36 & 16.65 & 5.34 & 1.63 \\
\hline
\end{tabular}

*Source:
(i).Department of Education, Quanguo Jiaoyu Jingfei Tongji 1932-1933 (The national educational finance report 1932-1933), 1937

(ii). Department of Education, Quanguo Chudeng Jiaoyu Tongji (The statistical report on primary education), 1934

\footnotetext{
170 The only exception is the province of Hubei, which in 1931 reported 204 provincial primary schools, accounting for $5 \%$ of the total number, which is much higher than the national average. The abnormally high involvement in primary education of the Hubei provincial government is not only the legacy of the personal commitment to modern education of the former Viceroy of Huguang, Zhang Zhidong; it is also because in 1928, Hankou's 'Special Municipality' status was removed, leading to its merger under Hubei province. The Hubei provincial government took over all the primary schools in Hankou city originally founded by the municipality, and these were counted as provincial primary schools.
} 
For the year 1933, explicit information is found on the ownership of primary schools. In Table 4.2, we see that except for a small number of provinces, the largest driver for the rise of public primary education was not the support of county governments, but rather local communities (at district and township levels). Around 64\% of primary schools in 1933 were provided by small local communities that did not even count as legitimate state organs, which further proves the great extent of decentralisation in primary education in this period.

\subsection{Financing primary schools}

A rapidly expanding modern primary schooling system requires extensive funding. This section moves to one of the most critical questions: how the increasing number of modern primary schools was financed throughout the first half of the $20^{\text {th }}$ century. The system was a patchwork of financing. In general, restrained by resources, different types of primary schools relied on various sources of revenue (Chauncey, 1992; Ven, 2005).

Table 4.3: The difference between provincial, local and private schools

\begin{tabular}{|l|c|c|c|c|c|c|}
\hline \multirow{2}{*}{ Year } & \multicolumn{3}{|c|}{ Students per school } & \multicolumn{3}{c|}{ Expenditure per student(Yuan) } \\
\cline { 2 - 7 } & Provincial & Local & Private & Provincial & Local & Private \\
\hline 1916 & 205.33 & 33.91 & 27.46 & 27.70 & 6.35 & 22.22 \\
\hline 1933 & 163.98 & 44.78 & 52.81 & 28.54 & 7.74 & 10.01 \\
\hline $1940^{171}$ & 383.40 & 112.54 & 128.68 & 21.16 & 6.57 & 7.33 \\
\hline $1946^{172}$ & 359.68 & 57.65 & 125.14 & 207371.83 & 24727.31 & 20833.45 \\
\hline
\end{tabular}

*Sources:

(i). 1916: (Zhonghua minguo jiaoyu tongji tubiao (The education statistic report for Republic of China, fifth) 1916)

(ii). 1933: (Quanguo Chudeng Jiaoyu Tongji (The statistic report on primary education) 1934)

(iii).1940: (Quanguo Jiaoyu Tongji ( The national education statistic report ), 1940)

(iv). 1946: (Zhu, 1948)

171 The 1940 educational yearbook covers only nine provinces.

172 The high expenditure per student in 1946 was due to the soaring inflation rate. 


\subsubsection{Provincial primary schools:}

In principle, the provincial department of education managed the funding for a handful of provincial primary schools directly from provincial budgets. These schools were few, accounting for less than $1 \%$ of the primary schools in this period. In fact, most were higher-primary schools attached to provincial secondary schools, and located in the provincial capitals or prefectural seats. They enjoyed more adequate and stable sources of revenue, and were well-built and better equipped, which allowed them to accommodate a large number of students; some of whom may have had to travel some distance.

\subsubsection{Local primary schools}

The overwhelming majority of modern primary schools were local, registered under the county or even local communities, which often faced severe fiscal constraints. Their budgets could not draw on one revenue source alone; instead they had to be met through a combination of funds from various sources: local surtaxes, rent from public land, and donations from local wealthy residents, as well as parental contributions (tuition fees).

In contrast to the grander and more expensive provincial primary schools, local primary schools were modest. On average, local primary school taught about 50 pupils in all, and the spending for each student was only one quarter of the amount spent on each student at a provincial school. In line with such principle of austerity, local primary schools are often recorded as occupying the older property of a traditional academy that was renovated to form a new schoolhouse. Sometimes Buddhist temples and traditional Tangs where local people worshipped their ancestors were confiscated and furnished as modern primary schools (Gamble \& Burgess, 1921, p. 130). The condition of schoolhouses was so modest that they often lacked on-site toilets (Liao, 1936, p. 69). ${ }^{173}$

In order to shed more light on how local primary schools raised funds, more than 400 available county government balance sheets on educational finance in the 1930s were drawn on for this research. As Table 4.4 shows, the county budget for primary

\footnotetext{
173 This adverse condition directly led to reluctance among female students to attend primary schools, which severely affected the enrolment ratios for girls.
} 
education came from two main sources: surtax (mainly on land) and revenues generated from endowed school land.

Table 4.4: The revenue composition for primary education at county level (Yuan)

\begin{tabular}{lcccccc}
\hline & All & Hubei & Shandong & Henan & Zhili & Jiangsu \\
\hline Various surcharges & $\mathbf{6 3 . 7}$ & 41.49 & 70.4 & 76.7 & 59.62 & 70.29 \\
surcharges on land tax & $\mathbf{4 0 . 6 1}$ & 21.94 & 62.3 & 51.8 & 26.43 & \\
Endowed school land & $\mathbf{1 7 . 8}$ & 43.51 & 12.9 & 16.33 & 8.53 & 8.19 \\
& & & & & & \\
\hline
\end{tabular}

*Note: As in table 2.9, this table presents information for the provinces of Hubei, Zhili, Jiangsu, Shandong and Henan, 423 counties in total.

*Source: See Table 2.9

\section{1). Non-statutory revenues: the main revenue source of local primary schools}

Tax revenues were the main source of the funding for setting up and maintaining the public primary education system. Table 4.4 shows that revenues from various types of surcharges accounted for more than $60 \%$ of the budget, constituting the primary element in the county budget for education. However, according to the Chinese fiscal system laid out in Chapter Two, county governments had no official fiscal capacity to retain most of these tax revenues for local use. ${ }^{174}$ Therefore, these surtaxes, that local governments relied on to build up modern schools, can be regarded as non-statutory revenues.

According to both historical narratives and the available county balance sheets, it is abundantly clear that fiscally-stressed local governments resorted to informal practices to raise funds throughout this period. They levied various surtaxes and other

\footnotetext{
${ }^{174}$ As pointed out in section 4.1 of Chapter Two, county governments were officially equipped with minimum fiscal capacity to facilitate the financing of primary education. Under Qing rule, county government collected taxes only on behalf of the state, and had to remit most of the tax revenue to the province. They were allowed to retain only a small proportion for standard local administrative expenditure, including wages for officials and necessary expenditure on ritual ceremonies (Marianne, 1985; Remick, 2004, pp. 32-34; D. Zelin, 1984, pp. 26-62). Entering the Republican era, there was still no separate source of tax revenue below provincial level (C. S. Li, 1922, pp. 701-791), and consequently, no fundamental improvement could be made in the counties' fiscal capacity (C. S. Li, 1922, pp. 701-791; Remick, 2004, pp. 35-39). Because of the way that tax revenues were divided, county governments were habitually strapped for cash.
} 
forms of commercial fees from residents to fund local projects, including local primary schools(Chauncey, 1992; S. Liu, 1935; Remick, 2004, pp. 37-39; Sun, 1935; Y.-c. Wang, 1973), despite the fact that they were not given legal fiscal capacity to levy new levies. ${ }^{175}$

The central state made great efforts to consolidate the excessive local taxes after the collapse of the Qing dynasty. ${ }^{176}$ For instance, the Beiyang government strictly stipulated that land surcharges had to be lower than $30 \%$ of the base tax (Sun, 1935, p. 187). Similarly, the Nanjing government continued to launch edicts, and specified that the total amount of surcharges must not exceed the base tax (Sun, 1935, p. 124). However, in practice taxation was well beyond control. Throughout the first few decades of the $20^{\text {th }}$ century, increasing varieties of surcharges on land tax were enforced, and the tax rates of these newly issued items skyrocketed, far exceeding what the state regulated. According to contemporary documentation, as many as 673 new items were taxed, which made the systematic management of land tax an impossibility (S. Liu, 1935, p. 187; Sun, 1935, pp. 213-217). ${ }^{177}$ Another method to regulate tax revenues for primary schooling was to grant local governments the authority to institute 'educational launches'. This term refers to tax revenues that were reserved by government regulations for the support of schooling. However, the edicts on educational launches differed significantly between provinces; the launches mostly failed after a very short period of relief for local government (Du \& Yang, 1934). ${ }^{178}$

\footnotetext{
${ }^{175}$ Regarding the fiscal system of China through this period, please refer to eh section 4.1 of Chapter Two. Briefly, county government should only work as a state agent in tax collection, and they had no right to retain large amount of tax revenue for local use without remitting back to central, no alone levying new tax items without upper government's permission.

${ }^{176}$ The common practice of charging permissible surtax for local projects was partly endorsed by the Qing regime because of increasing special local needs and the state's weakness. Shandong and Zhili provinces first began to allow local governments to levy surcharges on land tax for local flood control and famine relief after the severe flooding of the Yellow River in 1903; these opened the door to surcharges on the land tax, which then became prevalent across China. e

${ }^{177}$ For instance, comparing the level before the state's collapse, the surcharges on land tax increased by 86 times in Hubei in 1934, 9.5 times in Jiangxi, and occasionally three times higher than the base tax in Sichuan and Jiangsu (Sheridan, 1977, pp. 203-205). Not only had the amount of surcharging skyrocketed, but also their variety had increased substantially. In Jiangsu province, more than 147 kinds of surcharge were enforced on the base tax for local use between 1912 and the 1930s.

${ }^{178}$ For instance in Jiangsu, before 1913, salt (lijin) and transportation surcharges were reserved by law for educational expenditure. Later, an animal slaughter tax, a brokerage tax, and surcharges on rice, were set aside as educational launches (Du \& Yang, 1934). In Shaanxi province, such launches included a slaughter tax and a cotton tax. In Yunnan province, the tobacco tax revenue was devoted to education (The education finance of Yunnan province 1933, p. 42).
} 
In short, consistent with the historical literature, we find direct evidence that surcharges, land tax in particular, were the dominant source of education revenue for local primary schools. In the 1930s, according to our sample, nearly $65 \%$ of educational revenues came from the tax surcharges in the county budget. Moreover, this figure was noticeably higher in rich agricultural provinces, for instance, Shandong and Jiangsu. Thus, non-statutory revenues predominated as sources of funding for primary education development at county level.

\section{2). Historical legacy: the importance of endowed school land}

Another important contribution to public primary school financing came from the rents earned from community-owned school land, which had been endowed to support traditional academies. ${ }^{179}$ In Table 4.4 , our sample shows that $17.8 \%$ of educational expenditure in the 1930s came from the rents of endowed school land. In the same vein, a micro-study of Ding county during the Republican era finds that the operations of $47 \%$ of the county's primary schools depended on rents from school-owned land to some extent(Gamble, 1954, pp. 200-201).

Under Imperial rule, endowed school lands were owned by traditional academies which, as mentioned in the previous chapter, were publicly-provided higher education institutions for prospective examination candidates. When the schoolhouses of traditional academies were converted to modern primary schools, these emerging new schools also inherited their long-lasting source of revenue, i.e. endowed school land.

The amount of school land was largely controlled by one measure: the size of the county/prefectural academy, which was determined by a quota system regulating the number of successful candidates who could pass the first level of the exam (the licensing exam). ${ }^{180}$ This quota system is further detailed in the data analysis

\footnotetext{
${ }^{179}$ The system of endowed school land (学田) emerged very early during the Northern Song period (960-1127), and matured in the Qing dynasty. In general, endowed school land was land bestowed by the Court or donated by local elites, and used exclusively to support traditional academies, including county academies and prefecture academies.

${ }^{180}$ As noted in Chapter 2, the academies under the traditional education system were by modern standards equivalent to public higher education institutions. They enrolled students, only if they had already passed the first level of the Imperial Examination, the prefecture-level examination (乡试), to further their studies for the next level. They existed mainly in three forms: the Imperial Academy (国子 监), prefecture school (府学) and county school (县学). Therefore, the higher the quota granted to one county for successful candidates at the first level, the larger its academies might be.
} 
section. ${ }^{181}$ Localities which provided outstanding candidates in the Civil Service Examination were equipped with larger and more traditional academies, resulting in certain advantages in their modern replacements, in that they inherited better revenuegenerating channels.

In summary, a successful diffusion of primary education took place during the first half of the $20^{\text {th }}$ century, in which the role played by the central government and provincial powers was limited. While curriculum design was centralized, the authority and responsibility for other important elements of primary education, including finance and daily operation, were left entirely to county governments and even subcounty governing entities. Such success in increasing the number of local primary schools was largely sought through two financial channels: local levies and rents earned from land endowment, a legacy from the traditional education system.

\section{Was the prosperity the main determinant of the rising mass schooling in China?}

Despite political fragmentation and economic backwardness, modern primary education expanded remarkably in China throughout the first half of the $20^{\text {th }}$ century. How was public primary education so successfully diffused?

In theory, regions with more prosperous economies enjoy a larger tax base, and as a result can mobilise higher public funding and household income to support the expansion of education. At the same time, higher demand for skilled workers in economically advanced regions can result in a greater interest in education among the population. It is therefore natural to speculate that modern primary schools tend to be more prevalent in economically prosperous regions.

Unfortunately, the limitations in our data prevent us from testing this argument properly. As discussed in Chapter One, except for the benchmark year 1933, there are no concrete measures for GDP per capita, income level, the return to education and

\footnotetext{
${ }^{181}$ As an institutional means of controlling and regulating the power of local elites, a set number of candidates were assigned to each county and prefectural academy; the actual quota depended on the importance of each administrative unit.
} 
the share of agriculture in the economy at national level, let alone at the county unit level, for the period under discussion.

Even though we are constrained by a lack of the usual proxies for economic development across counties, there are some plausible indications to show where these wealthy regions were located. The existing literature has established that Chinese modern economic development was a regional phenomenon (Jia, 2014; Ma, 2008; T. Rawski, 1989). The main driver of economic growth was China's enforced 'opening-up' to the world economy after 1840. Most of the modern economic activity was concentrated in treaty ports, coastal areas and the Lower Yangtze Delta, which were believed to have better market access and institutional systems. Accordingly, we presume that these counties enjoyed better economic performance than the rest, and in the following section we classify them as 'rich \& open' counties.

As displayed in Table 4.5, the 'rich \& open' group shows a higher population density, ${ }^{182}$ and much more modern industry, confirming our assumption that these counties outperformed other regions in terms of economic development. However, in 1907these places appear to have had few educational advantages compared to other regions. For later periods, it is striking that, instead of delivering superior performance, the 'rich and open' regions showed poorer outcomes in primary education development, in terms of both school accessibility and enrolment rates. In 1916, only one primary school was available for 2,631 people in the 'rich \& open' regions, while enrolment ratios stood at $9 \%$. In contrast, the rest of China enjoyed much higher school density rates; one school per 1,886 people, leading to a higher enrolment $(10 \%)$. The same pattern holds true for 1932, with no sign of the gap having closed. The very short time slot during when 'rich \& open' counties outperformed in primary schooling development was at the very start of the new system. This may reflect fact that greater exposure to Western ideas facilitated the acceptance of this new educational model. However, this 'first mover advantage' was not maintained in the following decades.

\footnotetext{
182 The only sensible proxy for economic conditions at county level for the period under discussion is population density. In a pre-modern economy, such as China, the more densely populated regions are highly likely to have a more advanced agriculture sector and to be more commercialised, and so have a more advanced economy.
} 
Map 4.1: The 'open and rich' regions vs. the rest of China

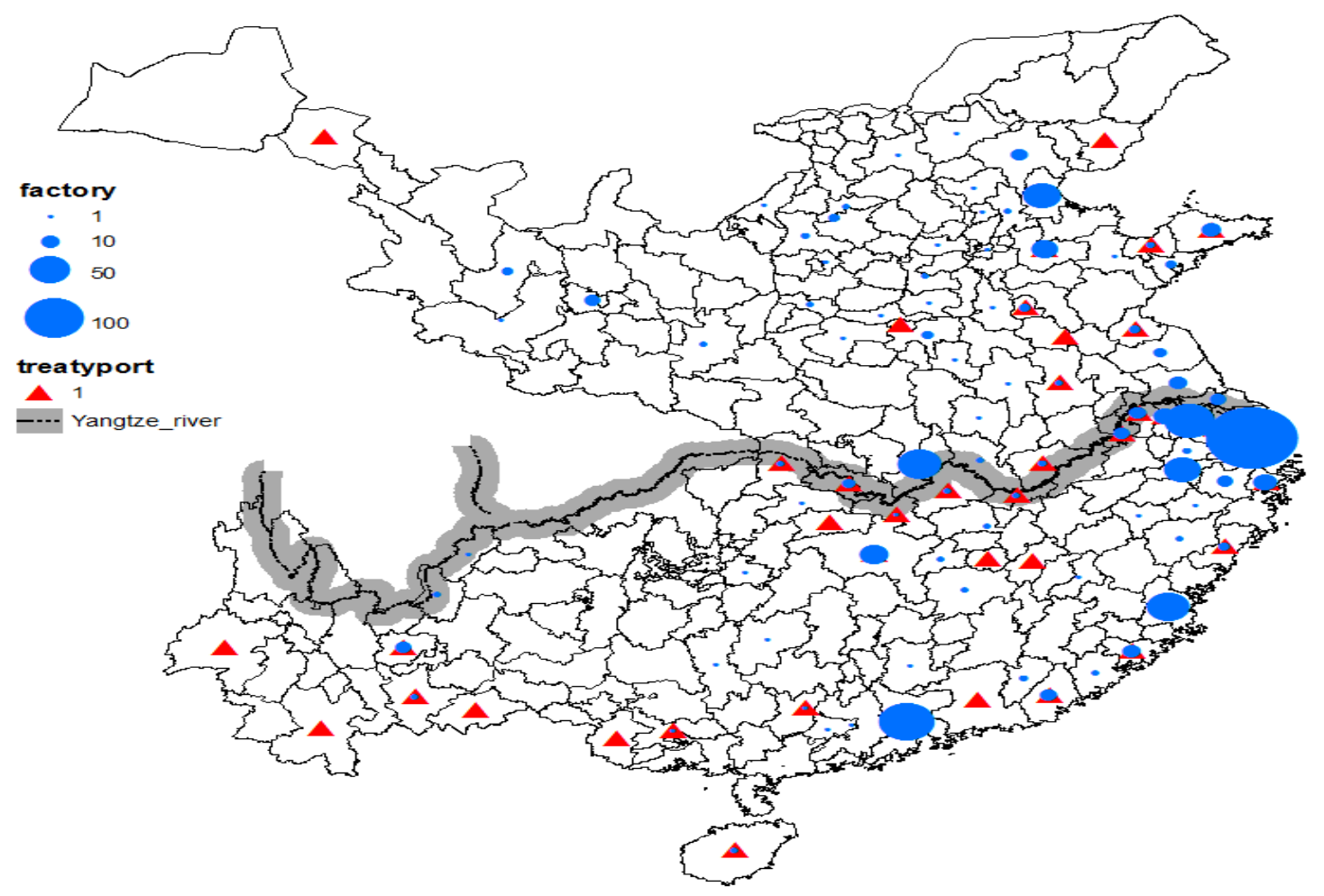

*This map covers only China proper, without the province of Sichuan. Blue dots indicate regions with domestic modern factories. Red triangles refer to treaty port. The grey line illustrates the Yangtze River.

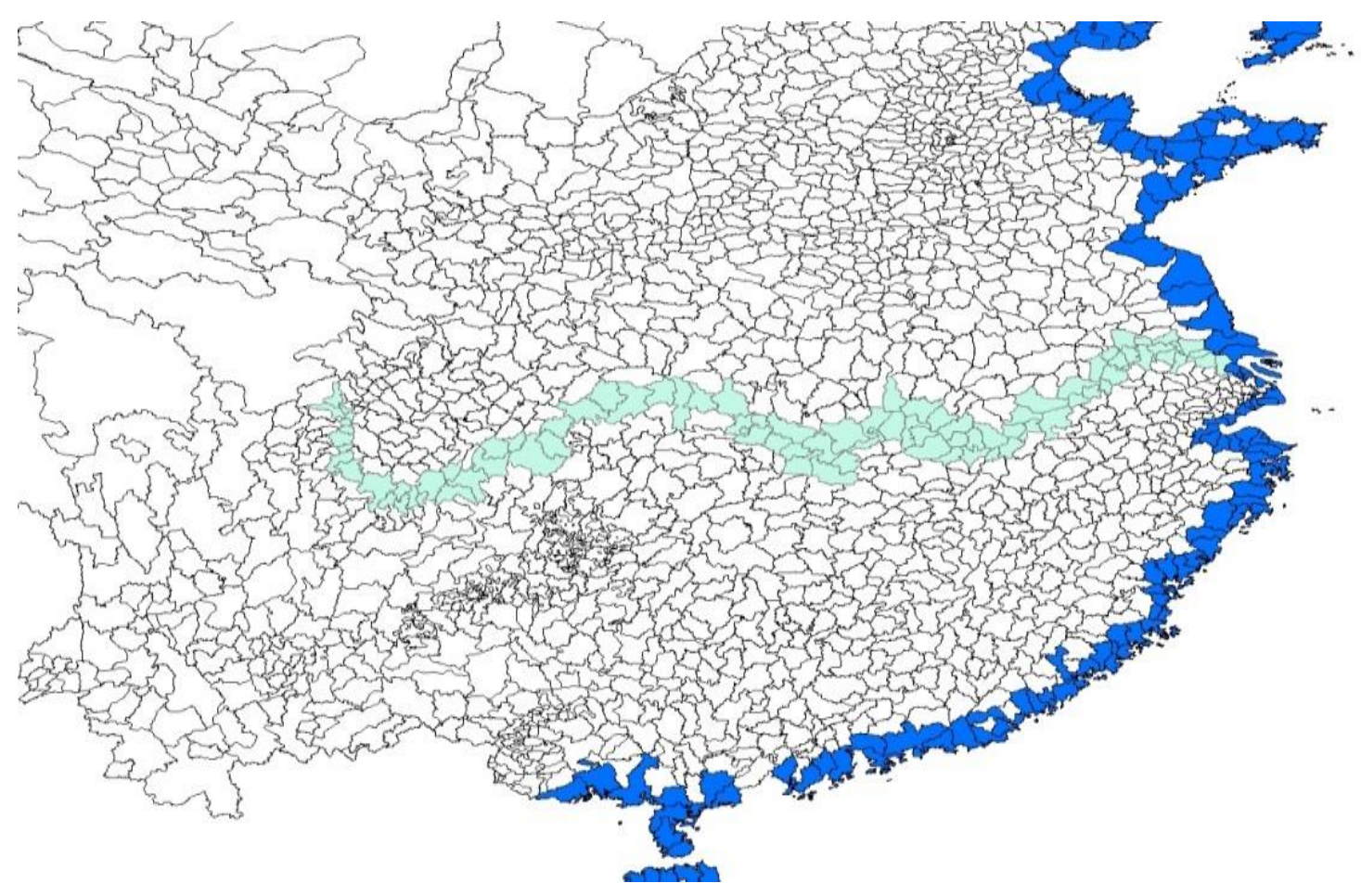


Table 4.5: Statistical summary for primary schooling level by group

\begin{tabular}{lccc|ccc}
\hline & \multicolumn{3}{c|}{ Rich \& Open } & \multicolumn{3}{c}{ The Rest } \\
\cline { 5 - 7 } & obs & mean & std.Dev & obs & mean & std.Dev \\
\hline $\mathbf{1 9 0 7}$ & & & & & & \\
Population density & 223 & 268.35 & 320.7 & 804 & 157.12 & 174.09 \\
Modern industry & 223 & 0.41 & 0.39 & 804 & 0 & 0 \\
Enrolment ratios & 223 & 2.32 & 5.31 & 804 & 1.79 & 2.6 \\
Schools per 1000 people & 223 & 0.13 & 0.21 & 804 & 0.14 & 0.42 \\
\hline \multicolumn{1}{c}{$\mathbf{1 9 1 6}$} & & & & & & \\
Population density & 309 & 267.19 & 264.83 & 871 & 148.51 & 141.1 \\
Modern industry & 309 & 0.26 & 0.43 & 871 & 0.056 & 0.23 \\
Enrolment ratios & 309 & 8.94 & 6.21 & 871 & 9.52 & 8.99 \\
Schools per 1000 people & 309 & 0.38 & 0.31 & 871 & 0.53 & 0.48 \\
\hline \multicolumn{1}{c}{$\mathbf{1 9 3 2}$} & & & & & & \\
Population density & 151 & 263 & 308.11 & 435 & 202.9 & 314.46 \\
Modern industry & 151 & 0.28 & 0.45 & 435 & 0.071 & 0.25 \\
Enrolment ratios & 151 & 21.28 & 13.64 & 435 & 22.78 & 44.98 \\
Schools per 1000 people & 151 & 0.65 & 0.39 & 435 & 0.95 & 1.53 \\
\hline
\end{tabular}

*Source:

(i). 1907:

Ministry of Education(1907), Guangxu Diyici Jiaoyu Tongji Tubiao (The first statistic report on Education)

Population: To construct 1910 county level population, we apply the county level variations within a given prefecture based on 1920 data(Stauffer, 1922) to the 1910 prefectural population data (Cao, 2000; Z. Yan, 1955).

(ii).1916:

National Board of Education(1916), Zhonghua Minguo Jiaoyu Tongji Tubiao (The education statistic report for Republica of China, fifth)

Population: (Stauffer, 1922)

(iii).1933:

Unlike 1907 and 1916, there is no national yearbook on county-level schooling information nor population in 1930s; instead, a number of provinces published government reports on education enclosing detailed statistics respectively. We gather 10 provinces that published similar education reports in 1930s, including Fujian, Guangdong, Guangxi, Guizhou, Henan, Hubei, Hunan, Jiangsu, Shanxi, and Zhili, covering 787 counties.

Education Bureau of Fujian Province(1930), Fujiansheng Jiaoyu Tongji (Education reports of Fujian province)

Education Bureau of Guangdong Province(1935), Guangdongsheng ershisan niandu Jiaoyu Gaikuang (The education reports of Guangdong Province in 1933)

Education Bureau of Guangxi Province(1932), Guangxisheng Jiaoyu Tongji (The education reports for Guangxi Province)

Education Bureau of Guizhou Province(1932), Guizhousheng Jiaoyu Tongji (The education reports on Guizhou province)

Education Bureau of Hebei Province, Hebeisheng Gexian Putong Jiaoyu Gailan (The county-level reports for general edcuation in Hebei province), 1928

Education Bureau of Henan Province(1930), Henan jiaoyu yianjian (The education yearbook of Henan province)

Education Bureau of Hunan Province(1931), Hunan quansheng Jiaoyu Tongji (The education reports for Hunan province), 
Education Bureau of Jiangsu Province (1933), Jiangsu Jiaoyu Gailan (The education reports for Jiangsu province)

Statistic Department of Shanxi Province(1930), Shanxisheng Dishici Jiaoyu Tongji (The tenth education report on education in Shanxi province)

Education Bureau of Hubei Province(1932), Zuijin Hubei Jiaoyu Yilan (The education reports on Hubei province)

More rigorous empirical tests are applied and presented later in this thesis. However, this simple statistical result already provides us with one interesting finding: that the " rich \& open' places, which are believed to enjoy better geographic location, institutional set-up, and economic performance, enjoyed only their early adopter advantages for a very short time, and then fell behind in the task of spreading primary education to the people. In other words, the rise of primary schooling cannot be fully explained by the level of economic development.

\section{Interest groups on education provision}

As discussed in previous section, all the educational decision were made at local level, how did local interest groups' preferences play out and drive the public primary education diffusion successfully in China through this period?

\subsection{Was the commitment from govern the driving force?}

In theory, mass schooling system is largely an outcome of government, given that public efforts, including financial source and government administration, constitute the main contributor. In this section, the preferences, intentions and capacities of each level of government regarding the primary education agenda are explored.

\subsubsection{The limited role of central, provincial powers and populace}

\section{1). The central state}

As discussed earlier, the Qing and later Republican governments played little part in the course of China's primary schooling expansion. The primary education system had originally been designed to be delegated to county governments, while at the same time, central government's loosening grip on local administration further reduced its ability to supervise and control primary education. Even when it came to curriculum design, the highest priority of central government in this area, very little 
actual implementation was achieved by the central state apart from issuing edicts on paper concerning models for primary school curricula.,

\section{2). Provincial powers}

Provincial powers responded differently to the agenda of 'promoting mass schooling'. Given the regional political fragmentation and weakening central control, not all the provincial leaders were prepared to bend over backwards to achieve the top-down targets set by the central government. To generalise, people who aligned themselves closely with the central state would have much more incentive to carry out this education reform, as a sign of political conformity. But those who counted themselves as opposing powers, or those who engaged in political and military struggles might have had little interest in implementing 'expensive' ventures in national education.

Apart from regional politics, provincial leaders' personal preferences may also have mattered. A few cases emerged where provincial leaders zealously promoted modern public schooling within their territories as a sign of their passionate personal commitment to education, rather than of their sense of political responsibility for attaining the central government's target. A famous example is Xishan Yan, who ruled Shanxi province for four decades. ${ }^{183} \mathrm{He}$ published a small booklet and newspapers within Shanxi, which enthusiastically promoted mass schooling. ${ }^{184}$ In 1918, Yan insisted that all school age children in his domain had to attend primary school for at least 4 years, and spoke frequently of the importance of mass schooling: 'Mass education consists of instilling within the mass of the people the proper attitudes and virtues' - Xishan Yan (Gillin, 1960, p. 70) Apart from Yan, there were a few other regional leaders, who also emphasised educational development; most of them had themselves previously obtained a good education. ${ }^{185}$ However, others

\footnotetext{
${ }^{183}$ For instance, Xishan Yan, the son of a merchant, ruled Shanxi province for almost the whole Republican era. He was famous for his zealous commitment to mass education. Yan believed that the problems confronting China could be solved only through the moral rehabilitation of the people, which can be achieved only by mass schooling. He therefore keenly promoted primary education by making four years of schooling compulsory for all children, and compelling the rich to subsidise public education through taxes (Gillin, 1960). At the end of the Republican period, Shanxi, as the obvious front runner in terms of modern schooling promotion, had a primary enrolment ratio that already reached a similar level to Japan's, leaving other provinces in China far behind.

${ }^{184}$ For instance, Yan published a village daily, entitled Village Talk (Cun Hua); at the same time, he tended to use posters, plays and slogans to spread his political and ideological propaganda.

${ }^{185}$ For instance, Peifu Wu, who ruled Zhili province, was often referred to as a 'scholar warlord', because he gained the title of Jinshi (the highest degree level under the traditional education system). Another warlord, Jiongming Chen, obtained Shengyuan status, and furthered his Western education by study in Guangdong School of Politics and Law. Both of them actively encouraged education in their
} 
responded to this education policy with much less support, and hardly any intention of making mass primary education their spending priority.

\section{3). People's resistance}

The new education system was not solely the product of government. Acceptance on the part of the people who would actually send their children to school played a distinctive role. Despite the seeming virtues of the modern education system, to a great extent the masses in fact resisted it.

The reason for such resistance was largely a fiscal matter. The increasing tax burden fell on all local residents; however, the benefits of the modern schooling system were not evenly spread. ${ }^{186}$ For an average Chinese resident, the whole purpose of an education was to learn how to read and perform basic calculations. Therefore, the much more expensive modern school system, proudly providing Western subjects as an 'optional' mode of education, failed to appeal to ordinary peasants who, like everyone else had to pay for it. ${ }^{187}$

Moreover, stronger resistance came from the cultural perspective. The new type of schooling was a severe threat to the enduring social norms and conventions of local residents. Both the traditional schools that provided Confucian classical education and the religious Tang at which local residents worshipped their ancestors were regarded as the most important symbols of the legitimacy of traditional culture. As noted above, many modern schools confiscated the buildings and materials of the traditional academies and Tangs. This resulted in much social protest, even massacres, as documented in gazetteers and newspapers. Zhang and Ding recorded a full list of protests and riots between 1901 and 1911. Among these, it is clear that anger at the new levies were the foremost and most common trigger. Of the 450 protests recorded, 17 were attributed to the levying of a new tax to support modern education (Z. Zhang

own provinces, and also contributed significantly to promoting gender equality in education. Unfortunately, many other provincial leaders were in contrast completely indifferent to the education agenda, and devoted little effort to its progress.

${ }^{186}$ According to the calculations in Chapter Three, the average period of schooling in the early $20^{\text {th }}$ century lasted only about two years; thus modern schooling had little relevance to most rural Chinese.

${ }^{187}$ A large proportion of rural children still enrolled in local sishu, because of the relatively low tuition fees and easy access. Their parents did not want to pay tax to fund modern primary schools for them. 
\& Ding, 1982), suggesting that resistance to any new tax was strong, to education levies above all.

\subsubsection{County governments: local implementation}

As emphasised, nearly all educational decisions on primary schooling were delegated to local level, and according section 2.2 , it is clear that most of primary schooling were financed by tax revenue collected by government. Were county officials the ones who carried out the execution regarding promoting primary schooling such policy? What kind of incentive did they bear?

Local politics in early $20^{\text {th }}$ century China failed to meet one necessary condition for delivering functioning governance - political stability. Olson (1993) sketches a pattern under which greater government accountability emerges in places with higher political stability (Olson, 1993). Accordingly, it is only in politically stable conditions that a government can have an effective long-term horizon in which to function. If the political future is unpredictable, a government has very little incentive to provide public goods, such as education, which generate no short-term benefits. Many historical narratives portray China from the late $19^{\text {th }}$ century as undergoing political turmoil at national level; however, ascertaining the extent of political instability at the county unit is a much more challenging task. Here, we exploit the frequency in the turnover of county magistrates to reveal a general picture of the political stability of different localities. We collected more than 500 county gazetteers containing relevant information on magistrates. ${ }^{188}$ As Table 4.6 shows, throughout the Republican era the average time that a county magistrate was in office was notably short. The data suggest an exceptionally high frequency of reshuffles of local officials, with more than half the counties' magistrates serving only from six to twelve months. ${ }^{189}$ To provide a comparable reference to the figure, under Qing rule the term of a magistrate in office was at least 3 years, bearing in mind that the personal evaluation of each

\footnotetext{
${ }^{188}$ County gazetteers(县志), sometimes translated as chorography. In Chinese history, every county compiled gazetteers to record the geographic, political, social and economic contents of the locality. Under a new regime, new content would be added, but the old records were not replaced. For this study we collected more than 500 county gazetteers published in the 1990s, which contained information on magistrates in its locality for the whole Republican period.

${ }^{189}$ Instability and confusion was similarly server at upper level of government. There were 24 cabinet reshuffles, and for the post of prime minister alone, there were people held the office between 1916 and 1928(H. Chi, 1976, p. 2).
} 
magistrate took place once every 3 years $\left(\mathrm{Qu}, 2003\right.$, p. 60). ${ }^{190}$ In short, the frequent reshuffles in office created a remarkably unstable local political and administrative climate.

Table 4.6: Turnover of county magistrates

\begin{tabular}{|c|c|c|c|c|c|c|}
\hline \multirow{2}{*}{$\begin{array}{l}\text { Local } \\
\text { magistrates }\end{array}$} & \multicolumn{6}{|c|}{ Average length in office (years) } \\
\hline & $<0.3$ & $0.3-0.5$ & $0.5-1$ & $1-1.5$ & $1.5-2$ & $>2$ \\
\hline 1911-1917 & 0.59 & 9.7 & 64.71 & 12.94 & 7.06 & 4.9 \\
\hline 1917-1932 & 0 & 3.07 & 55.36 & 26.3 & 3.97 & 7.33 \\
\hline
\end{tabular}

Note: This table relies on information from a large collection of Chinese gazetteers. I collected information on 592 counties, the gazetteers of which recorded the names and tenure of its magistrates through this period. The list of county gazetteers is too long to present here, and can be found in the Appendix B.

Even if there were sufficient time for county magistrates to put their policies into practice, they had no clear political incentive to provide public goods. Without the granting of a political voice to the masses, local authorities were not accountable to the people. In theory, one way to enhance the effectiveness of local governments and local officials were accountable through the tight control of their career prospects via the personnel appointment system. Under such institutions, even without local elections, local officials were strongly incentivised to attain the goals set by their superiors in order to advance their political career. ${ }^{191}$ However, the reward mechanisms through this trying period had very vague targets on specific responsibilities of county magistrates should achieve, ${ }^{192}$ and placed far more emphasis on political conformity than on governing performance. ${ }^{193}$ In other words, displaying

\footnotetext{
${ }^{190}$ Under Qing rule, after each three-year evaluation, the magistrate would be allowed to stay, relocated, or advanced in office (Qu, 2003, p. 60). Compared with the norms in the Qing dynasty, the tenure time for magistrates throughout the Republican era seem considerably reduced.

${ }^{191}$ A target-setting framework contributed substantially to China's economic development after 1978. Even though officials faced no pressure from local elections, the Communist Party tightly controlled the appointment system of local officials over a wide range of targets. The targets are usually easily measurable ones, for instance GDP growth.

${ }^{192}$ As discussed in section 2.2 of Chapter One, what specific activities a county magistrate should undertake had never been made explicit in Chinese history (Chien, 1950, pp. 43-45; Qu, 2003, pp. 2934). The relevant regulations stayed similarly vague in the Republican period.

${ }^{193}$ With the abolition of the civil service examination, a new recruitment process was set up, which combined recommendation by high officials, a review by the Ministry of the Interior, and a newly designed magistrates' examination (Wou, 1974). In practice, the actual appointment was often handled
} 
political loyalty to a provincial leader or a certain faction played a dominant role in local officials' careers and their advancement (Chauncey, 1992; McDonald, 1978). ${ }^{194}$

Furthermore, supervision from the provincial and central governments was so weak that even if governing performance were considered an important criterion for a local official's future prospects, it would be highly unlikely for upper level government to receive an accurate and timely account of performance. Taking education as an example, throughout the Republican era, very few local educational inspections were held, and detailed education records were available for very few years; thus evaluating one magistrate's governing performance on the basis of educational development was ruled out.

With such minimum incentives, why did local officials take huge political risks by levying non-statutory surcharges against central government's regulation to build up primary schools? Did they do it for the purpose of corruption? The eroded state capacity did in fact enable local governments to increase their fiscal capacity, if not autonomy, and such liberty paved the way for local exploitation. There is no denying that some exploitative and extractive governance was observed in some regions. ${ }^{195}$ Starting from the late 19th century, the great increase in the number of new local levies caused an outbreak of anti-tax riots, some of which even developed into significant rebellions against the government (Z. Zhang \& Ding, 1982). However, no large-scale predatory behaviour towards local residents was recorded, and the extent of the disruption to local governments' day-to-day operations was less than expected (Mccord, 1993, pp. 81-118; Q. Wang, 2000). Moreover, for schooling in particular, the tax revenue collected was indeed directed to the increasing number of modern primary schools.

In conclusion, an examination of the incentive structure and fiscal capacity of local government raises a puzzle. Facing no institutional checks, clear political incentives or even legitimate fiscal tools, we see local governments making non-obligatory

on an informal basis, and, because of the lucrativeness of those posts, they were usually assigned by the regional leaders as an important forms of leverage for establishing their own local patronage networks. ${ }^{194}$ For instance, all counties experienced a very fast turnover of magistrates around 1927, because after the success of the northern expedition, the Nanjing government attempted to integrate various regional powers under its control. 
efforts to collect non-statutory surtax, not for purposes of corruption and predation, but for increasing the provision of local public goods. Why?

\subsection{The real decision maker: local gentry}

As discussed in section 2.2 of Chapter One, there had been a power sharing between officials and other elite groups at local level through Chinese history(C. Chang, 1955, pp. 51-70; K. G. Deng, 2011, p. 26; Qu, 2003, p. 31; Remick, 2004), and the seizing of local power by elite groups was enhanced through the late $19^{\text {th }}$ century and early $20^{\text {th }}$ century to fill local administrative vacuums(Keenan, 1994; Lary, 2007, pp. 50-51; Mccord, 1993, pp. 81-118; Sheridan, 1977). Therefore, the development of mass education was not determined solely by local officials' incentive. Instead, it was an outcome affected by the dynamics of vested interest groups within local politics.

The more critical interest group in local politics was a specific social elite group - the gentry. As discussed in Chapter One, throughout the crisis-ridden final ages of Qing, and the chaotic first few decades of the $20^{\text {th }}$ century, there was an expansion of gentry management in local communities. It has been widely observed that local elites stepped in to ensure the continuation of order in local civil administration. Drawing evidence from historical narratives, the gradual assumption of authority over taxation and appropriation of public facilitates after the late Qing period became common (Chauncey, 1992; Dennerline, 1975; Keenan, 1994, pp. 125-141; Mccord, 1993, pp. 81-118; McDonald, 1978; Remick, 2004; Sheridan, 1977; Wakeman \& Grant, 1975, pp. 1-25). Therefore, it is not an overstatement that when it came to decisions about local public school the real decision makers were not local officials, but the local gentry.

To begin with, defining the so-called gentry in China is worth careful explanation. ${ }^{196}$ The term 'gentry' in China refers to people who had obtained their prestigious status from success in the civil service examination and who as a result could hold office. Their rank could not be inherited. The gentry members, who can be equated to degree

\footnotetext{
196 The term 'gentry' (士绅 or 缙绅) has no full equivalent in English. Sometimes people translate 士 绅 into 'elites', but in most cases, the term 'gentry' is used as a widely acceptable translation. Gentry in Europe are usually associated with large land-holdings and aristocracy, both of which are inheritable. Therefore, the term has a distinctively different meaning in the Chinese context.
} 
holders, constitute the most important social elite group in Chinese history, and only comprise the top 0.5 per cent of the whole Chinese population (C. Chang, 1955, p. 102; Ni \& Van, 2006).

Surprisingly, few researchers have thought to connect local gentry to modern schooling. The few studies that are based on micro-historical evidence vividly illustrate how closely members of the local gentry were involved in urging the development of modern schooling throughout this period (Chauncey, 1992; Keenan, 1994; Liao, 1936; McDonald, 1978; Wen, 2002; B. Zhang \& Qin, 2001). Owing to the inseparable link between the gentry and education, it is difficult to neglect their intentions and interests in furthering the agenda of modern education. This section surveys the political and economic relevance of the local gentry to gauge their power and predict their preferences in the rise of modern education.I

\subsubsection{The structure of local gentry}

In order to understand the interests and preferences of the gentry, we begin by noting that the gentry were a far from homogenous group of people, who enjoyed similar social prestige and sources of income; on the contrary, its membership can be divided into two opposing tiers, with different career paths, economic bases and social status (C. Chang, 1955, pp. 6-8; Ho, 1962, pp. 17-41).

The top tier of the gentry included bureaucrats already in office and high (middle) degree holders who were qualified for official appointments. To be eligible as an official, holders of at least the degree of Jinshi, Juren and Gongsheng could be selected for the Imperial Academy as students. According to Graph 3, all the top three types of degree holder were higher tier gentry, who were eligible to hold a government post.

The lowest tier of gentry consisted of the lowest degree holders called Shengyuan or Xiucai who had passed the licensing examination (院考) in a prefectural capital or had purchased an equivalent degree. In most cases, success in this level of the Civil Service Examination brought only the title of gentleman, exemption from corporal punishment and corvée (labour service), special arrangement regarding tax payments 
Figure 4.2: The structure of gentry \& levels of the Civil Service Exam

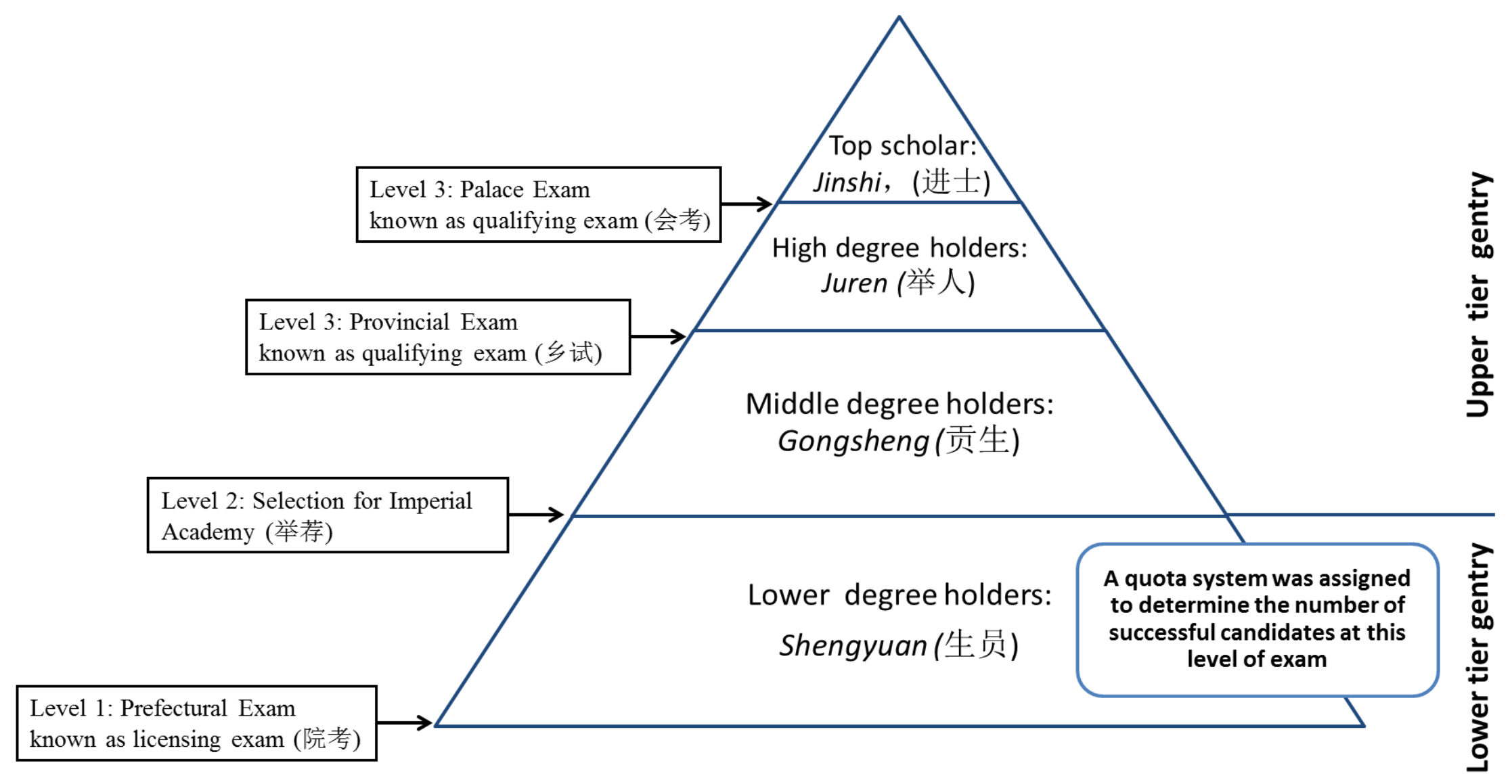

*Source: (C. Chang, 1955, p. 9) 
and entitlement to wear a scholar's robes, but not a guarantee of entering the civil service and becoming a bureaucrat (C. Chang, 1955, pp. 32-43; Ho, 1962). In fact, only less than 3 percent of Shengyuan had the chance of attaining office, leaving most holders of their rank gentry ignored by officialdom (C. Chang, 1955, p. 118).

\subsubsection{The long-standing functions of the gentry in local communities}

Members of the top tier gentry were only allowed to take official posts outside their own home province. ${ }^{197}$ Lower degree holders (Shengyuan) who were ineligible to hold office, usually remained in their home localities, and constituted a large proportion of the educated elite class outside the bureaucratic system in rural China.

The importance of the gentry, mainly the lower ranks, in governing local affairs was not novel in Chinese history. It is understood to have shaped the political fabric and social structure of local society in various forms. On the one hand, regulations forbade county-level officials to have come from the locality where they served; therefore, they possessed very limited knowledge and information about local conditions. To cope with their uphill task, they relied heavily on cooperation and assistance from the local elites, including members of the gentry (Qu, 2003, p. 31; Remick, 2004). On the other hand, given that direct state control never penetrated beyond county level (K. G. Deng, 2011, p. 26; Qu, 2003, p. 5), the daily life of rural people was organised in the village as a unit, which was based entirely on a foundation of local gentry. ${ }^{198}$ As a literate body and social elite, the gentry filled most of the influential and lucrative posts, including village heads, ${ }^{199}$ relief managers, tax agents for the local tax bureau, clerks for magistrates and, of course, school managers and teachers (C. Chang, 1962; Duara, 1988, p. 159; Wakeman \& Grant, 1975, p. 4). Through such activities, they provided local communities with their personal leadership, and inspiration, as well as their knowledge.

\footnotetext{
${ }^{197}$ This is an edict used by the Qing Court to prevent regional patronage. Usually, the top tier gentry would play an influential role in their own hometown only after retiring from their official posts.

${ }^{198}$ As discussed in section 2.2 of Chapter One, a village was not state administrative unit; therefore the head of a village was not a state official either. When a village attempted to elect its own head, the village council, which normally consisted of the local elites, usually chose a candidate from its own circle. Thus, the local administration was largely in the hands of local elites.

${ }^{199}$ Village heads possessed extensive authority ranging from village finance and crop watching to village defence.
} 
One noteworthy feature is that owing to the influential function of the gentry in local management, the state made clear its intention to restrain the power of this elite group and to balance the number of bureaucrats from different regions. To this end, a quota system was designed and imposed at the first level of the civil service exam for each county. ${ }^{200}$ Under this system, each county received a quota figure regulating the number of candidates who would be allowed to pass the first level of the exam (licensing exam), and consequently, the number of lower gentry (lowest degree holders) in each county were directly under the control of the Qing Court. ${ }^{201}$ This quota will be further explored in the empirical strategy of the research below in this chapter.

In summary, the vital function served by the gentry in local management has a long history, and was further enhanced during the early $20^{\text {th }}$ century due to the political confusion and new demands for public services ${ }^{202}$ created by a wave of urbanisation and modernisation. ${ }^{203}$

\subsubsection{Motivation of local gentry in modern education}

Given that they served an irreplaceable function in local affairs, what were the specific interests of the traditional gentry in the sector of modern primary education?

\footnotetext{
200 There were two kinds of quota. Besides the quota assigned directly to each county, there was another, prefectural, quota. The figure was allocated to each prefecture as a whole and could be shared between counties, but the prefectural quota was comparatively small.

${ }^{201}$ The quota system for the entry level of exam was assigned to the county as a unit, while the quota for the higher level of exam was imposed on the province as a unit.

${ }^{202}$ For instance, the birth of the first municipal government in Shanghai demonstrated clearly that the local elites' seized power to ensure the increasing public demand for facilities due to urbanization. After the first Sino-Japanese war, Shanghai's local figures started to run the new city council to carry out long-standing projects required by this speedily expanding metropolis, such as widening streets and building bridges(Ma, 2008).

${ }^{203}$ The increasing activities of local gentry in the public domain were various; here, we mainly emphasise their determination and efforts to expand education. Another crucial example of local elites' increasingly important role lay in the lijin tax collection. The collection of this main source of tax revenue was quasi-official in practice, and even further empowered the local elite's legitimacy in local public affairs (Yi Xu, 2009). Since the gentry took extensive responsibility for local management, there were even some attempts to institutionalise the role of the gentry into formal politics by absorbing gentry members into the local assemblies or establishing an elective Council, which would existed for 2 years only before being abolished (S. Cheng, 1919, p. 138). For instance, the founding of the county assembly, composed of local elites, was originally part of the Qing Court's preparation for the constitution in rural areas. Interrupted by the 1911 Revolution, county assemblies still became the principal voice on community matters ranging from annual tax rates to the provision of public goods (X. Zhang, 2000, p. 49).
} 


\section{1). Social obligation and official-endorsed management}

One obvious incentive for the gentry's being active in promoting education was a sense of obligation befitting their social rank. The gentry, with their prestigious status from the state-sanctioned examination, had a long history of showing moral responsibility in local management. Numerous records document local gentry's superintending public works to maintain bridges, ferries, walls and temples, sponsoring and printing local gazetteers, participating in local sacrifices and Confucian rituals, and organising relief for refugees (C. Chang, 1955, pp. 51-70; Qu, 2003, pp. 282-330). In the same vein, the gentry's active engagement in local schooling had long existed, and they provided financial means, personal leadership or simply knowledge in the sector of education. ${ }^{204}$

Moreover, apart from their sense of public obligation as social elites, the gentry's role in the administration of local education was organized as a government-delegated authority, which was endorsed, if not encouraged, by the state during the first half of the $20^{\text {th }}$ century. Looking at the task of primary education in particular, the Education Act 1904 specifically notes that "Local officials may select gentry members ... and charge them with responsibility for the management of modern educational affairs" (F. Wang, 1994). Accordingly, the chief officers and staff of county education bureaus were all appointed from the local gentry, and not from state officials (Chauncey, 1992; Keenan, 1994, p. 111). ${ }^{205}$ On the same lines, the gentry's predominant responsibility in the education sector held good down to the grass-roots level (villages and districts). The state specifically outlined three criteria for a director of a school district, one being the need to have obtained at least Shengyuan status

\footnotetext{
204 The most wealthy and powerful gentry families often initiated, managed, and more importantly, funded some social organisations to help local young people obtain a better education. For instance, Juying hui (聚英会) and Zhuying hui (助英会), as Chinese names, literally indicate that they had the function of specifically 'helping young talent'. Later, in the Republican era, they transformed themselves into Education Associations, the most influential local civic organisations, but their essential structure and purpose remained.

205 The chief officers and volunteer officials of the education exhortation bureaus (renamed to county educational bureau later) were filled by highly respected local people, gentry members in most cases. After 1922, when the Education Bureau replaced the exhortation bureaus, its function in practice did not change. The director of the Educational Bureau and four educational committee members were all leading gentry as well. Another purely civil organisation emerged, the Educational Administrative Committee, comprising nine members; all of whom supposedly served without payment. They consulted with the head of the education bureau (Gamble, 1954, p. 189).
} 
(Keenan, 1994, p. 126). ${ }^{206}$ At village level, all schools had a board which was responsible for the primary school's operations, the members of which, as well as other village leaders, also had to be local gentry.

\section{2). Private interests: job markets}

Their private economic interests also shaped the traditional gentry's motivations for engaging in public education and other public projects(Wakeman \& Grant, 1975, p. 4). As mentioned, gentry members had very diverse income sources and career paths. For the lower tier, whose title led primarily to social status with no assurance of an official post, education had long served as one possible job market. Examples of this multiplied after the education expansion following the late Qing period, in particular. Many gentry members took jobs in supervising the construction of schools, managing school operations and teaching (Keenan, 1994, pp. 1-5). Indeed, the local education sector constituted a desirable job market and potential source of income for local gentry.

The importance of the local education sector as a job market for these traditional degree holders was substantially enhanced throughout the early $20^{\text {th }}$ century. Given the close link between gentry status and the Civil Service Examination, the discontinuation of the exam in 1905 had a devastating effect on their legitimacy as social elites (B. Elman, 2000; Esherick, 1990, pp. 294-296). With this system gone, the old patronage networks were torn down and replaced by other things (Keenan, 1994, pp. 131-132). Eventually, the traditional gentry lost their legitimacy as the elites in society, and held no more advantage in many job markets than did the newly emerging elites, including new scholars, national capitalists and state technocrats, most of whom were equipped with a modern education and were concentrated in the big metropolitan centres or treaty ports (Y. Li, 2005, pp. 33-41). More and more posts in the public sphere cease to prefer traditional degree holders; on the contrary, a modern education background became an advantage. ${ }^{207}$ For instance, more than half

\footnotetext{
${ }^{206}$ The other two criteria were first, that the director should be from the locality; and second, that he should have some experience of background working in education.

${ }^{207}$ Modern education became an advantage in the job market during the early $20^{\text {th }}$ century, in particular for the public sector. This implies that modern education had become a very important selection criterion for the new bureaucrats after the civil service was dismantled.
} 
of the cabinet ministers from 1920 to 1928 had received a modern education or had even been educated abroad. The impetus to earn a living became increasingly important, not to say urgent, for gentry members in a period when their potential job market was shrinking. People who had studied abroad dominated the tertiary education sector, and secondary schools were full of people who had received at least some modern education. ${ }^{208}$ For traditional gentry members, a job in primary education stood as one of the few available routes to career advancement and a secure financial future.

In conclusion, by exploring the preferences and intentions of each interest group in the local educational circle, we find a paradox: weak local government officials seek to collaborate with traditional gentry (lower degree holders) who themselves have been rejected by Chinese Imperial officialdom. A further decline in status and earning with the abolition of the civil service exam made local gentry particularly proactive in the sector of primary education, thanks both to their long-standing public moral obligation and the private economic interests associated with the spread of schooling.

Table: Education and background of Cabinet Ministers, 1920-28

\begin{tabular}{|l|l|l|}
\hline Education background & number & per cent \\
\hline Classic Education & 52 & $55.32 \%$ \\
\hline Modern Education & 9 & $9.57 \%$ \\
\hline Military Academy Education & 14 & $14.89 \%$ \\
\hline Educated Abroad & 51 & $54.26 \%$ \\
\hline
\end{tabular}

${ }^{208}$ Universities and secondary schools were extraordinarily concentrated in very limited regions, therefore controlled by newly emerging elites based in urban centres. For instance, in 1907, among 1410 counties for 16 provinces, only 231 counties had secondary schools established, and $71.2 \%$ of which were prefecture seats, implying tremendously high level of urban bias. Similarly, among 1501 counties, only 242 counties obtained secondary schools in 1916, and the ratio remained as $32.9 \%$. Such concentration of higher education institutes in prefecture seats and provincial capitals implies that traditional gentry in rural localities had little chance to be included into this new educated elite circle. 


\section{Data}

To empirically test the hypothesis outlined above, I assembled a new county-level dataset for most of the provinces in China Proper ${ }^{209}$ so as to explore the spatial variations in the diffusion of primary education in China for the period 1907-1933, and further pin down what factors accounted for its regional dispersion. Most of the dataset relies primarily on digitising contemporary sources, covering about 1,000 counties, occupying $20 \%$ of the whole territory but $80 \%$ of the population in the Qing period (Cao, 2000).

In order to identify the driving forces of China's development of schooling in the the period of interest, two key variables are examined. One focus of this chapter is to test whether the strength of the local social institution, the gentry class, was important in deciding modern education. The other is to measure the political stability across counties in China. Apart from these two key variables, we also collect rich information for measuring primary schooling expansion, together with a great many potential indicators of economic development at the county unit level. In the following sections, we define the variables and provide a basic summary of the statistics for the empirical analysis.

\footnotetext{
${ }^{209}$ We exclude Manchuria and Tibet, Xinjiang and Qinghai, other peripheral provinces, both due to the inaccessibility OF data and the different schooling systems operating in these regions. Inside China Proper, moreover, we have no data for Sichuan province.
} 
Map 4.2: The Geographical Data Covered

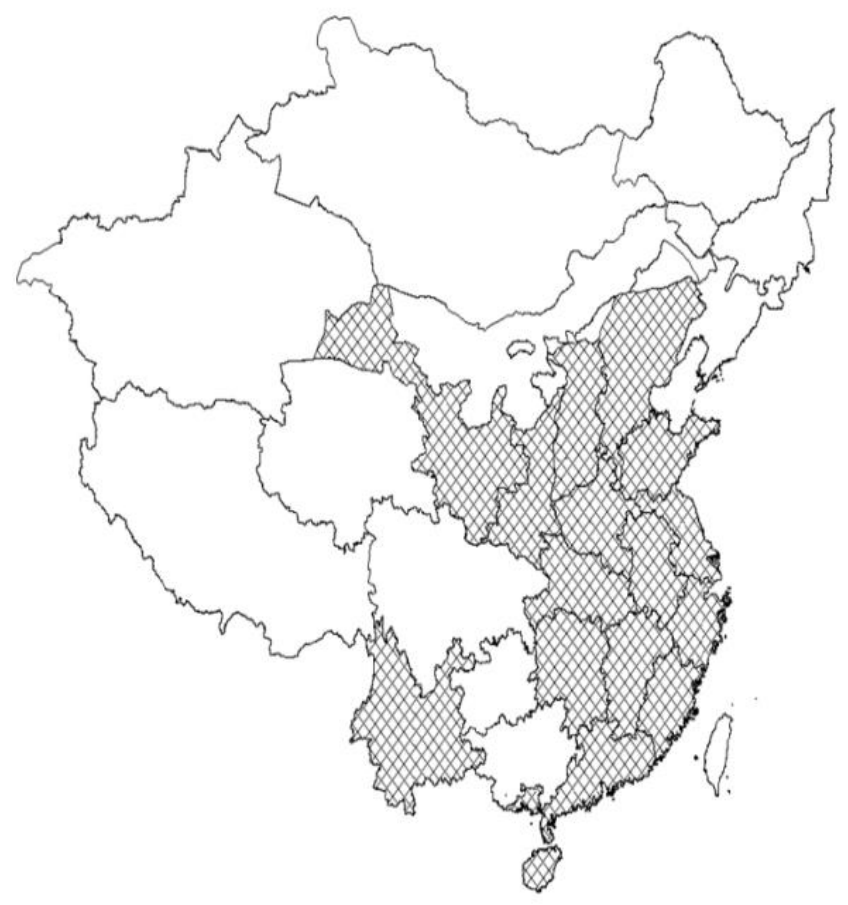

Panel A: Data coverage in 1907

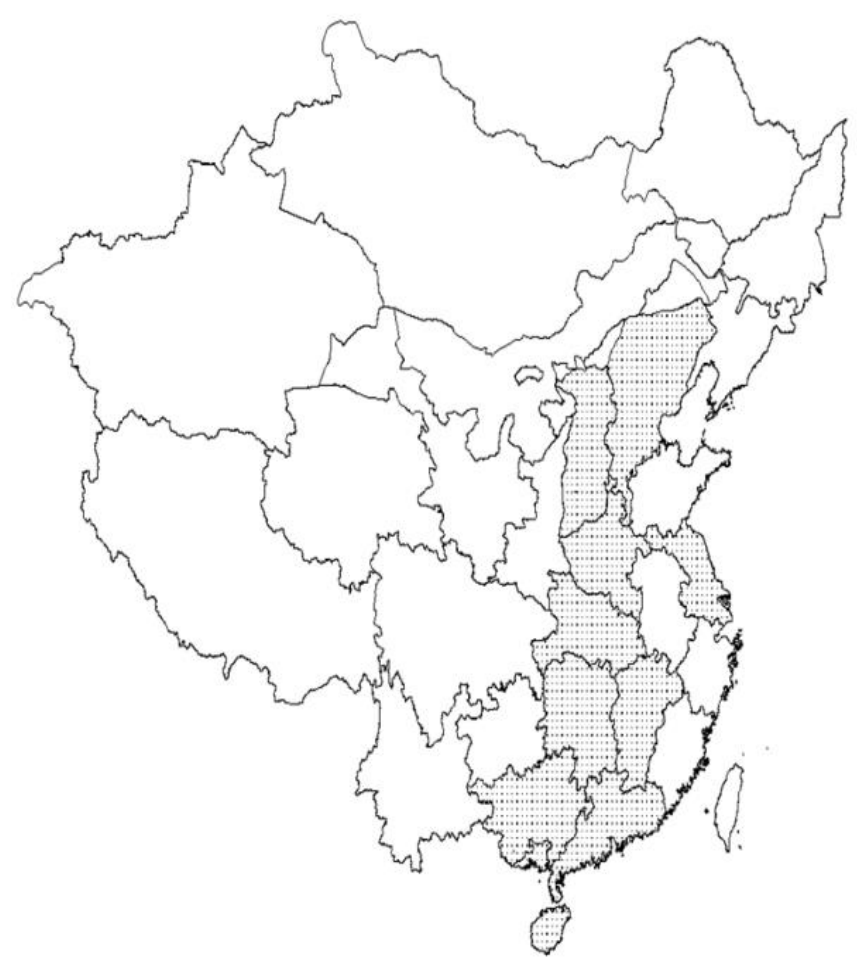

Panel C: Data coverage in 1930

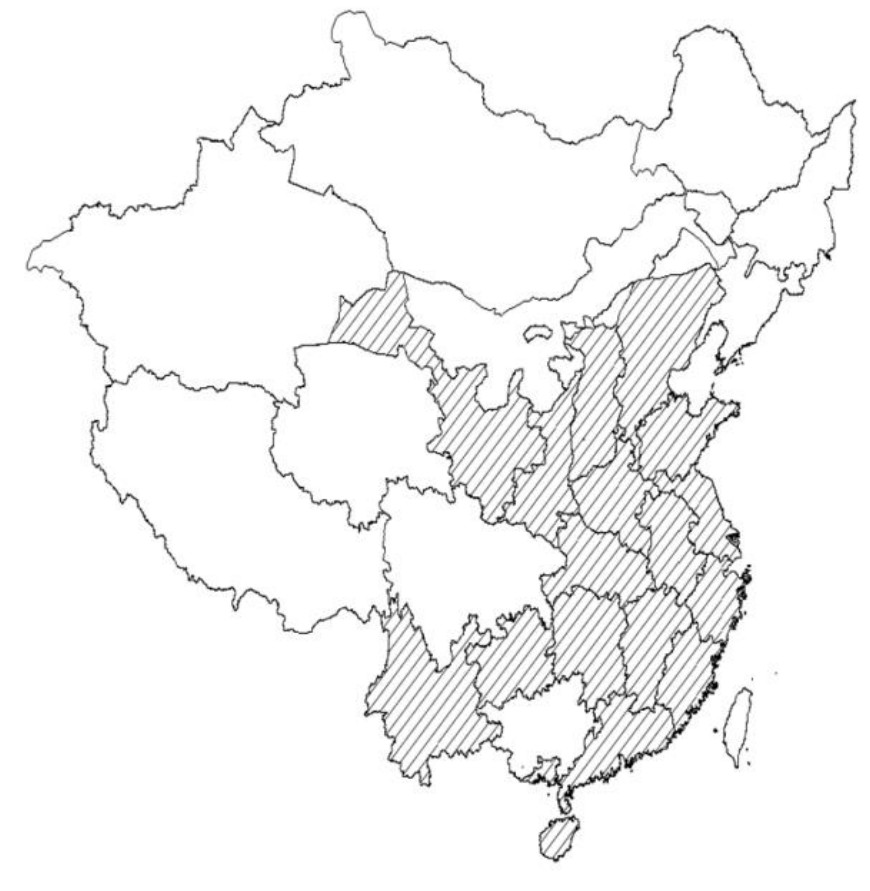

Panel B: Data coverage in 1916

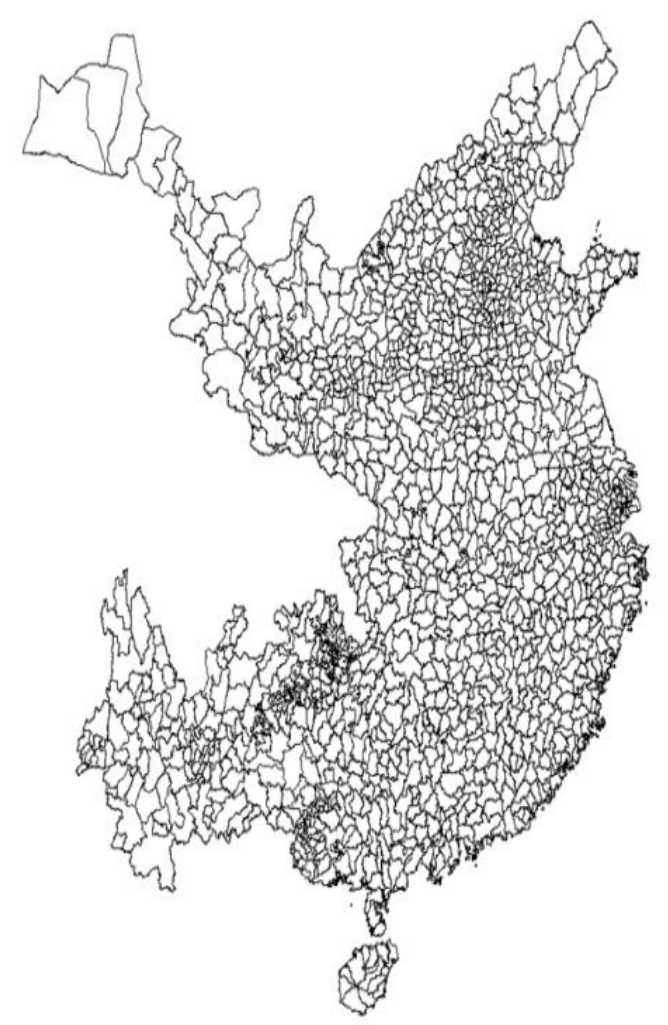

Panel D: Sample counties 


\subsection{Measuring the rise of primary schooling}

The dependent variables are educational indicators in three benchmark years: 1907, 1916 and 1932. The educational provision is measured as school density over 10,000 people and primary education expenditure per capita. The schooling outcome is measured as the primary enrolment ratio. For some regions and years, we also construct a teacher-student ratio as a proxy for education quality.

1). Primary school density: the number of primary schools normalised by both population (per 1,000 people) and land area (per $1,000 \mathrm{~km}^{2}$ ) to reflect the supply of primary schooling. School density is an indicator of schooling accessibility, which is an essential predictor of schooling outcomes. It may be particularly important when society face sharp contrasts in terms of transportation.

2). Primary enrolment ratio: this is one of the most standardised measurements of schooling outcome.

3). Primary schooling expenditure per capita: this is a widely used indicator of schooling provision, which directly measures the level of investment in maintaining and expanding schooling.

4). Student-teacher ratio: this is a commonly used proxy for education quality, where the higher the student-teacher ratio, the lower the quality of schooling.

Our data show that in 1907 there were on average only 1.34 primary schools for every 10,000 people, resulted in primary enrolment ratios barely standing at $1.9 \%$. Primary schooling experienced such extensive expansion that by 1916 primary school density had risen by more than 3 times, reaching a figure of 4.9 primary schools for every 10000 people; similarly, primary enrolment ratio soared to $9.4 \%$. In 1933 , with a slightly smaller sample, the primary school density had almost doubled, reaching 8.9, while the primary enrolment ratio had risen to $22.7 \%$. 
Table 4.7: Summary statistics for dependent variables: schooling variables ${ }^{210}$

\begin{tabular}{llllll}
\hline Schooling Variables & Obs & Means & S.D & Min & Max \\
\hline 1907 & & & & & \\
Primary enrolment ratio & 1027 & $1.90 \%$ & 0.034 & $0.01 \%$ & $45.18 \%$ \\
Primary school density by population & 1027 & 1.34 & 2.7 & 0.0003 & 3.41 \\
& 1027 & 0.198 & 0.446 & 0.0005 & 9.17 \\
Primary school density by area $\left(1000 \mathrm{~km}^{2}\right)$ & & & & & \\
\hline 1916 & 1066 & $9.42 \%$ & 0.0881 & $0.22 \%$ & $84.24 \%$ \\
Primary enrolment ratio & 1066 & 4.9 & 4.7 & 0.0074 & 4.875 \\
Primary school density by population $(1000$ people) & 1066 & 0.807 & 1.159 & 0.0012 & 23.99 \\
Primary school density by area $\left(1000 \mathrm{~km}^{2}\right)$ & 1066 & 0.086 & 0.24 & 0.0012 & 4.62 \\
Primary expenditure per capita & 1066 & 31.58 & 102.58 & 1.18 & 2541 \\
Student-teacher ratio & & & & & \\
\hline 1933 & 787 & $22.65 \%$ & 0.177 & $0.29 \%$ & $84.24 \%$ \\
Primary enrolment ratio & 787 & 8.9 & 8.1 & 0.01 & 5.29 \\
Primary school density by population $(1000$ people) & 787 & 1.32 & 1.18 & 0.0001 & 9.95 \\
Primary school density by area $\left(1000 \mathrm{~km}^{2}\right)$ & 787 & 0.38 & 0.69 & 0.004 & 7.6 \\
\hline Primary expenditure per capita & & & &
\end{tabular}

\footnotetext{
*Sources:

i.1907:

Ministry of Education(1907), Guangxu Diyici Jiaoyu Tongji Tubiao (The first statistical report on Education)

Population: To construct 1910 county level population, we apply the county-level variation within one prefecture based on 1920 data(Stauffer, 1922) to the 1910 prefectural population data (Cao, 2000; Z. Yan, 1955)

ii.1916:
}

National Board of Education (1916), Zhonghua Minguo Jiaoyu Tongji Tubiao (The education statistical report for the Republic of China, no. 5); Population: (Stauffer, 1922)

iii.1933:

Unlike 1907 and 1916, there is no national yearbook on county-level schooling information nor population in 1930s; instead, a number of provinces published government reports on education enclosing detailed statistics respectively. We gather 10 provinces that published similar education reports in 1930s, covering 787 counties.

Education Bureau of Fujian Province(1930), Fujiansheng Jiaoyu Tongji (Education reports of Fujian province)

Education Bureau of Guangdong Province(1935), Guangdongsheng ershisan niandu Jiaoyu Gaikuang (The education reports of Guangdong Province in 1933)

Education Bureau of Guangxi Province(1932), Guangxisheng Jiaoyu Tongji (The education reports for Guangxi Province)

Education Bureau of Guizhou Province(1932), Guizhousheng Jiaoyu Tongji (The education reports on Guizhou province)

Education Bureau of Hebei Province, Hebeisheng Gexian Putong Jiaoyu Gailan (The county-level reports for general edcuation in Hebei province), 1928

Education Bureau of Henan Province(1930), Henan jiaoyu yianjian (The education yearbook of Henan province)

Education Bureau of Hunan Province(1931), Hunan quansheng Jiaoyu Tongji (The education reports for Hunan province),

${ }^{210}$ To avoid the significant influence of major urban centres, we exclude large counties such as Shanghai and Canton. 
Education Bureau of Jiangsu Province (1933), Jiangsu Jiaoyu Gailan (The education reports for Jiangsu province)

Statistic Department of Shanxi Province(1930), Shanxisheng Dishici Jiaoyu Tongji (The tenth education report on education in Shanxi province)

Education Bureau of Hubei Province(1932), Zuijin Hubei Jiaoyu Yilan (The education reports on

Hubei province)

\subsection{Measuring the strength of local gentry}

As discussed earlier, in certain political conditions, the local gentry had an incentive to step in and contribute formally or informally to the rise of primary education in their own communities. Therefore, one focus of this chapter is to test the role of the gentry in explaining the successful spread of primary education.

The great challenge facing this study is how to quantify the power of the gentry. Given the difficulty of measuring the strength across counties of the local elites in the early $20^{\text {th }}$ century, this research exploits the size of the gentry population to measure their power in different places. As pointed out in section 3.2.2, the degree holders constitute the local gentry. Data on the number of different levels of degree holders in Qing dynasty is used as a proxy for the strength of the local gentry during the period under review.

\section{1). The number of lower tier gentry:}

As noted earlier that the number of Shengyuan, who were the scholars passed the first-level exam (licensing exam), was under control by a quota system. ${ }^{211}$ The quotas on shengyuan are illustrated in Figure 4.3, which shows that the quotas varied widely across counties. The different quotas for Shengyuan each time the exam was held accumulated throughout the Qing dynasty, leading us to assume that places with higher quotas would generate more lower degree holders (Shengyuan).

\footnotetext{
${ }^{211}$ The Qing state followed the regulations through from the Ming dynasty to impose a strict quota system on the number of candidates who could succeed at every administrative level of the Civil Service Examination. The system controlled the distribution across regions of the opportunity to join the gentry. It was used as an institutional means to confine and regulate the size of the population of gentry (Bai, 2014; B. Elman, 2000, p. 140). For higher degree candidates, such as Jinshi and Juren, who were required to pass the provincial-level exam, the quota was allocated at the provincial level. For lower degree holders, the quota system was assigned to prefectural and county levels. One feature of the quota system was that regional quotas remained stable through the Qing dynasty; only after the Taiping Rebellion, in order to encourage and reward the local contribution to the quelling of the rebellion, did a substantial increase occur for many places, notably the Lower Yangzi delta.
} 
The Imperially Established Institutes and Laws of the Great Qing Dynasty（大清会 典) carefully documented the quota system across counties through the Qing period (Kun, 1899). Although the quota system remained stable between 1644 and 1851, because of the outbreak of the Taiping Rebellion (1850-1864), the Qing government increased the quotas for many regions in order to strengthen its alliances among the local gentry against rebel forces(C. Chang, 1955, pp. 83-92; Ho, 1962, pp. 181-183; Kun, 1899).. After the war, the revised quota assigned in 1873 persisted until the abolition of the exam. Figure 4.4 shows that originally the most commonly assigned numbers were at first $8,12,14$ and 20 , but that the expansion of quotas after the Taiping Rebellion increased the variation between quotas significantly. In this chapter, data from both periods are analysed. Our main analysis uses quota figures from the latter period, but the results are robust if quotas in the early period are used.

\section{Figure 4.3: Distribution of Shengyuan quota, for both early and late Qing}
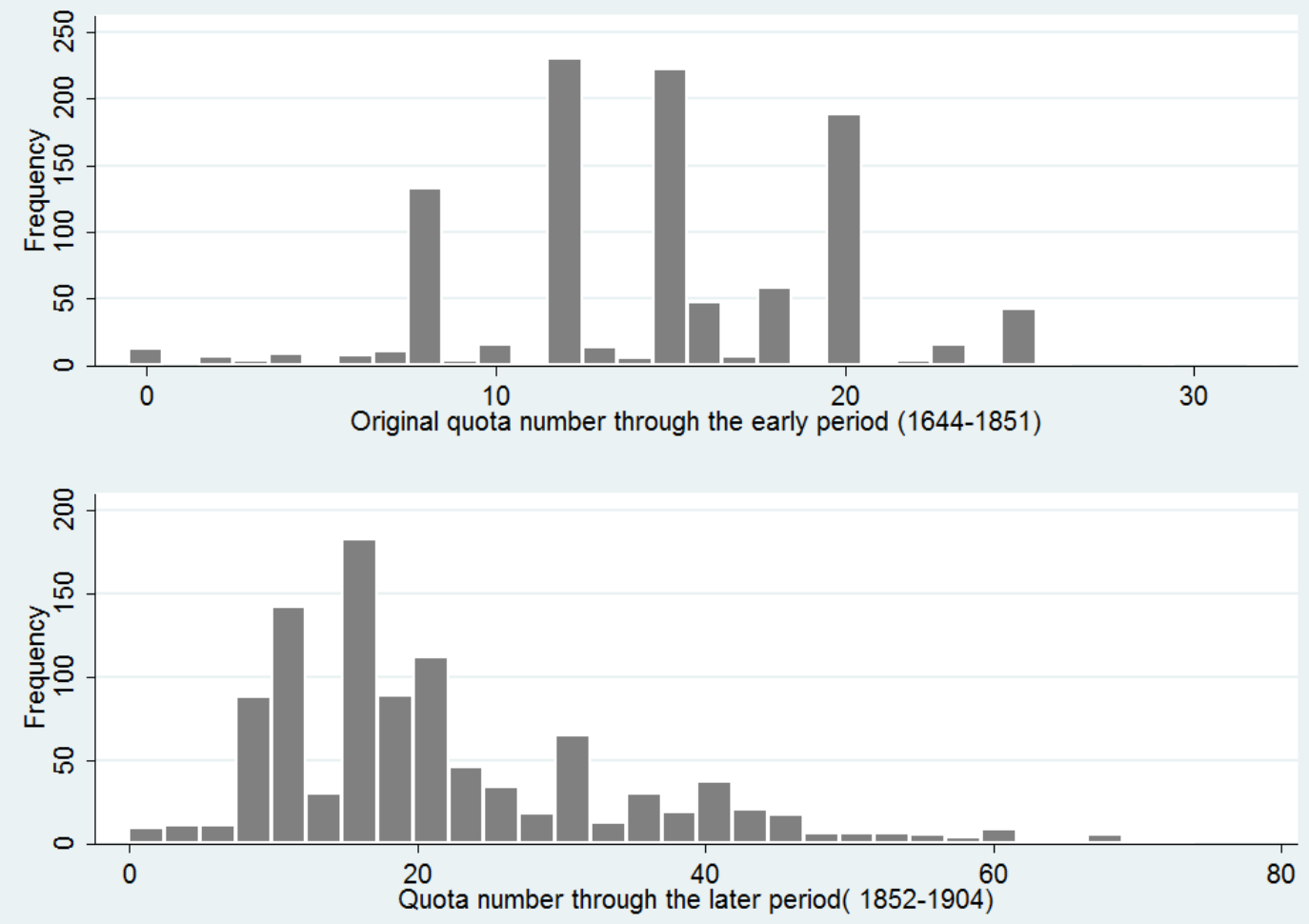

Sources: (i). Shengyuan Quota:(Kun, 1899) (ii). Jinshi: (Jiang, 2007)

According to Table 4.8, the number of gentry occupied only a small proportion of the population. The average quota was only 13 per county through the most of the Qing period, but, after the quota expansion during the Taiping Rebellion, the average quota 
increased to 19 per county. Normalized by the 1910 population, on average there were only 1.58 Shengyuan over every 10,000 people.

Table 4.8: Summary statistics for the numbers of the gentry

\begin{tabular}{lccccc}
\hline Gentry Variables: & Obs & Means & S.D & Min & Max \\
\hline $\begin{array}{l}\text { Quota for Shengyuan_(lower degree holders) } \\
\quad \text { Original Shengyuan quota }\end{array}$ & 1499 & 13.24 & 6.14 & 0 & 32 \\
$\quad$ Shengyuan quota in the later period & 1499 & 19.43 & 13.2 & 0 & 74 \\
Shengyuan quota density in late Qing (per 10000 peope) & 1499 & 1.58 & 1.66 & 0 & 20 \\
Accumulated number for Jinshi (higher degree holders) & 1499 & 14.22 & 27.4 & 0 & 306 \\
Jinshi density in late Qing & 1499 & 0.86 & 1.3 & 0 & 13 \\
\hline \hline
\end{tabular}

*Source: Shengyuan: (Kun, 1899); Jinshi:_(Jiang, 2007)

\section{2). The number of top tier gentry}

Jinshi: As displayed in Figure 4.2, Jinshi was highest scholarly rank under the traditional education system. Jinshi did not count as local gentry in most cases, but we can use the number of higher degree holders as a robustness check. There was no quota system imposed on Jinshi numbers at county level; therefore the regional variation in numbers is more likely to be a merit-based result. For the top scholars under the traditional education system who obtained the title of Jinshi, both the Ming and Qing dynasties kept detailed personal records (Jiang, 2007). We collect the accumulated numbers at the county unit level of people who attained this rank as a measurement of the size of the foremost gentry.

\subsection{Measuring political stability}

In order to measure the political stability at the county level, which is the main administrative unit that accounted for spread of education across China, we use the frequency of turnover of county magistrates. There are many studies on the effect of the term limits. Length of term may influence incumbents' accountability, including the tendency to provide public goods in democratic societies(Besley \& Case, 1995).

\footnotetext{
${ }^{212}$ The Jinshi density in late Qing is calculated by the accumulated Jinshi numbers through the Qing era and then normalised by the population in 1910 .
} 
Does a leader's length of stay in societies such as China, without the pressure of local elections, impact on his commitment to providing public goods? Even without direct evidence for the period under discussion, the literature on communist China after 1978, when a decentralised and authoritarian political system prevailed, confirms that county heads' tenure has an inverse U-shaped relationship with school infrastructure spending, reaching its peak in their third or fourth year in office ( $\mathrm{Lv} \& \mathrm{Liu}, 2013)$.

More than 500 surviving county gazetteers were gathered to gain relevant information on county magistrates. In order to match the two benchmark years for schooling, we used the average length of time that each county magistrate served in office ${ }^{213}$ for two time windows: 1911-1917 and 1917-1933. The average length of time that a magistrate remained in office was about 1.22 years for the first period, and 1.13 for the second period, suggesting that, if we draw references from contemporary China, the average number is far from reaching a tipping point whereby an inverse- $U$ starts to fall (Lv \& Liu, 2013).

Table 4.9: Summary statistics for the turnover of county magistrates

\begin{tabular}{lccccc}
\hline County Magistrate Turnover & Obs & Means & S.D & Min & Max \\
\hline 1911-1916:average tenure in office & 592 & 1.22 & 0.701 & 0.29 & 5 \\
1917-1933:average tenure in office & 592 & 1.13 & 0.806 & 0.32 & 8 \\
\hline \hline
\end{tabular}

*Note: This table relies on information derived from a large collection of Chinese gazetteers.

I collected information on 592 counties, the gazetteers of which recorded the names and reshuffle times of its magistrates through this period. The list of county gazetteers it can be found in a table in the Appendix B.

In theory, one potential weakness in employing figures of magistrate turnover to measure political stability is the problem of endogeneity. Is it possible that a magistrate who provided better education would stay in office longer because of his better performance? This concern is valid in most cases, but cannot be applied in China in the historical period under study. The appointment and replacement of county magistrates was closely associated with the dynamics of local politics or the struggles in the upper levels, but not with individual achievement (Q. Wang, 2000; Y.

\footnotetext{
${ }^{213}$ In order to avoid the problem of counting data in further regression studies, the turnover times of county magistrates are converted to figures for average tenure in office.
} 
Zhang, 1999). ${ }^{214}$ In short, given the particular context of the period under discussion, it is reasonable to assume that the length of one magistrate in office was not endogenously decided by his performance in providing public goods.

\subsection{County characteristics}

In order to measure the effect of factors associated with economic development on schooling provision and primary enrolment ratios, we need information on the regional distribution of economic prosperity across China between the late Qing period and the Republican era. Unfortunately, data such as household income, industry structure and GDP per capita are not available. As a substitute, a long list of alternative proxies for economic development is adopted in this study.

\section{Agricultural production capacity:}

Given that China was an agrarian economy through the first half of the $20^{\text {th }}$ century, the strength of the agricultural sector reflected overall economic prosperity. The importance of agriculture is enhanced by the fact that land tax was for a very long time the main source of tax revenues for the Chinese state. This would suggest that the state's capacity should have been higher in regions with better agricultural production.

1). Soil quality and agriculture production:

Soil quality has long been considered as one partial determinant of a locality's agriculture production. Given the lack of historical data on agricultural production, we construct a cross-sectional variation in the suitability of the soil for growing rice and wheat in $1960 .{ }^{215}$ If we assume that the distribution of soil quality did not change systematically over time, it could be a proxy for potential agricultural production capacity across counties in the early 20th century. This information comes from the Global Agro-Ecological Zones (GAEZ) database compiled by the Food and Agriculture Organisation (FAO). The database divides the entire globe into 2.2 million grid cells, with each cell covering around 50 square kilometres. Most Chinese

\footnotetext{
${ }^{214}$ For instance, all the counties experienced very frequent turnovers in magistrates around 1927 , because the Nanjing government, after the success of the northern expedition, tried to integrate the various regional powers under its control.

215 The database provides information on the potential yields of 154 crops in each zone, and I have chosen wetland rice and wheat, which have low input levels.
} 
counties cover 6 to 98 cells. Map 4.3 illustrates the distribution of suitability for rice and wheat, with darker areas more suitable for agricultural production.

\section{2).Fiscal capacity: Land tax quotas in the late Qing period}

To ensure that soil suitability is a sound proxy for historical agricultural development, we also, as an alternative measure, exploit land tax quotas, which are closely associated with agricultural yields,. The latest systematic surviving records on land tax per prefecture through the Qing dynasty were documented in 1820; therefore, this measurement loses variation across counties within the same prefecture. ${ }^{216}$ Additionally, this land tax quota remained unchanged for the previous almost 100 years, implying that it is not time-sensitive, either, to the changes in agricultural production.

\section{Modern industry:}

The effect of modern industry on schooling diffusion requires special attention. According to global evidence, manufacturing has created a demand for child labour, because the nature of the work does not require high physical capacity. ${ }^{217}$ For China during the period under discussion, the biggest sector in modern industry was manufacturing, and testing whether its presence tended to slow education progress is especially important. The ideal measurement of modern industry strength would be the exact composition figures of shares of employment in the manufacturing sector across counties; however, the relevant data is not available. As a substitute, the cumulative number of domestic modern firms between 1841 and 1915 is adopted as a proxy to reflect the strength of modern industry (Y. Chang, 1989). ${ }^{218}$ Second, aware that modern domestic industries were sparsely scattered across China, we construct a dummy variable for whether modern industry operated in a given county.

\footnotetext{
${ }^{216}$ Furthermore, this tax data does not directly provide actual agricultural productivity, but a quota set by the Qing court, which remained the same for almost 100 years.

${ }^{217}$ In early industrialised countries, such as the UK and US, poor children had worked for centuries before industrialization, but it profoundly changed the nature of child labour. Following the increasing number of modern mills and factories, an untold number of children were hired in factories to prepare and spin cotton, flax, wool and silk (Carolyn, 2001; Goldin \& Sokoloff, 1982).

218 There were some strict criteria for defining a modern industrial firm, the main one being that, instead of human power, the operations of a firm must be powered by a steam engine or electricity. Chang also uses other criteria in terms of size; ( (1) have registered capital of at least 10,000 silver yuan, 8 (2) employ at least 30 workers, (3) produce an annual output of at least 50,000 silver yuan in value, and (4) have adopted modern (hierarchical) management practices (Y. Chang, 1989).
} 
Map 4.3: Soil suitability for major crops

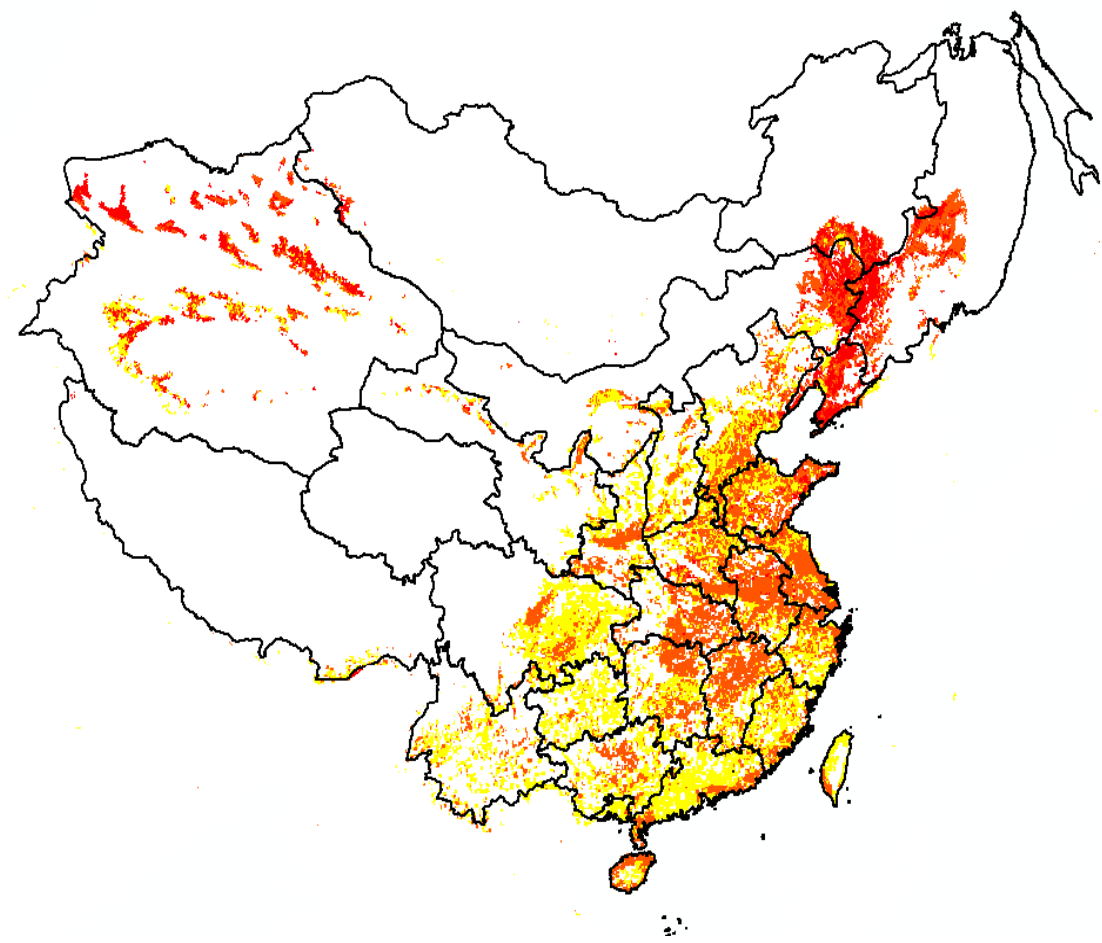

soil suitablity for wetland rice.t

Value
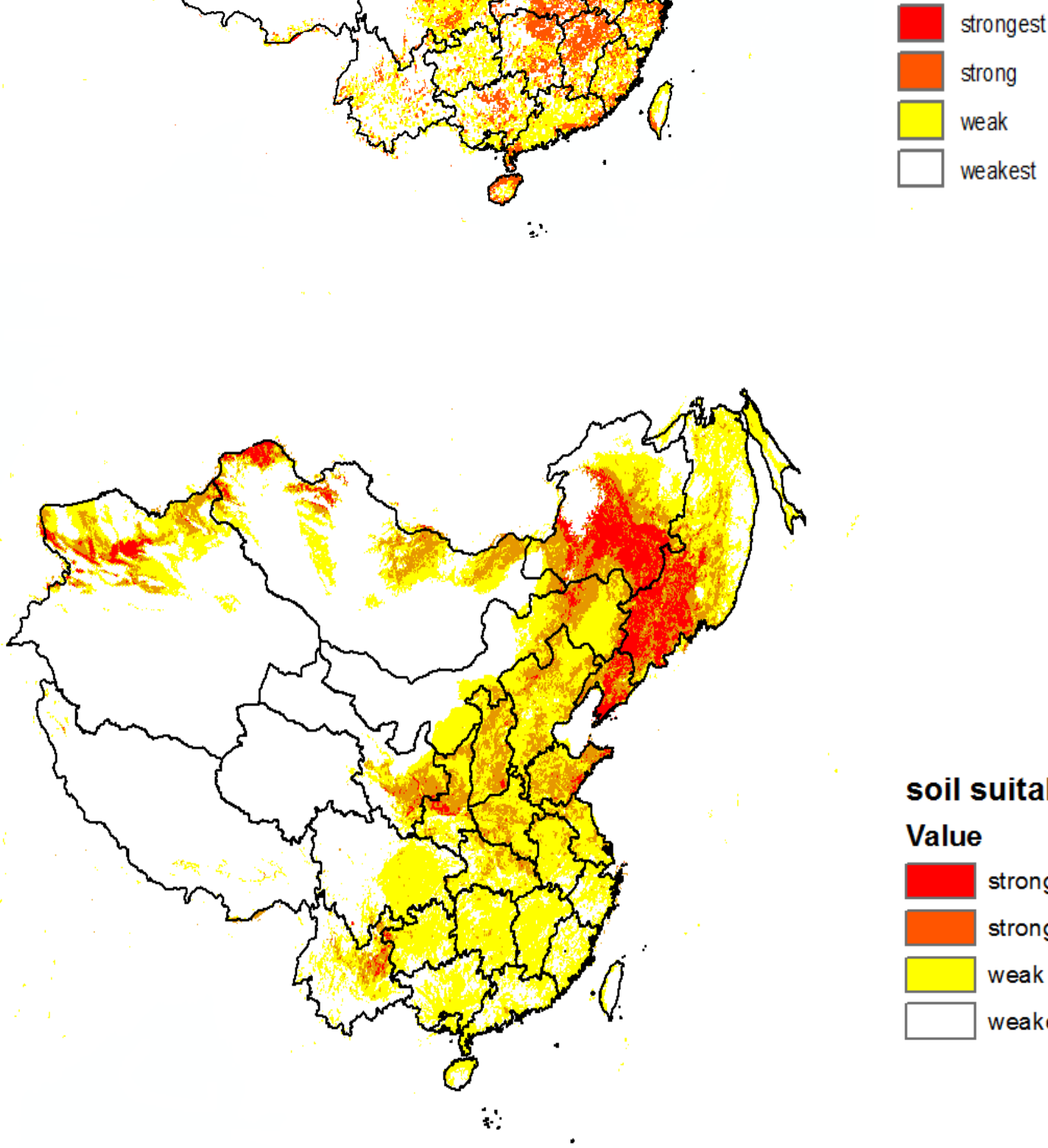

soil suitablity for wheat

Value

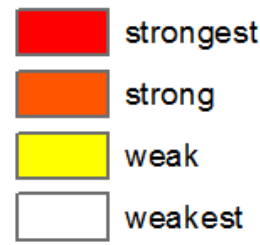

Source: FAO.(2012), Global Agro-ecological Zones (GAEZ v3.0) 


\section{Western penetration:}

Western influence penetrated many dimensions of Chinese life from the 1840s onwards, and foreign ideals deeply affected the expansion of modern schooling. The influence as a whole can be divided into two channels. First, from an ideological perspective, the new education system was modelled on the Western practice, which was completely different from the traditional Confucian teaching and delegitimised the long-standing literati-bureaucrat system in China. More exposure to Western ideas may have encouraged people to be more receptive to modern ideas, including a new education system. In addition, from a 'learning by doing' point of view, missionary schooling, as a pioneer in China, was the best model for local governments to follow; accordingly, places with more missionary schooling may be expected to provide better primary schooling performance.

To model Western penetration, we construct three variables. First, a treaty port dummy: port cities that were open to foreign trade under unequal treaties. These cities were often equipped with foreign legal institutions and enjoyed more access to foreign trade and investment. ${ }^{219}$ (treaty port $=1$, otherwise $=0$ ) (Z. Yan, 1955, pp. 42-56). Second, we use as indicators the number of communicants per 10,000 people and the enrolment ratios for missionary primary schools to capture the penetration of missionary work. The third proxy is the distance to its nearest telegraph station. The telegraph was first introduced in China in 1871 . Until 1911, only $18.76 \%$ of the counties had an established telegraph station (Bol \& Ge, 2007; Da Qing youzheng gongshu beiyong yutu (China postal working map) 1907). The telegraph allowed outside information and foreign ideas to flow. We use distance to the nearest telegraph station as a proxy for the level of access to distant information.

\section{Urbanization:}

Given that many scholars exploit urbanisation as proxy for economic development (Acemoglu, Johnson, \& Robinson, 2002; Kung \& Bai, Forthcoming), even though we do not have exact urbanisation data, we construct, according to Rozman's classic

\footnotetext{
${ }^{219}$ Unequal is a term commonly used by historians to refer to a series of treaties signed by China and certain Western powers during the 19th and early 20th centuries after suffering military defeat. Following the Nanjing treaty, at least 20 unequal treaties in succession were signed, resulting in more ports being designated treaty ports.
} 
classification of Chinese cities, a categorical variable for the size of cities as an alternative, to capture the level of urbanization. Big cities are defined as those with a population of more than 300,000 , that of middle cities lies between 70,000 and 300,000, and that of small cities falls between 30,000 and 70,000 (Rozman, 1973).

\section{Political importance:}

Many writers indicate that the locality's distance from the political centre influences its governance. Counties where the prefectural governments are located in or very near the prefectural seat, may be more prosperous, and tend to conform to the supervision from upper levels of government. Therefore, we add some geographical variables from China's Historical GIS Data to control for the political importance of a given county, including the distance from the prefectural seat, distance from the provincial capital, and two dummy variables: coastal and Yangtze (Bol \& Ge, 2007).

\section{Local protests:}

As discussed in section 4.2.1, the non-obligatory efforts of local government on education progress might be incentivised by corruption. Here, we also include one measurement on the count of local protests as a proxy for local predatory behaviour. $^{220}$

\section{Demographic controls:}

1) County size

2) Population density, which is a potential and widely accepted proxy for initial economic development. ${ }^{221}$

\footnotetext{
${ }^{220}$ The number of protests comes from data transcribed from newspapers; naturally, the special nature of the data source presents quite a high degree of bias, because whether a protest could be reported in the newspapers entirely depended on the information transparency in the given locality.

${ }^{221}$ Much of the literature shows that during Qing China, the population density was still closely associated with the fertility of soil in its locality, which implies that China still remained an agrarian economy, and the development of the agriculture sector held a crucial role.
} 
Table 4.10: Statistical summary of control variables

\begin{tabular}{|c|c|c|c|c|}
\hline Variable Definition & Data & $\mathbf{O b}$ & Mean & S.D. \\
\hline \multicolumn{5}{|l|}{ Agricultural productivity } \\
\hline Soil quality data (rice) & 4 & 1066 & 1.035 & 1.22 \\
\hline Soil quality data (wheat) & 4 & 1066 & 2.788 & 1.21 \\
\hline Agricultural tax quota in Qing dynasty & 3 & 977 & 24.37 & 17.01 \\
\hline \multicolumn{5}{|l|}{ Industrial development } \\
\hline Modern firms & 1 & 1066 & 0.11 & 0.31 \\
\hline Modern Industry location & 1 & 1066 & 0.114 & 0.318 \\
\hline \multicolumn{5}{|l|}{ Population density } \\
\hline Population density_07 (new policy) & 2,3 & 1025 & 1.81 & 2.19 \\
\hline Population density_16 & 2,6 & 1066 & 1.94 & 2.29 \\
\hline Population density_33 & 2 , & 620 & 2.25 & 2.73 \\
\hline \multicolumn{5}{|l|}{ Urbanization level } \\
\hline Population in 1880 & 3 & 1066 & 22.57 & 16.44 \\
\hline Large city $(=1$, if population $>300,000)$ & 5 & 1066 & 0.25 & 0.44 \\
\hline Medium-sized city $(=1$, if $70,000<$ population $<300,000)$ & 5 & 1066 & 0.56 & 0.49 \\
\hline Small city $(=1$, if $30000<$ population $<70,000)$ & 5 & 1066 & 0.13 & 0.34 \\
\hline \multicolumn{5}{|l|}{ Westernization } \\
\hline Treaty port & 7 & 1066 & 0.22 & 0.41 \\
\hline Christians per capita (over 10,000 people) & 6 & 1066 & 8.78 & 17.43 \\
\hline Missionary primary school enrolment ratio & 6 & 1066 & $0.21 \%$ & 0.0053 \\
\hline Nearest distance to county with telegraph & 8 & 1066 & 542.9 & 467.2 \\
\hline \multicolumn{5}{|l|}{ Political geography } \\
\hline Distance to provincial capital & 2 & 1066 & 46.51 & 25.57 \\
\hline Distance to prefectural seat & 2 & 1066 & 170.26 & 101.24 \\
\hline \multicolumn{5}{|l|}{ Local protests } \\
\hline Event counts in newspapers before 1912 & 9 & 1066 & 0.32 & 0.91 \\
\hline \multicolumn{5}{|l|}{ Geographical controls } \\
\hline Coast $(=1$, if located on a coastline) & 2 & 1066 & 0.096 & 0.29 \\
\hline Yangtze River (if 1 , if located by the Yangtze River) & 2 & 1066 & 0.043 & 0.21 \\
\hline
\end{tabular}

*Sources:

1. Chang, Y. (1989). "Private Industries in the Late Ch'ing and the Early Republic of China, 18601916": Bulletin of the Insitute of Modern History, Academia Sinica, 18, 315-561.

2.CHGIS. (2007) Version 4, Harvard Yenching Institute

3.Zhong, Liangfang. (1981). Zhongguo Lidai Hukou Tiandi Tianfu Tongji (Statistics on China's Historical Population, Cultivated land and Land tax). Shanghai: Shanghai Renmin Press

4.FAO.(2012), Global Agro-ecological Zones (GAEZ v3.0)

5.Rozman, G. (1973). Urban Networks in Ch'ing China and Tokugawa Japan. Princeton University Press.

6.Stauffer (1922), The Christian occupation of China: A General Survey of the Numerical Strength and Geographical Distribution of the Christian Forces in China. China Continuation Committee, Shanghai 7.Yan, Zhongping. (1955). Zhongguo Jindai Jingjishi Tongji Ziliao Xuanji (Selected Statistical Materials of Modern China Economic History). Beijing: KeXue Press. 
8.Statistical department of the Inspectorate general of Customs. (1907). Da Qing youzheng gongshu beiyong yutu (China postal working map)

9.Zhenhe Zhang \& Yuanying Ding. (1982) Qingmo Minbian Nianbiao (The History of Civil Conflict in the Late Qing)

\section{Empirical results}

Guided by the previous analysis, this section empirically investigates the driving forces of mass schooling from two perspectives. First, did the strength of the local gentry contribute to the spread of primary education? Second, to what extent did the political turmoil mitigate or increase the effect of the local gentry?

\subsection{Local gentry and the expansion of schooling}

\section{OLS Baseline results:}

Given the difficulty in measuring the variations of the local gentry's strength at county level over time, in this study, the number of local gentry is a cross-sectional variable. Therefore, we first examine the cross-sectional correlations as follows:

$$
\text { Schooling }_{i}=\alpha+{ }^{\gamma} \cdot \text { Gentry }_{i}+X_{i}^{\prime} \theta+\varepsilon_{i}
$$

In Equation 4.1, i represents county; Schooling Sis $_{i}$ a set of variables capturing education development (school density and enrolment ratio); Gentry $y_{i}$ is the variable of interest: the number of local gentry (measured by shengyuan quota, Shengyuan quota per capita and Jinshi per capita); $X_{i}^{\prime}$ indicates economic and geographic controls included; and, $\varepsilon_{i}$ is the error term.

\subsubsection{Local gentry and primary schooling provision}

Table 4.11 features the influences of local gentry on primary schooling provision, which is represented by two different resource input variables, namely primary school density and nominal primary education expenditure per capita. The baseline results show that there is a significant and positive relationship between the quota density of the Shengyuan (lower degree holders) and modern primary school provision through the early $20^{\text {th }}$ century. 
For instance, Columns (1), (3) and (5) show that a county with a higher quota per capita in the Qing dynasty enjoyed significantly better primary school density after controlling for only certain basic county characteristics, including population density, county size and provincial dummies. Adding more control variables to do with county economic characteristics and political importance does not alter the conclusion that the number of local gentry, as measured by quota density in the Qing era, had the effect of significantly increasing primary education provision in the three benchmark years.

Concerning magnitude, presented in Column (2), Column (4) and Column (6), the effects of gentry are noticeable. In 1907, one standard deviation increase (1.58) in the quota density in the Qing raises the number of primary schools for 10,000 people by $0.91(1.58 * 0.58)$ data points. Given that the mean of primary school density in 1907 was 1.34 , this effect of the gentry quota alone accounts for $68 \%(0.91 / 1.34)$ of the average primary school density. Similarly, in 1916, one standard deviation increase in quota density is associated with a $23.54 \%$ increase in primary school density, when evaluated at the mean (1.15/4.9). In addition, the effect accounts for $11 \%$ of the overall primary school density in $1933(0.97 / 8.9)$.

When employing expenditure per capita as the indicator for primary schooling provision, Columns (7) - (10) show results that are consistent with the findings above. The nature of the gentry's effect on primary education expenditure is far from trivial. In 1916, the gentry quota density could explain $10 \%$ of the expenditure that was spent on primary schooling per capita, evaluated at the mean; similarly, the gentry's effect explains 18\% of the primary schooling expenditure in 1933. 
Table 4.11: Correlation between primary schooling provision and gentry

\begin{tabular}{|c|c|c|c|c|c|c|}
\hline & \multicolumn{6}{|c|}{ Primary school density over 10,000 people } \\
\hline & \multicolumn{2}{|c|}{1907} & \multicolumn{2}{|c|}{1916} & \multicolumn{2}{|c|}{1930} \\
\hline & $(1)$ & $(2)$ & (3) & $(4)$ & $(5)$ & $(6)$ \\
\hline \multirow{2}{*}{ Local gentry } & 0.72 & 0.58 & 1.02 & 0.73 & 0.75 & 0.62 \\
\hline & $(0.14)^{* * *}$ & $(0.001)^{* * *}$ & $(0.2)^{* * *}$ & $(0.17)^{* * *}$ & $(0.31)^{* *}$ & $(0.39)^{*}$ \\
\hline Population & 0.028 & 0.014 & -0.063 & -0.036 & -0.57 & -0.57 \\
\hline Density & $(0.019)$ & $(0.035)$ & $(0.036)^{*}$ & $(0.05)$ & $(0.14)^{* *}$ & $(0.16)^{* *}$ \\
\hline Other & NO & YES & NO & YES & NO & YES \\
\hline Province FE & YES & YES & YES & YES & YES & YES \\
\hline Observations & 904 & 904 & 1066 & 1066 & 599 & 599 \\
\hline \multirow[t]{4}{*}{ R-squared } & 0.38 & 0.43 & 0.39 & 0.43 & 0.58 & 0.61 \\
\hline & & & \multicolumn{4}{|c|}{ Primary schooling expenditure per capita } \\
\hline & & & \multicolumn{2}{|c|}{1916} & \multicolumn{2}{|c|}{1930} \\
\hline & & & (7) & $(8)$ & (9) & $(10)$ \\
\hline \multirow{2}{*}{ Local gentry } & & & 0.007 & 0.0052 & 0.021 & 0.039 \\
\hline & & & $(0.0018)^{* * *}$ & $(0.0025)^{* *}$ & $(0.0076)^{* * *}$ & $(0.009)^{* * *}$ \\
\hline Population & & & 0.0014 & -0.0019 & -0.0053 & -0.011 \\
\hline Density & & & $(0.0013)$ & $(0.0034)$ & $(0.0019)^{* * *}$ & $(0.0024)^{* * *}$ \\
\hline Other Controls & & & NO & YES & NO & YES \\
\hline Province FE & & & YES & YES & YES & YES \\
\hline Observations & & & 1066 & 1066 & 386 & 386 \\
\hline R-squared & & & 0.07 & 0.11 & 0.7 & 0.77 \\
\hline
\end{tabular}

Note:

(i). In this table, the numbers of local gentry are based on the shenyuan quota density ( normalised by 1907 population)

(ii). Control variables include: potential soil quality for rice, late Qing land tax quota, modern industry location dummy, treaty port dummy, density of Christians over 10000 people, distance to nearest telegraph station, distance to prefectural seat, distance to provincial capital, dummy for Yangtze river, dummy for coastal area.

(iv). All the standard errors are clustered at county level in parentheses. * significant at $10 \%$; ** significant at $5 \%$; *** significant at $1 \%$

\subsubsection{Local gentry and primary enrolment}

Table 4.12 shifts our attention from the effect of local gentry on primary school provision to its effects on enrolment ratios. Consistent with the results on educational provision, we find that there is a significant and positive relationship between the quota density of lower degree holders and the primary enrolment ratio, with few basic controls; adding a list of more control variables on economic development does not change the qualitative conclusion. In terms of magnitude, Columns (2), (4) and (6) show that one standard deviation increase in quota per capita (1.58) in the Qing period for a given county was associated in 1907with a 0.88 percentage points increase in the primary enrolment ratio $(1.58 * 0.56)$, and this effect accounts for $47 \%$ of the average primary enrolment ratios $(0.88 / 1.9)$ in the same year. 
The magnitude of the gentry's impact dropped to $11 \%$ in 1916 ; while for the year 1933 the gentry effect is no longer significant.

Table 4.12: Correlation between primary schooling level and gentry

\begin{tabular}{|c|c|c|c|c|c|c|}
\hline & \multicolumn{6}{|c|}{ Primary enrolment ratio } \\
\hline & \multicolumn{2}{|c|}{1907} & \multicolumn{2}{|c|}{1916} & \multicolumn{2}{|c|}{1930} \\
\hline & (1) & (2) & (3) & (4) & (5) & (6) \\
\hline \multirow{2}{*}{ Local gentry } & 0.0075 & 0.0056 & 0.006 & 0.0046 & 0.004 & 0.0043 \\
\hline & $(0.0015)^{* * * *}$ & $(0.0011)^{* * * *}$ & $(0.0018)^{* * *}$ & $(0.002)^{*}$ & $(0.005)$ & $(0.007)$ \\
\hline Population & 0.00028 & -0.00002 & 0.0012 & -0.00069 & -0.008 & -0.009 \\
\hline Density & $(0.00029)$ & $(0.0004)$ & $(0.0008)$ & $(0.0012)$ & $(0.002)^{* * *}$ & $(0.003)^{* * *}$ \\
\hline Controls & NO & YES & NO & YES & $\mathrm{NO}$ & YES \\
\hline Province FE & YES & YES & YES & YES & YES & YES \\
\hline Observations & 904 & 904 & 1140 & 1140 & 599 & 599 \\
\hline R-squared & 0.3 & 0.39 & 0.34 & 0.37 & 0.52 & 0.57 \\
\hline
\end{tabular}

Notes:

(i). The numbers of local gentry are based on the shenyuan quota density (normalised by the late Qing population) (ii). Control variables include: potential soil quality for rice cultivation, late Qing land tax quota, modern industry location dummy, treaty port dummy, density of Christians over 10000 people, distance to nearest telegraph station, distance to prefectural seat, distance to provincial capital, dummy for Yangtze river, dummy for coastal area.

(iii). All the standard errors are clustered at county level in parentheses. * significant at $10 \%$; $*$ significant at $5 \%$; *** significant at $1 \%$

Comparing Tables 4.11 and 4.12, we find that the gentry had a persistent effect on primary schooling provision, consistent with the discussions above on the roles of different interest groups. But when we examine the gentry's effect on education outcomes, it fades by the 1930s. As discussed, the schooling outcome is decided by both demand and supply; more importantly, they interact with each other, making it difficult to disentangle the separate effects. When schooling provision increases rapidly within a short period as a supply shock, we can assume that the educational outcome is largely determined by the factors that influence education supply. This is why, in the first few decades after modern schooling was promoted, the role of the gentry, which helps explain schooling provision, also explains the enrolment ratio. But after almost four decades of public modern primary schooling provision, the school density had passed the tipping point where it no longer represented an exogenous supply shock. This means that demand side factors, such as economic structure, begin to play a stronger role in determining schooling attainment, once the primary schooling expansion was self-sustaining. 


\subsubsection{Dynamic effects of local gentry:}

The baseline estimate focuses on the impact of gentry on schooling. If we pool the three cross-sections together, we can also examine how the gentry's effect on schooling changed over time. The specification is as follows:

Schooling $_{i}=\alpha+\gamma \cdot$ Gentry $_{i}+\beta \cdot$ Time $_{r}+\delta \cdot$ Time $_{r} \times$ Gentry $_{i}+X_{i}^{\prime} \theta+\varepsilon_{i}(4.2)$ where the year 1907 is left for comparison.

Overall, the results in Table 4.13 also confirm the close correlation between the role of the gentry (the Shengyuan quota) and primary schooling development through the early $20^{\text {th }}$ century. But the spread of schools per capita and the outcomes are largely explained by time dummies. More importantly, the results also show a significant difference in the impact of the gentry on schooling variables year by year, and it is clear that the impact of the gentry declines markedly over time. Starting with the schooling provision, the size of the impact of gentry on school density is around $42 \%$ in 1907 , drops to $12.6 \%$ in 1916 , and rises to $15.4 \%$ in 1933 . These results are very similar to the baseline estimates in Table 4.11. For schooling outcomes, the size of the gentry effect is $23.7 \%$ in 1907 , and falls again to $5.4 \%$ in 1916 then settling at $8.9 \%$ in 1933.

In summary, , the baseline cross-sectional results and pooled estimations both show that counties with a higher quota density tend in the early $20^{\text {th }}$ century to have both better primary education provision and better schooling outcomes. Two important implications can be drawn from the results. First, regarding education provision alone, the gentry mattered more in the early stages, when the primary schools were very scarce; once schooling expansion was more self-sustaining, the role of the gentry declined. Furthermore, the gentry presented a much stronger effect on the schooling provision than on the enrolment ratios, which also corresponds with our previous analysis that the gentry actively engaged in the decision making process regarding schooling provision; whereas how enthusiastically the populace responded to the increasing number of modern primary schools was associated with many other factors. 
Table 4.13: Dynamic effects of local gentry on primary education

\begin{tabular}{|c|c|c|c|c|}
\hline & \multicolumn{2}{|c|}{ Primary school density } & \multicolumn{2}{|c|}{ Primary enrolment ratio } \\
\hline & (1) & (2) & (3) & (4) \\
\hline \multirow{2}{*}{ Local gentry } & 0.062 & 0.058 & 0.0011 & 0.000089 \\
\hline & $(0.007)^{* * *}$ & $(0.008)^{* * *}$ & $(0.0001)^{* * *}$ & $(0.0002)^{* * *}$ \\
\hline \multirow{2}{*}{ T_1916 } & 4.9 & 4.9 & 0.095 & 0.094 \\
\hline & $(0.43)^{* * *}$ & $(0.39)^{* * *}$ & $(0.004)^{* * *}$ & $(0.005)^{* * *}$ \\
\hline \multirow{2}{*}{ T_1933 } & 10.2 & 10.5 & 0.22 & 0.22 \\
\hline & $(0.86) * * *$ & $(0.8)^{* * *}$ & $(0.013)^{* * *}$ & $(0.015)^{* * *}$ \\
\hline \multirow{2}{*}{ Gentry*Year 1916} & -0.059 & -0.059 & -0.0008 & -0.00078 \\
\hline & $(0.009)^{* * *}$ & $(0.0092)^{* * *}$ & $(0.0001)^{* * *}$ & $(0.0001)^{* * *}$ \\
\hline \multirow{2}{*}{ Gentry*Year 1933} & -0.13 & -0.16 & -0.0014 & -0.0017 \\
\hline & $(0.018)^{* * *}$ & $(0.022)^{* * *}$ & $(0.0004)^{* * *}$ & $(0.0005)^{* * *}$ \\
\hline \multirow{2}{*}{ Population Density } & -0.28 & -0.38 & -0.0041 & -0.0067 \\
\hline & $(0.044)^{* * *}$ & $(0.063)^{* * *}$ & $(0.0009)^{* * *}$ & $(0.0009)^{* * *}$ \\
\hline \multirow{2}{*}{ Potential Agriculture Yield } & & -0.06 & & 0.0011 \\
\hline & & $(0.087)$ & & $(0.0043)$ \\
\hline \multirow{2}{*}{ Landtax Quota (Qing) } & & 0.035 & & -0.00067 \\
\hline & & $(0.005)^{* * *}$ & & $(0.00012)^{* * *}$ \\
\hline \multirow{2}{*}{ Modern Industry } & & 0.17 & & 0.016 \\
\hline & & $(0.25)$ & & $(0.006)^{* *}$ \\
\hline \multirow{2}{*}{ Treaty Port } & & 0.64 & & 0.015 \\
\hline & & $(0.38)^{* *}$ & & $(0.0053)^{* * *}$ \\
\hline \multirow{2}{*}{ Christianity Density } & & 152.9 & & 2.55 \\
\hline & & $(61.2)^{* *}$ & & -1.6 \\
\hline \multirow{2}{*}{ Distance to Telegraph } & & -0.75 & & -0.007 \\
\hline & & $(0.23)^{*}$ & & $(0.0039)^{* *}$ \\
\hline \multirow{2}{*}{ Distance to Prefecture-seat } & & -0.014 & & -0.00025 \\
\hline & & $(0.005)^{* *}$ & & $(0.0001)^{* * *}$ \\
\hline \multirow{2}{*}{ Distance to Provincial capital } & & 0.003 & & 0.00005 \\
\hline & & $(0.001)^{* *}$ & & $(0.00002)^{* *}$ \\
\hline \multirow{2}{*}{ Local Protests } & & 0.091 & & -0.0027 \\
\hline & & -0.1 & & -0.0024 \\
\hline Geo Control & $\mathrm{NO}$ & YES & $\mathrm{NO}$ & YES \\
\hline Province FE & YES & YES & YES & YES \\
\hline Observations & 2701 & 2701 & 2701 & 2701 \\
\hline R-squared & 0.5 & 0.54 & 0.54 & 0.57 \\
\hline
\end{tabular}

Notes:

i. In this table, the numbers of local gentry were based on the shenyuan quota

ii. Control variables include: potential soil quality for rice cultivation, late Qing land tax quota, modern industry location dummy, treaty port dummy, density of Christians over 10,000 people, distance to nearest telegraph station, distance to prefectural seat, distance to provincial capital, dummy for Yangtze river, dummy for coastal area.

iii. All the standard errors clustered at county level in parentheses. * significant at $10 \%$; ** significant at $5 \%$; *** significant at $1 \%$. 


\subsection{Instrumented evidence: the gentry's effect on primary schooling}

The persistently close correlation between local gentry and primary schooling displayed in the previous section should not be interpreted as causal, for several reasons. First, the quota numbers for Shengyuan were not randomly assigned across regions. The figure is believed to be closely associated with the size of the county and its economic importance (C. Chang, 1955, pp. 77-79); and many omitted variables associated with economic prosperity are correlated in history with the number of local gentry. For this reason, the gentry's influence on primary schooling captured in the simple OLS estimations could be due to the channel of unobserved economic performance, rather than the reasons provided in section 3.2. Another potential problem lies in the measurement error in the proxy for gentry power. This is because instead of the actual number of gentry members in the period we use the quota numbers assigned in the late Qing period as a proxy for the local gentry's power in the Republican era. To address these concerns, and to rigorously test the gentry's causal effect on primary education expansion, an instrument variable strategy is applied in this section. Such an instrument must be an important factor in accounting for the gentry (Shengyuan's quota) number variation, but must have no direct effect on economic performance.

\section{Instrument: a sudden change in quota numbers owing to the Taiping Rebellion}

In this section, we employ the sudden increase in regional quotas of lower degree holders (Shengyuan) triggered by the Taiping Rebellion (1850-1864) as an instrumental variable for quota density.

The county level quotas for the lowest level scholars (shengyuan) remained very stable for most of the time during the Qing period, and the figures increased substantially only because of the outbreak of the Taiping Rebellion. The magnitude of the increase in the quota was associated neither with the original quota number nor the level of economic development. According to the Imperially Established Institutes and Laws of the Great Qing Dynasty (大清会典), larger quotas were granted to disruptive regions as an incentive to extract taxes from localities; or extra quotas were allocated as rewards to the hometowns of those magistrates who successfully 
organised military forces against rebels during the Taiping Rebellion (C. Chang, 1955, pp. 83-92; Kun, 1899).222

\subsubsection{Falsification tests:}

Even though extra quotas were set at times of political disruption rather than as economic rewards, the regions most affected during the Taiping Rebellion were located in the most prosperous South East of China(P. A. Kuhn, 1978). ${ }^{223}$ Therefore, the exclusion restriction is likely to hold. In order to confirm our instrument variable as valid, several falsification tests were performed. To do so, we needed to prove that the instrument variable should not affect the indicators of economic development.

Figure 4.4: change of quota vs. economic factors

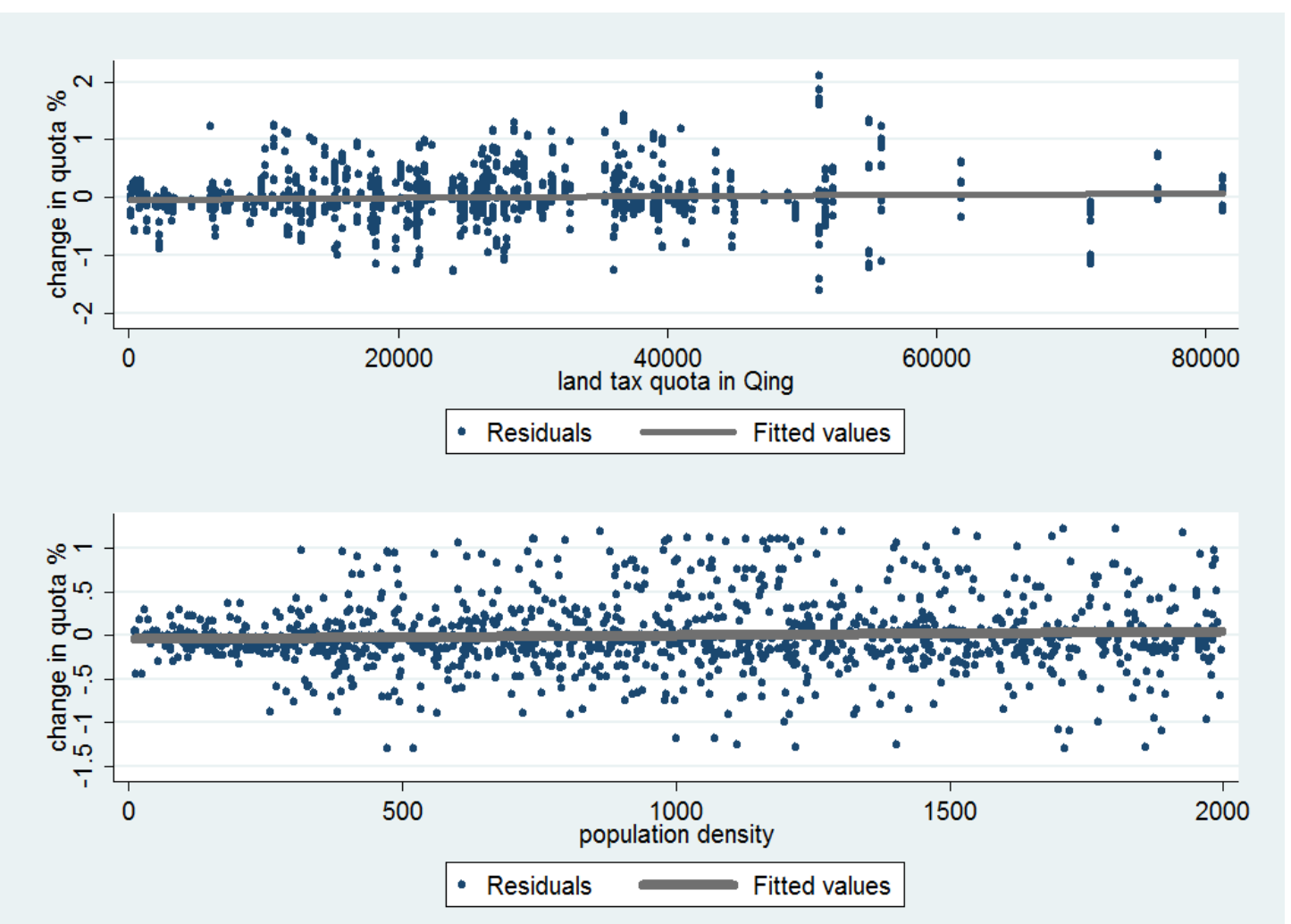

Note: $\mathrm{Y}$ is the residual of regression of the percentage of change of Shengyuan quota in total on all the control variables used in the baseline specification.

${ }^{222}$ Larger quotas were granted to the hometown of the magistrate instead of the locality of his service, which makes the increase in quotas across regions more random.

${ }^{223}$ The Taiping rebellion began in the province of Guangxi, but quickly came to control the prosperous coastal provinces of China, including Jiangsu, Zhejiang, and part of Anhui, and established the Taiping 'Heavenly Capital' in the city of Nanking (P. A. Kuhn, 1978). 
In Table 4.14, we present the effects of our instrument variable on indicators for economic characteristics. The results consistently show that the sudden change in quota number was not statistically correlated with these economic variables. Furthermore, the effect of a sudden change in quota on the final quota density is strongly significant.

Table 4.14: Falsification tests: the effect of instrument on other variables

\begin{tabular}{lcc|ccccc}
\hline & $\begin{array}{c}\text { Quota } \\
\text { number }\end{array}$ & $\begin{array}{c}\text { Quota } \\
\text { density }\end{array}$ & $\begin{array}{c}\text { Potential } \\
\text { Agriculture } \\
\text { Yield }\end{array}$ & $\begin{array}{c}\text { Landtax } \\
\text { Quota }\end{array}$ & $\begin{array}{c}\text { Treaty } \\
\text { Port }\end{array}$ & $\begin{array}{c}\text { Modern } \\
\text { Industry }\end{array}$ & Telegraph \\
\cline { 2 - 8 } Change percent & 10.4 & 0.78 & 0.042 & 0.01 & 0.76 & 0.212 & 0.009 \\
& $(0.82)^{* * *}$ & $(0.08)^{* * *}$ & -0.065 & -0.32 & -0.14 & -0.33 & -0.026 \\
Controls & YES & YES & YES & YES & YES & YES & YES \\
Observations & 904 & 904 & 904 & 904 & 904 & 904 & 904 \\
R-squared & 0.66 & 0.61 & 0.67 & 0.52 & 0.35 & 0.37 & 0.32 \\
\hline \multirow{7}{*}{ Change percent } & 10.5 & 1.32 & 0.037 & -0.0026 & -0.21 & 0.108 & 0.032 \\
\cline { 2 - 8 } Controls & $(1.02)^{* * *}$ & $(0.06)^{* * *}$ & -0.076 & -0.003 & -0.23 & -0.35 & -0.028 \\
Observations & 1140 & 1140 & 1140 & 1140 & 1140 & 1140 & 1140 \\
R-squared & 0.66 & 0.49 & 0.67 & 0.45 & 0.35 & 0.37 & 0.32 \\
\hline \multirow{7}{*}{ Change percent } & 13.27 & 0.63 & 0.041 & 0.0012 & 0.01 & -0.033 & 0.002 \\
\cline { 2 - 8 } Controls & $(2.1)^{* * *}$ & $(0.13)^{* * *}$ & -0.032 & -0.002 & -0.33 & -0.027 & -0.003 \\
Observations & 599 & 599 & 599 & 599 & 599 & 599 & 599 \\
R-squared & 0.7 & 0.67 & 0.69 & 0.52 & 0.3 & 0.36 & 0.17 \\
\hline \hline
\end{tabular}

Note: All the standard errors clustered at county level are shown in parentheses. * significant at $10 \%$; ** significant at $5 \%$; *** significant at $1 \%$

The falsification tests displayed in Table 4.14 suggest that the sudden change in quotas of Shengyuan owing to the Taiping Rebellion is a plausible instrument for quota density. Moreover, by employing this identification strategy, we can establish the causal links between the strength of the local gentry and the expansion of primary schooling through the early $20^{\text {th }}$ century. 


\subsubsection{The causal effect of the gentry on primary schooling}

To further identify the causal effect of gentry strength on primary schooling, Table 4.15 presents the two-stage least-squares estimates. Columns (7)-(12) display 2SLS estimates of the coefficient of interest, with and without controls, and Columns (1)-(6) present corresponding first stage results. To begin with, Columns (1)-(6) display the close first-stage relationship between change of the Shengyuan quota and the quota numbers in the late Qing period. The corresponding 2SLS estimates of the impact of the gentry on school density and enrolment ratios are significantly positive across years, which is consistent with our baseline results in the previous section. However, unlike the findings in Tables 4.11 and 4.12 that the coefficients of the local gentry decrease substantially after adding in the control variables, in the IV results, the coefficients stay quite stable after controlling for other economic indicators; with the exception of 1933, when the independent variable is primary school density. These are encouraging results, implying that the instrumented local gentry density remains stable with the inclusion of other potential codeterminants of primary schooling expansion.

Concerning school provision, first, the IV coefficients for the variable of interest are only slightly smaller than the results from baseline regressions. For instance, one standard deviation increase in quota density in the Qing period causes primary school density to increase by 0.37 data points $\left(1.58^{*} 0.24\right)$; evaluated at the mean, this effect accounts for $29.16 \%$ (0.38 /1.3) of overall density in 1907. The effects for 1916 and 1933 are $15.1 \%$ and $6.56 \%$ respectively. Comparing these results with those in Table 4.11 (68\% in 1907, 23.54\% in 1916, $11 \%$ in 1933), the IV estimates suggest the possibility that the baseline estimators are subject to an upward bias.

Table 4.15: Estimation results from IV strategy

\begin{tabular}{|c|c|c|c|c|c|c|}
\hline \multicolumn{7}{|c|}{ First stage } \\
\hline & \multicolumn{2}{|c|}{1907} & \multicolumn{2}{|c|}{1916} & \multicolumn{2}{|c|}{1930} \\
\hline & (1) & (2) & (3) & (4) & (5) & (6) \\
\hline \multirow{2}{*}{ Change in quota } & 1.46 & 1.49 & 0.48 & 0.39 & 0.023 & 0.043 \\
\hline & $(0.042)^{* * *}$ & $(0.036)^{* * *}$ & $(0.22)^{* * *}$ & $(0.18)^{* *}$ & $(0.008)^{* * *}$ & $(0.009)^{* *}$ \\
\hline Control & Yes & Yes & Yes & Yes & Yes & Yes \\
\hline Province FE & No & Yes & No & Yes & No & Yes \\
\hline Observations & 876 & 876 & 909 & 909 & 532 & 532 \\
\hline $\mathrm{R}$-squared & 0.58 & 0.71 & 0.56 & 0.62 & 0.58 & 0.64 \\
\hline
\end{tabular}




\begin{tabular}{|c|c|c|c|c|c|c|}
\hline & \multicolumn{6}{|c|}{ Second stage: the dependent variable is the enrolment ratio } \\
\hline & \multicolumn{2}{|c|}{1907} & \multicolumn{2}{|c|}{1916} & \multicolumn{2}{|c|}{1930} \\
\hline & (7) & $(8)$ & (9) & $(10)$ & $(11)$ & (12) \\
\hline \multirow{2}{*}{ Local Gentry } & 0.0053 & 0.0061 & 0.016 & 0.014 & 0.098 & 0.043 \\
\hline & $(0.002)^{* *}$ & $(0.0034)^{* *}$ & $(0.006)^{* * *}$ & $(0.006) * * *$ & $(0.06)^{*}$ & $(0.018)^{* *}$ \\
\hline Control & No & Yes & No & Yes & No & Yes \\
\hline Province FE & Yes & Yes & Yes & Yes & Yes & Yes \\
\hline Observations & 876 & 876 & 909 & 909 & 532 & 532 \\
\hline \multirow[t]{4}{*}{ R-squared } & 0.29 & 0.36 & 0.29 & 0.35 & 0.07 & 0.54 \\
\hline & \multicolumn{6}{|c|}{ Second stage: the dependent variable is school density over 10,000} \\
\hline & \multicolumn{2}{|c|}{1907} & \multicolumn{2}{|c|}{1916} & \multicolumn{2}{|c|}{1930} \\
\hline & (13) & $(14)$ & $(15)$ & (16) & $(17)$ & (18) \\
\hline \multirow{2}{*}{ Local Gentry } & 0.22 & 0.24 & 0.48 & 0.47 & 0.34 & 0.37 \\
\hline & $(0.12)^{*}$ & $(0.13)^{*}$ & $(0.22)^{* *}$ & $(0.023)^{* *}$ & -1.06 & $(0.19)^{* *}$ \\
\hline Control & No & Yes & No & Yes & No & Yes \\
\hline Province FE & Yes & Yes & Yes & Yes & Yes & Yes \\
\hline Observations & 876 & 876 & 909 & 909 & 532 & 532 \\
\hline R-squared & 0.37 & 0.41 & 0.38 & 0.36 & 0.58 & 0.61 \\
\hline
\end{tabular}

(i). The numbers of local gentry are based on the shenyuan quota, normalised by 1907 population

(ii). Control variables include: potential soil quality for rice, late Qing land tax quota, modern industry location dummy, treaty port dummy, density of Christians over 10000 people, distance to nearest telegraph station, distance to prefectural seat, distance to provincial capital, dummy for Yangtze river, dummy for coastal area.

(iii). All the standard errors clustered at county level in parentheses.* significant at $10 \%$; ** significant at $5 \%$; *** significant at $1 \%$

When we change our independent variable to the primary enrolment ratio, the estimates show consistent results. A standard deviation increase in quota density raises primary enrolment ratios by 1.01 percentage points $(0.0053 * 1.58)$; given that the mean of primary enrolment ratio in 1907 is $1.9 \%$, this effect explains $44.07 \%$ of the primary enrolment ratios in China (0.83/1.9). Consistently, the explanatory effect of the gentry's role on primary enrolment ratios declines to $23.9 \%$ in 1916 $(0.014 * 1.58 / 0.094)$, and reaches $30.8 \%$ in 1933 . Again, comparing these results with those in Table 4.12 (46.5\% in 1907, 10.6\% in 1916; no effect in 1933), it is apparent that, for the latter time periods, 1916 and 1933, the IV result is considerably larger than the baseline result. This pattern suggests that the bias of OLS estimates is at a late stage of educational development when the economic characteristics, which are 
also correlated with the quota numbers of Shengyuan in the late Qing, had stronger effects on the level of schooling.

Table 4.16: Dynamic effect of the local gentry on primary education

\begin{tabular}{lcc|cc}
\hline & \multicolumn{2}{c|}{ Primary School Density } & \multicolumn{2}{c}{ Primary Enrolment Ratio } \\
\hline & OLS & IV & OLS & IV \\
\hline Local gentry & 0.062 & 0.076 & 0.0011 & 0.0018 \\
& $(0.007)^{* * *}$ & $(0.022)^{* * *}$ & $(0.0001)^{* * *}$ & $(0.0007)^{* * *}$ \\
Year 1916 & 4.9 & 4.8 & 0.095 & 0.089 \\
& $(0.43)^{* * *}$ & $(0.39)^{* * *}$ & $(0.004)^{* * *}$ & $(0.007)^{* * *}$ \\
Year 1933 & 10.2 & 10.5 & 0.22 & 0.17 \\
& $(0.86)^{* * *}$ & $(0.8)^{* * *}$ & $(0.013)^{* * *}$ & $(0.021)^{* * *}$ \\
Gentry*Year 1916 & -0.059 & -0.047 & -0.0008 & -0.0006 \\
& $(0.009)^{* * *}$ & $(0.017)^{* * *}$ & $(0.0001)^{* * *}$ & -0.0004 \\
Gentry *Year 1933 & -0.13 & -0.078 & -0.0014 & -0.0026 \\
Control & $(0.018)^{* * *}$ & $(0.034)^{* * *}$ & $(0.0004)^{* * *}$ & $(0.0009)^{* * *}$ \\
Province FE & NO & YES & NO & YES \\
\hline Observations & YES & YES & YES & YES \\
R-squared & 2701 & 2701 & 2701 & 2701 \\
\hline \hline
\end{tabular}

Notes:

(i). In this table, the numbers of local gentry are based on the shenyuan quota.

(ii). Control variables include: potential soil quality for rice cultivation, late Qing land tax quota, modern industry location dummy, treaty port dummy, density of Christian over 10000 people, distance to nearest telegraph station, distance to prefectural seat, distance to provincial capital, dummy for Yangtze river, dummy for coastal area.

(iii). All the standard errors clustered at county level are shown in in parentheses.

* significant at $10 \%$;* significant at $5 \%$; ** significant at $1 \%$

\subsubsection{Robustness}

One of the main potential weaknesses of our estimates lies in the crude nature of the control variables for economic performance. The validity of our IV results depends on the assumption that the changes of quota due to the Taiping Rebellion have no direct effect on economic performance. While falsification tests using a list of economic indicators support this assumption, many other economic conditions cannot be examined, due to the lack of available data. Therefore, in this section, we shrink our sample to only one province-Shanxi (94 counties), ${ }^{224}$ where detailed relevant statistics are available, thanks to several social surveys that were carried out under the

\footnotetext{
${ }^{224}$ Historically, Shanxi was not an educationally advanced province. In terms of Jinshi numbers, those who came from Shanxi province account for only $5.46 \%$ of the national figure; while a province such as Jiangsu contributed more than $15 \%$.
} 
rule of Yan(Shanxisheng Dijiuci Jingji Tongji Zhengji (The eonomic survey of Shanxi Province 9th), 1927). These variables include actual agricultural output, living expenses, etc. The positive correlation between the Shengyuan quota and primary schooling variables stay persistently close after more control variables are added in.

In addition, to minimize measurement error, we employed different indicators as proxies for the number of local gentry as a robustness check. For instance, we used the absolute quota figure through the late Qing period and the quota number normalised by county size; with both indicators providing strikingly similar results, showing a significantly positive relationship between the local gentry in the Qing era and primary schooling through the Republican era.

Table 4.17: Robustness check using Shanxi Province

\begin{tabular}{lccc}
\hline & School Density & Expenditure per capita & Enrolment Ratio \\
\hline & 0.19 & 0.16 & 0.48 \\
& $(0.78)^{* *}$ & $(0.094)^{*}$ & $(0.25)^{* *}$ \\
\hline Control & YES & YES & YES \\
Observations & 94 & 94 & 94 \\
R-squared & 0.44 & 0.28 & 0.27 \\
\hline \hline
\end{tabular}

Notes:

(i). In this table, the numbers of local gentry are based on the shenyuan quota density

(ii). Control variables include: average productivity per mu, average cost of living, late Qing land tax quota, modern industry location dummy, treaty port dummy, density of Christian over 10000 people, distance to nearest telegraph station, distance to prefectural seat, distance to provincial capital, dummy for Yangtze river, dummy for coastal area.

(iii). All the standard errors clustered at prefecture level are shown in in parentheses.

* significant at $10 \%$;* significant at $5 \%$; *** significant at $1 \%$

\subsection{Political instability and the role of the gentry}

Our previous specification only considers the role of local gentry; now, we turn to examining whether political stable regions enjoyed better provision of public goods. More importantly, we are also interested in testing whether the link between the strength of local gentry and schooling development is different for politically stable and for chaotic regions.

The main challenge is in constructing a valid measure for the strength of political instability in a county. Information on county magistrate turnover is used, and is calculated on the average length of a magistrate's tenure in office for a given county. 
As such information are not available in all counties' gazetteers, the sample shrinks considerably after adding this variable to our specification. Specification and preliminary results:

$$
\text { Schooling }_{i}=\alpha+\beta \cdot p_{i}+\gamma \cdot G+\eta \cdot p_{i} \cdot G+X_{i}^{\prime} \theta+\varepsilon_{i} n
$$

In Equation 4.3, i represents county, and $p_{i}$ is the key variable of interest, political stability; $\mathrm{G}$ is the strength of the local gentry during the Qing dynasty; then we also include their interaction term, economic and geographic controls $X_{i}^{\prime}$ and $\varepsilon_{i}$ which is the error term.

Table 4.18: Dependent variable: primary enrolment ratios

\begin{tabular}{|c|c|c|c|c|}
\hline & \multicolumn{4}{|c|}{ Primary Enrolment Ratio } \\
\hline & \multicolumn{2}{|c|}{1916} & \multicolumn{2}{|c|}{1933} \\
\hline & OLS & IV & OLS & IV \\
\hline Local gentry & $\begin{array}{c}0.016 \\
(0.006)^{* * *}\end{array}$ & $\begin{array}{c}0.058 \\
(0.008)^{* * *}\end{array}$ & $\begin{array}{c}0.105 \\
(0.032)^{* * *}\end{array}$ & $\begin{array}{l}0.069 \\
(3.4)^{*}\end{array}$ \\
\hline Tenure as magistrate & $\begin{array}{c}0.11 \\
(0.006)^{*}\end{array}$ & $\begin{array}{c}0.075 \\
(0.029)^{* * *}\end{array}$ & $\begin{array}{c}0.12 \\
(0.03)^{* * *}\end{array}$ & $\begin{array}{c}0.058 \\
(0.012)^{* * *}\end{array}$ \\
\hline Gentry $*$ Magistrates & $\begin{array}{c}-0.031 \\
(0.0013) * *\end{array}$ & $\begin{array}{l}-0.029 \\
(0.01)^{*}\end{array}$ & $\begin{array}{r}-0.041 \\
-0.032 \\
\end{array}$ & $\begin{array}{c}-0.023 \\
(0.0046) * * * \\
\end{array}$ \\
\hline $\begin{array}{l}\text { Controls } \\
\text { FE province } \\
\text { Observations } \\
\text { R-squared }\end{array}$ & $\begin{array}{l}\text { Yes } \\
\text { Yes } \\
581 \\
0.45 \\
\end{array}$ & $\begin{array}{l}\text { Yes } \\
\text { Yes } \\
581 \\
0.41 \\
\end{array}$ & $\begin{array}{l}\text { Yes } \\
\text { Yes } \\
462 \\
0.32 \\
\end{array}$ & $\begin{array}{l}\text { Yes } \\
\text { Yes } \\
462 \\
0.34 \\
\end{array}$ \\
\hline \multirow{3}{*}{ R-squared } & \multicolumn{4}{|c|}{ Primary School Density } \\
\hline & \multicolumn{2}{|c|}{1916} & \multicolumn{2}{|c|}{1933} \\
\hline & OLS & IV & OLS & IV \\
\hline Local gentry & $\begin{array}{c}0.162 \\
(0.05)^{* * *}\end{array}$ & $\begin{array}{c}0.149 \\
(0.05)^{* * *}\end{array}$ & $\begin{array}{c}2.14 \\
(0.93)^{* *}\end{array}$ & $\begin{array}{c}1.59 \\
(0.067)^{* *}\end{array}$ \\
\hline Tenure as magistrate & $\begin{array}{c}0.042 \\
(0.026)^{* *}\end{array}$ & $\begin{array}{c}0.103 \\
(0.059)^{*}\end{array}$ & $\begin{array}{c}0.37 \\
(0.153)^{*}\end{array}$ & $\begin{array}{c}0.41 \\
(0.192)^{* * *}\end{array}$ \\
\hline Gentry * Magistrate & $\begin{array}{c}-0.017 \\
(0.009) *\end{array}$ & $\begin{array}{c}-0.035 \\
(0.002)^{*}\end{array}$ & $\begin{array}{c}-0.129 \\
(0.077)^{*}\end{array}$ & $\begin{array}{c}-0.146 \\
(0.084)^{*}\end{array}$ \\
\hline Controls & Yes & Yes & Yes & Yes \\
\hline FE province & Yes & Yes & Yes & Yes \\
\hline Observations & 581 & 581 & 462 & 462 \\
\hline R-squared & 0.45 & 0.41 & 0.67 & 0.67 \\
\hline
\end{tabular}

\section{Notes:}

(i). In this table, the numbers of local gentry are based on the shenyuan quota density, normalised by 1907 county population

(ii). Control variables include: potential soil quality for rice cultivation, late Qing land tax quota, modern industry location dummy, treaty port dummy, density of Christians over 10000 people, distance to nearest telegraph station, distance to prefectural seat, distance to provincial capital, dummy for Yangtze river, dummy for coastal area.

(iii). All the standard errors clustered at county level are shown in parentheses. * significant at $10 \%$; ** significant at $5 \%$;** significant at $1 \%$. 
The main results are presented in Table 4.17. All estimations include all the control variables used in the previous specifications. Simple OLS and IV estimates show that the effect of the length of a magistrate's tenure is positive, and interacting it with gentry density results in a significant and positive impact on the primary schooling enrolment ratio $(0.075-0.029 * 1.22=0.039)$. It confirms the assumption that political stability results in higher accountability. For instance, the primary enrolment ratio rises by 0.039 data points, when the tenure of a magistrate increases by one year $(0.075-1.22 * 0.029)$. Evaluated at the mean, it accounts for $51.45 \%$ of the enrolment ratio in 1916.

In addition, the effect of the density of the local gentry remains positive and significant, after interacting with the tenure as magistrate. Moreover, if we calculate the coefficient for such density, the result is $0.058-0.029 * 1.03=0.028$. This is an encouraging result, which is quite consistent with those in Table 4.15.

The interaction term has a negative coefficient, which means that tenure as magistrate has a mitigating effect on the role of the gentry. It appears that the local gentry had a smaller impact on promoting primary schooling in counties with a relatively higher level of political stability. This negative interaction effect echoes historical narratives, whereby local gentry tended to assume local power to administer the provision of public goods in regions where formal governance was on the verge of collapse. The nature of the mitigating effect of the length of magistrate tenure is not trivial. Our calculations show that, evaluated by the mean, each extra year that a magistrate served in office mitigated the effect of quota density on primary enrolment ratio by $37.6 \%(0.029 * 1.22 / 0.094)$. In a nutshell, better administrative/ political stability brought better mass schooling, and the role of gentry was enlarged in counties with a more frequent turnover of magistrates.

\subsection{Economic outcomes and schooling development}

Apart from adding the role of the local gentry, this section seeks to provide some quantitative clues to the ambiguous relationship between educational development and economic prosperity. 
We include all the control variables $X_{i}^{\prime}$ and their interactions with time dummies in Table 4.17. With all the above combinations, the effect of the local gentry remains positive and significant; while the interaction effects with economic factors have quite diverse results.

First, population density has a negative association with primary schooling outcomes; this negative impact increased over time. It is an unexpected result; if we interpret population density as a proxy for commercialisation and urbanisation levels: it implies that a higher level of urbanisation did not bring any positive effect on mass education; instead, rural and remote regions may have performed better as regards primary schooling. Potential agricultural output measured by soil suitability for rice and wheat cultivation presents similar positive correlations with primary schooling. These two results suggest that in terms of primary education rich agricultural regions rose first.

This conjecture can further confirm the finding that the land tax quota in the late Qing period had its own positive influence on primary education. Land taxes had long been the chief tax revenue for the Chinese state, suggesting that the land tax quota in the late Qing was a good proxy for fiscal capacity, but should also correlate with the economic weight of agriculture in each region. Land taxes at first show no significant effects on schooling development in 1907, but this changed under the new education system for the latter two benchmark years.

Similar advantages in schooling outcomes in rural and economic backward areas have been observed in early $19^{\text {th }}$ century Meiji Japan and the USA, but the underlying reasons are likely to have been quite different in the Chinese context. The main revenue sources for the county budgets were surtaxes on land tax, while the lucrative Likin - a tax levied as an internal tariff and also on shops - was in the grip of the provincial treasury. The main funding body of primary education was the county government, which had no authority to lay hands on the Likin. It meant that highly commercialised regions could contribute to provincial treasuries, but not to county budgets; on the contrary, regions with a prosperous agriculture sector enabled county governments to mobilise more potential tax revenues for primary education. 
Table 4.19: Economic characteristics and primary enrolment ratios

\begin{tabular}{|c|c|c|c|c|c|c|}
\hline & & & Primary enr & Iment ratio & & \\
\hline & (1) & (2) & (3) & (4) & (5) & (6) \\
\hline Local gentry & $\begin{array}{c}0.00081 \\
(0.0002)^{* * *}\end{array}$ & $\begin{array}{c}0.00068 \\
(0.0002)^{* * * *}\end{array}$ & $\begin{array}{c}0.00082 \\
(0.0002)^{* * *}\end{array}$ & $\begin{array}{c}0.00084 \\
(0.0002)^{* * *}\end{array}$ & $\begin{array}{c}0.0011 \\
(0.0002)^{* * *}\end{array}$ & $\begin{array}{c}0.0013 \\
(0.00177)^{* * *}\end{array}$ \\
\hline Population density & $\begin{array}{c}-0.0033 \\
(0.001)^{* * *}\end{array}$ & & & & & \\
\hline Pop_density*Year1916 & $\begin{array}{l}0.00058 \\
(0.0009)\end{array}$ & & & & & \\
\hline Pop_density*Year1933 & $\begin{array}{c}-0.0009 \\
(0.00002)^{* * *}\end{array}$ & & & & & \\
\hline Soil suitability for rice & & $\begin{array}{c}0.0061 \\
(0.0019)^{* * *}\end{array}$ & & & & \\
\hline Rice *Year1916 & & $\begin{array}{c}-0.0054 \\
(0.002)^{* * *}\end{array}$ & & & & \\
\hline Rice *Year1930 & & $\begin{array}{l}-0.012 \\
(0.007)^{*}\end{array}$ & & & & \\
\hline Treaty port & & & $\begin{array}{c}0.023 \\
(0.005)^{* * *}\end{array}$ & & & \\
\hline Treatyport * Year1916 & & & $\begin{array}{c}0.001 \\
(0.007)\end{array}$ & & & \\
\hline Treatyport * Year1933 & & & $\begin{array}{c}-0.039 \\
(0.016)^{* * *}\end{array}$ & & & \\
\hline Distance to telegraph & & & & $\begin{array}{c}-0.0157 \\
(0.0045)^{* * *}\end{array}$ & & \\
\hline Telegraph* Year 1916 & & & & $\begin{array}{l}-0.005 \\
(0.007)\end{array}$ & & \\
\hline Telegraph* Year 1930 & & & & $\begin{array}{c}0.057 \\
(0.018)^{* * *}\end{array}$ & & \\
\hline Modern Industry & & & & & $\begin{array}{c}-0.01 \\
(0.005)^{*}\end{array}$ & \\
\hline Modern * Year 1916 & & & & & $\begin{array}{c}0.24 \\
(0.008)\end{array}$ & \\
\hline Modern * Year 1930 & & & & & $\begin{array}{c}0.037 \\
(0.021)^{*}\end{array}$ & \\
\hline Landtax quota in Qing & & & & & & $\begin{array}{c}0.00003 \\
(0.00018)\end{array}$ \\
\hline Landtax * Year 1916 & & & & & & $\begin{array}{c}0.00096 \\
(0.00016)^{* * *}\end{array}$ \\
\hline Landtax * Year 1933 & & & & & & $\begin{array}{c}0.0018 \\
(0.00046)^{* * *}\end{array}$ \\
\hline Time dummies & YES & YES & YES & YES & YES & YES \\
\hline Other controls & YES & YES & YES & YES & YES & YES \\
\hline Province FE & YES & YES & YES & YES & YES & YES \\
\hline Observations & 2701 & 2701 & 2701 & 2701 & 2701 & 2701 \\
\hline R-squared & 0.53 & 0.54 & 0.53 & 0.53 & 0.53 & 0.55 \\
\hline
\end{tabular}

*Note:

(i). In this table, the numbers of local gentry are based on the shenyuan quota number in the late Qing period

(ii). All the standard errors clustered at county level are shown in parentheses.

* significant at $10 \%$; * significant at $5 \%$; *** significant at $1 \%$. 
The effect of the penetration of Western ideas on education development is explored through a series of indicators. First, regions with treaty port status tend to have much better primary schooling, but over time the advantages of being a treaty port declined. This implies that exposure to Western ideas and information was more important for the residents' acceptance of modern schooling during the early phase of development than later. Consistent with the results for the treaty ports, we find that greater distance to the nearest telegraph station for a given county with less exposure to the outside world meant less primary education. The importance of this variable also declined through time.

For Christian activities, another proxy for the penetration of Western ideas, when it is measured by the ratio of enrolment in missionary primary schools, it shows a significant and positive effect on primary schooling expansion; while the number of communicants per 10,000 people has no statistical impact on primary schooling. This pattern indicates that Christianity mattered mainly through its 'learning effect', consistent with Kung and Bai's recent study (Kung \& Bai, Forthcoming).

Geographical controls show some interesting results; for instance, distance from the regional political centre, say, a prefectural seat, hindered the development of primary education.

In sum, owing to the crudeness of the demand-side control variables, it is difficult to generalise any conclusive claims, but several points from the above results are worth stressing. First, the influence of economic prosperity on the rise of primary schooling changed over time. In the early stages, it seems that the factors which affected people's acceptance - for instance, exposure to Western ideas and openness - played a more vital role. In contrast, when people began to adapt to the idea of modern education, the county's economic performance, in particular the strength of agriculture and fiscal capacity, mattered more. Agricultural regions did not hold any disadvantages in terms of primary schooling development; on the contrary, the rich, stable and agrarian counties were the front runners in terms of the expansion of education. 


\subsection{Alternative influencing mechanisms of the gentry: scholar culture?}

In previous sections, a causal link was established between the quotas (of lower degree holders) in the Qing dynasty, and primary schooling development through the early $20^{\text {th }}$ century. To interpret the gentry's effect, our argument is based on two factors: first, their long-standing public obligation to provide public goods, and second their private interests; the latter hinged on their view of the primary education sector as their potential job market. Therefore, it was the object of the local gentry to deliberately promote and support the expansion of primary schooling across China, when local governments had no capacity or incentive to do so. In summary, when the formal administrative capacity collapsed, they as a social elite group assumed power and provided informal rules to enforce social policies; for instance, the provision of public education. Second, the private interests of the local gentry, both politically and economically, were in line with their control of the primary education sector.

However, there are many other possible mechanisms through which the legacy of traditional education could have affected modern schooling, the most likely channel being clear from a cultural perspective. There are places where people always perform better in education, no matter what kind of education, Western or Confucian. Global evidence shows that education performance tends to have a high degree of persistence across regions and over time. The inertia of educational attainment may be genetic, but is more likely to be deeply rooted in culture. In the context of China, through the long history of the civil service exam, counties with a higher quota density may have generated a higher cultural respect for the value of education among its people, which facilitated the successful spread of modern education. ${ }^{225}$ To test whether this alternative explanation is valid, we perform two tests on the effect of the 'scholar culture' on modern schooling expansion.

To begin with, a logistic regression was run to test the effect of quota density on the higher level of schooling; namely, secondary education. If the channel of influence of

\footnotetext{
${ }^{225}$ For instance, Wu county (吴县) in the Suzhou prefecture of Jiangsu Province, was famous for its literary ethos; it was the place that bred the highest number of Zhuangyuan (scholars who scored highest at the highest level of the civil service examination) in Chinese history. Persistently, in our own day, Wu county has been the home town of a large number of leading scholars, poets, and social scientists, showing the high legacy of its highly scholarly culture.
} 
the gentry is a cultural legacy, the effect should not be limited to primary education alone. The estimates show that the coefficients are not significant across the three benchmark years. Results in Table 4.18 show that the number of local gentry specifically contributed to the expansion of primary education, but showed no regard for higher levels of schooling. As discussed earlier, since secondary schooling was dominated by people with a modern education background, and tertiary schooling was mainly a job market for people who had studied abroad the local gentry had limited incentive to support secondary schools.

As a further measurement check, we constructed an indicator to proxy the literary ethos or what we might refer to as the 'scholar culture'. As emphasised, regional variation in the quota numbers of Shengyuan was not determined by the educational performance or the scholar culture under the traditional education system, since it was fixed by the Qing court. However, the number of Jinshi (the number of top scholars who passed the palace exam) could have reflected the education performance across counties within one province, because the quota for Jinshi were allocated at the provincial level (C. Chang, 1955, pp. 122-123). Accordingly, we constructed a ratio that reflects 'scholar culture', which is very similar to a graduation rate.

$$
\frac{\text { Jinshi }_{i}}{\text { Quota of Shengyuan }}
$$

Given the same number of quotas of shengyuan, the number of Jinshi that could be cultivated at the county level reflects the education quality in a given county. It is reasonable to assume that in regions where education was perceived as more honoured and culturally encouraged, its inhabitants tended to have a higher incentives to study diligently, thus generating better educational performance.

We use this ratio to measure the cultural valuation of education in a given county. Adding it to the baseline specification, the results in Table 4.20 show no significant effect on the primary enrolment ratio or primary school density. Both the tests used confirm that regions where the residents used to be 'good at' traditional education were not necessarily the ones where modern primary schooling was successfully diffused. Therefore, the legacy of traditional education cannot present its role in promoting modern schooling simply as a matter of cultural persistence. 
Table 4.20: Alternative influencing mechanism

\begin{tabular}{lccc|cccc}
\hline & \multicolumn{3}{c|}{ Logit (secondary) } & \multicolumn{4}{c}{ Primary Enrolment Ratio } \\
\hline & 1907 & 1916 & 1933 & & 1907 & 1916 & 1933 \\
\hline \multirow{2}{*}{ Local gentry } & 0.42 & -0.25 & -0.18 & Scholar & 0.00029 & -0.00089 & -0.00053 \\
& $(0.32)$ & $(0.19)$ & $(0.21)$ & Culture & $(0.0003)$ & $(0.003)$ & $(0.0008)$ \\
\hline Controls & Yes & Yes & Yes & & Yes & Yes & Yes \\
FE province & Yes & Yes & Yes & & Yes & Yes & Yes \\
Observations & 904 & 1066 & 599 & & 904 & 1066 & 599 \\
\hline \hline
\end{tabular}

\section{Notes:}

(i). In this table, the numbers of local gentry are based on the shenyuan quota density( normalised by 1907 county population). Scholar culture is measured by jinshi/shengyuan quota

(ii). Control variables include: potential soil quality for rice cultivation, late Qing land tax quota, modern industry location dummy, treaty port dummy, density of Christians over 10000 people, distance to nearest telegraph station, distance to prefectural seat, distance to provincial capital, dummy for Yangtze river, dummy for coastal area.

(iii). All the standard errors clustered at county level are shown in in parentheses.

* significant at $10 \%$;* significant at $5 \%$;** significant at $1 \%$.

Both the tests used confirm that regions where residents had previously thrived in traditional education were not necessarily the ones where modern primary schooling was successfully diffused. Thereby, the legacy of traditional education does not influence modern schooling simply and solely as a matter of cultural persistence.

\section{Concluding Remarks}

Using newly assembled data from archival sources, this chapter unveils the driving forces of mass schooling at the local level. Inspired by a rigorous approach to identifying causal effects in economics, this chapter adopts an array of empirical strategies to pin down the determinants of the mass expansion of schooling.

The dominant finding of this chapter lies in the critical role of one elite group - the gentry - on the expansion of modern education. Early $20^{\text {th }}$ century China was a place of political turmoil where formal political institutions failed in many public responsibilities, including schooling provision; local elite groups therefore seized the power to replace them and became vital decision makers. Given that gentry status was obtained via the traditional education system, the importance of the gentry connects the legacy of traditional education with modern mass schooling. Regions that had 
historically advocated education would naturally possess a larger reserve of gentry members, which led to better performance in modern education when it was first introduced; more importantly, the mechanisms for the gentry's effect were mainly through the gentry's public and private incentives, rather than the cultural legacy of traditional education.

These findings present broad implications beyond the Chinese context. In nondemocratic societies or failing nations, informal institutions can step in and provide benevolent governance in the absence of formal institutions. Equally noteworthy, the finding that one social elite group contributed substantially to the rise of public mass schooling is made in sharp contrast to the early stages of educational development in Europe, England in particular, where the landholding elites were seen as the main interest group blocking the public provision of education to the populace.

In addition, the roving bandit story is applicable in the Chinese case. Regions with higher political stability generating better accountability emerged. Furthermore, the negative interaction term between a magistrate's tenure and the gentry's strength also partially confirms our conjecture that the local gentry tended to wield a stronger influence in regions with less stable formal political control (inferred from the more frequent turnover of county magistrates).

Finally, this chapter also provides some general clues to the ambiguous relationship between educational development and economic factors. First, one noteworthy finding is that modern schooling provision was not necessarily better in urban and industrial cities; on the contrary, a close negative relationship between population density and modern schooling development is observed. Many factors closely associated with agricultural production pointed to the possibility that regions with a stronger agricultural sector enjoyed better modern primary education, partly because the surtaxes on agricultural production were the only tax revenue sources that county governments (the decision-making bodies of primary education) could control. In addition, historical arguments related to the importance of exposure to new, possibly foreign ideas, are confirmed by our results. Regions with more international trade, missionary activities, or better modern communication technologies showed notable advantages in the initial stages of educational progress. 


\section{Conclusion}

This thesis is motivated by the greatest educational movement in Chinese history the transformation from traditional Confucius teaching to modern national education at the dawn of the $20^{\text {th }}$ century, which altered the trajectory of Chinese development in subsequent decades. The empirical studies of Chinese educational development have concentrated heavily on the period after the founding of the People's Republic of China in 1949, leaving the origin and the early stages of China's educational progress remarkably under-examined.

So far our understanding of educational development through its early stages has remained ambiguous on a number of questions: How much did human capital rise after the introduction of the modern education system? Did education progress evenly across China? What socio-economic factors can explain the diffusion of the modern form of schooling? With new data based on extensive archival material and historical government reports, this study is able to provide many quantitative dimensions of the rise of schooling in China through the first half of the $20^{\text {th }}$ century for the very first time; and also to unravel the explanatory factors in the rise of modern schooling. This thesis sets out to answer these questions by surveying the evolution of the education system from the late $19^{\text {th }}$ century onward, measuring its progress and the succeeding rise of human capital, and finally investigating what factors determined its diffusion.

In this conclusion chapter, the empirical findings of this thesis are summarized, followed by a view of the implications that could be drawn from them and, at the end, a brief set of suggestions for future research along the same lines.

\section{Main findings}

$\mathrm{Al}$ through the literature on education, the formation of a national education system is widely believed to be promoted only by a strong state. However, the historical course of China between the late Qing and the Republican era presents us with an exceptionally interesting scenario. As a national salvation, the fact is that a radical national education system was initiated by a withering state and largely supported by 
informal institutions. The formation of the modern education model occurred in China when the process of state formation was at its most intensive.

\section{Quantitative dimensions of the rise of schooling}

First and foremost, the results of this thesis map the quantitative dimensions of the education development in China through the first half of the $20^{\text {th }}$ century. Between 1900 and 1949, formal schooling modelled upon Western countries and generously largely supported by public contributions, expanded at unprecedented speed.

As measured by the gross enrolment ratio, the primary enrolment ratio soared from zero to 27 percent before 1937; even though secondary and tertiary schooling experienced less impressive progress, given the absolutely primary importance of primary schooling at this stage, it is safe to claim that China's population has borne the marks of its phenomenal formal educational expansion ever since. To put such achievement into perspective, there was a notable catch-up with its developing counterparts, such as India and Brazil, from 1900 to 1950. The prominent progress in education was not only in terms of quantity, but also in quality. For the very first time, young talents were given the chance to access a broader spectrum of knowledge and explosive new ideological trends.

Nonetheless, the educational stock plots a scenario that is slightly different. In terms of human capital stock, China continued to lag badly behind other major developing countries, and the gap endured, if not enlarged, until the 1960s. The average years of schooling for the workforce (people 15-64 years old) stood at barely 0.5 in 1920 and had risen only slightly to 1.31 in 1950 , when only formal education is included. Looking at the average years of schooling by birth cohort at age 30, the results present a very similar trend: that people born before 1924 (most of whom presumably received education during the first half of the $20^{\text {th }}$ century) enjoyed only a modest increase in educational stock, from zero to 1.65 years. On the basis of different data, this study argues that the delayed growth in educational attainment may be attributed to the fact that a large proportion of Chinese who received education in informal traditional schools (Sishu) failed to be counted in most of the calculations when we measured the average years of schooling for Chinese people at the time. Apart from the aggregate trend, the human capital stock series also present the changing 
trajectory of the gender gap, as well as the urban-rural inequality for the birth cohorts of the $20^{\text {th }}$ century. Apparently, the difference of educational attainment between Chinese males and females narrowed considerably over the last century, in particular for people born after the 1930s; unfortunately, a similar convergence was not witnessed in the urban-rural disparities.

\section{Determinants of mass education expansion}

Apart from the aggregate result, given the sheer size of China and the notable regional disparities in economic prosperity, this thesis also presents the geographically uneven rise of education across regions. Such diverse educational progress offers us an empirical ground for our second finding, which concerns the driving forces in the rise of modern schooling, primary education in particular. We claim that mass primary schooling regarded as a public good, was largely an outcome of politico-economic dynamics but not simply of economic prosperity.

The dominant finding of this thesis lies in the critical role of one elite group - the gentry - in securing the provision of modern education in China throughout this period. Due to their seizing power at the local level, the local gentry consistently encouraged the provision of modern primary education within their localities, not only because of their sense of moral obligation, but also to further their own private interests in financial gain and preserving the legitimacy of their status in their local communities as educated elites. Moreover, the story of the 'roving bandit' is also applicable to the Chines context, in that it exemplifies the importance of administrative/political stability; more importantly, this finding also suggests that the gentry's positive effect on schooling was very much more notable in regions suffering higher levels of political instability. Finally, even though no conclusive arguments can be drawn about the way in which economic development influences education provision, the research makes several noteworthy findings. For one, it is abundantly clear that rich rural regions performed perceptibly better in primary education provision, partly because land tax surtaxes had been the main revenue source that the county government could lay its hands on. Moreover, the factors that may contribute to people's acceptance and tolerance of a new education system, for instance, exposure to the influence of the West and openness to modern communication, seem 
to play much more critical roles in its initial stages, although the positive effect of these fades away gradually.

\section{Contributions and implications}

To begin with, unlike existing empirical studies on China covering the same period, this study compiles a county-level dataset. Substantial historical narratives indicate that, due to China's sheer size and distinctive diverse economic and social conditions, using prefectural or even provincial level data to explain socio-economic variations in China loses much of the essential dispersion and many important underlying patterns.

In addition, this thesis also contributes two major advances to the literature on education development in China. First, its analysis provides considerable quantitatively detailed data on the rise of schooling in China, which allow a more comprehensive understanding of its progress, and allow us to make international comparisons with China regarding education. In addition, this thesis also tackles the important question of what determined the rise of modern education. The findings for an explanation of the driving forces of this rise are exceptionally important, not only because they enrich our understanding of what drove up the education, but also because it connects the historical legacy of traditional education with the rise of modern schooling.

However, this study is not relevant to Chinese educational progress alone; it also provides empirical evidence on the notable importance of the gentry in local governance. Despite the large literature claiming the vital role of the local gentry in Chinese history, there are very few rigorous studies that examine its direct impact on spheres of governance, and even fewer mentioning how the gentry's role changed in the dynamic of the radical social transformation at the dawn of the $20^{\text {th }}$ century, when the institution that had granted legitimacy to the gentry as an elite was removed.

Moreover, this thesis has broader general implications that go beyond the Chinese context. First, it sheds light on the determinants of education in societies equipped with different political institutions and a very backward economy, in the eyes of the developed world. The literature targeting the OECE countries emphasises the role of 
decentralisation and local democracy as main engines for schooling expansion; this study adds to these the part played by local administrative stability and the benign nature of social elites in explaining schooling outcomes in societies where a decentralized structure meets local authoritarian politics. Second, this study makes a sharp contrast with the literature that argues that social elites always formed the main interest groups that sets out to block public schooling to the masses (as it did in many European countries). Finally, because mass education can be seen as one of the most widely influential public goods, this study may apply to the much broader question of understanding the provision of public goods in the developing word. Our main finding - the beneficent role of a certain elite group - adds evidence to a recently growing body of literature stressing the importance of informal institutions enforced by social groups in providing public goods in non-democratic societies.

\section{Future research}

Looking ahead, this thesis leaves many questions unanswered. One particular research puzzle I would like to purse is to examine why regions with higher primary enrolment ratios were not necessarily those with better performance in terms of secondary schooling. The general pattern of educational development around the globe follows the natural order: primary schooling rises first, then secondary schooling, and finally tertiary education. However, in societies where a certain set-up of political economy allows elites to capture public resources, the limited resources for education tend to be funnelled towards secondary and tertiary schooling catering to the middle or upper class, even when primary education has not yet permeated everywhere a mong the masses (Chaudhary, 2009; Chaudhary et al., 2012). This biased progress in education would harm the effective allocation of educational resources, so what kind of provincial political economy shaped the mis-allocation of insufficient educational resources in China?

In addition, following the same lines as this thesis, another research project could be further developed. There is an increasing literature arguing the persistence of social institutions and its effect on long-term economic developments. China's educational development would be a good testing ground to examine whether the inertia hinging on social institutions was cut away by changes in the political system. In my $\mathrm{PhD}$ 
thesis, as mentioned, we find that places which outperformed in Confucius teaching were also the ones at an advantage when it came to developing modern schooling. Naturally, the next step would be to test whether this regional pattern held good through the communist era. 


\section{Bibliography}

A'Hearn, B., Baten, J., \& Crayen, D. (2009). Quantifying Quantitative Literacy: AgeHeaping and the History of Human Capital. Journal of Economic History, 69(3), 783-808.

Abe, H. (1987). Borrowing from Japan: China's First Modern Educational System. In R. Hayhoe \& M. Bastid (Eds.), China's Education and the Industrializaed World: Ontario Institute for Studies in Education.

Acemoglu, D., Johnson, S., \& Robinson, J. (2002). Reversal of Fortune: Geography and Institutions in the Making of the Modern World Income Distribution. Quarterly Journal of Economics, 117, 1231-1294.

Bai, Y. (2014). Farewell to Confucianism: The Modernizing Effect of Dismantling China's Imperial Examination System. Hong Kong University of Science and Technology

Barro, R., \& Lee, J.-W. (1993). International Comparisons of Educational Attainment. Journal of Monetary Economics, 32(4), 363-394.

Barro, R., \& Lee, J.-W. (1996). International Measures of Schooling Years and Schooling Quality. American Economic Review, 86, 218-223.

Barro, R., \& Lee, J.-W. (2001). International Data on Educational Attainment: Updates and Implications Oxford Economic Papers.

Baten, J., Ma, D., Morgan, S., \& Wang, Q. (2010). Evolution of Living Standards and Human Capital in China in the 18-20th Centuries: Evidences from Real Wages, Age-Heaping, and Anthropometrics. Explorations in Economic History, 47(3), 347-359.

Becker, G. (1964). Human Capital: A Theoretical and Empirical Analysis, with Special Reference to Education. Chicago: Unviersity of Chicago Press.

Behman, J., \& Schneider, R. (1994). An International Perspective on Schooling Investments in the Last Quarter Century in Some Fast-Growing East and Southeast Asian Countries. Asian Development Review of Income and Wealth.

Beltran Tapia, F. J. (2013). Enclosing literacy? Common lands and human capital in Spain, 1860-1930. Journal of Institutional Economics, 9(04), 491-515. doi: 10.1017/s1744137413000209

Benavot, A., \& Riddle, P. (1988). The Expansion of Primary Education, 1870-1940: Trends and Issues. Sociology of Education, 61(3), 191-210.

Bergère, M.-C. (1986). Chapter 12: The Chinese bourgeoisie, 1911-37 In J. K.

Fairbank \& A. Feuerwerker (Eds.), The Cambridge History of China (Vol. 12): Cambridge University Press.

Besley, T., \& Case, A. (1995). Does Electoral Accountability Affect Economic Policy Choices? Evidence from Gubernatorial Term Limits. The Quarterly Journal of Economics, 110(3), 769-798.

Billingsley, P. (1988). Bandits in Republican China: Standford University Press.

Black, S. E., \& Sokoloff, K. L. (2006). Long-Term Trends in Schooling: The Rise and Decline (?) of Public Education in the United States. In E. A. Hanushek, S. Machin, \& L. Woessmann (Eds.), Handbook of the Economics of Education (Vol. 1): Elsevier Science.

Bol, P. K., \& Ge, J. (2007). China Historical GIS. In H. Y.-c. Library (Ed.).

Borthwick, S. (1983). Education and Social Change in China: the Beginning of the Modern Era. Hoover Institution Press. 
Bowles, S., \& Gintis, H. (1976). Schooling in Capitalist America: Educational Reform and the Contradictions of Economic Life: Routledge.

Brandt, L., Ma, D., \& Rawski, T. (2014). From Divergence to Convergence: Reevaluating the History Behind China's Economic Boom. Journal of Economic Literature, 52(1), 45-123.

Broadberry, S. (2004). Human capital and skills. In R. Floud \& P. Johnson (Eds.), The Cambridge Economic History of Modern Britain (Vol. 2, pp. 56-73): Cambridge University Press

Buck, J. L. (1937). Land Utilization in China. Nanking: University of Nanking Press.

Campante, F. R., \& Chor, D. (2012). Schooling, Political Participation, and the Economy. The Review of Economic and Statistics, 94(4), 841-859.

Cao, S. (2000). Zhongguo Renkou Shi: Qing Shiqi (Population History of China: Qing period). Shanghai Fudan Unversity Press.

Cappeli, G. (2014). One size didn't fit all: the role of electoral franchise and fiscal capacity in the rise of schooling for all across Italy's provinces, c. 1871-1911. European University Institute

Carolyn, T. (2001). Child Labor during the British Industrial Revolution. EH.Net Encyclopedia.

Castelló-Climent, A. (2008). On the Distribution of Education and Democracy. Journal of Development Economics, 87, 179-190.

Chang, C. (1955). The Chinese Gentry: Studies on Their Role in Nineteenth Century Chinese Society. Seattle: University of Washington Press.

Chang, C. (1962). The Income of the Chinese Gentry. Seattle: University of Washington Press.

Chang, J. (1955). Industrial Development in Pre-Communist China: Stanford University Press.

Chang, Y. (1989). Private Industries in the Late Ch'ing and the Early Republic of China, 1860-1916. Bulletin of the Insitute of Modern History, Academia Sinica, $18,315-561$.

Chaudhary, L. (2009). Determinants of primary schooling in British India. The Journal of Economic History, 69(1).

Chaudhary, L., Musacchio, A., Nafziger, S., \& Yan, S. (2012). Big BRICs, Weak foundations: the beginning of public elementray education in Brazil, Russia, India, and China. Explorations in Economic History, 49(2).

Chauncey, H. R. (1992). Schoolhouse Politicians: locality and state during the Chinese Republic. Hawaii: University of Hawaii Press.

Chen, J. (1968). Defining Chinese Warlords and Their Factions. Bulletion of the schools of Oriental and African Studies, 31(03), 563-600.

Chen, T. H.-e. (1974). The Maoist educational revolution

Praeger Publishers.

Cheng, S. (1919). Modern China: A political Study: Oxford Unviersity Press.

Cheng, S.-G. ( 1919.). Modern China: a Political Study. Oxford: The Clarendon Press.

Chi, C.-T. (1936). Key Economic Areas in Chinese History: as Revealed in the Developmehnt of Public Works for Water-Control. London: George Allen\&Unwin LTD.

Chi, H. (1976). Warlord Politics in China, 1916-1928. California: Stanford Unviersity Press.

Chi, H.-S. (1976). Warlord Politics in China, 1916-1928: Stanford University Press.

Chien, T.-S. (1950). The Government and Politics of China Havard University Press. 
Clark, G., \& Feenstra, R. (2001). Technology in the Great Divergence. NBER Working Paper No.8596.

Cohen, D., \& Soto, M. (2007). Growth and Human Capital: Good Data, Good Results. Journal of Economic Growth, 12, 21-76.

Collins, K. (2003). The Political Role of Clans in Central Asia. Comparative Politics, $35(2), 171-190$.

Cressy, D. (2006). Literacy and the Social Order: Reading and Writing in Tudor and Stuart England: Cambridge University Press.

. Da Qing youzheng gongshu beiyong yutu (China postal working map) (1907). Shanghai: Statistical department of the inspectorate general of customs

Deng, K. G. (2011). China's political economy in modern times : changes and economic consequences, 1800-2000: Routledge

Deng, P. (1997). Private Education in Modern China: Praeger Publishers.

Deng, Z., \& Treiman, D. J. (1997). The Impact of the Cultural Revolution on Trends in Educational Attainment in the People's Republic of China. American Journal of Sociology 103, 391-428.

Dennerline, J. (1975). Fiscal reform and local control: the gentry-bureaucratic alliance survivies the conquest. In F. Wakeman \& C. Grant (Eds.), Conflict and Control in late Imperial China. Los Angeles University of California Press.

Dewey, J. (1916). Democracy and Education: An Introduction of the Philosophy of Education. New York: Macmillan.

Dobson, W. (Ed.). (2013). Human Capital Formation and Economic Growth in Asia and the Pacific: Routledge

Du, Z., \& Yang, S. (1934). Jiangzhe Liangsheng Gexian Difangjiaoyu Jiangfei de diaochahebijiao (Surveys on educational expenditure and revenues of Jiangsu and Zhejiang provinces). Xiamen: Xiamen University Press.

Duara, P. (1988). Culture, Power, and the State: Rural North China, 1900-1942. California: Stanford University Press.

Easterlin, R. A. (1981). Why Isn't the Whole World Developed? The Journal of Economic History, 41(1), 1-19.

Eastman, L. E., Fairbank, J. K., \& Feuerwerker, A. (1986). Nationalist China during the Nanking decade 1927-1937. 116-167. doi: $10.1017 /$ chol 9780521243384.004

Eckstein, A., Chao, K., \& Chang, J. (1974). The Economic Development of Manchuria:The Rise of a Frontier Economy. The Journal of Economic History, 34(1), 238-264.

. The education finance of Yunnan province (1933). Education Department of Yunnan province.

Elman, B. (2000). A Cultural History of Civil Examinations in Late Imperial China: University of California Press.

Elman, B. A. (2013). Civl Examinations and Meritocracy in Late Imperial China: Havard University Press.

Engerman, S. L., Mariscal, E., \& Sokoloff, K. L. (2009). The Evolution of Schooling in the Americas, 1800-1925. In F. D. Lewis, D. Elits, \& K. L. Sololoff (Eds.), Human Capital and Institutions: The Long-Run View: Cambridge University Press.

Esherick, J. W. (1990). Chinese local elites and patterns of dominance. Los Angeles: University of California Press.

Fairbank, J. K. (1978). The old order In J. K. Fairbank (Ed.), The Cambridge History of China: Late Ch'ing 1800-1911 (Vol. 10). 
Feuerwerker, A. (1986). Economic trends: 1912-49. In J. K. Fairbank \& D. Twitchett (Eds.), The Cambridge History of China: Cambridge University Press.

Fiske, E. B. (1996). Decentralization of Education :Politics and Consensus. Washington, D.C.: The Word Bank.

Freire, P. (1976). Education, the practice of freedom: London Writers and Readers Publishing Cooperative.

Frenandez, R., \& Rogerson, R. (2001). The Determinants of Public Education Expenditures: Longer-Run Evidence from the States. Journal of Education Finance, 27(1), 567-583.

Fukao, K., Ma, D., \& Yuan, T. (2007). Real GDP in Pre-War East Asia: a 1934-36 Benchmark Purchasing Power Parity Comparison with the U.S. Review of Income and Wealth, 53(3).

Gallego, F. A. (2010). Historical origins of schooling: The role of democracy and political dencentralization. The Review of Economic and Statistics, 92(2).

Gamble, S. D. (1954). Ting Hsien, A North China Rural Community. New York: Institute of Pacific Relation.

Gamble, S. D., \& Burgess, H. S. (1921). Peking: A Social Survey: George M. Doran Company.

Gillin, D. G. (1960). Portrait of a Warlord: Yen Hsi-shan in Shansi Province, 19111930. The Journal of Asian Studies 19(30), 289-306.

Go, S., \& Park, K.-J. (2012). The elite-biased growth of elementary schooling in colonial Koera. Modern and comparative economic history seminar. Economic History. London School of Economics and Political Science. London.

Godo, Y. (2001). Estimation of Average Years of Schooling by Levels of Education for Japan and the United States, 1890-1990. Meji Gakuin University.

Godo, Y., \& Hayami, Y. (1999). Accumulation of Education in Modern Economic Growth: A Comparison of Japan with the United States. Asian Development Bank.

Goldin, C. (1998). America's graduation from high schoo: the evolution and spread of secondary schooling in the twentieth century. The Journal of Economic History, 58(2).

Goldin, C. (2015). Human Capital. In C. Diebolt \& M. Haupert (Eds.), Handbook of Cliometrics: Springer-Verlag

Goldin, C., \& Katz, L. F. (2008). The Race Between Education and Technology: Harvard University Press.

Goldin, C., \& Katz, L. F. (2009). Why the United States Led in Education: Lessons from Secondary School Expansion, 1910 to 1940. In D. Eltis, F. D. Lewis, \& K. L. Sokoloff (Eds.), Human Capital and Institutions: A Long-Run View: Cambridge University Press.

Goldin, C., \& Katz, L. F. (2011). Mass Secondary Schooling and the State: The Role of State Compulsion in the High School Movement. In C. D \& L. N (Eds.), Understanding Long Run Economic Growth: Cambridge University Press.

Goldin, C., \& Sokoloff, K. (1982). Women, Children, and Industrialization in the Early Republic: Evidence from the Manufacturing Censuses. The Journal of Economic History 42(4), 741-774.

Gray, W. S. (1957). World Illteracy at Mid-Century, a Statistical Study: UNESCO.

Green, A. (1990). Education and State Formation: The Rise of Education Systems in England,France, and the U.S.A. New York: St. Martin's Press. 
Griffin, Keith, \& Renwei, Z. (1988). Chinese Household Income Project. In S. S. B. o. China (Ed.): Ann Arbor, MI: Inter-university Consortium for Political and Social Research

Gunde, R. (1976). Land Tax and Social Change in Sichuan, 1925-1935. Modern China, 2(1), 23-48

Hanushek, E. A., \& Woessmann, L. (2011). The Economics of International Differences in Educational Achievement. In E. A. Hanushek, S. Machin, \& L. Woessmann (Eds.), Hanbook of the Economics of Education Volume 3: Elsevier Science

. Hebeisheng Gexian Putong Jiaoyu Gailan (The county-level reports for general edcuation in Hebei province). (1928).

Helmke, G., \& Levitsky, S. (2004). Informal Institutions and Comparative Politics: A Research Agenda. Perspectives on Politics, 2(4), 725-740.

. Henan jiaoyu yianjian (The Education Yearbook of Henan province). (1930).

Ho, P.-t. (1962). The ladder of success in Imperial China: aspects of social mobility, 1368-1911. New York: Columbia University Press.

Hou, Y. (2001). Zhongguo Renkou Shi: Minguo Shiqi (Population History of China: Republic of China period)

: Fudan University Press.

Hsiao, K.-C. (1960). Rural Chian: Imperial Control inf the Nineteenth Century. Seattle: University of Washington Press.

Hu, X. (2009). Qingmo Zhongguo Minzhong Sishu Jioxuelv de kaocha (A Study of Private Sishu Enrolment Ratios in the End of Ching Dynasty). Kyoto University Research Infomation Repository. Kyoto University. Kyoto.

Huff, T. E. (2003). The Rise of Early Modern Science: Islam, China and the West: Cambridge Unviersity Press.

. Hunan quansheng Jiaoyu Tongji (The education reports for Hunan province). (1931).

. Hunansheng Zuijin Geniandu Shengshixianqu Jiaoyu Jingfei Diaocha Tongji (The county-level reports on education finance of Hunan Province). (1933).

Ichiko, C. (1980). Political and institutional reform 1901-11 In J. K. Fairbank \& K.-C. Liu (Eds.), The Cambridge History of China (Vol. 11): Cambridge University Press Volume 11: Late Ch'ing, 1800-1911, Part 2.

Jia, R. (2014). The legacies of forced freedom: China's Treaty Ports. accepted by Review of Economic and Statistics. School of International Relations and Pacific Studies. University of California, San Diego.

Jiang, Q. (Ed.). (2007). Qingchao Jinshi Timinglu ( The full records of Jinshi in Qing dynasty): Zhonghua Book Company

. Jiangsu Jiaoyu Gailan (The education reports for Jiangsu province). (1933).

John R. Lott, J. (1999). Public Schooling, Indoctrination, and Totalitarianism. Journal of Political Economy, 107(s6), 127-157.

Jones, B. F. (2008). The Knowledge Trap: Human Capital and Development Reconsidered. NBER Working Paper.

Kaestle, C. (1976). Between the Scylla of Brutal Ignorance and the Charybdis of a Literary Education: Elite Attitude toward Mass Schooling in Elary Industrial England and America. In L. Stone (Ed.), Schooling and Society: Studies in the History of Education (pp. 177-191): Johns Hopkins University Press.

Keenan, B. C. (1994). Imperial China's Last Classical Academies: Social Change in the Lower Yangzi, 1864-1911: The Regents of the University of California. 
Krueger, A. B., \& Lindahl, M. (2001). Education for Growth: Why and for Whom? Journal of Economic Literature, 39(4), 1101-1136.

Kuhn, P., \& Jones, S. M. (1978). Dynastic Decline and the Roots of Rebellion. In J. K. Fairbank (Ed.), The Cambridge History of China, Late Ch'ing, 1800-1911 (Vol. 10, pp. 107-162): Cambridge University Press.

Kuhn, P. A. (1978). The Taiping Rebellion. In J. k. Fairbank (Ed.), The Cambridge History of China Volume 10: Late Ch'ing 1800-1911, Part 1 (Vol. 10, pp. 264-317): Camebridge University Press.

Kun, G. (1899). Qinding Da Qing Huidian Shili ( Imperiall Established Insitutes and Laws of the Great Qing Dynasty). Beijing Zhonghua Shu Ju.

Kung, J. K.-s., \& Bai, Y. (Forthcoming). Diffusing Knowledge While Spreading God's Message: Protestantism and Economic Prosperity in China, 18401920.“ (with Ying Bai). Accepted for publication Journal of European Economic Association

Kuo, P. W. (1913). The Effect of the Revolution upon the Educational System of China. The Journal of Race Development, 4(1), 72-85.

Kyriacou, G. A. (1991). Level and Growth Effects of Human Capital: A CrossCountry Study of the Convergence Hypothesis. Economic Research Reports New York University, C.V. STARR Center For Applied Economics.

Lam, T. (2011). A Passion for Facts: Social Surveys and the Consturction of the Chinese Nation-State, 1900-1949: University of California Press.

Lance, L. (2011). Nonproduction Benefits of Education: Crime, Health, and Good Citizenship. In E. A. Hanushek, S. Machin, \& L. Woessmann (Eds.), Handbook of the Economics of Education (Vol. 4): Elsevier Science

Landes, D. S. (2006). Why Europe and the West? Why Not China? Journal of Economic Literature, 48(2), 281-355.

Lange, F. (2006). The Social Vaule of Education and Human Capital. In E. A. Hanushek, S. Machin, \& L. Woessmann (Eds.), Handbook of the Economics of Education (Vol. 1): Elsevier Science.

Lary, D. (2007). China's Republic Cambridge University Press.

Lau, L. J., Jamison, D. T., \& Louat, F. F. (1991). Education and productivity in developing countries : an aggregate production function approach. Word Development Report. The World Bank.

Le, T. H., \& Meleisea, E. (2013). Decentralized Finance and Provision of Basic Education Asia-Pacific Education System Review Series (Vol. 4). Bangkok: United Nations, Educational, Scientific and Cultural Organization

Asia and Pacific Regional Bureau for Education.

Leeuwen, B. V. (2007). Human Capital and Economic Growth in India, Indonesia and Japan: A quantitative analysis, 1890-2000. (PhD), Utrecht University.

Li, C. S. (1922). Central and Local Finance in China: A study of the Fiscal Relations between the Central, the Provincial, and the Local Governments. New York: Columbia University Press.

Li, H. (1997). Minguo Jiaoyushi ( The History of Education through the Republic of China) Shanghai: Shanghai Education Press.

Li, H., \& Zhou, L. a. (2005). Political turnover and economic performance: the incentive role of personnel control in China. Journal of Public Economics, 89(9-10), 1743-1762.

Li, W., Xia, M., \& Huang, X. (2006). Chengshi (Laogong) Shenghuojuan, Minguo Shiqi Shehui Tiaocha Congbian ( Soical surveies on workers during Republican of China): Fujian Education Press. 
Li, Y. (2005). The Structure and Evolution of Chinese Social Stratification:

University Press of America.

Liao, Q. (1936). Biandongzhongde Zhongguo nongcun Jiaoyu --

Shandongwenshangxianjiaoyu yanjiu (Education in Changing China: a Study

of Wen County in Shandong Province). Shandong: Education Study Press.

Lin, J. Y. (1995). The Needham Puzzle: Why the Industrial Revolution Did Not

Orinigate in China. Economic Devlopment and Cultural Change, 43(2), 269292.

Lindert, P. (2004a). Growing Public: Social Spending and Economic Growth since the Eighteenth Century (Vol. 1): Cambridge University Press.

Lindert, P. (2004b). Growing Public: Social Spending and Economic Growth since the Eighteenth Century.

Lindert, P., \& Go, S. (2010). The unevern rise of Amiercan public schools to 1850. The Journal of Economic History, 70(1).

Liu, S. (1935). Zhongguo Tianfu Wenti (The study on land tax of China). China: Shangwu Yinshuguan.

Liu, T.-C., \& Yeh, K. C. (1965). The Economy of the Chinese Mainland: National Income and Economic Development, 1933-1959.: Princeton University Press.

Liu, T. C. (1946). China's National Income 1931-36: An Exploratory Study, . Washington DC: The Brookings Institution.

Lott, J. R. (1990a). An explanation for public provision of schooling the importance of indoctrination. Journal of Law and Economics 33(1), 199-231.

Lott, J. R. (1990b). An Explanation for Public Provision of Schooling; the Importance of Indoctrinaion. Journal of Law and Economics XXXIII, 199-232.

Lu, D. D. (1934). A History of Democratic Education in Modern China. Shanghai: The commercial Press.

Luween, B. V., \& Foldvari, P. (2008). Human Capital and Economic Growth in Asia 1890-2000: a time-series analysis. Asian Economic Journal, 22(3), 225-240.

Lv, X., \& Liu, M. (2013). Public goods with private benefits: understanding local governments' incentives in education provision in China. Paper presented at the Annual meeting of the Political Science Association, Chicago.

Ma, D. (2008). Economic growth in the lower Yangzi region of China in 1911 - 1937: a quantitative and historical analysis. The Journal of Economic History, 68(2), June.

Maddison, A. (2006). The World Economy: A Millennial Perspective. Washington D.C.: Organisation for Economic Co-operation and Development.

Marianne. (1985). The Structure of the Financial Institutions of the State in the Late Qing. In S. R.Schram (Ed.), The Scope of State Power in China: University of London School of Oriental and African Studies.

Mccord, E. A. (1993). The power of the gun: the emergence of modern Chinese Warlordism. Berkeley, California: University of California Press.

McDonald, A. W. (1978). The Urban Origins of Rural Revoluation: Elites and the Masses in Hunan province, China, 1911-1927. Los Angeles: University of California Press.

Melton, J. V. H. (1988). Absolutism and the 18th-century Origins of Compulsory Schooling in Prussia and Austria. Cambridge: Cambridge University Press.

Mitch, D. (2013). The economic history of education. In R. M. Whaples \& R. E.Parker (Eds.), Routledge Handbook of Modern Economic History (pp. 246260). New York: Routledge. 
Mitchener, K. J., \& Yan, S. (forthcoming). Globalization, Trade \& Wages: What Does History tell us about China? . International Economic Review.

Morgan, S., Baten, J., Ma, D., \& Wang, Q. (2009). Evolution of Living Standards and Human Capital in China in 18-20th Century. Explorations in Economic History, 37(3), 347-359.

Musacchio, A., Fritscher, A. C. M., \& Viarengo, M. (2014). Colonial Institutions, Trade Stocks, and the Diffusion of Elementary Education in Brazil, 1889-1930. Journal of Economic History, 74(3), 730-766.

Nehru, V., Swanson, E., \& Dubey, A. (1995). A New Database on Human Capital Stock in Developing and Industrial Countries: Sources, Methodology, and Result. Journal of Development Economics, 46(2), 379-401.

Ni, S., \& Van, P. H. (2006). High Corruption Income in Ming and Qing China. Journal of Development Economics, 81(2), 316-336.

O'Donnell, G. (1996). Another Institutionalization: Latin America and Elsewhere. Kellogg Institute. The Helen Kellogg Institute for International Studies.

Ohkawa, K., \& Rosovsky, H. (1973). Japanese Economic Growth. California: Stanford University Press.

Olson, M. (1993). Dictatorship, democracy, and development. The American Political Science Review, 87(3).

Perkins, D. H. (Ed.). (1975). China's Modern Economy in Historical Perspective: Standford University Press.

Perkins, T. (2002). Village, Market and Well-bing in a Rural Chinsee Township: Routledge.

Psacharopoulos, G. (1981). Returns of Education: an Updated International Comparison. Comparative Education, 17(321-341).

Psacharopoulos, G., \& Patrions, H. A. (2004). Returns to Investment in Education: A Further Update. Education Economics, 12(2).

Qu, T. (2003). Qingdai Difang Zhengfu (Local Government of Qing): Law Press of China.

- Quanguo Chudeng Jiaoyu Tongji (The Statistic Report on Primary Education in 1933). (1937).

- Quanguo Chudeng Jiaoyu Tongji (The statistic report on primary education) (1930).

- Quanguo Chudeng Jiaoyu Tongji (The statistic report on primary education) (1934).

. Quanguo Jiaoyu Jingfei Tongji 1932-1933 (The national educaitonal finance 19321933) (1937).

. Quanguo Jiaoyu Tongji ( The national education statistic report ). (1940).

Ramirez, O, F., \& Boli, J. (1987). The Political Construction of Mass Schooling: European Origins and Worldwide Institutionalization. Sociology of Education, $60(1)$.

Ramirez, F. O., \& Boli, J. (1987). The Political Constrcuction of Mass Schooling: European Origins and Worldwide Institutionalization. Sociology of Education, 60(1), 2-17.

Rankin, M. B., Fairbank, J. K., \& Feuerwerker, A. (1986). Introduction: perspectives on modern China's History. In J. K. Fairbank \& A. Feuerwerker (Eds.), The Cambridge History of China (Vol. 13): Cambridge University Press.

Rawski, E. (1979). Education and Popular Literacy in Ch'ing China. Ann Arbor: The University of Michigan Press.

Rawski, E. (1985). Economy and Social Foundation of Late Imperial Culture. In D. G. Johnson, A. J. Nathan, \& E. S. Rawski (Eds.), Popular Culture in Late Imepiral China: University of California Press. 
Rawski, T. (1975). The Growth of Producer Industries, 1900-1971. In D. H. Perkins (Ed.), China's Modern Economy in Historical Perspective: Standford University Press.

Rawski, T. (1989). Economic Growth in Prewar China. Berkeley,California: University of California Press.

Remick, E. J. (2004). Builidng Local States: China during the Republican and PostMao Era. Massachusetts: Harvard University Asia Centre Press.

Rozman, G. (1973). Urban Networks in Ch'ing China and Tokugawa Japan: Princeton University Press.

Schoppa, R. K. (1982). Chinese Elites and Political Change: Zhejiang Province in the Early Twentieth Century: Harvard University Press.

Schulze, M., \& Fernandes, F. T. (2009). Human capital formation in Austria-Hungary and Germany: time series estimates of educational attainment, 1860-1910 A Felhalmozas Míve: TöRténeti Tanulmányok KöVér GyöRgy Tiszteletére. : Budapest : Századvég.

. Shandongsheng Gexian Difang shibaniandu Jiaoyu Jingfei Suiruiyilanbiao (County balance sheets for education in Shangdong Province across counties, 1929) (1930).

. Shanxisheng Dijiuci Jingji Tongji Zhengji (The eonomic survey of Shanxi Province 9th). (1927).

Shaw, K. W. (1926). Democracy and Finance in China: a Study in the Development of Fiscal Systems and Ideals. New York: Columbia University Press.

Sheridan, J. E. (1977). China in disintegreation: The Republican era in Chinese history, 1912-1949. New York: The Free Press.

Shi, Z. (2009). Qingdai Hubu Yinku Shouzhi He Kucun Tongji ( Statitstics on Income, Expenditure and Stocks of the Board of Revenue Treasury of the Qing Dynasty): Fujian People's Press.

Shih, V., Adolph, C., \& Liu, M. (2012). Getting Ahead in the Communist Party: Explaining the Advancement of Central Committee Members in China. Amercian Political Science Review, 106(01), 166-187.

Shiue, C. H. (2013). Human Capital and Fertility in Chinese Clans Before Modern Growth. NBER Working Paper.

Shu, X. (1928). Jindai Zhongguo Jiaoyu shiliao (A summary of historical materials of the New Education in China). Shanghai: Zhonghua Shuju Press.

Sklar, R. (2004). The Premise of Mixed Government in African Political Studies. In O. Vaughan (Ed.), In Tradition and Politics: Indigenous Political Structures in Africa, : Afirca World Press.

Sng, T.-H. (2014). Size and Dynastic Decline: The Principal-Agent Problem in Late Imperial China 1700-1850, . Explorations in Economic History, 54, 107-127.

Sng, T.-H., \& Moriguchi, C. (2014). Asia's little divergence: state capacity in China and Japan before 1850. Journal of Economic Growth, 19(4), 439-470.

Stauffer. (1922). The Christian occupation of China: A General Survey of the Numerical Strength and Geographical Distribution of the Christian Forces in China. Shanghai: China Continuation Committee.

Sun, Z. (1935). Zhongguo Tianfu wenti (The problem of land tax in China)

. Shanghai: Xinshengming Shujv.

Tao, Z. (Ed.). (1923). Zhongguo Jiaoyu Tongji Gailan (A Summary of Chinese Education Statistics): China Education Improvement Institute.

Tsai, L. (2007). Solidary Groups, Informal Accountability, and Local Public Goods Provision in Rural China. American Political Science Review, 101(2), 355-372. 
Tsurumi, P. (1977). Japanese Colonial Education in Taiwan: Havard University Press. UIS (Producer). (http://www.uis.unesco.org/Education/Pages/default.aspx). Education.

UNESCO. (2000). The right to education: towards education for all throughout life: UNESCO Publishing.

. US Census Bureau Glossary. (2000).

VanderVen, E. (2005). Village-State Cooperation: Modern Community Schools and Their Funding, Haicheng County, Fengtian, 1905-1931. Modern China, 31(2), 204-235. doi: 10.1177/0097700404273985

Ven, E. V. (2005). Village-State cooperation: Modern community schools and their funding, Haicheng County, Fengtian, 1905-1931. Modern China, 31(2).

Wakeman, F., \& Grant, C. (Eds.). (1975). Conflict and Control in Late Imperial China. Los Angeles: University of California Press.

Wang, F. (Ed.). (1994). Minguoshi Dang'an Ziliao Huibian-- Jiaoyu (The collection of archive material for Republic of China -- Education): The second historical archive of China, Phoenix Publishing House.

Wang, J. (Ed.). (1955). Zhonguo Jindai Gongye Shi Ziliao, 1895-1914 (The history of modern industry of China, 1895-1914) (Vol. 2). Beijing: Science Press.

Wang, Q. (2000). Guomindang Zhizhengshiqi Xianzhangde Renshishanti yu Quntijiaose ( A study on county magistrate under the rule of Nationalist Party): Hubei People Press.

Wang, X. (Ed.). (1934). Diyici Jiaoyu Nianjian ( The First Education Report): Education Department Press.

Wang, Y.-c. (1973). Land Taxation in Imperial China, 1750-1911: Harvard University Press.

Wen, Y. (2002). Private School Education in Southern Jiangsu during the 1930s. Yancheng Normal School, 22(4).

West, E. G. (1965). Education and the State: A study in Political Economy: The Institute of Economic Affairs.

Wikisource (Producer). (2013, http://zh.wikisource.org/w/index.php?title=\%E4\%B8\%AD\%E5\%8D\%8E\%E4 \%BA\%BA\%E6\%B0\%91\%E5\%85\%B1\%E5\%92\%8C\%E5\%9B\%BD\%E4\%B 9\%89\%E5\%8A\%A1\%E6\%95\%99\%E8\%82\%B2\%E6\%B3\%95_(1986\%E5\% B9\%B4)\&oldid=397125). The Law on Nine-Year Compulsory Education (中 华人民共和国义务教育法).

Wiseman, J., \& Peacock, A. T. (1962). The growth of public expenditure in the United Kingdom: Princeton University Press

WorldBank. (2004). World Development Report 2004: Making Services Work for Poor People. Washington, DC.: The World Bank.

Wössmann, L. (2000). Specifying Human Capital: A Review, Some Extensions, and Development Effects. Kiel Wokring Paper.

Wößmann, L. (2000). Specifying Human Capital: a Review, Some Extensions, and Development Effects. Kiel Working Papers.

Wou, O. Y. K. (1974). The district magistrate profession in the early Republican period: occupational recruitment, training and mobility. Modern Asian Studies, $8(2), 217-245$.

Wright, T. (Ed.). (1992). The Chinese Economy in the Early 20th Century: Recent Chinese Studeis. New York: St. Martin's Press.

Wu, B. (1947). Zhongguo Guomin Suode ( National Income of China). Shanghai: Zhonghua Shuju. 
Xin, Y. (1932). Di Sibailiushiqici de chuanzhan (The 467th Sichuan War). Eastern Miscellany, 29(4).

$\mathrm{Xu}$, Y. (2009). Wanqing Juanshui Zonglun -- yi1851-1894 Weibeijing (An review on tax items of late Qing). Zhongguo Jingjishi Yanjiu (Reserches in Chinese Economic History), 3(1002-8005).

Xu, Y., Holdvari, P., \& Leeuwen, B. v. (2013). Human Capital in Qing China: Economic Determinism or a History of Failed Opportunities? MPRA Paper University Library of Munich. Munich.

Xu, Y., \& Yao, Y. (2014, Forthcoming). Informal Institutions, Collective Action, and Public Investment in Rural China. American Political Science Review.

Yamada, T. (1987a). The Foundation s and Limits of State Power in Guomindang Ideology-Government, Party and People. In S. R. Schram (Ed.), Foudations and Limits of State Power in China: School of Oriental and African Studies University of London.

Yamada, T. (1987b). Foundations and Limits of State Power in China. In S. R. Schram (Ed.), The Foundation and Limits of State Power in Guomingdang Ideology-Government, Party and People. London: The School of Oriental and African Studies Press.

Yan, S. (2007). Real Wages and Skill Premia in China, 1858 to 1936. (PhD thesis), University of California, Los Angeles.

Yan, Z. (1955). Zhongguo Jindai Jingjishi Tongji Ziliao Xuanji (Selected Statistical Matierals on Modern Chinese Economic History). Beijing: Science Press.

Yang, X. (Ed.). (1934). Diyici Jiaoyu Tongji (The First Chinese Education Yearbook): The Ministry of Education Press.

Young, E. P. (1983). Politics in the aftermath of revolution: the era of Yuan Shih-k'ai, 1912-16 In J. K. Fairbank \& D. Twitchett (Eds.), The Cambridge History of China Volume 12: Republican China, 1912-1949, Part 1 (Vol. 12): Cambridge University Press.

Yuchtman, N., \& Cantoni, D. (2013). The Political Economy of Educational Content and Development: Lessons from History. Journal of Development Economics(104), 233-244.

Zelin, D. (1984). The Magistrate's Tael: University of California Press.

Zelin, M. (1994). Merchant Dispute Mediation in Twentieth-Century Zigong, Sichuan. In K. Bernhardt \& P. C. C. Huang (Eds.), Civil Law in Qing and Republican China: Standford University Press.

Zhang, B., \& Qin, Y. (2001). Jindai Zhejiang de Sishu Gailiang ( Reform of Old-Style Private Schools in Modern Zhejiang). Journal of Zhejiang Univeristy 31(3).

Zhang, X. (2000). Social Transformation in Modern China: The state and Local elites in Henan: Cambridge University Press.

Zhang, Y. (1999). Minguo Shiqi Henansheng Xianzhang Qunti Yanjiu, 1927-1937 (A study on county magistrate in Henan province, 1927-1937). Historical Reserach, 2.

Zhang, Z., \& Ding, Y. (1982). Qingmo Minbian Nianbiao (The History of Civil Conflict of the Late Qing).

Zhong, Y. (2003). Local Government and Politics in China: Challenges from Below: An East Gate Book

. Zhonghua minguo jiaoyu tongji tubiao (The education statistic report for Republic of China, fifth) (1916).

Zhu, J. (Ed.). (1948). Dierci Jiaoyu Nianjian ( The Second Education Report) (Vol. 15). Shanghai Shangwu Press. 


\section{Appendix A:}

Table: Enrolment level by schooling level: from 1900 to 2009

\begin{tabular}{|c|c|c|c|c|}
\hline Year & $\begin{array}{c}\text { Population } \\
\text { (10000 persons) }\end{array}$ & Primary & Secondary & Tertiary \\
\hline 1907 & 41597 & 1198455 & 31682 & 46110 \\
\hline 1908 & 41830 & 1380940 & 36364 & 45258 \\
\hline 1909 & 42064 & 1591210 & 40468 & 44401 \\
\hline 1910 & 42300 & 1833498 & 44345 & 43539 \\
\hline 1911 & 42766 & 2112677 & 48223 & 41836 \\
\hline 1912 & 43238 & 2795475 & 52100 & 40114 \\
\hline 1913 & 43714 & 3485807 & 57980 & 38373 \\
\hline 1914 & 44196 & 3912727 & 67254 & 32079 \\
\hline 1915 & 44683 & 4140066 & 69770 & 25242 \\
\hline 1916 & 45175 & 3843454 & 60924 & 19241 \\
\hline 1917 & 45673 & 4425420 & 89332 & 22207 \\
\hline 1918 & 46177 & 5013815 & 117740 & 25205 \\
\hline 1919 & 46686 & 5608638 & 114151 & 28237 \\
\hline 1920 & 47200 & 6210007 & 110563 & 31301 \\
\hline 1921 & 47367 & 6405554 & 106974 & 32298 \\
\hline 1922 & 47535 & 6601802 & 103385 & 33298 \\
\hline 1923 & 47704 & 6924113 & 112249 & 34302 \\
\hline 1924 & 47873 & 7247571 & 121114 & 35309 \\
\hline 1925 & 48043 & 7572177 & 129978 & 36320 \\
\hline 1926 & 48213 & 7897930 & 149552 & 32825 \\
\hline 1927 & 48384 & 8224831 & 169126 & 29318 \\
\hline 1928 & 48555 & 8552880 & 188700 & 25798 \\
\hline 1929 & 48727 & 8882077 & 248668 & 29123 \\
\hline 1930 & 48900 & 10943979 & 396948 & 37566 \\
\hline 1931 & 49264 & 11720596 & 401772 & 44167 \\
\hline 1932 & 49631 & 12225066 & 409586 & 42710 \\
\hline 1933 & 50000 & 12584479 & 415948 & 42936 \\
\hline 1934 & 50264 & 13188133 & 401449 & 41768 \\
\hline 1935 & 50529 & 15110199 & 438113 & 41128 \\
\hline 1936 & 50796 & 18364956 & 482522 & 41923 \\
\hline 1937 & 51064 & 12847914 & 309563 & 31188 \\
\hline 1938 & 51334 & 12281857 & 409448 & 36180 \\
\hline 1939 & 51605 & 12669976 & 423916 & 44422 \\
\hline 1940 & 51877 & 15545857 & 438384 & 52376 \\
\hline 1941 & 52151 & 15058051 & 452853 & 59457 \\
\hline 1942 & 52426 & 17721105 & 467321 & 64097 \\
\hline 1943 & 52703 & 18602259 & 481789 & 73669 \\
\hline
\end{tabular}




\begin{tabular}{|c|c|c|c|c|}
\hline 1944 & 52981 & 17221814 & 496257 & 78909 \\
\hline 1945 & 53261 & 18655651 & 510726 & 83498 \\
\hline 1946 & 53542 & 20089488 & 525194 & 129336 \\
\hline 1947 & 53824 & 21523326 & 772796 & 155036 \\
\hline 1948 & 54109 & 22957163 & 1020398 & 123495 \\
\hline 1949 & 54167 & 24391000 & 1039000 & 117000 \\
\hline 1950 & 55196 & 28924000 & 1305000 & 137000 \\
\hline 1951 & 56300 & 43154000 & 1568000 & 153000 \\
\hline 1952 & 57482 & 51100000 & 2490000 & 191000 \\
\hline 1953 & 58796 & 51775333 & 3583110 & 223000 \\
\hline 1954 & 60266 & 52450667 & 4073233 & 258800 \\
\hline 1955 & 61465 & 53126000 & 3900000 & 288000 \\
\hline 1956 & 62828 & 58704500 & 5522204 & 349552 \\
\hline 1957 & 64853 & 64283000 & 6281000 & 441000 \\
\hline 1958 & 65994 & 65274200 & 7666919 & 622756 \\
\hline 1959 & 67207 & 66265400 & 8289811 & 815982 \\
\hline 1960 & 66207 & 67256600 & 7776297 & 656686 \\
\hline 1961 & 65859 & 68247800 & 7597595 & 601251 \\
\hline 1962 & 67295 & 69239000 & 7528000 & 830000 \\
\hline 1963 & 69172 & 71575000 & 7616000 & 750000 \\
\hline 1964 & 70499 & 92945000 & 8541000 & 685000 \\
\hline 1965 & 72538 & 116209000 & 9338000 & 674000 \\
\hline 1966 & 74542 & 103417000 & 12498000 & 534000 \\
\hline 1967 & 76368 & 102443000 & 12237000 & 409000 \\
\hline 1968 & 78534 & 100363000 & 13923000 & 259000 \\
\hline 1969 & 80671 & 100668000 & 20215000 & 109000 \\
\hline 1970 & 82992 & 105280000 & 26419000 & 48000 \\
\hline 1971 & 85229 & 112112000 & 31276000 & 83000 \\
\hline 1972 & 87177 & 125492000 & 35825000 & 194000 \\
\hline 1973 & 89211 & 135704000 & 34465000 & 314000 \\
\hline 1974 & 90859 & 144814000 & 36503000 & 430000 \\
\hline 1975 & 92420 & 150941000 & 44661000 & 501000 \\
\hline 1976 & 93717 & 150055000 & 58365000 & 565000 \\
\hline 1977 & 94974 & 146176000 & 67799000 & 625000 \\
\hline 1978 & 96259 & 146240000 & 65483000 & 856000 \\
\hline 1979 & 97542 & 146629000 & 59050000 & 1020000 \\
\hline 1980 & 98705 & 146270000 & 55081000 & 1144000 \\
\hline 1981 & 100072 & 143328000 & 48596000 & 1279000 \\
\hline 1982 & 101654 & 139720000 & 45285000 & 1154000 \\
\hline 1983 & 103008 & 135780000 & 43978000 & 1207000 \\
\hline 1984 & 104357 & 135571000 & 45542000 & 1396000 \\
\hline 1985 & 105851 & 133702000 & 47060000 & 1703000 \\
\hline 1986 & 107507 & 131825000 & 48899000 & 1880000 \\
\hline 1987 & 109300 & 128359000 & 49481000 & 1959000 \\
\hline 1988 & 111026 & 125358000 & 47615000 & 2066000 \\
\hline 1989 & 112704 & 123731000 & 45540000 & 2082000 \\
\hline
\end{tabular}




\begin{tabular}{|r|r|r|r|r|}
1990 & 114333 & 122414000 & 45860000 & 2063000 \\
\hline 1991 & 115823 & 121642000 & 46835000 & 2044000 \\
\hline 1992 & 117171 & 122013000 & 47708000 & 2184000 \\
\hline 1993 & 118517 & 124212000 & 47391000 & 2536000 \\
\hline 1994 & 119850 & 128226000 & 49817000 & 2799000 \\
\hline 1995 & 121121 & 131952000 & 53710000 & 2906000 \\
\hline 1996 & 123626 & 136150000 & 57397000 & 3021000 \\
\hline 1997 & 124761 & 139954000 & 60179000 & 3174000 \\
\hline 1998 & 125786 & 139538000 & 63010000 & 3409000 \\
\hline 1999 & 126743 & 135480000 & 67713000 & 4134000 \\
\hline 2000 & 127627 & 130132500 & 73689100 & 5560900 \\
\hline
\end{tabular}




\section{Appendix B:}

Table: List of county gazetteers for county magistrate's turnover

\begin{tabular}{|c|c|c|c|c|c|}
\hline province & county & county_ch & province & county & county_ch \\
\hline Anhui & Susong Xian & 宿松县 & Fujian & Lianjiang & 连江县 \\
\hline Anhui & Taihu Xian & 太湖县 & Fujian & Luoyuan Xian & 罗源县 \\
\hline Anhui & Tongcheng & 桐城县 & Fujian & Min Xian & 闽县 \\
\hline Anhui & Wangjiang & 望江县 & Fujian & Minqing Xian & 闽清县 \\
\hline Anhui & Dongliu Xian & 东流县 & Fujian & Jian'an Xian & 建安县 \\
\hline Anhui & Guichi Xian & 贵池县 & Fujian & Pucheng Xian & 浦城县 \\
\hline Anhui & Qingyang & 青阳县 & Fujian & Songxi Xian & 松溪县 \\
\hline Anhui & Quanjiao Xian & 全椒县 & Fujian & Zhenghe Xian & 政和县 \\
\hline Anhui & Fengtai Xian & 凤台县 & Fujian & Zhangping & 漳平县 \\
\hline Anhui & Fengyang & 凤阳县 & Fujian & Anxi Xian & 安溪县 \\
\hline Anhui & Shou Zhou & 寿州 & Fujian & Guangze Xian & 光泽县 \\
\hline Anhui & Su Zhou & 宿州 & Fujian & Taining Xian & 泰宁县 \\
\hline Anhui & Guangde & 广德州 & Fujian & Changting & 长汀县 \\
\hline Anhui & Hanshan Xian & 含山县 & Fujian & Guihua Xian & 归化县 \\
\hline Anhui & He Zhou & 和州 & Fujian & Liancheng & 连城县 \\
\hline Anhui & Xi Xian & 歌县 & Fujian & Qingliu Xian & 清流县 \\
\hline Anhui & Xiuning Xian & 休宁县 & Fujian & Shanghang & 上杭县 \\
\hline Anhui & Yi Xian & 黟县 & Fujian & Wuping Xian & 武平县 \\
\hline Anhui & Huoshan Xian & 霍山县 & Fujian & Yongding & 永定县 \\
\hline Anhui & Lujiang Xian & 庐江县 & Fujian & Putian Xian & 莆田县 \\
\hline Anhui & Shucheng & 舒城县 & Fujian & Xianyou Xian & 仙游县 \\
\hline Anhui & Wuwei Zhou & 无为州 & Fujian & Jianle Xian & 将乐县 \\
\hline Anhui & Jing Xian & 泾县 & Fujian & Nanping Xian & 南平县 \\
\hline Anhui & Nanling Xian & 南陵县 & Fujian & Sha Xian & 沙县 \\
\hline Anhui & Xuancheng & 宣城县 & Fujian & Shunchang & 顺昌县 \\
\hline Anhui & Si Zhou & 泗州 & Fujian & Yong'an Xian & 永安县 \\
\hline Anhui & Tianchang & 天长县 & Fujian & Youxi Xian & 尤溪县 \\
\hline Anhui & Dangtu Xian & 当涂县 & Fujian & Datian Xian & 大田县 \\
\hline Anhui & Fanchang & 繁昌县 & Fujian & Dehua Xian & 德化县 \\
\hline Anhui & Wuhu Xian & 芜湖县 & Fujian & Yongchun & 永春州 \\
\hline Anhui & Bo Zhou & 毫州 & Fujian & Haicheng & 海澄县 \\
\hline Anhui & Fuyang Xian & 阜阳县 & Fujian & Longxi Xian & 龙溪县 \\
\hline Anhui & Huoqiu Xian & 霍丘县 & Fujian & Zhangpu Xian & 漳浦县 \\
\hline Anhui & Taihe Xian & 太和县 & Fujian & Zhao'an Xian & 诏安县 \\
\hline Anhui & Woyang Xian & 涡阳县 & Fujian & Nanjing Xian & 南靖县 \\
\hline Anhui & Jianping Xian & 建平县 & Fujian & Houguan & 侯官县 \\
\hline Fujian & Fu'an Xian & 福安县 & Fujian & Ninghua Xian & 宁化县 \\
\hline Fujian & Fuding Xian & 福鼎县 & Fujian & Nan'an Xian & 南安县 \\
\hline Fujian & Ningde Xian & 宁德县 & Fujian & Tong'an Xian & 同安县 \\
\hline Fujian & Changle Xian & 长乐县 & Fujian & Yongfu Xian & 永福县 \\
\hline
\end{tabular}




\begin{tabular}{|c|c|c|c|c|c|}
\hline Fujian & Fuqing Xian & 福清县 & Fujian & Jian'ou Xian & 建安县 \\
\hline Fujian & Gutian Xian & 古田县 & Fujian & Zhao'an Xian & 诏安县 \\
\hline Fujian & Yunxiao Ting & 云霄厅 & Guizhou & Puding Xian & 普定县 \\
\hline Fujian & Pingtan Xian & 平潭县 & Guizhou & Qianxi Zhou & 黔西州 \\
\hline Guangdong & Chaoyang & 潮阳县 & Guizhou & Taigong Ting & 台拱厅 \\
\hline Guangdong & Dapu Xian & 大埔县 & Guizhou & Qingping & 清平县 \\
\hline Guangdong & Huaxian Xian & 花县 & Guizhou & Qingxi Xian & 青溪县 \\
\hline Guangdong & Longmen & 龙门县 & Guizhou & Qingzhen & 清镇县 \\
\hline Guangdong & Qingyuan & 清远县 & Guizhou & Renhuai Xian & 仁怀县 \\
\hline Guangdong & Xiangshan & 香山县 & Guizhou & Shibing Xian & 施秉县 \\
\hline Guangdong & Xinhui Xian & 新会县 & Guizhou & Shiqian Fu & 石阶府 \\
\hline Guangdong & Boluo Xian & 博罗县 & Guizhou & Shuicheng & 水城厅 \\
\hline Guangdong & Haifeng Xian & 海丰县 & Guizhou & Si'nan Fu & 思南府 \\
\hline Guangdong & Heping Xian & 和平县 & Guizhou & Sizhou Fu & 思州府 \\
\hline Guangdong & Dan Zhou & 儋州 & Guizhou & Suiyang Xian & 绥阳县 \\
\hline Guangdong & Gan'en Xian & 感恩县 & Henan & Shenqiu Xian & 沈丘县 \\
\hline Guangdong & Lechang Xian & 乐昌县 & Henan & Taikang Xian & 太康县 \\
\hline Guangdong & Renhua Xian & 仁化县 & Henan & Guang Zhou & 光州 \\
\hline Guangdong & Wengyuan & 翁源县 & Henan & Guangshan & 光山县 \\
\hline Guangdong & Deqing Zhou & 德庆州 & Henan & Shangcheng & 商城县 \\
\hline Guangdong & Enping Xian & 恩平县 & Henan & Cheng Xian & 柘城县 \\
\hline Guangdong & Gaoyao Xian & 高要县 & Henan & Luyi Xian & 鹿邑县 \\
\hline Guangdong & Kaiping Xian & 开平县 & Henan & Xiayi Xian & 夏邑县 \\
\hline Guangdong & Yangshan & 阳山县 & Henan & Yucheng & 虞城县 \\
\hline Guangdong & Xining Xian & 西宁县 & Henan & Mengjin Xian & 孟津县 \\
\hline Guangdong & Sanshui Xian & 三水县 & Henan & Henei Xian & 河内县 \\
\hline Guangdong & Hui Zhou & 归善县 & Henan & Wuzhi Xian & 武陟县 \\
\hline Guangdong & Hua Xian & 花县 & Henan & Weishi Xian & 尉氏县 \\
\hline Guangdong & Chixi Xian & 赤溪县 & Henan & Zhongmou & 中牟县 \\
\hline Guangdong & Nan'ao Ting & 南澳厅 & Henan & Nanzhao Xian & 南召县 \\
\hline Guizhou & Xingyi Xian & 兴义县 & Henan & Tongbai Xian & 桐柏县 \\
\hline Guizhou & Shiqian Fu & 石阶府 & Henan & Ruyang Xian & 汝阳县 \\
\hline Guizhou & Leishan Xian & 丹江厅 & Henan & Shangcai & 上蔡县 \\
\hline Guizhou & Nanlong Xian & 兴义县 & Henan & Suiping Xian & 遂平县 \\
\hline Guizhou & Shuicheng & 水城厅 & Henan & Xincai Xian & 新蔡县 \\
\hline Guizhou & Ziyun Xian & 归化厅 & Henan & Fengqiu Xian & 封丘县 \\
\hline Guizhou & Liping Xian & 黎平府 & Henan & Hua Xian & 滑县 \\
\hline Guizhou & Guanling Xian & 永宁州 & Henan & Jun Xian & 浚县 \\
\hline Guizhou & Jianhe Xian & 清江厅 & Henan & Yancheng & 㰽城县 \\
\hline Guizhou & Zhenfeng & 贞丰州 & Henan & Ruyang Xian & 汝阳县 \\
\hline Guizhou & Huishui Xian & 定香州 & Henan & Guang Zhou & 光州 \\
\hline Guizhou & Majiang Xian & 麻哈州 & Henan & Henei Xian & 河内县 \\
\hline Guizhou & Dujiang Xian & 都江厅 & Henan & Ruicheng & 虞城县 \\
\hline Guizhou & Xifeng Xian & 修文县 & Henan & Yanling Xian & 鄢陵县 \\
\hline Hubei & Jingshan Xian & 京山县 & Hubei & Laifeng Xian & 来凤县 \\
\hline Hubei & Yingcheng & 应城县 & Hubei & Donghu Xian & 东湖县 \\
\hline Hubei & Yingshan & 应山县 & Hubei & Gucheng & 谷城县 \\
\hline Hubei & Yunmeng & 云梦县 & Hubei & Jiangxia Xian & 江夏县 \\
\hline Hubei & Hanchuan & 汉川县 & Hubei & Huanggang & 黄冈县 \\
\hline
\end{tabular}




\begin{tabular}{|c|c|c|c|c|c|}
\hline Hubei & Hanyang Xian & 汉阳县 & Hubei & Changle Xian & 长乐县 \\
\hline Hubei & Huangpi Xian & 黄陂县 & Hubei & Huangma & 黄安县 \\
\hline Hubei & Guangji Xian & 广济县 & Hubei & Hefeng Xian & 鹤峰州 \\
\hline Hubei & Huang'an & 黄安县 & Hubei & Hanyang xian & 汉阳县 \\
\hline Hubei & Luotian Xian & 罗田县 & Hubei & Zigui Xian & 归州 \\
\hline Hubei & Macheng Xian & 麻城县 & Hunan & Anren Xian & 安仁县 \\
\hline Hubei & Dangyang & 当阳县 & Jiangsu & Jingjiang & 靖江县 \\
\hline Hubei & Yuan'an Xian & 远安县 & Jiangsu & Funing Xian & 阜宁县 \\
\hline Hubei & Jiangling Xian & 江陵县 & Jiangsu & Jurong Xian & 句容县 \\
\hline Hubei & Jianli Xian & 监利县 & Jiangsu & Liuhe Xian & 六合县 \\
\hline Hubei & Shishou Xian & 石首县 & Jiangsu & Chuansha & 川沙厅 \\
\hline Hubei & Songzi Xian & 松滋县 & Jiangsu & Fengxian & 奉贤县 \\
\hline Hubei & Yidu Xian & 宜都县 & Jiangsu & Jinshan Xian & 金山县 \\
\hline Hubei & Jianshi Xian & 建始县 & Jiangsu & Lou Xian & 娄县 \\
\hline Hubei & Lichuan Xian & 利川县 & Jiangsu & Nanhui Xian & 南汇县 \\
\hline Hubei & Xianfeng Xian & 咸丰县 & Jiangsu & Qingpu Xian & 青浦县 \\
\hline Hubei & Chongyang & 崇阳县 & Jiangsu & Zhaowen & 昭文县 \\
\hline Hubei & Jiayu Xian & 嘉鱼县 & Jiangsu & Baoshan Xian & 宝山县 \\
\hline Hubei & Puqi Xian & 蒲圻县 & Jiangsu & Chongming & 崇明县 \\
\hline Hubei & Tongcheng & 通城县 & Jiangsu & Jiading Xian & 嘉定县 \\
\hline Hubei & Tongshan & 通山县 & Jiangsu & Rugao Xian & 如臬县 \\
\hline Hubei & Xingguo Zhou & 兴国州 & Jiangsu & Pei Xian & 沛县 \\
\hline Hubei & Nanzhang & 南漳县 & Jiangsu & Pi Zhou & 䂙州 \\
\hline Hubei & Xiangyang & 襄阳县 & Jiangsu & Xiao Xian & 萧县 \\
\hline Hubei & Yicheng Xian & 宜城县 & Jiangsu & Tai Zhou & 泰州 \\
\hline Hubei & Zaoyang Xian & 柊阳县 & Jiangsu & Dantu Xian & 丹徒县 \\
\hline Hubei & Changle Xian & 长乐县 & Jiangsu & Lishui Xian & 溧水县 \\
\hline Hubei & Changyang & 长阳县 & Jiangsu & Zhaowen & 昭文县 \\
\hline Hubei & Donghu Xian & 东湖县 & Jiangsu & Lou Xian & 娄县 \\
\hline Hubei & Baokang Xian & 保康县 & Jiangxi & Leping Xian & 乐平县 \\
\hline Hubei & Fang Xian & 房县 & Shaanxi & Changwu & 长武县 \\
\hline Hubei & Yun Xian & 郧县 & Shaanxi & Chunhua & 淳化县 \\
\hline Hubei & Yunxi Xian & 郧西县 & Shaanxi & Sanshui Xian & 三水县 \\
\hline Hubei & Zhushan Xian & 竹山县 & Shaanxi & Baoji Xian & 宝鸡县 \\
\hline Hubei & Zhuxi Xian & 竹溪县 & Shaanxi & Fufeng Xian & 扶风县 \\
\hline Hubei & Xuan'en Xian & 宣恩县 & Shaanxi & Linyou Xian & 麟游县 \\
\hline Hubei & Xingguo Zhou & 兴国州 & Shaanxi & Long Zhou & 陇州 \\
\hline Shaanxi & Mei Xian & 腒县 & Shaanxi & Baihe Xian & 白河县 \\
\hline Shaanxi & Qishan Xian & 岐山县 & Shaanxi & Hanyin Ting & 汉阴厅 \\
\hline Shaanxi & Fu Zhou & 鹿州 & Shaanxi & Shiquan Xian & 石泉县 \\
\hline Shaanxi & Zhongbu Xian & 中部县 & Shaanxi & Xunyang & 洵阳县 \\
\hline Shaanxi & Chenggu Xian & 城固县 & Shaanxi & Anding Xian & 安定县 \\
\hline Shaanxi & Dingyuan & 定远厅 & Shaanxi & Ansai Xian & 安塞县 \\
\hline Shaanxi & Feng Xian & 凤县 & Shaanxi & Ganquan & 甘泉县 \\
\hline Shaanxi & Fuoping Ting & 佛坪厅 & Shaanxi & Jingbian Xian & 靖边县 \\
\hline Shaanxi & Nanzheng & 南郑县 & Shaanxi & Yanchang & 延长县 \\
\hline Shaanxi & Xixiang Xian & 西乡县 & Shaanxi & Yanchuan & 延川县 \\
\hline Shaanxi & Yang Xian & 洋县 & Shaanxi & Fugu Xian & 府谷县 \\
\hline Shaanxi & Qian Zhou & 乾州 & Shaanxi & Huaiyuan & 怀远县 \\
\hline
\end{tabular}




\begin{tabular}{|c|c|c|c|c|c|}
\hline Shaanxi & Wugong Xian & 武功县 & Shaanxi & Jia Zhou & 澱州 \\
\hline Shaanxi & Shang Zhou & 商州 & Shaanxi & Shenmu Xian & 神木县 \\
\hline Shaanxi & Shangnan & 商南县 & Shaanxi & Yulin Xian & 榆林县 \\
\hline Shaanxi & Shanyang & 山阳县 & Shaanxi & Luonan Xian & 洛南县 \\
\hline Shaanxi & Zhen'an Xian & 镇安县 & Shaanxi & Huaiyuan & 怀远县 \\
\hline Shaanxi & Mizhi Xian & 米脂县 & Shaanxi & Bao'an Xian & 保安县 \\
\hline Shaanxi & Suide Zhou & 绥德州 & Shaanxi & Xianning & 咸宁县 \\
\hline Shaanxi & Wubao Xian & 吴堡县 & Shaanxi & Yao Zhou & 耀州 \\
\hline Shaanxi & Baishui Xian & 白水县 & Shaanxi & Zhongbu & 中部县 \\
\hline Shaanxi & Chengcheng & 澄城县 & Shaanxi & Qianyang & 汧阳县 \\
\hline Shaanxi & Dali Xian & 大荔县 & Shaanxi & Liuba Ting & 留坝厅 \\
\hline Shaanxi & Hancheng & 韩城县 & Shaanxi & Ningshan & 宁陕厅 \\
\hline Shaanxi & Heyang Xian & 邻阳县 & Shaanxi & Xiaoyi Ting & 孝义厅 \\
\hline Shaanxi & Hua Zhou & 华州 & Shaanxi & Bin Zhou & 邠州 \\
\hline Shaanxi & Huayin Xian & 华阴县 & Shaanxi & Dingyuan & 定远厅 \\
\hline Shaanxi & Pucheng Xian & 蒲城县 & Shaanxi & Lan'ao Xian & 蓝田县 \\
\hline Shaanxi & Jingyang Xian & 泾阳县 & Shaanxi & Bin Xian & 邠州 \\
\hline Shaanxi & Lantian Xian & 蓝田县 & Shaanxi & Ningqiang & 宁芫州 \\
\hline Shaanxi & Lintong Xian & 临潼县 & Shandong & Cao Xian & 曹县 \\
\hline Shaanxi & Ningshan & 宁陕厅 & Shandong & Juye Xian & 巨野县 \\
\hline Shaanxi & Tongguan & 同官县 & Shandong & Huang Xian & 黄县 \\
\hline Shaanxi & Weinan Xian & 渭南县 & Shandong & Ninghai Zhou & 宁海州 \\
\hline Shaanxi & Xianning Xian & 咸宁县 & Shandong & Penglai Xian & 蓬莱县 \\
\hline Shaanxi & Xianyang & 咸阳县 & Shandong & Chiping Xian & 茌平县 \\
\hline Shaanxi & Xiaoyi Ting & 孝义厅 & Shandong & Guan Xian & 冠县 \\
\hline Shaanxi & Xingping & 兴平县 & Shandong & Guantao Xian & 馆陶县 \\
\hline Shaanxi & Yao Zhou & 耀州 & Shandong & Qingping & 清平县 \\
\hline Shaanxi & Zhouzhi Xian & 盆厔县 & Shandong & Gaomi Xian & 高密县 \\
\hline Shaanxi & Ankang Xian & 安康县 & Shandong & Changqing & 长清县 \\
\hline Shandong & Jiyang Xian & 济阳县 & Shanxi & Changzi Xian & 长子县 \\
\hline Shandong & Licheng Xian & 历城县 & Shanxi & Changzi Xian & 长子县 \\
\hline Shandong & Xincheng & 新城县 & Shanxi & Dingxiang & 定襄县 \\
\hline Shandong & Zhangqiu & 章丘县 & Shanxi & Fenxi Xian & 汾西县 \\
\hline Shandong & Zichuan Xian & 淄川县 & Shanxi & Fenyang Xian & 汾阳县 \\
\hline Shandong & Jining Zhou & 济宁州 & Shanxi & Gaoping Xian & 高平县 \\
\hline Shandong & Xiajin Xian & 夏津县 & Shanxi & Guangling & 广灵县 \\
\hline Shandong & Boshan Xian & 博山县 & Shanxi & Guo Xian & 崞县 \\
\hline Shandong & Changle Xian & 昌乐县 & Shanxi & Hejin Xian & 河津县 \\
\hline Shandong & Shouguang & 寿光县 & Shanxi & Hequ Xian & 河曲县 \\
\hline Shandong & Pingyin Xian & 平阴县 & Shanxi & Heshun Xian & 和顺县 \\
\hline Shandong & Tai'an Xian & 泰安县 & Shanxi & Hongdong & 洪洞县 \\
\hline Shandong & Haifeng Xian & 海丰县 & Shanxi & Hongdong & 洪洞县 \\
\hline Shandong & Huimin Xian & 惠民县 & Shanxi & Huairen Xian & 怀仁县 \\
\hline Shandong & Qingcheng & 青城县 & Shanxi & Huguan Xian & 壶关县 \\
\hline Shandong & Shanghe Xian & 商河县 & Shanxi & Hunyuan & 浑源州 \\
\hline Shandong & Yangxin Xian & 阳信县 & Shanxi & Huo Zhou & 霍州 \\
\hline Shandong & Zhanhua Xian & 露化县 & Shanxi & Ji Zhou & 吉州 \\
\hline Shandong & Qufu Xian & 曲阜县 & Shanxi & Jiang Xian & 㖓县 \\
\hline Shandong & Yishui Xian & 沂水县 & Shanxi & Jiang Zhou & 绛州 \\
\hline
\end{tabular}




\begin{tabular}{|c|c|c|c|c|c|}
\hline Shandong & Le'an Xian & 乐安县 & Shanxi & Jiaocheng & 交城县 \\
\hline Shandong & Ninghai Zhou & 宁海州 & Shanxi & Jie Zhou & 解州 \\
\hline Shandong & Xincheng & 新城县 & Shanxi & Jiexiu Xian & 介休县 \\
\hline Shandong & Haiyang Xian & 海阳县 & Shanxi & Jingle Xian & 静乐县 \\
\hline Shandong & Le'an Xian & 乐安县 & Shanxi & Jishan Xian & 稷山县 \\
\hline Shandong & Fan Xian & 范县 & Shanxi & Kelan Zhou & 岢岗州 \\
\hline Shandong & Zhanhua Xian & 霑化县 & Shanxi & Lan Xian & 岗县 \\
\hline Shandong & Wuli Xian & 海丰县 & Shanxi & Liao Zhou & 辽州 \\
\hline Shandong & Linqu Xian & 临邑县 & Shanxi & Licheng Xian & 黎城县 \\
\hline Shandong & Renping Xian & 茌平县 & Shanxi & Lin Xian & 临县 \\
\hline Zhejiang & Anji Xian & 安吉县 & Shanxi & Linfen Xian & 临汾县 \\
\hline Zhejiang & Deqing Xian & 德清县 & Shanxi & Lingchuan & 陵川县 \\
\hline Zhejiang & Yongkang & 永康县 & Shanxi & Lingqiu Xian & 灵丘县 \\
\hline Zhejiang & Fenghua Xian & 奉化县 & Shanxi & Lingshi Xian & 灵石县 \\
\hline Zhejiang & Qin Xian & 鄞县 & Shanxi & Linjin Xian & 临晋县 \\
\hline Zhejiang & Changshan & 常山县 & Shanxi & Lucheng Xian & 潞城县 \\
\hline Zhejiang & Jiangshan & 江山县 & Shanxi & Ningwu Xian & 宁武县 \\
\hline Zhejiang & Shangyu Xian & 上虞县 & Shanxi & Ningxiang & 宁乡县 \\
\hline Zhejiang & Sheng Xian & 嵊县 & Shanxi & Pianguan & 偏关县 \\
\hline Zhejiang & Xinchang & 新昌县 & Shanxi & Pingding & 平定州 \\
\hline Zhejiang & Xianju Xian & 仙居县 & Shanxi & Pinglu Xian & 平鲁县 \\
\hline Shanxi & Anyi Xian & 安邑县 & Shanxi & Pinglu Xian & 平陆县 \\
\hline Shanxi & Pingyao Xian & 平遥县 & Shanxi & Yongning & 永宁州 \\
\hline Shanxi & $\mathrm{Pu}$ Xian & 蒲县 & Shanxi & Youyu Xian & 右玉县 \\
\hline Shanxi & Qi Xian & 祁县 & Shanxi & Yu Xian & 孟县 \\
\hline Shanxi & Qin Zhou & 沁州 & Zhili & Qingyuan & 清苑县 \\
\hline Shanxi & Qinshui Xian & 沁水县 & Zhili & Dongming & 东明县 \\
\hline Shanxi & Qinyuan Xian & 沁源县 & Zhili & Hejian Xian & 河间县 \\
\hline Shanxi & Quwo Xian & 曲沃县 & Zhili & Jiaohe Xian & 交河县 \\
\hline Shanxi & Ronghe Xian & 荣河县 & Zhili & Jing Zhou & 景州 \\
\hline Shanxi & Ruicheng & 芮城县 & Zhili & Wuqiao Xian & 吴桥县 \\
\hline Shanxi & Ruicheng & 芮城县 & Zhili & Xian Xian & 献县 \\
\hline Shanxi & Shanyin Xian & 山阴县 & Zhili & Wuyi Xian & 武邑县 \\
\hline Shanxi & Shenchi Xian & 神池县 & Zhili & Xingtai Xian & 邢台县 \\
\hline Shanxi & Shilou Xian & 石楼县 & Zhili & Ba Zhou & 霸州 \\
\hline Shanxi & Shouyang & 寿阳县 & Zhili & Sanhe Xian & 三河县 \\
\hline Shanxi & Shuo Zhou & 朔州 & Zhili & Cang Zhou & 沧州 \\
\hline Shanxi & Taiping Xian & 太平县 & Zhili & Nanpi Xian & 南皮县 \\
\hline Shanxi & Taiyuan Xian & 太原县 & Zhili & Yanshan Xian & 盐山县 \\
\hline Shanxi & Tianzhen Xian & 天镇县 & Zhili & Chicheng & 赤城县 \\
\hline Shanxi & Tunliu Xian & 屯留县 & Zhili & Wanquan & 万全县 \\
\hline Shanxi & Wanquan & 万泉县 & Zhili & Funing Xian & 抚宁县 \\
\hline Shanxi & Wenshui Xian & 文水县 & Zhili & Jingxing Xian & 井陉县 \\
\hline Shanxi & Wenxi Xian & 闻喜县 & Zhili & Yutian Xian & 玉田县 \\
\hline Shanxi & Wutai Xian & 五台县 & Zhili & Dongming & 东明县 \\
\hline Shanxi & Wuxiang Xian & 武乡县 & Zhili & Xian Xian & 献县 \\
\hline Shanxi & Wuzhai Xian & 五寨县 & Zhili & Ding Zhou & 定州 \\
\hline Shanxi & Xi Zhou & 隰州 & Zhili & Jingxing Xian & 井陉县 \\
\hline Shanxi & Xia Xian & 夏县 & Zhili & Xingtang & 行唐县 \\
\hline
\end{tabular}




\begin{tabular}{|c|c|c|c|c|c|}
\hline Shanxi & Xiangling & 襄陵县 & Zhili & Longguan & 龙门县 \\
\hline Shanxi & Xiangning & 乡宁县 & Zhili & Ding Zhou & 定州 \\
\hline Shanxi & Xiangyuan & 襄垣县 & Zhili & Dingxing & 定兴县 \\
\hline Shanxi & Xiaoyi Xian & 孝义县 & Zhili & Dong'an Xian & 东安县 \\
\hline Shanxi & Xing Xian & 兴县 & Zhili & Dongguang & 东光县 \\
\hline Shanxi & Xugou Xian & 徐沟县 & Zhili & Dongming & 东明县 \\
\hline Shanxi & Yangcheng & 阳城县 & Zhili & Fangshan & 房山县 \\
\hline Shanxi & Yanggao Xian & 阳高县 & Zhili & Feixiang Xian & 肥乡县 \\
\hline Shanxi & Yangqu Xian & 阳曲县 & Zhili & Fengning & 丰宁县 \\
\hline Shanxi & Yi Zhou & 沂州 & Zhili & Fengrun Xian & 丰润县 \\
\hline Shanxi & Yicheng Xian & 翼城县 & Zhili & Fengshui & 风水禁地 \\
\hline Shanxi & Ying Zhou & 应州 & Zhili & Fucheng Xian & 卢城县 \\
\hline Shanxi & Yishi Xian & 猗氏县 & Zhili & Funing Xian & 抚宁县 \\
\hline Shanxi & Yonghe Xian & 永和县 & Zhili & Fuping Xian & 阜平县 \\
\hline Shanxi & Yongji Xian & 永济县 & Zhili & Fuxin Xian & 卢新县 \\
\hline Zhili & Gaocheng & 蒠城县 & Zhili & Hengshui & 衡水县 \\
\hline Zhili & Gaoyang Xian & 高阳县 & Zhili & Huai'an Xian & 怀安县 \\
\hline Zhili & Gaoyi Xian & 高邑县 & Zhili & Huailai Xian & 怀来县 \\
\hline Zhili & Gu'an Xian & 固安县 & Zhili & Huairou Xian & 怀柔县 \\
\hline Zhili & Guangchang & 广昌县 & Zhili & Huolu Xian & 获鹿县 \\
\hline Zhili & Guangping & 广平县 & Zhili & Ji Zhou & 冀州 \\
\hline Zhili & Guangzong & 广宗县 & Zhili & Ji Zhou & 蓟州 \\
\hline Zhili & Gucheng Xian & 故城县 & Zhili & Jianchang & 建昌县 \\
\hline Zhili & Handan Xian & 邯郸县 & Zhili & Jianping Xian & 建平县 \\
\hline Zhili & Hangtang & 行唐县 & Zhili & Jiaohe Xian & 交河县 \\
\hline Zhili & Hejian Xian & 河间县 & Zhili & Jin Zhou & 晋州 \\
\hline & & & Zhili & Jing Zhou & 景州 \\
\hline
\end{tabular}

*Note: all the gazetteers are gathered from Bodleian Book Storage Facility in Swindon, Oxford university 


\section{Appendix C:}

Sample page for The Imperially Established Institutes and Laws of the Great Qing Dynasty (大清会典)

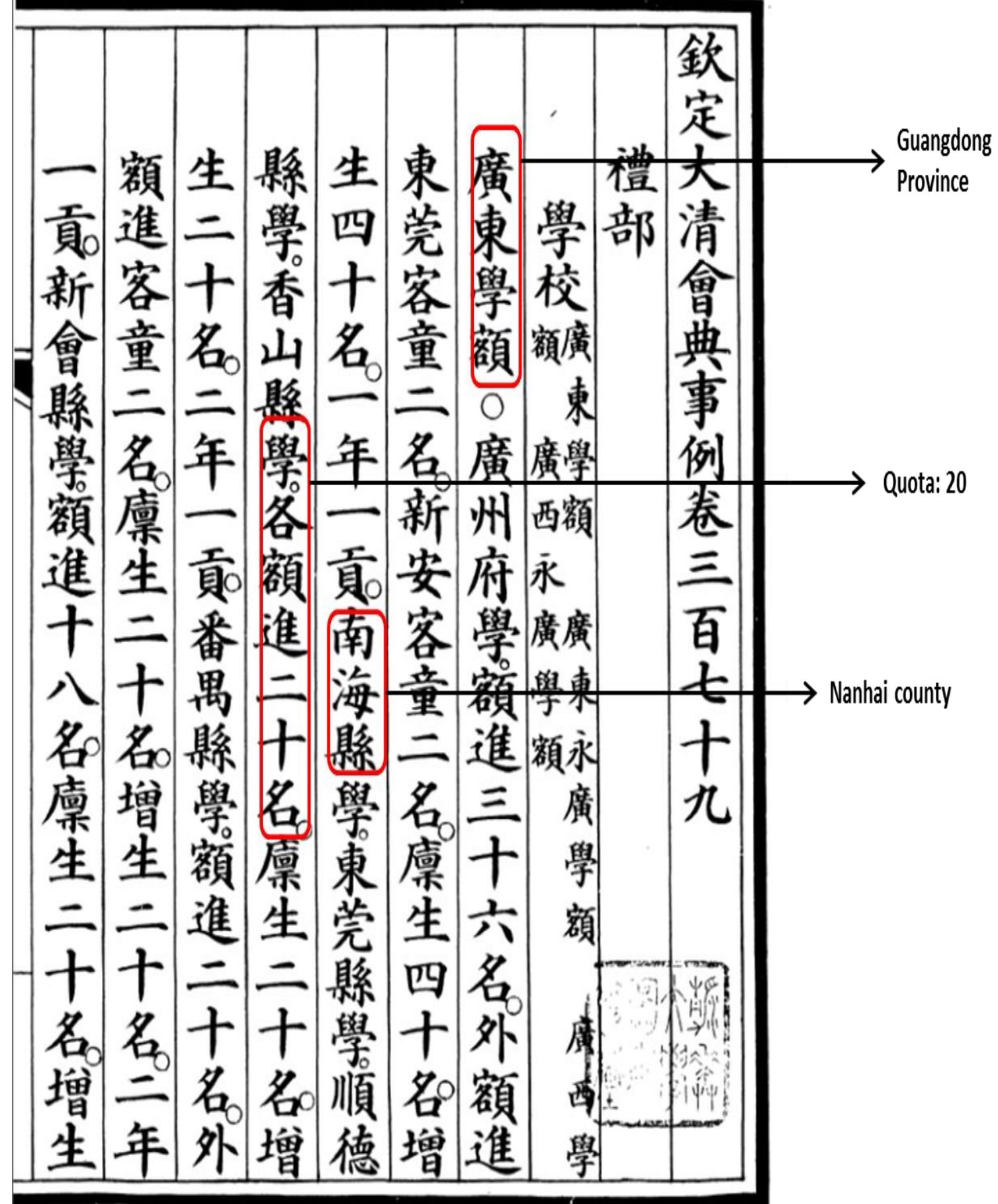

